\title{
From Social Reform to Neoliberalism: Islamization, State Formation and Gender Formation in Pakistan, 1850-1988
}

\author{
by
}

Fauzia Gardezi

A thesis submitted to the Faculty of Graduate and Postdoctoral Affairs in partial fulfillment of the requirements for the degree of

Doctor of Philosophy

Department of Sociology and Anthropology

Carleton University

Ottawa, Ontario

(C) 2011, Fauzia Gardezi 
Library and Archives

Canada

Published Heritage

Branch

395 Wellington Street

Ottawa ON K1A ON4

Canada
Bibliothèque et

Archives Canada

Direction du

Patrimoine de l'édition

395 , rue Wellington

Ottawa ON K1A ON4

Canada
Your file Votre référence

ISBN: 978-0-494-81572-4

Our file Notre référence

ISBN: 978-0-494-81572-4
NOTICE:

The author has granted a nonexclusive license allowing Library and Archives Canada to reproduce, publish, archive, preserve, conserve, communicate to the public by telecommunication or on the Internet, loan, distribute and sell theses worldwide, for commercial or noncommercial purposes, in microform, paper, electronic and/or any other formats.

The author retains copyright ownership and moral rights in this thesis. Neither the thesis nor substantial extracts from it may be printed or otherwise reproduced without the author's permission.
AVIS:

L'auteur a accordé une licence non exclusive permettant à la Bibliothèque et Archives Canada de reproduire, publier, archiver, sauvegarder, conserver, transmettre au public par télécommunication ou par l'Internet, prêter, distribuer et vendre des thèses partout dans le monde, à des fins commerciales ou autres, sur support microforme, papier, électronique et/ou autres formats.

L'auteur conserve la propriété du droit d'auteur et des droits moraux qui protège cette thèse. $\mathrm{Ni}$ la thèse ni des extraits substantiels de celle-ci ne doivent être imprimés ou autrement reproduits sans son autorisation.
In compliance with the Canadian Privacy Act some supporting forms may have been removed from this thesis.

While these forms may be included in the document page count, their removal does not represent any loss of content from the thesis.
Conformément à la loi canadienne sur la protection de la vie privée, quelques formulaires secondaires ont été enlevés de cette thèse.

Bien que ces formulaires aient inclus dans la pagination, il n'y aura aucun contenu manquant. 


\begin{abstract}
Beginning in 1977, the military regime of General Zia-ul-Haq proclaimed a mission to "Islamize" Pakistan. Much of the Islamization program pursued for the next eleven years was aimed at removing women from the public sphere and reducing their legal rights. Most analyses of Islamization focus on the use of Islam as ideology or Islam as an unvarying, homogeneous cultural system with a particular gender content. In this thesis I seek to redirect attention toward how forms of gendered subjectivity are associated with processes of state formation. I argue that an understanding of Islamization during the 1970s and 80s is nuanced, expanded and historicized through an investigation of an earlier period of Islamization that took place during the social reform movements of the nineteenth century. Parallels between the two periods include the focus on creating a standardized form of Muslim subjectivity and an emphasis on remaking women, both through a denigration of women and a discourse linking women with morality and honour. The first period was associated with a process of liberal state formation and the incorporation of women into society. I discuss this process and how women came to be centrally involved in liberal state formation through their involvement in "the social." I detail aspects of women's involvement in political centralization and nation building during the anti-colonial and nationalist movements of the twentieth century, as well as in post-independence Pakistan prior to 1977. The second period of Islamization was associated with Islamism and neoliberalism, and sought to dismantle state forms with which middle class women were centrally associated, including social government and a national political order. Understanding the fracture in the relationship between women and the state after 1977 requires an understanding of the political project of Zia-ul-Haq and his supporters, and the place of Islamization in it, but also an understanding of the nature of the role played by women in propagating central state authority prior to this project.
\end{abstract}




\section{Acknowledgments}

I would like to convey my respect and gratitude to my thesis advisory committee. Bruce Curtis, my thesis supervisor, propelled me to get this project off the ground and see it through to the end with his combination of open engagement, theoretical insight, high standards, and great expectations. I could not have finished this dissertation without his sustained commitment to me and my work. Sedef Arat-Koç played an invaluable role as a careful and astute reader of my work, and an unfailingly generous and enthusiastic advisor. In his kind, intelligent and supportive way, Behnam Behnia spent many hours over many years listening to me talk about my work and the lengthy illness that interrupted it. I would also like to thank Lorna Weir and Heather Jon Maroney for their assistance at earlier stages of this project, and Pat Armstrong for helping me find my way at a critical point.

The Department of Sociology, Punjab University, hosted me as a research fellow while I gathered primary data in Pakistan. I was welcomed warmly by everyone I met there, especially Dr. Muhammad Anwar and Khursheed Anwar who not so much housed as adopted me. Thanks as well to the organizations that allowed me to use their archives: ASR, Shirkat Gah and Simorgh. I am deeply grateful to the women who agreed to be interviewed for this research; this work is fundamentally informed by their knowledge and accounts, though any flaws in the analysis are mine. It was often the case that those who offered practical advice and assistance during my research in Pakistan also took me into their homes, sustaining me with meals and crucial personal and intellectual support. Therefore I must thank Aitezaz Uddin Ahmad, Dr. Mubarak Ali Khan, and their entire families. It was a particular privilege to enjoy the conversation and company of Dr. Rubina Saigol, an intelligent, grounded, and reflexive activist and scholar.

I simply could not have finished this work without the limitless support of Rosalie Gardezi, my mother. I am equally thankful to my father, Hassan Gardezi, from whom I learned so much. Many others provided support and encouragement along the way including Winston Husbands, Amina Jamal, Erica Lawson, Margaret Phillips, and Jamil Rashid. Thanks especially to Susan Flanagan, my steadfast friend in good times and bad.

The Social Sciences and Humanities Research Council of Canada provided funds for this research, as did the Department of Sociology and Anthropology and the Faculty of Graduate Studies at Carleton University. 


\section{Table of Contents}

Introduction $\quad 1$

Islamization and Social Reform in the Nineteenth Century 4

$\begin{array}{ll}\text { Islamization and Neoliberalism } & 6\end{array}$

Methodological Considerations $\quad 9$

Toward a Genealogy of Islamization $\quad 9$

Sources $\quad 16$

$\begin{array}{ll}\text { Outline of Thesis } & 18\end{array}$

Chapter One: Finding the Woman in the State 21

$\begin{array}{ll}\text { Introduction } & 21\end{array}$

Liberalism and Domesticity $\quad 22$

$\begin{array}{ll}\text { The Social } & 28\end{array}$

The "Woman Question" in the Colonial Context 36

The Contribution of Social Feminism to Nationalism 48

$\begin{array}{ll}\text { Conclusion } & 53\end{array}$

Chapter Two: Social Reform and the Rise of Muslim Nationalism, 1850-1947 55

Introduction $\quad 55$

Religious and Social Reform in Nineteenth Century India 56

Reforming Women $\quad 63$

Educating Women $\quad 65$

$\begin{array}{ll}\text { Purdah } & 70\end{array}$

$\begin{array}{ll}\text { Shariat } & 78\end{array}$

The Moral Woman and Nationalist Politics in Twentieth Century

Colonial India $\quad 82$

Social Feminism $\quad 85$

Piety and Mass Politics $\quad 88$

The Jamaat-i-Islami and the "Islamic State" 92

The Demand for Pakistan $\quad 99$

$\begin{array}{lr}\text { Conclusion } & 102\end{array}$

Chapter Three: Post-Independence Challenges to Muslim Nationalism and Women's Involvement in Nation-Building and State Formation, 1947-1971 104

$\begin{array}{ll}\text { Introduction } & 104\end{array}$

$\begin{array}{ll}\text { Partition } & 105\end{array}$

$\begin{array}{lr}\text { Centralizing State Authority, 1947-58 } & 112\end{array}$ 
Early Challenges $\quad 112$

Continuation of Vice-Regal Rule 118

Islamists and Ulama 120

Women and Nation-Building: Creating "the Social" 124

Geopolitics and State-Building 129

The "Decade of Development," 1958-1969 134

Education and Family Law: The Role of the Housewife
in Modernization

Islam and Government Policy $\quad 140$

Class and Ethnic Inequalities $\quad 142$

Elections and Civil War, 1969-71 144

Conclusion 146

Chapter Four: The "People's Government": Populism and State Feminism, 1971-77

Introduction 148

Emergence of the PPP 149

Economic Policy 153

Liberal Rule and State Feminism $\quad 156$

The Military and Islam 164

Bhutto's Islamization $\quad 164$

Bhutto's Militarism 166

$\begin{array}{ll}\text { Political Opposition } & 170\end{array}$

The Jamaat-i-Islami 170

The Pakistan National Alliance (PNA) 172

Conclusion

Chapter Five: Islamization under Zia-ul-Haq, Part 1: Deconstructing the Nation, 1977-88

Introduction $\quad 178$

Nizam-i-Islam versus Parliamentary Politics 180

Islamic Welfare State 186

Militarization, Islamism and Economic Liberalization 189

Shariat and Military Justice $\quad 191$

"Indigenous" Education 194

Reform of the Individual 196

Prayer 196

Dress 198

Singing and Dancing 199

Sectarianism and Ethnic Violence 201

Jihad 206

Conclusion 210 
Chapter Six: Islamization under Zia-ul-Haq, Part 2: Remaking Women

$\begin{array}{lr}\text { Introduction } & 212\end{array}$

$\begin{array}{ll}\text { Islamizing Women } & 213\end{array}$

The Reorganization of Gendered Space $\quad 213$

$\begin{array}{ll}\text { Islamic Laws } & 221\end{array}$

The Women's Action Forum (WAF) 227

Impact of the Zia-ul-Haq Era 240

$\begin{array}{ll}\text { Depoliticization } & 240\end{array}$

$\begin{array}{ll}\text { Honour and Violence } & 247\end{array}$

$\begin{array}{ll}\text { Conclusion } & 253\end{array}$

$\begin{array}{ll}\text { Conclusion } & 255\end{array}$

$\begin{array}{ll}\text { Glossary } & 265\end{array}$

$\begin{array}{lr}\text { Sources } & 269\end{array}$

$\begin{array}{ll}\text { Appendix A } & 292\end{array}$ 


\section{Introduction}

The observation is commonly made that prior to 1977 there was an accommodation of sorts between women's groups and the various governments, civilian and military, that had ruled Pakistan from its creation in 1947. This accommodation was broken in 1977 with the coup of General Zia-ul-Haq who declared a mission to Islamize Pakistan, which centred largely on regulating women's conduct in myriad ways and which led to a hostile relationship between the government and women's groups. Middle class women in particular felt targeted - the group of women most closely allied with previous governments, but also with centralized political authority or "the state" in general as a guarantor of "women's rights." I present this falling out between women's groups and the government as the nub of a much larger story, and an organizing point around which this thesis unfolds. My aim in this thesis is to offer an understanding of this conjuncture that differs from those offered to date in two interconnected ways. Firstly, I propose a genealogical approach to understanding Islamization - one that examines its articulation in another historical context that also involved intense focus on the conduct of women, and that locates it as a moral project linked to state formation rather than simply as an offshoot of a proclaimed mission to establish Islamic rule. Secondly, I argue that the gender content of Islamization should be contextualized in relation to a link between state formation and gender formation and the historical role of middle class women in liberal state formation.

The program of Islamization pursued by Zia-ul-Haq involved a number or measures, including the development of new Islamic taxes, changes in school textbooks and course curricula to make them more Islamic, reforms to the judiciary permitting more 
involvement of Islamic clergy and giving more importance to shariat, and the legislation of new Islamic criminal laws and punishments, most notably in the area of sexual morality. Many legal changes, government directives and government-sponsored media campaigns focused on women. For example, they attempted to enforce the wearing of head coverings in schools and government workplaces, and to remove all representations of women in the media except as housewives and mothers. In general, women's bodies and their appearance outside the home were labeled and portrayed as obscene, the domestication and seclusion of women were promoted as ideals, and working women in particular were accused of immoral behaviour and blamed for all societal problems (Said Khan, 1988). New laws passed at this time reduced the value of women's testimony in court compared to that of men, and created a situation in which large numbers of women, including women who were raped, were charged with adultery.

Analyses of Muslim politics typically privilege understandings of Islam as a presumably self-contained cultural system or Islam as ideology (Hasan, 2000:4). These explanations are similarly evident in analysis of the period of Islamization in Pakistan from 1977 to 1988 . The predominant explanation offered for the government's Islamization platform is the attempt to seek popular legitimacy for, or deflect protest against, the 1977 overthrow of the government of Zulfiqar Ali Bhutto by the Chief of Army Staff, General Mohammad Zia-ul-Haq, and the subsequent eleven year period of military rule (Alavi, 1986; Jalal, 1990; Malik, 1996; Mehdi, 1994). Some also have suggested that pursuing Islamization by targeting the behaviour of women was easier and less threatening to financial interests than restructuring economic relations according to Islamic tenets and, furthermore, was less likely to offend "the sensibilities of Pakistan's 
male dominated society" (Jalal, 1990:323). Other accounts emphasize the mutually beneficial convergence of the military and Islamists in Pakistan in the regime of General Zia-ul-Haq (Mumtaz and Shaheed, 1987), and the personal religiosity of Zia-ul-Haq (Richter, 1979).

Accounts focusing on the use of Islam to suppress dissent neglect what Islamization may have been about creating or producing. As well, approaches that focus on the strategic/ideological deployment of Islam or the rise to power of Islamic actors leave the impression that the gender content of Islamization derives in some self-evident manner from Islam itself. Attempts to deduce practices associated with Islamization from "Islam" itself only further the objectification of Islam that is characteristic both of various forms of Islamist practice and discourse (Eickelman and Piscatori, 1996:37-45) and of culturalist perspectives predominant in western discourse on Islam (Roy, 2004:9). In this sense, it is helpful to understand what Islamization is at a more fundamental level, over and above the particular political program of Zia-ul-Haq's regime.

I understand Islamization as a moral project, a project that reforms individual behaviour in order to create a universal Muslim subjectivity; or, as Faisal Devji has suggested, posits an abstract form of Muslim individuality in the process of building a Muslim polity (2008:386). ${ }^{1}$ More than simply a strategic use of Islam to achieve political ends, Islamization is a project of making standardized Muslims; in other words it is a project of cultural formation, and I suggest in this thesis that it is a project of cultural formation that proceeds alongside state formation. I borrow here from Philip Corrigan and Derek Sayer (1985) who describe English state formation as "cultural revolution."

\footnotetext{
${ }^{1}$ Previously published in South Asia, 14 (1), 1991, and in Zoya Hasan (2004).
} 
The ethical Muslim self was linked to political projects and modes of rule that relied on the notion of a moral collective. Seen in this light, Islamization is a process that has been evident since the social and religious reform movements of the nineteenth century.

\section{Islamization and Social Reform in the Nineteenth Century}

During the latter half of the nineteenth century, movements of "socio-religious reform" (Jones, 1989) were underway involving all of India's religious traditions, including Islam: movements that sought to reform individual conduct more generally, emphasizing new personal habits and traits such as industriousness, frugality; new forms of domestic practice; and standardized, rationalized, textually-derived, "correct" religious practice. Though the period of social reform usually is not linked to Islamization, it did entail a process of reforming individual conduct and promoting an ethical Muslim subjectivity. These movements were also centrally concerned with the conduct of women, and produced voluminous quantities of literature including guidebooks, novels, and women's journals prescribing correct conduct for women. Attempts to increase women's awareness of religious scripture, took place in conjunction with attempts to reform family and home and to promote the new practice, or rather "science," of homemaking. Reformers were centrally concerned with making women Muslim (Devji, 2008), with creating a pious and scripturally-aware subjectivity for women, and with incorporating women into emerging understandings of Muslim collectivity.

The period of social reform also contained a strong denigration of women. If women were claimed to be the root of all immorality during the Zia-ul-Haq period, they were denigrated as doing everything wrong by the reformers of the late nineteenth century. But in both cases this denigration existed alongside claims that the honour and 
virtue of the community reside in women. I argue that rather than a reassertion of patriarchy, or a simple expression of misogyny, the critique of women was aimed at remaking women - at changing the culture of women, particularly middle class women. In the case of nineteenth century social and religious reform in India from roughly 1860 until the 1890s, processes of making women moral and of incorporating women into society, were connected to what Devji (2008) refers to as "polity-building." I agree, although Devji is somewhat vague on the nature of this polity. This new polity is based on asserting the moral authority of the middle class, but also extending and diffusing morality through techniques that incorporate all into a social whole. I discuss the Islamization of women, a process of moral reform that involved the emergence of the modern subject positions of housewife and mother, as connected to what Corrigan and Sayer (1985) refer to as the twin processes of individualizing and totalizing in conjunction with liberal state formation.

I argue further that what begins with an incorporation of middle class women into society through education, reform of the family and making women moral, continues with middle class women's vital involvement in centralizing state authority and extending government through "the social." Middle class women's movements support the nation state through philanthropy and social work, by advocating that the family be governed by juridical norms, by furthering notions of citizenship, and by promoting ideas of individual moral responsibility in service to "the nation." This is done through modern techniques of governing populations, including health, hygiene, medicine, family planning, philanthropy, schooling, and literacy and vocational training, among other means. 


\section{Islamization and Neoliberalism}

As I will discuss in this thesis, Zia-ul-Haq argued against the concept of society, suggested that any and all issues or problems facing the country were problems of individual conduct, and sought to undermine institutions and practices that represent, create or regulate the nation state. I will argue that the efforts of the Zia-ul-Haq government to portray women engaged in employment, activism, or social work, as immoral were related to attempts to denationalize government. Though this is not a thesis that directly explores the complex configurations of globalization, the beginnings of several features that are linked to processes of globalization and the rise of a neoliberal rationality are evident during Zia-ul-Haq's rule. These include the destabilization of the nation state and national sovereignty, heightened responsibilization of the individual, the discrediting of the social and the political (Dean, 2003:117; 2007), forms of "theological statism" (Brown, 2006a); and what Sassen (2003:2) describes as the dual appearance of political forms and practices that link either to global processes and institutions or to deeply localized politics that orient not to the nation, but to other localized points transnationally.

If a nation is an imaged community that is limited and sovereign (Anderson, 1991), Islamism - a type of Islamic revivalist movement that emerged in the twentieth century promoting the concept and creation of an "Islamic state" - does not envision a moral community that is bounded by the nation, or locate sovereignty in the secular concept of the nation. In the case of colonial India, the Muslim nationalist movement that led to the creation of Pakistan was opposed by Islamists and most other Islamic revivalist parties. Yet, in Pakistan and elsewhere, Islamists do operate in a context shaped by nation 
states and often borrow the language of "the nation" in the attempt to capture state power (Asad, 2003). As Moaddel writes, Islamism is shaped "in a dialogic manner" by liberal nationalist discourse (2005:198-99), but Islamist and nationalist concepts of space, time, and history are substantially different (Asad, 2003).

According to Ismail (2003), Islamist politics make available a position of resistance to the state. Certainly in Pakistan, local political actors have at times declared their localities to be under "shariat law" as a means to deny the authority of the central state. Though Islamist parties regularly become involved in electoral politics where they are able to do so, Islamism also relies on techniques for establishing local authority and challenging nation-state authority. Violence is one such technique, but Islamist organizations also operate their own schools, charities, and health clinics. Operating out of mosques and through local religious leadership, they often establish mechanisms for arbitrating disputes in neighbourhoods and rely on "volunteers" to conduct policing and surveillance, including monitoring the religious observance and gender interaction of local residents. As opposed to the national subject - the citizen - an Islamist polity is based on a type of activist Muslim self (Hirschkind, 2001:11) concerned with cultivating "right" and suppressing "wrong" conduct in oneself and others. In the case of Egypt, Ismail (2006) argues that such movements grew during the 1970s associated with economic liberalization and the growth of urban "spheres of dissidence": sections of the urban middle class that rely on the informal economy, guild-type jobs, or irregular employment, and live in areas of cities that are marginally integrated into government infrastructure and services. The burgeoning growth of international migrant labour at this 
time created another section of the middle class that exists outside national citizenship and citizenship rights.

Islamization in Pakistan during the 1980s did reflect the emergence to power of Islamist parties through a military takeover, a military in which Islamists had been a growing constituency for a number of years, but their support also had been growing among sections of the urban middle class during the 1970s. Although Islamism is opposed to liberalism in the sense of freedom of individual conduct regardless of the dictates of religion, it is not opposed to the economic rationality of liberalism, and Islamization associated with Islamist government during the 1980s entailed processes of depoliticization and of individualization observed by some to be hallmarks of the political rationality of neoliberalism. ${ }^{2}$ According to Wendy Brown, "Depoliticization involves construing inequality, subordination, marginalization, and social conflict, all of which require political analysis and political solutions, as personal and individual on the one hand, or as natural, religious, or cultural on the other" (2006b:15). In fact, women activists I interviewed used the term "depoliticization" to describe the process they experienced during the 1980s in Pakistan, as I discuss in Chapter Six. I argue that the attempt to re-Islamize women in the 1980 s relates to an attempt to reform women's subjectivity away from the middle class, rights-claiming, social work-oriented woman who is identified with a national political order. In a preceding liberal politics, middle class women were strongly linked to the nation, in fact they were "mothers of the nation." Women were not only symbolic of the nation, but through their organizing, social work

${ }^{2}$ And also of classical liberalism (Brown, 2006b:17). 
and activism, they helped to create, perform and perpetuate it. This form of womanhood comes to be portrayed as immoral in a neoliberal politics against social government.

\section{Methodological Considerations}

\section{Toward a Genealogy of Islamization}

The methodological approach I take here to studying Islamization can be characterized as genealogical. Seeing Islamization from the perspective of a moral project to assert an abstract form of Muslim subjectivity situates it as a process that is pursued or implemented not only by Islamists - those that have claimed an explicit agenda to bring about an Islamic state or polity - but in other contexts as well, and serving different sets of interests, including those of liberal reformers. While much has been written about Islamization in Pakistan during the regime of Zia-ul-Haq, less attention is given to how and why a proclaimed mission to implement an Islamic system manifests as the reform of the individual, of gendered space, or of domestic practices. In investigating an earlier period of similar intensive reforms, my intention is not to claim that the two historical periods bear similar overarching traits, or that one period inevitably led to the other, but rather, to show that practices of making standardized Muslims have historically been situated within a range of projects: liberal, nationalist, secular, Islamist. I suggest that what this approach makes visible is the connection between Islamization and state formation, as well as state formation and gender formation.

The approach I take is aligned with a Foucauldian approach that locates the focus of historical inquiry in practices of government and "regimes of practices," and that examines how such practices are connected with complex historical processes (Foucault, 1991:75). Rather than arguing evolution, linearity or continuity, a genealogical approach 
engages in detailed documentation of accidents, contingencies, and "passing events in their proper dispersion" (Foucault, 1984:81). In this thesis I attend to historical complexity, contingency and the way that projects to elaborate a Muslim subjectivity linked with practices that were similar in some respects despite radically different dimensions to their political imaginaries. My approach is to conduct a detailed study of Islamization, state formation and gender formation, covering the period from nineteenth century social reform among Muslims in colonial India to the beginnings of a neoliberal order in Pakistan during the 1970s and 80s. Throughout, I make use of a language of "projects," "regimes" and formation to suggest the temporal and conjunctural nature of the processes I describe. Here I also borrow from R.W. Connell's (1990) use of the terms "gender regimes" and "gender order/political order" to suggest historically constituted sets of relations, cross-cut by multiple dimensions, modalities or arrangements of power in place of unitary and transhistorical models such as "the state" or "patriarchy."

This approach historicizes Islam, as well as concepts such as liberalism and modernity and, in so doing, somewhat unsettles them. The suggestion that Islamization is linked to liberal state formation, and the claim I make here that nineteenth century north Indian women were incorporated into liberal projects through processes of being made Muslim (and also made Hindu or Sikh), go against ubiquitous and politically powerful assumptions locating Islam and liberalism in divergent "civilizations,"3 timelines of modernity, or modes of government or political culture. I do not intend to detail and critique these approaches here, but by way of clearing space for the work that I do undertake, I would like to make a few comments at the outset regarding two widely held

\footnotetext{
${ }^{3}$ As in the "clash of civilizations" thesis advanced by Bernard Lewis (1990) and Samuel Huntington (1996).
} 
assumptions: that Islam is not modern, and that Pakistan's history lies outside the history of liberalism rather than being situated within and shaped by it.

It is often assumed that Islam is not modern, but reflects a traditional culture or mode of life, or that Islam is anti-modern. Over the past two centuries, Islam has been imbricated with modern practices and understandings of state, law, religion and morality. While some writers suggest that Islam inherently makes no distinction between religion and politics, and attempt to locate the politics of contemporary Islamist movements in essential features of Islam itself (Esposito, 1998; Voll, 1994), others suggest that movements demanding Islamization of state and society cannot be understood apart from the power of modern state forms whose legal and administrative structures shape and regulate so much of life (Hirschkind, 1997:13). Certainly the political demand for an "Islamic state," which began to be articulated by Islamist groups in the twentieth century, is shaped by modern notions of state and law, and particularly by a reformed concept of shariat as "Islamic law." Several writers have discussed the transformation of the discourse of shariat - the craft and the practice, the institutions, the modes of derivation and transmission - into fixed legal codes under the influence of colonial projects in Muslim lands in the eighteenth and nineteenth centuries (Brown, 1997; Messick, 1993; Mitchell, 1991: 82-85, 101). During the twentieth century, this transformed shariat came to mean different things to different political groups. For liberal nationalists, it meant family law - a means for the nation-state to shape and administer the modern family based on monogamy and companionate marriage (Asad, 2003:229-230). For Islamists who sought to create an "Islamic state," shariat meant a code of conduct and practices that focus on individual conduct, particularly prayer and Islamic penal laws (Nasr, 
2001:141). While Islamists and nationalists both employ understandings of shariat as codified law (though with very different emphases and interpretations), the ulama, (formally-trained scholars and interpreters of Islamic texts and traditions) adhere to historical schools of interpretation, for which they are often labeled "Islamic traditionalists." Yet, during the nineteenth century, the ulama refashioned themselves from their traditional role as advisors to rulers into a new role as guides to individual Muslims on all aspects of life (Metcalf, 1982:46-52). In some contexts, including Pakistan, groups of ulama have advocated a separation of religion from the state to maintain a sphere of autonomy and to constitute themselves as experts in the specialized field of "religion" (Zaman, 2002:98-99). Such an understanding of Islam as "religion" with an autonomous essence separable from politics is rooted in the modern concept of religion accompanying post-Enlightenment politics of secularism and nationalism (Asad, $1993: 28 ; 2003: 181-201)$.

The notion that Islam exists in tension with modernity also is problematized by the multiple points of overlap between Islamist and liberal secularist politics (AbuLughod, 1998b; Hatem, 1994; Rouse, 1992). I discuss this further in the body of this thesis, however, at the outset, it is important to point out that Islamist politics arose from an urban educated middle class base, one that accepted capitalism and private property; valued scientific and technological knowledge, even if suffusing such knowledge with religious idioms; and promoted the notion of the rational, responsible individual, though with stronger resort to techniques of pious self-formation. Islamist and secularist perspectives on modern domesticity are substantially similar, emphasizing companionate marriage, women's central role as mothers and housewives (i.e., specialists in child 
rearing and domestic science), and the need for education for both women and men. Both Islamism and liberal secularism, to the extent that they seek to shape the conduct of women, are less interested in the conduct of poor women compared to middle class women. ${ }^{4}$

This thesis also draws attention to the crucial role of liberal practices in the history of Pakistan. The period of social reform among Muslims during the latter half of the nineteenth century was associated with the rise of middle class movements that established schools, voluntary associations and philanthropic trusts; advocated reform of the family; articulated theories of individual responsibility; and formulated new understandings of Islam that focused on the rational, individualized subject whose morality was asserted through racialized discourses of respectability that simultaneously critiqued the wastefulness of various wealthy and powerful classes. This is a process I link to cultural components of liberal state formation, though, as Mushirul Hasan points out, the liberal content of nineteenth century Muslim reform in India is often ignored in favour of characterizations of Muslim reform as "communal" or "separatist" (1998:1078).

\footnotetext{
${ }^{4}$ Beginning in the $1980 \mathrm{~s}$, a form of Islamic activism began to emerge that has been called "jihadism" (Devji, 2005) or "neo-fundamentalism" (Roy, 2004), which is organizationally more diffuse, and less ideologically or doctrinally coherent, than Islamism. Ismail (2006) uses the term "conservative Islamism" to distinguish groups such as the Jamaat-i-Islami in Pakistan and the Muslim Brotherhood in Egypt from this new variant of "jihadist Islamism." A well known example of the latter is the Taliban, which was famous for enacting one of the strictest codes of conduct for women during its 1996 to 2001rule in Afghanistan, including banning education for girls. However, even with regard to the Taliban, edicts prohibiting women from working and mandating the wearing of the burqa appeared to go unheeded by poor women working in fields (Hirschkind and Mahmood, 2002:346).
} 
There is a tendency to view liberalism and nationalism in colonized countries as western imports. However, Stoler and Cooper argue that both colony and metropole be brought "within the same analytic field" rather than viewing European empires as "selfcontained entities that at one point projected themselves overseas" $(1997: 1,16)$. In fact, European colonies served as the location for the emergence of many of the categories by which imperial powers came to understand themselves and their "western" history, including: "liberalism, nationalism, state welfare, citizenship, culture and 'Europeanness' itself" (Stoler, 1995:16). British colonial rule in India became a laboratory for experimenting with and exporting liberal forms of administration including schools, courts and a competitive civil service (Metcalf, 1995:29). This is not to say that the British Raj straightforwardly propagated liberal rule in India itself. Cohn (1983) describes the dilemma the British faced over whether to rely on "feudal" or "representational" modes of government, opting largely for the former. In Chapter Three I discuss how, in the regions of India that eventually became Pakistan, British administration relied on two decidedly nonrepresentational forms of administration: the creation of a feudalistic landowning class in agricultural areas, and the delegation of sweeping military and police powers to tribes or local kinship groupings in the frontier areas of the empire not under direct British administration.

With regard to women's rights, while colonial authorities enacted legislation to prohibit practices they found egregious, these measures often had the opposite effect. ${ }^{5}$

\footnotetext{
${ }^{5}$ For example, the Hindu Widows' Remarriage Act of 1856 sought to counteract scriptural prohibitions against widow remarriage by removing widows' entitlement to property and inheritance from their deceased husbands if they remarried. In fact, the majority of Hindus did not observe prohibition of widow remarriage, and by impoverishing widows if they remarried, the law became a deterrent to remarriage
} 
Though legitimizing discourses of empire persistently claimed to be saving Indian women from Indian men, it was the indigenous urban middle class that sought social reforms including "women's rights" as part of liberal and nationalist projects. Rather than supporting these groups that would supplant their rule, colonial officials promoted and supported groups such as landowners who were largely opposed to women's rights agendas. Furthermore, although British authorities instituted a court system in which the concept and practice of individual rights could be pursued and propagated, they simultaneously undermined this system through the above mentioned forms of administration in which courts had little relevance.

While present day Pakistan is often associated with "extremism" and military rule $^{6}$ rather than liberalism, a classification of Pakistan as non-liberal is complicated by factors such as the presence of a judiciary in Pakistan that has frequently (though not consistently) overturned decisions of military rulers or other state executives that impinged on the legal or constitutional rights of political actors (Nasr, 1997:138-141; Newberg, 1995). ${ }^{7}$ Other complicating factors include parliaments in which secular and

(Carroll, 2008). With regard to sati (widow immolation), colonial regulations in Bengal in 1812 attempting to distinguish "voluntary" from "coerced" sati created the impression of official sanction for sati and were related to an increase in its incidence (Datta,1988; Sangari and Vaid, 1989:15).

${ }^{6}$ Since its creation in 1947, Pakistan has been under military rule from 1958 to 1970 , 1977 to 1988 and 1999 to 2008 .

${ }^{7}$ One of the clearest examples of conflict between the judiciary and state executives took place in 2007 when the Chief Justice of the Supreme Court was dismissed by the country's military ruler, General Pervez Musharraf. This was in part because of judicial questioning of the constitutionality of Musharraf's ambitions to become President after parliamentary elections in 2008, as well as the Chief Justice's announced intention to question military intelligence officers over the "disappearances" of thousands, of Pakistanis since the beginning of the country's involvement with the American "war on terror" (Harrison, 2009). A subsequent two-year protest movement by the country's 
religious politicians are compelled to talk to each other, the absence of large-scale state suppression of Islamist groups despite their fundamental antagonism to the state, and Islamists' history of adopting techniques of representative government such as contesting elections and populist politics. I make these points to indicate that liberal state forms are operative in Pakistan's politics, not to minimize the frequently authoritarian nature of political rule in Pakistan, or the militarization that has occurred in the country over time and at a particularly staggering rate since the 1980 s. Attention to the history of the military is unavoidable in any account of state-building in Pakistan. I give it attention also, alongside a history of dimensions of liberal government, so that militarization is seen in its historical context rather than assumed to be merely another indicator of Pakistan's failed modernity.

\section{Sources}

I rely primarily on secondary sources for investigating the period of social and religious reform in nineteenth century colonial India, the period of anti-colonialism and nationalism during the first half of the twentieth century leading to the partition of India and creation of Pakistan, and the period of state building in independent Pakistan from 1947 to 1977 . In addition to consulting secondary sources, I gathered primary data related to the period of Islamization under Zia-ul-Haq from 1977 to 1988 , focusing specifically on the government's stated intentions and descriptions of its policy of Islamization, debates among politicians over Islamization, and responses of women's groups to Islamization. For the first two issues, I rely particularly on the political speeches of Zia-

lawyers eventually contributed to the downfall of Musharraf and the reinstatement of the Chief Justice. 
ul-Haq and records of debates in the National Assembly and Senate of Pakistan for the period of 1985-1988. I also consulted records of debates in the consultative body created by Zia-ul-Haq, the Majlis-e-Shoora, which sat from 1983 to 1985 . Both speeches and records of debates were obtained from the National Assembly Library in Islamabad. Islamization also proceeded through proposals, reports, proclamations, public statements, campaigns, laws and government directives. Information on these varied aspects of government discourse and policy was obtained through newspaper archives, copies of government reports, secondary sources, and archival records of nongovernmental organizations, including several women's organizations (ASR, Shirkat Gah, and Simorgh) and the Human Rights Commission of Pakistan. These organizational archives also contained declarations, position papers, newsletters, and press releases of human rights and women's groups during the Zia-ul-Haq period, and unpublished reports and research on the effects of Islamization.

Though I was not able to obtain any interviews with those associated with the government of Zia-ul-Haq, I conducted twenty unstructured interviews with women activists, touching on the policies of the government, the responses of women's groups, and the social effects of Islamization. The women belonged to a number of different organizations, described in Appendix A, including political parties, trade unions and women's organizations in Lahore, Islamabad and Karachi. All were active in the Women's Action Forum, an umbrella organization that was formed in 1981 to respond to the government's policies. I identified women to interview by talking to women's organizations and identifying women who were well-known activists, as well as women who represented different opinions within WAF. In one case an interpreter was used, 
while in other cases the interviews were conducted in English or a mixture of English and Urdu. Interviews were conducted in 1995 and 1996, approximately seven years after the end of the Zia-ul-Haq period.

\section{Outline of the Thesis}

In Chapter One I discuss theories of gender and liberal modalities of power. I suggest that these approaches do not pay sufficient attention to changes in the gender order accompanying the emergence of liberalism, including the extent to which women were assigned a moral status on par with men, and the interdependence of public and private in emerging practices of domesticity. I suggest that to understand how middle class women play a constitutive role in liberal state formation, it is important to consider their role in "the social." I also review literature on debates about the family and domesticity in nineteenth century colonial India, and I provide an example of how the focus of women's groups on social reform supported nationalist movements in twentieth century colonial India.

In the first part of Chapter Two, I discuss social and religious reform among Muslims in India during the latter half of the nineteenth century. I describe efforts to "Islamize" women and reform the family through education and reform of the system of purdah (women's seclusion). I also discuss attempts to support modern domesticity through "shariat law." The second half of the chapter deals with women's involvement in the politics of nationalism and anti-colonialism during the first half of the twentieth century, until independence from colonial rule in 1947. I also discuss the formation of an Islamist movement during the 1930s that opposed both nationalism and the growing activism of middle class women, and I discuss the rise of the demand for Pakistan. 
I begin Chapter Three with a discussion of the partition of India and Pakistan, and proceed to discuss the challenges of state-building in Pakistan from the creation of the country in 1947 until the civil war of 1971 and secession of East Pakistan (Bangladesh). From the outset, central state authority in Pakistan was on a tenuous footing for multiple reasons that I outline in this chapter. I also discuss how women's organizations carrying out social work and promoting state regulation of the family were key proponents of political centralization and nation-building. I describe how other techniques of state building emphasizing modernization theory, bureaucratic oversight and economic development theory contributed to popular crises and protests movements advocating greater regional autonomy or socialism. The formation of a military to serve Cold War interests, and which furthered the prospects of Islamism in Pakistan in subsequent decades, is also discussed in this chapter.

Chapter Four discusses the brief era of socialism in Pakistan from 1971 to 1977. This period was associated with an increased feminization of the state through expanded public sector employment of women and policies that facilitated women's employment, such as maternity leave. Nationalizations, land reforms, and labour policies also created a large public sector and extended workers' and peasants' rights. Opposition to the PPP government from business and industry and sections of the urban middle class crystallized around the discourse of Islamism and demands to return women to the home.

Chapters Five and Six focus on the period from Zia-ul-Haq's military coup in 1977 until his death in 1988. In Chapter Five I describe the policy of Islamization pursued at this time as one of undermining institutions, practices and cultural forms that 
create the nation and national identifications. In Chapter Six, I describe the process of attempting to dismantle social government through a process of re-Islamizing women. In the concluding chapter, I briefly summarize the arguments made here and the contributions of this thesis to existing research, and I provide a brief discussion of how processes studied here continue to impact on the present.

Transliteration: I have followed conventions within English-language writing by Pakistani authors for English transliterations of Urdu words. For Urdu words that derive from Arabic, I have used the Urdu spellings. Urdu words are presented in italics the first time they are used in the text, and thereafter are not italicized. 


\section{Chapter One \\ Finding the Woman in the State}

\section{Introduction}

The title of this chapter is borrowed from Wendy Brown's 1992 article entitled "Finding the Man in the State," in which she sought to trace the workings and expressions of masculinist state power. In this chapter I conduct a similar exercise by tracing the lines of feminine power within modern state forms but through a modality of power that is not usually included in discussions of state power - the social. The idea of "finding the woman in the state" may appear to be counterintuitive as there is a longstanding tendency either to ignore women in theorizing state power, or to emphasize how women are pervasively excluded from structures of power, or marginalized as political subjects. When women are aligned with political regimes, including undemocratic or authoritarian ones, such alignment is often seen as resulting from political expedience or co-optation. I suggest that there is something more fundamental and constitutive to the relationship.

I begin this chapter by discussing theoretical perspectives on gender and the state in liberal political formations. Research on gender and liberal government typically has emphasized women's exclusion from full citizenship and their relegation to an extra-legal private domain, suggesting that public rights are often in tension with private patriarchy. I suggest that women in fact play a central role in liberal modalities of power through "the social." In this chapter I discuss what is meant by the social and I provide an example of how women's involvement in social reform helped to further liberal state formation, including notions of citizenship and nation in India. Before women came to play this role in the social, there was a period of constituting women as ethical subjects. I review 
theories of the nineteenth century "woman question" and I argue that this period be seen as one of cultural revolution accompanying state formation.

\section{Liberalism and Domesticity}

Feminist theorists exploring the gendered workings of liberal modalities of power, have highlighted the extent to which liberal political theory has regarded categories such as the family, motherhood, and gendered subject positions, such as the male breadwinner and the housewife, as part of a private realm, separate from the political realm of the public or "civil society." However, those attempting to redress this absence of attention to the family in state theory have tended to see these normalized categories primarily as bases of exclusion of women rather than means and devices through which liberalism is constituted and women are included in liberal rule. For Carole Pateman (1988), the social contract establishing legal equality is also a sexual contract that establishes men's political right over women and sexual access to women's bodies in a private sphere that is not permeated by liberal rights. According to Catherine MacKinnon (1989), constitutional liberalism protects citizens against violation of their rights by government, but not by other citizens. Women are denied the status of citizens because the law does not guarantee equality, liberty, or privacy within the extra-legal domain of the family.

It is not clear, however, why the private is a sphere of unfettered male dominance as it is for MacKinnon who suggests the ahistorical workings of "family and kinship rules and sexual mores" as a basis for women's subordination (1989:237). Pateman employs the similarly ahistorical concept of patriarchy, ${ }^{1}$ although she qualifies it as a "fraternal

${ }^{1}$ Though some have attempted to historicize the concept of patriarchy, such as Kandiyoti (1988) and Miller (1998). 
patriarchy" because of the equality of men under civil government. Also unclear is how "family law" (which men's rights movements at times have claimed privileges the female subject) fits into the notion of the family as an extra-legal category. In the case of colonial India, as I discuss in the next chapter, the promotion of some legal rights for women within the family, including property rights, was a major political objective of liberal Muslim nationalists in the twentieth century. The family is also taken as given despite the considerable debate about the family and domesticity, and the proper role and conduct of women, which took place during the nineteenth century concurrent with the extension of liberal political and economic arrangements. For Susan Okin, the "domesticated, sentimental family" is an ideology that came to the rescue of patriarchy, under threat from newly emerging ideas of individualism in the seventeenth and eighteenth centuries, by divesting women of the rationality necessary for citizenship (1982:74). This does not acknowledge, however, that men were part of this emerging domesticated, sentimental family; notions of masculine honour came to be vested in the role of the domesticated "family man," though not without prior and continuing contestation over appropriate forms of respectable masculinity (Davidoff and Hall, 1987:108-113). If domesticity as an emerging cultural form confers dishonour and diminished status on women, how does it simultaneously confer honour and esteem on men?

Others have proposed that there is a more historically contingent and concurrently arising relationship between the formation of gendered subjectivities and the rise of liberal political arrangements that are better described as "masculinist" (Brown, 1992) or "historically patriarchal" (Connell, 1990:535). For example, Wendy Brown (1992) 
suggests an "interconstructive" relationship between liberalism as a structure and discourse that is individualistic, as opposed to relational, and bourgeois masculinity (1992:20). Similarly, with regard to the nineteenth century emergence of a hegemonic masculinity emphasizing "rationality, calculation, and orderliness" concurrent with the emergence of liberal constitutional political authority, Connell writes: "This change in gender was not a consequence of the bourgeois revolution, it was a central part of it, part of the dynamic that created modern industrial capitalism as an already-gendered social order" (emphasis original) (1990: 521-22). I agree with the suggestion that gendered subjectivities are formed in the process of liberal state formation and the argument I make is fully consistent with Connell's point that "we need to appraise the state from the start as having a specific location within gender relations, and as having a history shaped by a gender dynamic" (1990:519-520). However, the focus remains on masculinist power. Similarly, I situate this thesis within Corrigan and Sayer's point that the separation of public and private is about state formation as cultural revolution, and that masculine and feminine subjects are created in and through processes of state formation. However, again the focus is on the state as a male institution, the workings of which leave women denied rights in the private sphere, and excluded from public existence until the second or third decade of the twentieth century (Corrigan and Sayer, 1985: 12, 36-37, 132-33, 141-43). Again, one is not sure how nineteenth century debates on domesticity, a revolutionary project of remaking home, family and gendered subjectivity, fit into this theorizing of liberal state formation.

The separation of public and private taking place over the decades of the late eighteenth and early nineteenth centuries in conjunction with bourgeois capitalist and 
liberal state formation did involve a distinction between masculine and feminine and a the creation of a spatial division that came to exercise force over people's lives. The domestic husband/father was construed as "head" of the household; what women did in the home was not acknowledged as "work" or "production"; and these changes were reflected in law and official practice. The difficulty, I suggest, lies in leaving the private, home and family outside the analysis of power - in not seeing them as sites from which power is exercised - and in discounting the simultaneous assignment of moral equivalence to women and men that accompanied the distinction of masculine and feminine realms. Brown emphasizes that when women enter the public or civil realm, they are required to "repudiate or transcend" those female values of caretaking that are the currency of their daily lives in the private sphere as "the liberal state appears to be socially masculine: its discursive currencies are rights rather than needs, individuals rather than relations, autogenesis rather than interdependence, interests rather than shared circumstances" (Brown, 1992:20). But what of the processes that resulted in the equation of women with needs, relations, interdependence and shared circumstances? Are these not the terms upon which middle class women have been included in, rather than excluded from, liberal modalities of power? And is a politics based on the assertion of these "feminine" qualities and practices, which middle class women have deployed, assumed to be marginal to dynamics of power in liberal states and unconnected to processes of normative correction, surveillance, support for imperial projects, or, at times, even outright coercion?

I present two alternative perspectives that read the gendered division of space into public and private as an axis of inclusion in, rather than exclusion from, liberal rule: one 
that emphasizes the professionalization of women's domestic work, and another that emphasizes how women are uniquely tied to the emerging concept of population. In the first case, Judith Newton draws on the work of Corrigan and Sayer (1985) in suggesting that the separation of domestic and public was part of a cultural or moral revolution that involved both a heightened gender division, but also "complex negotiations in regard to gender sameness and difference" (1994:126). While domestic and public spheres were distinguished, the domestic was also a continuation of the public. In fact, the domestic or private is described as a miniature version of the public political world. Hence the description of women as "ministers of the interior," taken from an 1833 Edinburgh newspaper article, which Newton contends signifies "as many parallels between women and men, domestic and public, as it does differences, and as part of an argument for excluding women from formal political power, it also politicizes the domestic sphere" (1994:126). Women's domestic labour is "professionalized," a basis for their service to new political forms of public, nation, and race. This emerging politicization of women is evident in nineteenth century debates about the place of women in the emerging social order commonly referred to as "the woman question." In these debates women are made moral, both through their incorporation into the discourse and practice of evangelical Christianity, and through an understanding that women represent a moral ethos that is cooperative, familial, and geared to the collective interest rather than self-interest. This new moral woman plays a fundamental role in middle class claims to cultural and political authority, including claims to racial or national superiority.

The importance of the private and women's new domestic roles in liberal government is also suggested in theories of biopolitics. According to Ruth Miller, 
gendered citizenship is created not through an exclusion of women but through a mechanism of biopolitics that is "relentlessly inclusive" (2007:353). Drawing on the work of Michel Foucault and Giorgio Agamben, Miller argues that modern political sovereignty is not only juridical, but also biopolitical; resting not only on the rights of the individual, but also on the health of the population. While Newton highlights the professionalization of women's domestic role and the continuation of private and public, Miller notes how health, hygiene, medicine, reproduction, nation and race, are extended not only into the home, but into the womb. By examining Ottoman and subsequent Turkish, as well as French and Italian, legal codes governing abortion and adultery, Miller argues women's sexuality becomes public, "with every private aspect of their lives displayed and regulated for the sake of the common good" (Ibid:367). Biopolitics is also premised on the moral equivalence of women and men. Miller's research suggests that the equality of men and women - their union in the same moral space - is at the heart of why women come to signify honour, race, and collective, and results in their sexualized citizenship: "It is precisely when women are made equal to the male norm...that the womb becomes an inviolate place possessed not by an individual woman but by each and every citizen in the modern nation-state" (Ibid:361).

My analysis draws on the perspectives offered by both Newton and Miller, including their portrayal of the interrelation between public and private, the moral equivalence of women and men and the concept of population. These are all components of the social. Below I suggest that women are uniquely identified with the social, and that middle class women have played a fundamental role in liberal state formation through the social. 


\section{The Social}

Numerous writers have identified a sphere of intervention, regulation, discipline, surveillance, administration or control associated with liberal governance and designated as "the social" (Dean, 1991, 1999; Donzelot, 1979, 1988; Mitchell, 1991:100-127;

Poovey, 1995; Procacci, 1991; Steinmetz, 1993; Valverde, 1991). There is variation in how the social is conceived as an abstraction. Steinmetz refers to the social as "a space between the economy and the state" (1993:2). Valverde suggests that it "is not so much a separate sphere but a new way of conceptualizing any and all problems of the collectivity" (1991:20). For Dean, the social is expressed in a range of questions, practices, institutions, and personnel "that maintain and interconnect formally constituted 'private' and 'public' divisions (between business and the state, between the family and the state)" (1999: 53). Generally, the abstraction referred to as the social is conceived as something other than, a space additional to, or a rationality that inhabits the interstices of, the individual, the economy and the state (themselves abstractions). Its beginnings are located in attempts to diffuse the potential for disorder and conflict, or the threat of chaos, created as capitalism developed, attempts that focus on correcting individual behaviour and shaping moral conduct. For example, in analyses of nineteenth century European state formation, while poverty itself was taken to be unavoidable, it was pauperism as a "cluster of behaviours" (indigism, uncleanliness, disease, promiscuity, idleness, rebelliousness) - an extreme and potentially dangerous manifestation of poverty - that needed to be combated (Procacci, 1991). Philanthropy emerged as a technique not only to impart help to those in need, but to reform individual conduct and provide moral guidance. The social thus attends to risk to the collective through institutions and forms 
of practice - philanthropy, schooling and modern domesticity key among them - that constitute responsible, moral subjects.

The social is a concept that encompasses all; in fact it is premised on the idea that no one falls outside its purview (with the exception of those who are defined as outsiders to the collective ${ }^{2}$ ). Those who are to be reformed - the poor, women - do not exist apart; they are part of a whole population/nation/social body (Poovey, 1995:8). Individuals are viewed as representative of the same abstract entity (human nature, homo economicus), as well as other abstract but delimited categories such as national subjects. Moral equivalence of individual subjects is a new form of knitting together, distinct from preceding forms such as patronage/clientage.

This seemingly inclusive principle is not straightforwardly positive; it has egalitarian implications (this was a moral order that could not accept slavery), but also it can and does express itself as a totalizing push to correct and reform alternate ways of being human, to incorporate all into a particular view of a moral collective. Evangelical religion, which arose in the middle class, has a central place in the rise of the social, with its emphasis on incorporating all - because all are "worthy to be saved" (Davidoff and Hall, 1987:25) - into its moral vision of individual salvation. When this evangelism is associated with imperialism, it is evident not only in missionary activities, but also in the emerging tenor of imperial projects in the nineteenth century that sought to bring modernity, civilization, or democracy to those deemed to be in need of such remaking. The social is pervaded by the liberal push to improve or to meliorate. Unlike government and the economy, the social is at the start a realm of intervention; as Valverde states:

\footnotetext{
${ }^{2}$ Though even they may be subject to missionary projects to deliver salvation, or imperial projects to "civilize" or "nation-build."
} 
"There is no question of letting social forces play themselves out - in modern societies there is no invisible social hand" (1991:20). The health of the collective is tended to and risk is minimized through modalities of surveillance, statistics, education, philanthropy, hygiene, medicine, law, modern domestic practice, and various forms of religion emphasizing the free, rational, ethical, subject.

Though the family is often regarded as an extra-political category, the predominant family form built around the breadwinner-housewife dyad and modern domestic practices emerged with liberal economic and political forms; it cannot be treated as a pre-existing or natural category. Working class life is directed toward, and centred in, the home, which needs to be rid of its squalor (Poovey, 1995:120), just as the bourgeois home needs to be rid of the influence of servants on child rearing and household management (Donzelot, 1979:15-16). According to Donzelot, the family becomes a means of turning the working class in upon itself and - particularly in the case of men - away from "the street," and of responsibilizing people to work, save, provide for their children and avoid dependence on others (Ibid:45). Women are responsibilized through the sanctified role of the mother. Women are not only subject to this process of domestication, but they are to reproduce it by domesticating men. In order to keep men focused on the home, women must be similar to men in many respects - they must inhabit a similar cultural world to men, not a separate female one. This includes being educated to some extent where men are, taking sufficient interest in personal grooming, and being aware of modern forms of knowledge and their application within the home. However, this does not mean a blurring of distinctions between masculine and feminine; in fact rather the opposite. Demarcations of gender reinforce the interdependence of 
husband and wife. Notions of romantic love, monogamy and companionate marriage are central underpinnings of this family form, as are emerging notions of separate spheres, public and private, work and home, productive and non-productive or reproductive.

The family is a pre-eminent technique for shaping moral conduct, often synonymous with morality itself, as evidenced in the term "family values." Women are incorporated into the social through the moral subject positions of housewife and mother. The deployment of this moral subjectivity against the potential for disorder accompanying economic and political changes is exemplified in the words of one Indian woman cited in a report recommending the extension of representative government in 1930s colonial India: "As the power passes more and more from the hands of the few to the hands of the many, more and more is the steadying influence of woman needed as the guardian of family life, not only inside but outside the family circle" (cited in Forbes, 2005:69). In handbooks promoting middle class domesticity written by British women in the 1830 s and 40 s, the moral authority of women and "feminine" values, derived from a new maternalism, are presented not only as a protection against the possible chaos of mass politics, but also as a balm to assuage the harsh ethos of the market in which men must compete (Newton, 1994:128-131). The social is thus comprised of cultural forms, techniques, practices and institutions that constitute the moral collective, responsibilize the individual, diffuse pressure on government and counterbalance the effects of the market.

Philanthropy, schooling and the family are key institutions that gave rise to the social in colonial India, as they did in the European contexts referred to by most theorists cited above. However, one key difference between India and Europe in the nineteenth 
century is the absence of poor relief, ${ }^{3}$ and of course emerging ideas of a social body developed in a context in which Indians were subjects not citizens. Liberal culture, with its emphasis on the exercise of free agency, arose in a context in which opportunities to advance politically or economically were severely curtailed. Representative government was not enacted to any significant degree until after World War One. ${ }^{4}$ Evangelical Christianity, though present in India, was not the basis for ideas of moral equivalence, but reformed Islam and Hinduism were. I present my argument that nineteenth century religious reform created notions of an abstract Muslim individual in the process of creating a Muslim collectivity (though not yet a nation) in Chapter Two.

Middle class women's organizations and associations emerged in India alongside organizations demanding greater representation and legal rights beginning in the $1870 \mathrm{~s}$ and 80s. Women's organizations in the nineteenth and early twentieth centuries often referred to themselves as "nonpolitical," despite the fact that their activities had direct bearing on emerging political and economic forms. They identified their mandate as looking after the interests of "women and children," but through this work they extended the reach of schooling, medicine, hygiene and modern domesticity. The claim to being nonpolitical signified the view that the type of politics they were engaged in was different from "male" politics. Its ethos was presented as familial, cooperative, and geared to

${ }^{3}$ In The Making of Colonial Lucknow: 1856-1877, Veena Oldenburg describes the lack of effort by the colonial state to address pauperism and squalor after annexing the state of Oudh to the Raj in 1856: "In Lucknow, where employment opportunities were fewer under the British than in the time of the nawabs, no commitment was made to plow back the vast revenues of Oudh to make up for the dislocations in employment or alleviate the widespread poverty" (Oldenburg, 1984:142-43).

${ }^{4}$ The Government of India Act of 1919 created elected provincial assemblies. Prior to that a few Indians could be elected to provincial bodies by local councils beginning in 1909. There had been some representation on municipal councils and district boards beginning in 1882 (Metcalf, 1984:126). 
collective interests rather than self-interest. In their claim to be united and above selfinterest and competition, organized women presented themselves as representing a single undifferentiated category of "women," a moral force that would be deployed to help construct collective categories of citizenship and nation (Sinha, 2000).

However, the entry of women into social reform was "a development that all but the most radical social analysts deplored" (Poovey, 1995:43). Though the social is often seen as a "softer" side of government, social reform projects were often strongly resisted, particularly where they were identified with the encroachment of centralized state authority. Efforts by women's groups to promote social legislation reforming the family during the Indian nationalist struggle in the twentieth century met with stiff opposition. Women activists reported that while their educational work, medical work and nationalist politics drew support and respectability, the same was not true for social reform legislation (such as legislation prohibiting child marriage), which was very unpopular:

Writing to Jawaharlal Nehru, Kamaladevi Chattopadhyay informed him that the fight against society and its rigid codes was harder than any political fight and also lacked the respectability attached to the political struggle. Dr. [Muthulakshmi] Reddy, well known for the social legislation she had introduced in the Madras Legislative Council, readily admitted that while her medical and educational work was applauded, this was not true for her social reform legislation (Forbes, 1979:19).

Chattopadhyay and Reddy were among the first women to run for seats in provincial Legislative Councils during the 1920s, and Reddy became the first woman in a provincial legislative council in 1927, securing her seat through nomination. In an effort to promote modern domesticity, education and hygiene, she sought legislation to restrict child 
marriage, abolish the system of devadasis, ${ }^{5}$ reduce school fees for poor girls, fund vocational training for poor women, and expand medical inspection in schools.

The mitigation and intervention aspects of the social would exceed the expectations and often the desires of nineteenth century liberal reformers. This was particularly the case with the rise of working class organization and feminism - two movements that advanced forms of collectivism within liberal political formations and whose politics were oriented toward political centralization, state protectionism, an interventionist state and legal regulation. The social would not remain the "depoliticized realm" of classical liberalism as working class organization and feminist politics helped shape a new form of liberalism that incorporated principles of welfarism, universalism in social provision, and positive rights of citizenship (Koven and Michel, 1993; O'Connor, Orloff, and Shaver, 1999:50). Not coincidentally, both these groups came under sustained attack in Pakistan and elsewhere during the 1980s as the social was called into question.

Though the social is often thought of as a lighter side of government, emphasizing feminine values such as nurturing and removed from the "real" centres of power, this view is problematized not only by the degree of opposition to social reform, but also by the degree of coercion that has at times been involved in the social. For example, modern state projects of superseding village, tribe and clan often led to efforts to seize the members forcibly, particularly the youth, of local political and cultural groupings defined as "backward" and to hold them in camps or schools where they were to be reeducated or "rehabilitated." Women have participated in these projects as teachers and social workers alongside police or other coercive state agents. In modernization projects of the twentieth

\footnotetext{
${ }^{5}$ A hereditary class of women dancers attached to Hindu temples.
} 
century, literacy training has often been a method to extend the reach of the state and women have been at the forefront of its often coercive implementation. In Iran prior to the 1979 revolution, one woman who worked in a literacy centre where young women from villages were taught to be "modern" - i.e., not only to read, but to use tables, chairs, cutlery, toilets, showers and beds - reported training a student to sleep in her bed by tying her to it with her chador (Sullivan, 1998). (Puzzled about why her students would disappear at a certain time every evening, the social worker later learned that they were listening to international news broadcasts and contemplating revolution.) Interviews with women who carried out such programs often reveal a belief that despite the hardship imposed on those who were taken from their families and communities, it was "for their own good" (Abu-Lughod, 1998a:9). ${ }^{6}$

Through their involvement in the social, women's organizations have been involved in extending the reach of government. They implement techniques for managing populations and they advocate state laws that play a role in centralizing political power. However, before women played this role in constituting the social, women themselves were constituted as moral subjects through the emergence of modern domestic practice based on a separation of private and public, the male breadwinner and housewife dyad, and the moral equivalence of women and men. It is to this process in the colonial context that I now turn.

\footnotetext{
${ }^{6}$ The alignment of feminism with coercive attempts to remake subjectivities is also evident in British feminists' support for the British empire (Burton, 1994), as well as more recent examples such as the overwhelming support of French feminists for the 2004 law banning the wearing of headscarves by Muslim girls in French schools (Scott, 2007) and the post-2001 support of the American "Feminist Majority" for a war that would supposedly liberate the women of Afghanistan (Hirschkind and Mahmood, 2002).
} 


\section{The "Woman Question" in the Colonial Context}

In the next chapter I provide a more detailed discussion of social reform and efforts to reform women among Muslims in nineteenth century colonial India. In this section I review how several authors make sense of the period of debate around domesticity and women's emancipation in the latter half of the nineteenth century in colonial India. ${ }^{7}$ At this time, there were efforts to restrict polygamy and prohibit child marriage; to enact legal reforms allowing women to obtain divorces and widows to remarry; to change inheritance laws to benefit women; to expand women's education alongside that of men; and in some cases measures were taken against veiling and women's seclusion. These efforts were pursued largely by men at first and then increasingly by women belonging to political and economic elites concentrated in urban areas, elites that did well through employment in the colonial state, professions, commercial activities or land ownership. Social reformers from these backgrounds pursued "modernization" by establishing journals and associations to promote social reform and by founding schools. Public debate about "women's emancipation" was accompanied by an enormous quantity of writing on domesticity, the family and correct conduct for women. Manuals for housewives and didactic novels intended for female audiences, some of which became school texts, instructed women on moral conduct, housekeeping, family relationships, and religious piety. These publications promoted a new notion of family based on companionate marriage and a new middle class woman

\footnotetext{
${ }^{7}$ For debates on domesticity and "the woman question" in South Asia and the Middle East, see edited collections by Abu-Lughod, (1998a), Sangari and Vaid (1989) and Sarkar and Sarkar (2008), as well as Ahmed (1992), Asad (2003:205-256), Chakrabarty (1993), Chatterjee (1989, 1993, 1997), Mani (1998), Malhotra (2002), Sarkar (2001), and Walsh (2004).
} 
skilled in the application of modern science to care of the home and child rearing (which came to be called "domestic science"). At the same time, considerable emphasis was placed in reformist writings on women's religious observances, how they were incorrect, and how they could be made correct.

Four main types of arguments are given to explain the plethora of writing and debate about domesticity during the nineteenth century. In some accounts reformist discourse on the home is identified as an attempt to create a harmonious, authentic or spiritual refuge from the public disruption of colonial rule (Chatterjee, 1989, 1993, 1997; Sarkar, 2001). Alternatively, and somewhat contradictorily, reformers are argued to be reacting to the colonialist's denigration of native culture by emulating the colonizer's domestic culture (Chakrabarty, 1993; Ahmed, 1992). Another approach, exemplified by the work of Lata Mani $(1989,1998)$, focuses on colonial discourse that attempted to define "authentic" Indian tradition through debates about women. A fourth approach emphasizes the permutations of patriarchy and views reform of the family as reflecting attempts to impose a new form of patriarchy within the home (Malhotra, 2002; Walsh, 2004). I suggest some limitations with these perspectives on nineteenth century debates on domesticity and correct conduct for women. In Chapter Two, I will offer a different perspective, suggesting that this period be seen as one of cultural and moral revolution in which women were central rather than marginal, and that changes in domesticity were constitutive of a changing political order.

Noting that explicit debate among reformers about "the women's question" subsided by the end of the nineteenth century with the rise of nationalism, Partha Chatterjee posits that Indian nationalists resolved "the woman question" by making 
women signifiers of an inner/spiritual domain of Indian difference from the west while simultaneously adopting western "material techniques" in an outer/material domain. Chatterjee suggests that by situating the home as a spiritual domain, nationalists were able to modernize the "outer" domain while retaining the home as an inviolate sphere free from western influence. Tanika Sarkar also views the focus of reformers on refashioning home and family in relation to the need for a haven from the external/colonial world. According to Sarkar, domestic manuals produced by Bengali men of the bhadralok (respectable people) in the last decades of the late nineteenth century sought to extol the superiority of relations within the family, particularly between husband and wife, as a contrast to "the world outside." In a context in which men were dispossessed and marginalized by colonial rule, the domestic, particularly the loving wife who builds her life around the husband, became a "critique of alien rule" (Sarkar, 2001:198). Sarkar's analysis allows a greater degree of interdependence of home and public than does Chatterjee's construction in which the two are culturally distinct, a conclusion that contradicts most accounts that demonstrate emerging aspects of cultural sameness of public and private such as "domestic science" and efforts to promote conjugality through harmonizing the educational, linguistic and religious practices of men and women.

One difficulty with the treatment of home as haven is that, rather than a refuge from the colonizer, the middle class home was greatly impacted by colonial administration. According to Anagol (2005), in their focus on the discourse between colonial officials and male nationalists and reformers, social historians of this period have neglected the role of women, particularly their use of British courts, in creating a situation in which the domestic became contested. In the nineteenth century, women were 
using courts rather enthusiastically to obtain divorces, inheritance, alimony and maintenance - thousands of women a year, for example, during the 1880s in Bombay Presidency alone (Anagol, 2005:195). ${ }^{8}$ Court records show that many Muslim women were among those filing suits in courts in the late nineteenth century (Kozlowski, 2008), a period that David Washbrook characterizes as "the great age of civil litigation in India" (1981:670). During the 1880 s and 1890 s, women were also organizing to advocate state intervention within the family to restrict child marriage. According to Anagol, this "wives rebellion" cannot be discounted as a factor in Indian reformers' attempts to prescribe proper wifely behaviour, and their particular emphasis on the need for women to put family interest above self-interest (2005:195-201).

Another approach draws attention to the attempt to fix and specify authentic Indian tradition in colonial discourse. Beginning in the eighteenth century, colonial officials sought to codify and classify Indian tradition in the process of ruling India. The scripturalist emphasis in colonial discourse assumed the hegemony of Brahmanical texts and the submission of all Hindus to those texts (Chatterjee, 1997; Mani, 1989). In her review of nineteenth century debates over the prohibition of sati in India, Lata Mani describes how colonial officials, missionaries and indigenous elites became involved in debates over what constitutes authentic tradition and how, for all three groups, "the reworking of tradition is largely conducted through debating the rights and status of women in society" (Mani, 1989:90). Despite colonial officials' criticism of sati as a practice indicative of the barbarity of Indians, the experience of women themselves was not an issue in colonial discourse on sati as women were "neither the subjects nor even

\footnotetext{
${ }^{8}$ Though courts did not always render judgments that were more favourable to women than those of local councils or panchayats (Anagol, 2005:120-121).
} 
the primary objects of concern" (Mani, 1998:2). Rather, attempts to regulate sati focused on debates over correct interpretation of scripture and the identification of authentic tradition.

Whether nationalist elites are argued to be engaging in debate with colonial officials over "authentic tradition" or trying to protect the home as the locus of indigenous culture free from the colonized public sphere, women are not political actors in these accounts. As Chatterjee argues, "nationalist discourse... is a discourse about women; women do not speak here" (1997:260). Yet, women's journals and writings in the late nineteenth century show the same concerns as middle class men in advocating that women cultivate domestic skills. While, as Mani describes, the debate over sati may have been characterized by a focus on scripture, this cannot be generalized to the totality of discourse taking place around domesticity during the nineteenth century. In the late nineteenth century, women arguing for increased state involvement within the family developed a type of discourse that was not situated within scripture. During the $1880 \mathrm{~s}$ and $1890 \mathrm{~s}$, the discourse of female reformers stressed the need for change in order to promote harmonious relations within the family, not adherence to textual representations of women (Anagol, 2005:202-9). Accounts of the period of social reform demonstrate the growing importance of women as political symbols, but lost is any sense of how women, through their involvement in the newly emerging social spaces of schools, print and publishing, voluntary associations, and later political campaigning and parliamentary politics, took this new moral feminine subject and used it as a platform to fashion themselves as model citizens of the nation state which they proceeded to play a role in creating (Sinha, 2000). 
In other accounts, indigenous elites seek not to preserve the home as an inviolate sphere, separate from the colonized public, but in fact seek to reform it along the lines of European models of home and family. For Dipesh Chakrabarty (1993), nineteenth century Bengali nationalists were taken with European power and ideas of improvement, saw European power as deriving from "European domesticity," and subsequently mounted their own critique in print of the Bengali home, echoing the colonizer's allegations regarding the backwardness of the Indian home and the degraded status of its women. Chakrabarty writes: "As this civilizing-cum-nationalist body of thought proliferated in the second half of the nineteenth century to incorporate influences coming out of Victorian England, the personal and the domestic came to be tied ever more closely to the idea of the nation" (1993:4-5). Victorian notions of order and discipline within the home somehow linked up with nationalist aspirations resulting in a disciplinary regime of domesticity. Though I agree that domesticity and nationalism are linked, Bengali nationalism and its project for remaking the home and women appear as a transfer of ideas in Chakrabarty's account; the colonizers brought "modernity" and its various European thought categories, and nationalists embraced it.

Although her argument applies to Egypt, Leila Ahmed's book, Women and Gender in Islam (1992) is an influential text that makes a similar case with reference to nineteenth century Egyptian social reform. Egyptian reformer Qassim Amin's 1899 book, The Liberation of Woman, "represents the rearticulation in native voice of the colonial thesis of the inferiority of the native and Muslim and the superiority of the European" (Ahmed, 1992:162). Amin's book called for primary education for girls and reform of laws on polygamy and divorce, but put particular emphasis on abolishing the practice 
among women of wearing veils. Ahmed argues that demands to abolish the veil were prompted by the critiques of colonialists, missionaries and western feminists, and she argues that advocates of "unveiling" were western educated men who were ashamed of how they looked in western eyes. Despite the title of his book, Amin was seeking to reform society to emulate the west, and not primarily to liberate women, just as western critiques of the veil were not primarily concerned with liberating women but with denigrating the colonized. For Ahmed, the attack on the veil mounted by Amin, as well as by twentieth century modernizing leaders such as Turkey's Ataturk and Iran's Reza Shah, is:

only intelligible against the background of the global dominance of the Western world and the authority of its discourses, and also against the background of the ambiguous position of men and women of the upper classes, members of Muslim societies whose economic interest and cultural aspirations bound them to the colonizing West and who saw their own society partly through Western eyes (Ahmed, 1992:165).

There is no doubt that European thought had an influence on social reformers in colonial contexts. This is evident, for example, in the considerable effort reformers devoted to translating European texts on science and modern disciplines of politics and economics into local languages. But beyond the unresolved question of what was so attractive about western cultural forms, there are a number of issues that raise problems with these accounts. How did this transfer of ideas take place in a context of limited exposure to European domesticity, and linguistic differences? Not all reformers traveled to Europe, spoke English, or had any direct dealings with colonial administration. For example, the ulama in India avoided contact with colonial administration, courts and schools - and decidedly did not see their economic interests as lying with the west - but as I discuss in the next chapter, many promoted similar views regarding new forms of 
domesticity, emphasizing companionate marriage and the need to educate women in scripture and "domestic science." Nor was the gender discourse of the late nineteenth century limited to colonies. Political elites in Turkey and Iran were among the most ardent reformers, as well as in Egypt where domestic reform predated British occupation.

The notion that European domesticity was transplanted through a process of imitation also assumes that European domestic discourse was uniform and uncontested rather than variable and in flux. British men did not bring their wives to India to any great extent until colonial administration shifted from the East India Company to crown rule and to administration through the Indian Civil Service (ICS) beginning in the 1850s. According to Steven Patterson (2009), the model of masculine authority underwent a radical shift at this time. To the "noble army officer" of the East India Company, the new middle class ICS officer was weak and ineffectual, both physically and intellectually. The previous Anglo-Indian elite referred to the new men derisively as "competition wallahs" (staffed through competitive exams introduced in 1853) and questioned whether they had what it took to rule India (Patterson, 2009:79-96). The form of masculinity associated with the ICS officer was a duller, sterner, more Spartan masculinity that frowned on the idleness, ostentation, flagrant displays of titles, carousing and luxury-enjoying ways of the Company men. The middle class administrator of the ICS established his authority through "good character," hard work, and participation in athletic games to establish a claim to physical vigor and manliness. Though criticized by the previous Anglo-Indian elite for bringing their wives to India, the fact that the new administrators did so, and in return disparaged the Company men for cohabiting with Indian women or having Indian mistresses (Sarkar, 2008:32-33), is indicative of both the indispensable role of the wife in 
the middle class household and in projects of rule based on racialized notions of nation/moral collective, and the close association between new forms of political authority and new forms of domesticity.

But the new administrators did not admire Indians who shared their middle class habits. The derisive term for the Indian civil servant, " $b a b u$," connoted the same critique of character and competence that was leveled against the "competition wallahs" by the previous Anglo-Indian elite (Patterson, 2009). During the latter half of the nineteenth century, after widespread rebellions in 1857, and despite its bureaucratic model of administration, the Raj cultivated a strongly monarchical model of political authority in India. It called its head of government in India a "viceroy" rather than a Governor General. It courted the leaders of princely states within India, "heaped" them with titles and used them as a "bulwark against Indian nationalism" (Patterson, 2009:92-93). ${ }^{9}$ It resurrected the Mughal practice of the durbar - a type of public audience at which gifts and honours are bestowed on local notables for their loyalty (and denied to those out of favour) (Ansari, 1992; Cohn, 1983). It dressed its Indian soldiers in showy Mughal-type uniforms rather than the western clothing they had worn before (Cohn, 1983). It distributed land titles to create loyal gentry in various regions of India and formulated laws to prevent the dismemberment of landed estates through succession or indebtedness (Gilmartin, 1981, 1988; Metcalf, 1979; Talbot, 1988). Meanwhile, the denigration of India's inhabitants intensified as the British orientalists of the late eighteenth and early

\footnotetext{
${ }^{9}$ In addition to provinces under direct administration, British India contained hundreds of "princely states" that retained control of their internal affairs but recognized the "paramountcy" of the British crown (Copland, 1991). It should be noted that some of the heads of princely states themselves were reformers or patronized reformist causes such as schools or publications (Lambert-Hurley, 2004; Mayaram, 1997).
} 
nineteenth century, who, for example, formulated notions of India's "lost glory" and Aryan past, were replaced over the course of the nineteenth century by missionaries, travelers and liberal reformers who offered evangelical and utilitarian discourses that stressed the backwardness, barbarity, and racial inferiority of India's inhabitants (Chakravarti, 1989:29-38; Mehta, 1999; Sarkar, 2008:38-42; Viswanathan, 1989). In this regard, rather than viewing the adoption of middle class domesticity by Indian reformers as mimicry of the colonizer and reproduction of the colonizer's critique of Indian culture, it is also possible to see it as both a perceived route to supersede the Raj and a critique that was leveled specifically against the culture of princes, warriors and nobles. For middle class Indians as well as Anglo-Indians, domesticity was part of a project of rule that proceeded through more complex processes and for more complex reasons than mimicry of presumably authoritative and monolithic western discourses. ${ }^{10}$

As well, social and legal reforms were not implemented in the coherent and uncontroversial way that is often portrayed. For example, the emergence of modern schools was characterized by decades of contestation among reformers over the effect of schools on gender and class relationships as well as concern with their linguistic and religious or sectarian character. Nor did reformers always grasp fully the implications of their reforms, or what they would precipitate. Muslim reformers in late nineteenth century India -whether liberal or orthodox - advocated women's rights to a share of inheritance as specified in the Quran, a challenge both to "feudal" and "tribal" authority that I discuss further in Chapter Two. But in the Mughal state, wealth had inhered in the

${ }^{10}$ Tanika Sarkar (2001) has critiqued the work of the Subaltern Studies collective, to which both Partha Chatterjee and Dipesh Chakrabarty belong, for, among other things, a generalized treatment of "nationalists" as a uniform category of western imitators (see also Bannerji, 2000; O’Hanlon, 1988; Sarkar, 1997). 
produce of land and "moveable property" (Kozlowski, 2008:329). The idea of land itself as property was relatively recent, having been introduced by the British (Cohn, 1983:173). Kozlowski observes that in their writings promoting property rights for women, Muslim reformers in India did not appear to conceive that women would begin to demand shares of houses and land, though many did exactly that, initiating law suits in nineteenth century Anglo-Indian courts and receiving portions of estate lands (Kozlowski, 2008:333-35). Reforms such as divorce and inheritance laws that weakened local political institutions such as panchayats or village councils and promoted centralized government based on a unified legal system also gave rise to a category that reformers did not necessarily anticipate: independent women.

A final suggestion made in writing about the woman question is that nineteenth century debates around domesticity represented an attempt to create or to recreate the patriarchal family (Didur, 2006; Malhotra, 2002; Walsh, 2004). Many domestic manuals for women were written at this time spelling out in detail how good women should conduct themselves, but also criticizing women for innumerable transgressions and incorrect behaviours. Walsh sees in this disparagement of women a concern to break up the homosocial networks within which women lived their lives for the most part and to increase the power of husbands over wives. As I discuss in the next chapter, reformers did attempt to change gendered arrangements within the family, and their writings did criticize, and seek to radically reform, women's conduct. But reformers also propagated a new discourse in which women and men were seen as morally equivalent, and the condemnation of women's habits existed alongside the creation of a new ethical subjectivity for women. Both men and women were also involved in creating a discourse 
at this time that emphasized women's "rights" in the family and in the public sphere. I am not suggesting that this was an age of liberal equality for women, but that an emphasis on the attempt to create a new patriarchy does not shed light on why this project was pursued at this time, nor how such a project fits with changes advocated by male reformers that appear to loosen the hold of patriarchs over women, such as divorce and inheritance laws, and with a discourse that emphasized the equal moral status of women and men. Nor does it account for changes in masculinity accompanying changes in femininity, or why the same technologies that apply to the public world are to apply also to the domestic, such as science, reason, law, medicine and hygiene.

The "woman question" was central in political debate in India during the nineteenth century, expressed in terms of public debate over women's education, purdah (women's seclusion), polygyny, sati (widow immolation), and child marriage, and in terms of active efforts to shape the moral conduct of women. British rulers and Christian missionaries used characterizations of backward Indian customs to justify projects of colonial rule in India (Mani, 1989). But debates among indigenous leaders over practices involving women were not merely a reaction to colonial discourse. They were centrally concerned with shaping the character and knowledge of women, and with the creation of a middle-class, educated housewife (Metcalf, 1994). As Kandiyoti writes:

Women's illiteracy, seclusion and the practice of polygyny were not denounced merely because they so blatantly curtailed the individual human rights of one half of the population, but because they created ignorant mothers, shallow and scheming partners, unstable marital unions, and lazy and unproductive members of society (1991:10).

There was concern on the part of reformers in many countries at this time with practices negatively impacting women; a concern that stemmed from the new forms of self, of 
family and of proper womanhood central to newly emerging notions of state and nation. In the next section, I briefly discuss how women played a role in furthering modern domesticity and in creating the nation through a politics of the social.

\section{The Contribution of Social Feminism to Nationalism}

As Chatterjee (1997) observes, explicit debate about the conduct of women began to subside around the turn of the twentieth century. A predominant theme in accounts of the period of heightened nationalist struggle in the twentieth century is that women became "constituencies" to be mobilized in nationalist struggles led by men or were "granted" rights in order to secure their support for political agendas set by male elites. For example, in India, nationalist support for women's suffrage is attributed to attempts to secure support among women for the nationalist struggle and to appear more advanced than the British in light of the latter's own suffragette movement (Liddle and Joshi, 1986:35-36). But women played a more central role than as a constituency to be appealed to, or as symbols in discursive battles among elites. Liberal or social feminism, in articulating a platform pursuing the interests of mothers and children, created a uniform category of "women" whose interests as women were said to be the same for all. This category and social politics served the nationalist cause against the interests both of minorities and colonial authority.

While Chatterjee contends that there had never been a women's suffrage movement at any point in the nationalist struggle (1997:257), Forbes (1979) contradicts the notion that suffrage was simply "granted" to women. She describes the efforts of women's organizations to secure the franchise for women beginning in 1917 when British officials toured India to gather information prior to formulating a new constitution 
for British India. When the franchise was subsequently denied to women in the Government of India Act of 1919, women's organizations petitioned and lobbied each provincial assembly for the franchise and, over the next decade, propertied women were enfranchised in all provinces. Women lobbied again during further constitutional reform talks preceding the Government of India Act of 1935 which did enact the franchise for women on the same basis as men. Subsequently both independent India and Pakistan would include universal adult franchise in their new constitutions.

But more revealing than the supposed ease with which Indian women's organizations argued their case for the franchise with Indian politicians were issues around who should be franchised, and whether there should be reserved seats in legislative bodies and special electorates for women and minority communities. From this perspective, it is apparent that the arguments of women's organizations in support of the franchise were not aimed at gender equality so much as at furthering the notion of a single, undifferentiated, national subject.

Though some women advocated reserved seats for women, at least as a temporary measure to create acceptance for the idea of women in parliaments and to attain some small level of female representation, the three major Indian women's organizations were uniformly opposed to reserved seats by the $1930 \mathrm{~s} .{ }^{11}$ This is despite the fact that reserved seats increased the number of women in parliaments compared to general seats, for which women were much less successful both at being nominated by political parties and at being elected. This opposition to reserved seats was partly because of the association of

\footnotetext{
11 These were the Women's India Association (WIA) formed in 1917, the National Council of Women of India (NCWI) formed in 1925, and the All India Women's Conference (AIWC) formed in 1927.
} 
women's groups with Indian National Congress leader, Mohandas Gandhi, who actively courted women activists but encouraged them to engage in certain sanctioned protest activities (discussed further in Chapter Two), rather than concern themselves with petitioning the government for political rights such as the franchise (Forbes, 2005:67). Gandhi was opposed to reserved seats both for women and minorities (Muslims, Sikhs and Dalits or Untouchables). But the opposition to reservations was also because the primary objective of the major women's organizations was social reform, not gender equality. For this objective, having more women voting and more women in legislatures was not as important as having the right women voting and the right women in legislatures (Forbes, 2005:63-76; John, 2000). According to Forbes, "the records of the women's organizations are full of memos about the importance of having the right kind of woman in office" (2005:75): in other words, middle class, urban, educated wives and mothers, preferably active in women's organizations. Women's organizations advocated various ideas to achieve the right type of female electorate, such as extending the franchise only to urban women as "enlightened" people were more likely to be living in urban areas. This was a reflection of their lack of confidence in the colonial state's loyal centre among rural property owners, and their presumably uneducated wives who would not understand the benefits of reform (Forbes, 1979:18). There were other smaller, local and regional women's groups that disagreed with the all-India groups and favoured reservations, but they too were not interested "in bringing women unlike themselves into politics" (Forbes, 2005:76).

Nevertheless, the major women's organizations insisted that they spoke for all women and that women's social politics was not characterized by the divisiveness and 
communalism of male politics. In the very act of positing a category of "women," or an overarching "sisterhood," feminism contributed to the universalizing project of liberalism according to Mrinalini Sinha who writes: "The liberal feminist commitment to the 'unity,' and underlying sisterhood, of women supplied a concrete example of the modern 'neutral' universal citizen whose preexisting regional, religious, and caste identities could be bracketed in the public sphere" (2000:634). The service women were doing for the ideal of the universal citizen, irrespective of region, caste, religion, or other identifications, is revealed most disturbingly, Mary John argues, in the consequences that their opposition to reserved seats had for the political rights of Dalits (2000:3827).

Gandhi's opposition to reservations related to concerns about what the identification of Dalits as a separate electorate would do to a unified concept of "Hindu" (John, 2000:3825-26). In their opposition to reserved seats, the all-India women's groups were pitting themselves against minorities, in part wittingly because "'religious and minority rights' were perceived as working against social reforms that would benefit women" (Forbes, 2005:73), and also unwittingly in that women's opposition to reservations was used by Gandhi and others to counter the claims of religious minorities for special political rights (John, 2000:3828; Sinha, 2000:636).

The social reform agenda of women's groups furthered nationalist interests not only in countering the political claims of minorities, but also in highlighting the role of the colonial government in blocking "modernization." In 1928, women's organizations waged a campaign for the passage of the Child Marriage Restraint Act to raise the minimum age of marriage for boys and girls, a battle that Sinha (2000) credits with helping male politicians in the Central Legislative Assembly comprehend the nationalist 
significance of social reform legislation. Though British officials were eager at this time to malign Indian culture - particularly its treatment of women - in light of challenges from Indian nationalism and growing international criticism of empire, in a contradictory move they also tried to block the passage of social reform legislation to avoid upsetting the colonial state's conservative loyalists. Sinha suggests that the efforts of women's organizations helped parties such as the Indian National Congress and the All India Muslim League comprehend how the legislation would position them as modernists and embarrass the empire in the eyes of the world.

Women's groups developed a range of political tactics during their campaign for the passage of the Child Marriage Restraint Act that they would continue to prefer in subsequent decades over direct involvement in electoral politics. Involvement in male politics was something that would hinder their social work, in part because it might threaten government patronage of girls' schools, but, more generally, involvement in the male dominated political sphere would damage the focus on the social. Eventually women saw the usefulness of having some of their members elected in order to sponsor legislation, but their focus remained on a range of tactics other than electoral politics that promoted a social reform agenda, including picketing outside legislatures or politicians' homes, lobbying leaders, holding public meetings, passing resolutions, and publishing newspaper and journal articles. There was a strong focus on law. "Throughout the 1930s women's organizations formed legal committees, undertook studies of the laws, consulted with lawyers, published pamphlets on women's legal status, and encouraged legislation designed to improve women's position" (Forbes, 2005:22). During World War Two, a debate arose within the All-India Women's Conference regarding whether to 
boycott parliament as Congress was doing. Once again, they prioritized social reform with their decision to continue working with the government to secure family law reform. Not merely beholden to male nationalists, women's groups often preferred to supersede electoral politics and deal directly with "the state," indicating their profound support for centralized political authority as a means to shape the social. Middle class women's organizations avoided politics, even declared themselves non-political in their constitutions, but in fact their social reform agenda helped to fashion the liberal nation state (Sinha, 2000:634) by furthering the notion of the universal citizen, by placing an emphasis on law and individual rights, and by challenging power blocks that opposed liberal government.

\section{Conclusion}

In this chapter I have argued that, rather than being excluded from liberal government, women have played a central role in liberal government and in liberal state formation through their position and role in the social. I suggest that theories of liberal modalities of power have generally overlooked changes to domesticity as part of a moral and cultural revolution accompanying liberal state formation. Analyses of the nineteenth century "woman question" in India also overlook some fundamental aspects of cultural change during this period, and have tended to see women as marginal to rather than central in these debates. I suggest that this period was a moral revolution - one of making women moral, and of establishing relations of moral equivalence between women and men that were foundational to emerging movements of liberalism and nationalism. Through their involvement in the social, women have furthered notions of the modern family, which, rather than being set apart from the operation of power, is a fundamental 
site from which power is exercised in liberal rule - a fundamental site for responsibilizing individuals and promoting practices that reproduce not only the individual family, but the social whole. I provide an example of organized women's efforts to create the social in twentieth century India. I will describe further in this thesis how women played a continuing role in constituting a social whole through, for example, efforts to spread health technologies, responsibilizing women to think of their lives as being in aid of the health of the nation, furthering conjugality, and helping poor women to live "respectable" lives through literacy, vocational training, and family planning. First, however, I discuss Islamization in nineteenth century India, and its role in creating the social. 


\section{Chapter Two \\ Social Reform and the Rise of Muslim Nationalism, 1850-1947}

\section{Introduction}

In 1940, the All India Muslim League articulated the demand for "Pakistan," a separate nation of Muslims in the Indian subcontinent. No such understanding of Muslims as a nation existed in India a century before (Hardy, 1972). Various interpretations have been offered for the origins of Muslim "separatism" over this period. These include analyses that focus on the high level politics of negotiations and constitutional talks (Jalal, 1985; Hasan, 1993), the role of the colonial state in encouraging a view of Muslims as homogeneous and unified (Hardy, 1972), characteristics of the public sphere under colonial rule (Freitag, 1989), ideas and values derived from Islam itself (Robinson, 1974; Shaikh, 1989), efforts by all-India politicians to break the power of provinces in the colonial system of political representation (Page, 1982), and the impact of nineteenth century colonial policy on the Muslim "service gentry" and Hindu commercial groups that emerged from the Mughal empire (Bayly, 1983). The emergence of Muslim nationalism is also linked to a movement known as Islamic Modernism (Ahmad, 1967; Masud, 2009; Moaddel, 2005; Rahman, 1982) that emerged in the nineteenth century seeking to harmonize Islam with liberalism, rationalism and science.

I do not seek to provide an explanation for Muslim "separatism" here, but to describe social and religious reform movements in the nineteenth century that sought to create, and to incorporate women into, a Muslim subjectivity, and how these forms of subjectivity articulated with political movements in twentieth century colonial India. This 
process was not unique to Muslims - a parallel process was under way among Hindus, and India's other religious communities. I focus on the process as it arose among particular groups of Muslims in north-central India, and I refer to this process as Islamization. The period covered here roughly extends from the beginning of direct crown rule that replaced rule by the East India Company during the 1850 s, until the last years of colonial rule prior to independence in 1947. The first part of the chapter focuses on social reform beginning in the second half of the nineteenth century. I then discuss how the new reformed woman became involved in the politics of nationalism during the first half of the twentieth century, until independence in 1947, as well as the emergence of Islamism, which opposed women's increasingly public, political role.

\section{Religious and Social Reform in Nineteenth Century India}

Concurrent with similar developments in other parts of the world, movements of religious and social reform abounded in nineteenth century India. They shared common features, including a scriptural understanding of religion, the call to purify religion to remove syncretic and customary influences and accretions, and the centrality of the modern, rational, ethical subject in religious discourse. These intellectual currents found new methods of reaching and influencing larger audiences, particularly through print technologies and modern forms of schooling. A new religious understanding was being forged based on knowledge of scriptural precepts and the need to reform the "inner self," at times referred to as a "Protestantization" of the diverse traditions of South Asia, reformed and consolidated under the rubrics of Hinduism, Buddhism, Sikhism and Islam (Jones, 1989: 213-214). 
Movements of religious reform interacted with, but were not simply a product of, colonial rule. Many Muslim reformers of the nineteenth century were influenced by the Delhi scholar, Shah Wali Ullah (1703-63), who sought to purify Islamic practice and rectify the perceived moral decline of Muslims through greater knowledge of, and adherence to, the key texts of Islam: the Quran, Sunnah and Hadith. ${ }^{1}$ However, nineteenth century religious reform movements occurred in a context of classifications that were developed to define religious or linguistic communities formally, and statistics that were gathered to measure their numeric strength for purposes of furthering administrative control and securing British rule (Cohn, 1996). Enumeration was a modality of state control in Mughal India as well (Guha, 2003); however, the widespread melding of religious and social reform with the notion of population - counting adherents of a specified religion while simultaneously delineating their religious practice - was novel.

Most Muslim reformers in India came from two elite groups: the ashraf or aristocracy (singular sharif), and the ulama. The former group, composed of descendants of the conquerors and rulers of medieval and Mughal India, or those who had served the Mughal state, sought to maintain a position of power and status within the colonial state. Anglicized or "westernized," they often wrote in English, emulated European personal manners, and promoted European forms of knowledge, including science, mathematics, engineering and medicine. These reformers were concerned with the active interpretation of religion to suit "modernizing" societies, and the creation of a rational and modern Islam, suitable to a secular, constitutional democracy. They emphasized individual values

\footnotetext{
${ }^{1}$ Sunnah are the practices and precepts of the Prophet Mohammad. Hadith are recorded accounts of the statements of the Prophet.
} 
of thrift and frugality in light of changing economies, "shifting patterns of patronage" and the emergence of a "middle class method of rule" within the colonial state (Minault, 1998:41; Patterson, 2009).

The ulama also held positions in the Mughal state as advisors, educators, and judges, and they oversaw Islamic systems of charity. Unlike reformers from the professional and administrative elite, the ulama wrote and communicated in Urdu, and addressed themselves to an Urdu-speaking public, which was by no means a large group - essentially composed of the ashraf and the religious establishment of north-central India. They did not interact directly with the cultural discourse of the colonial rulers, or institutions of the colonial state. Their lives were heavily impacted by the advent of British rule. In the late eighteenth century, British colonialists began a process of attempting to codify Hindu and Muslim law. Colonial officials saw India and its way of life as "timeless" and invariant, not changeable and subject to multiple interpretive perspectives, and assumed that through codification and identification of authoritative texts, Hindu and Muslim law could be applied by English judges. They searched for authoritative texts, relying on the assistance of Hindu pandits and Muslim maulvis, but became frustrated by the varied interpretations of their indigenous experts, which they saw as resulting from the "venality and ignorance" of the latter rather than problems inherent in the exercise itself (Cohn, 1996:71). "Local experts" were gradually excluded; after 1864 they were rarely consulted (Anderson, 1990, 213; Washbrook, 1981:673). In attempting to base authority on the traditions of the inhabitants of India, the British radically transformed understandings of what those traditions were. The introduction of British courts and systems of jurisprudence, combined with the codification of "Anglo- 
Muhammadan Law" transformed shariat "from a flexible system in which individual religious scholars treated each question that came before them as unique into a codified system based on precedent" (Ewing, 1997:46). The "Anglo-Mohammedan law" developed by the British was, Zaman writes, "decidedly not the 'ulama's legal tradition but a hybrid of certain legal classics and English common law" (2002:25). The ulama found themselves marginalized in their own domain as experts, judges and advisors to rulers in the Islamic tradition; they subsequently avoided the Anglo-Indian court system and encouraged other Muslims to do the same. In the nineteenth century, they were faced with finding new ways of situating and supporting themselves as scholars of Islam. They did not possess the local popular authority, and often landed wealth, of the Sufi pirs (spiritual guides or saints) who dominated rural Islam.

Both the ashraf and the ulama were predominantly urban, with little involvement of rural landed elites (except for some absentee landlords) or of rural religious leaders. The ulama were exclusively male, and other reformers were predominantly male, though in the late nineteenth century more women began to be involved in reformist activities such as publishing, education, and voluntary associations that met to discuss religious texts, debate social issues, and carry out projects such as charitable works and the establishment of schools. The ashraf and ulama together constituted a small literate class of Muslims, both seeking in their own way to shape a modern Muslim self embodying such traits as rationality, self-discipline and frugality: a self preoccupied with events in this world and not given over to immoderate emotional states, including excessive devotion to the divine. They promoted new understandings of religion that were opposed to forms of religious practice characterized by hierarchy, conceptions of spiritual 
inequality and the need for saintly intermediaries (Gilmartin, 1988:4). They were also opposed to the nominal Muslim; for reformers it was necessary for individuals to participate in practices and acquire knowledge formative of a Muslim identity (Lelyveld, 1996). This identity was defined in a particular way: religion was increasingly understood as scriptural and legal, concerned with law, morality, jurisprudence and adherence to strictures derived from texts. Knowledge of scripture was important for its place in creating a moral subject for this world. This Islam was not a matter of union with the divine or of finding the divine within oneself; nor was it concerned with miracles or prayers for intercession. Rather, the Islam advanced by nineteenth century reformers emphasized rules for right and wrong conduct in the temporal world.

Newly emerging ideas of Muslim identity did not centre on Islamic notions such as the ummah (the community of all believers), but rather they emphasized a romanticized notion of sharif (noble) Muslims. Like projects of bourgeois class formation occurring elsewhere, newly emerging ideas of Muslim identity involved strong projects of race and gender formation. I will come to the latter below, but with regard to the former, new notions of Muslim identity focused on a racialized hierarchy of Muslims topped by the imperial rulers and conquering "warrior races" of the subcontinent, as well as those who claimed descent from the Prophet Mohammad (Syeds) or from the companions of the Prophet (Shaikhs) - in other words, the often cited quartet of Mughals, Pathans, Syeds and Shaikhs (Hardy, 1972; Metcalf, 1990:25). ${ }^{2}$ This emphasis on the notion of the sharif - with its connotation of warriors who conquered India and aristocrats

${ }^{2}$ Despite their designation as a "warrior race," Pathans or Pashtuns led by Abdul Ghaffar Khan were strong supporters of Mohandas K. Gandhi's non-violent anti-colonial movement beginning in the 1920s (Metcalf, 2009:102-3). 
who ruled it - was far from inclusive of all or most Muslims. In particular, it conferred greater respectability on those who claimed this heritage compared with those who were seen as indigenous converts to Islam, including the largest group of Muslims in India, the Muslims of Bengal.

Processes of race formation among Muslim, as well as Hindu, reformers were aided by British theories of race. After the most serious challenge the British Indian empire ever encountered, the widespread rebellions of 1857 (said to have started among Bengali soldiers in the British Indian army and hence often referred to as the "Mutiny of 1857 "), the British pursued a policy of recruitment from what they defined as the "martial races" of India. Recruitment centred on north-central and north-west India, and regiments were organized according to caste and ethnicity. Linked to projects of British colonial race formation, the identification of groups as martial races was variously attributed to the cooler climate of the north-west, descent from Aryan races, or a greater "Europeanness" in physical appearance or personality. Metcalf points out that the racialized Other in this discourse was the Bengali: "["Martial races"] were what the Bengali was not" (1995:127). As I discuss in Chapter Three, martial race discourses developed after 1857 to justify continued British rule, and as a means of categorizing and administering India, took on an extended life in the post-1947 Pakistan military.

Both groups of reformers, the ashraf and the ulama, opened educational institutions to provide training in the new approaches they advocated. Literacy and education were central to the emphasis they placed on personal knowledge and awareness of religious laws and scriptures. Many schools teaching modern disciplines, as well as Islamic schools (madrasahs), were opened at this time. The two most famous were the 
Mohammadan Anglo-Oriental College, established in 1875 in Aligarh and the Dar alUlum Madrasah in the city of Deoband, founded in 1867. The two groups of Muslim reformers, the ashraf and the ulama, became known by the towns, both in the province of Uttar Pradesh, where their schools were located: Aligarh and Deoband. ${ }^{3}$

Intended to facilitate entry into elite positions within the British administration, the college at Aligarh was modeled in part on Cambridge University in England and recruited a principal from Cambridge. The teaching styles and organizational structures of Deoband also revealed the influence of British educational models with departments and examinations; and with an emphasis on the application of individual reasoning, logical argument, and the free exchange of ideas (Metcalf, 1982). Both types of schools were oriented toward teaching a reformed Islam, promoting individual knowledge of the teachings of Islam, and producing a Muslim middle class. Other schools were established throughout North India based on the models of Deoband and Aligarh.

Muslim reformers were heavily involved in publishing as well, including journals, guidebooks for personal religious practice, and pamphlets outlining main principles. These were to inform Muslims of correct practice and provide a means of popularizing scriptural knowledge of Islam. The ulama, who had previously provided advice mainly to political rulers, were now seeking direct access to respectable Muslims in order to shape their practice and belief. The changed usage of fatwa (rulings based on interpretations of shariat) is an example of the new role of the ulama. Whereas these had formerly been given as court-based rulings on Muslim jurisprudence, fatawa were now compiled and published to guide Muslims in their daily lives (Metcalf, 1982:52).

\footnotetext{
${ }^{3}$ There was a plethora of smaller groups not associated with Aligarh or Deoband but engaged in a similar process of religious and social reform.
} 
Sayyid Ahmad Khan (1817-1898), the founder of the Aligarh college, published extensively, including a journal entitled The Social Reformer. Like the Deobandi ulama, Sayyid Ahmad Khan emphasized individual moral conduct, but without reference to historical schools of interpretation of shariat. He felt that the purpose of engaging with the texts of Islam was not the endless exegeses of the ulama, but to derive main ethical principles to guide people in their daily affairs. Sayyid Ahmad Khan sought to develop a rationalized, individualized Islam that was consistent with western forms of knowledge, and he was among a number of reformers who established "Scientific Societies" to propagate knowledge of modern science and translate English scientific texts into local languages (Arnold, 2000:157).

\section{Reforming Women}

New understandings of "religion," racialized class formation and the concern with new forms of knowledge and schooling among the ashraf and ulama were connected to an overarching moral project. The definition of sharif was also undergoing a change during the latter part of the nineteenth century, from signifying those born of noble ancestry, to those who were of "good character: honourable, upright, cultured and respectable" (Minault, 1998:5). Modern notions of individual responsibility were on the rise. Despite the aristocratic origins of many upper class reformers, there was a critique of traditional wealthy classes and the wasteful "nawabi" lifestyle previously common among them. This critique was often directed particularly at women who were symbols of backwardness and wastefulness, and whose customs and observances were argued to have no basis in scripture (Minault, 1998:5). Unlike Islamist movements that emerged in the first half of the twentieth century, the ulama did not employ a critique of western 
women or women of other religious or national communities. Their focus was "the 'enemy within': the unreformed, uneducated woman who did not know Islamic doctrine, was caught up in expensive and corrupting ceremonial practices and handled badly the responsibilities of her everyday life" (Metcalf, 1994:6). Yet reformist discourse also emphasized love and monogamy and extolled calm, harmonious interaction. For a man to be satisfied with his wife, it was preferable that she possess some modern education and the ability to interact in the company of men. Reformers endeavored to promote the counterpart to the civilized, modern man, and, as with middle classes elsewhere during the latter half of the nineteenth century, "The family form most suited to deliver this modernity was the nuclear family, based on stable monogamous unions, the free choice of spouses and companionate and egalitarian relationships among family members" (Kandiyoti, 1991:10).

The link between emerging understandings of woman as mother and housewife, new notions of companionate marriage, and new political forms such as population and nation is illustrated in a famous poem "Chup ki Dad" (Homage to the Silent) by the poet and reformer, Altaf Hussein Hali (1837-1914):

Oh mothers, sisters, and daughters, The honor of the world Comes from you. Countries' populations, And the greatness of nations, Come from you.

$\cdots$

Companions of your husbands, And comforters of your sons, Without you all homes are deserted; The blessings of the entire home Come from you. (cited in Minault, 1986:141-142) 
In the following discussion, I focus on three aspects of this gendered debate that were central in Indian Muslim politics during the late nineteenth and early twentieth centuries: women's education, purdah, and shariat. I argue that women's education, reforming the practice of purdah, and the particular way that shariat was codified to become personal status or family law, all relate to efforts to create the modern family and the middle class woman as part of the class and gender projects involved in the creation of a "Muslim polity" (Devji, 2008) in the context of British rule.

\section{Educating Women}

The ulama in India advocated education for women as essential to changing the personal religious practice of Muslims and advancing standardized notions of Islam (Minault, 1998). Muslim professional men also promoted women's education, insisting that education would make better wives, mothers and Muslims (Ibid). Women's journals began appearing in the 1880 s to promote education for Muslim women, and to change strongly held popular perceptions that educated women were neglectful housewives. The editor of Punjab's first women's magazine, Maulvi Mehboob Alam, explained in the magazine's first issue that education for women was needed to promote harmony between men and women, allowing them to work in tandem (Saiyid, 1998:53-54).

The all-male Mohammadan Educational Congress made a formal statement supporting women's education in 1886 . Debate went on for years in print and in various associations concerning women's education. Issues discussed included whether girls should be taught at home or in schools, how purdah could be maintained in the process, what subjects should be taught, and how respectable families could be persuaded to send their daughters to schools. Though Sayyid Ahmad Khan complained that women's 
ignorance, superstition and lack of scientific knowledge meant that "the men of

Hindustan have to spend their lives with savages" (cited in Saiyid, 1998:66-67), he was against hasty moves to educate women. Sayyid Ahmad Khan saw education as clearly tied to improving the employment prospects of Muslims in India; in this regard, while education could improve the status of men, he feared it could worsen that of women because of the mixing of social classes he saw in government schools, and the threat this posed to the elite status of sharif Muslims. In an 1894 lecture he stated:

There is no doubt that I disapprove of the establishment of schools where girls congregate in veils and 'chadars' irrespective of the family or social class they belong to...I urge upon respectable families to come together and arrange an educational system for their daughters that is patterned on traditional lines. No one from a respectable family can dream of educating his daughter to work in a telegraph office or the post office (cited in Saigol, 1993:199).

In fact, many "respectable" Muslims were reluctant to send their children to schools where they would be exposed to, in the words of one Aligarh proponent, "the vulgar people" (Lelyveld, 1996: 92). Sayyid Ahmad Khan also preferred that a generation of men be educated first to avoid the prospect of marital conflict (Aftab, 2005:80; Mumtaz and Shaheed, 1987:48). By the twentieth century, however, the issue seemed to resolve itself in favour of formal schools, as the demand was too great to educate women at home (Minault, 1998:215). The demand increased in part because of the shortage of educated women to provide compatible wives for the male graduates of Aligarh and other modern schools in a context in which "Such education was simultaneously evidence of sharif status and a way to maintain or even enhance that status" (Minault, 1998:264). As well, women themselves began to establish girls' schools and to advocate for women's education through journals and associations to the extent that, by 1903, the Mohammadan Educational Conference was forced to accept female members. In the late nineteenth and 
early twentieth centuries, middle class women formed associations throughout India to advocate for female education, establish schools, and provide literacy and vocational training for urban women.

In addition to formal schooling, print and publishing were also important methods to promote the reform of women. Instructive literature for women included cookbooks, home management guides, and didactic novels. The latter would demonstrate such themes as the evils of laziness and procrastination, or feature two female characters: one good and respectable, and the other displaying the faults that reformers wished to correct. This was the first time that women became protagonists in Urdu literature (Saiyid, 1998:72), and was in contrast with classic Urdu literature which saw no use for teaching morality to women (Naim, 2004:140). In the reformist literature published in the 1870 s and 1880s, family life was portrayed as complex and there was much work for women to do: relations within families had to be managed, husbands needed to be counselled and overseen to ensure their career success, children had to be educated and their characters shaped, and fortuitous marriages needed to be arranged for children and siblings to maintain the respectability of the family and to ensure continued domestic harmony. Such important tasks could not be accomplished if women were behaving as reformers complained they were: quarreling endlessly, spending extravagantly, wasting time on useless rituals, and generally driving their husbands to seek the more refined company of courtesans. $^{4}$

Didactic novels also illustrate the new feminine ideal put forth by the movement for women's reform: the passive, self-sacrificing, stoically silent and suffering mother

\footnotetext{
${ }^{4}$ The latter concern was specifically alluded to by Hali (Minault, 1998:48).
} 
figure (Devji, 2008:385). Women exemplifying the "feminine" attributes of patience, obedience, and modesty were contrasted to argumentative, impulsive women. Devji's contention that reformist discourse on women was a "polity-building" movement is supported by the fact that this ideal woman-as-mother became the enduring symbol and model of womanhood espoused by nationalist politicians in the twentieth century and the basis upon which "respectable" women entered politics. For reformers, the new ideal of housewife and mother was not a private, apolitical one: these were publicly-minded women who thought about the outside world in which their husbands and sons had to compete and succeed, and became agents for the spread of new practices of home management, hygiene and child rearing.

The most famous guidebook for women was entitled Bihishti Zewar (Heavenly Ornaments), written by Maulana Ashraf Ali Thanawi (1863-1943), who was associated with the Deoband madrasah. Published in 1905 - and still in print a century later Bihishti Zewar became enormously influential as a comprehensive guide on how to be a Muslim woman. It was originally published in twelve sections, covering such topics as reading and writing; how properly to manage a household; proper and improper behaviour in women; how to perform the duties of Islam correctly; illegitimate celebrations and observances; and the worldly punishments for sin and rewards for right conduct. It was a distinctly modern text, reflecting changes in the lives of upper class women at the time (Metcalf, 1990:316). There was advice, for example, on using the post office, maintaining a household while one's husband is away on a government posting, and recipes for European-style bread and biscuits. Thanawi also described acceptable means of income-earning for widowed or unmarried women. 
Thanawi chose to direct his guidebook toward upper class women, rather than men, showing the particular emphasis placed by reformers on the individual behaviour of women and their concern with the affairs of family and household. As well, women were seen to be in greater need of moral instruction. While women and men were both required to exercise moral discipline, it was assumed that women began from a point of less selfcontrol:

...the Bihishti Zewar clearly represents women as always on the verge of moving out of control, of displaying excess, of spilling over-in where they go, what they buy, how much they talk, what they eat. Thanawi implies that most women must struggle more than men to attain the discipline and self-control that are the heart of his teachings (Metcalf, 1990:14).

The reformist emphasis on punishment and reward, and heaven and hell, are dominant themes evident in the hadith that Thanawi emphasizes in Bihishti Zewar: "The one hundred one hadis presented in the book, selected by Thanawi from the thousands available, are chosen to illustrate the promise of reward and the threat of punishment. At least half specifically mention heaven and hell" (Metcalf, 1990:29). Many such guidebooks for women were published at this time. Minault suggests that their similarity to Victorian domestic guides for women reflects not an imitation of their European counterparts but "parallel processes of embourgeoisement" and the need to produce educated wives (1998:101). Bihishti Zewar and many of the didactic novels for women became textbooks in the new schools, both government and private, that were established at this time.

Barbara Metcalf argues that the tradition of the nineteenth century Deoband and revivalist ulama saw no spiritual or moral difference between women and men. They were held to the same standards and were to observe the same moral rectitude. Despite 
the disinterest of Sayyid Ahmad Khan, reformers increasingly articulated the view that women and men were equal in morality, including Nadhir Ahmad (1830-1912) who wrote novels that were included in school curricula, and Sayyid Mumtaz Ali (1860-1935) whose tract entitled "Women's Rights" was one of the more radical reformist statements of the time. The latter advocated education for women and the publication of materials to provide instruction to women and girls, arguing that "isolation and ignorance" of women was not advocated by Islam and would not result in healthy families and a healthy Muslim community. In other words, changes to purdah, education for women, and rights for women in the family were conceived as central to the "health" of the Muslim community. Mumtaz Ali's use of the term "women's rights" foretold the main discursive construct that was used in the twentieth century to secure women's place as equal citizens in the newly conceived Muslim nation. Mumtaz Ali's work did not become a school text or rival Bihishti Zewar in impact or influence. However, he and his wife, Muhammadi Begam, also began a weekly newspaper entitled Tahzib un-Niswan (The Women's Reformer). Like his treatise on women's rights, the newspaper also was attacked by those who thought it went too far in drawing women into masculine spaces and activities and encountered difficulty building a readership, but over time more women began contributing material and it remained in publication for over half a century.

\section{Purdah}

In nineteenth century India, the practice of purdah, or the veiling and seclusion of women, was not a specifically Muslim practice so much as a practice among "respectable," upper class Muslim and Hindu communities (although it may have been 
seen as of "Muslim origin"). ${ }^{5}$ It pertained to a small segment of women whose families possessed the economic means - and who were reliant on the services of non-purdah observing women - to maintain it as a practice (Jahan, 1988). For purdah-observing women, life centred around the zenana ${ }^{6}$ or the women's quarters/women's space, physically separated from the mardana or men's space. Though purdah was strongly associated with respectability, it structured women's lives as well as men's in certain ways that reformers began to see as problematic. Purdah was a barrier to women's education and to companionate marriage with its separate men's and women's spaces. Furthermore, zenana life was based on forms of knowledge that were unscientific, and was characterized by syncretic and unreformed religious practices. It symbolized a realm of sensuality rather than morality. Zenana life also entailed the mixing of upper class/caste women with lower class/caste men and women in ways that ran counter to the process of class distinction reformers were trying to promote.

In India there were no strong calls for women to abandon the practice of wearing veils as there were elsewhere in the nineteenth and twentieth centuries, and purdah was rarely overtly criticized until the second decade of the twentieth century (Saiyid, 1998:76). A problem for reformers in creating the modern woman was that practices such as purdah were strongly associated with respectability, part of sharif class formation.

Thus, rather than calling for purdah to be abolished, new types of clothing and modes of transportation were developed to allow purdah observance in girls' schools. For example, headscarves were devised to provide "a new form of modest attire, suitable for the

\footnotetext{
${ }^{5}$ For a description of high caste Hindu didactic writings calling for the reform of purdah in the late nineteenth and early twentieth centuries, see Malhotra (2002). ${ }^{6}$ Or "andarmahal" (inner quarters) in Bengali.
} 
modernizing women now entering new spaces where neither the burqah, designed as outdoor wear, nor the clothes worn inside the home were suitable" (Forbes, 2008:71). Even purdah's most well known critic continued to observe purdah in her school. In 1905, Rokeya Hossain, a writer and founder of a girls' school, published Sultana's Dream, a short story depicting a society in which men were secluded and women were not, and in 1929, she wrote The Secluded Ones, using the didactic style to depict the negative, often tragic, or simply absurd, consequences of purdah observance (Jahan, 1988). Despite this, purdah restrictions were observed in her school, which taught the same curriculum as the other girls' schools focusing on literacy and housekeeping (Forbes, 2008:71).

I suggest that rather than viewing reform of purdah as a matter of women "coming out" of seclusion and into public life, it is perhaps more accurate to see reform of purdah as involving changes in the gendering of space, forms of family life, and sartorial practices; changes that were intended to build a Muslim community by assigning morality to women and furthering the model of companionate marriage and modern domesticity. In part, this different perspective on purdah reform is related to the largely unacknowledged role that women were already playing in "public" life, whether in wage labour, commerce or political involvement. In nineteenth century India, women were cultivators, artisans, industrial workers, ${ }^{7}$ labourers, and peddlers and sellers of various goods and services (Banerjee, N., 1989; Sen, 2004). Many women worked as itinerant

\footnotetext{
${ }^{7}$ Women's employment in factories, mines and plantations did increase over time as small scale village economies were destroyed (Forbes, 1996:157-159, 167). Accurate employment records for the nineteenth century are not always available, but records for the 1920s show that thousands of women worked in mines, and women had been employed in jute and textile mills from the $1850 \mathrm{~s}$.
} 
performers, and women in Bengal and elsewhere had their own "street culture" of festivals and ceremonies (Banerjee, S., 1989a:129). Malhotra provides an example of the political role that women played in kinship groups, managing relations among families through rituals such as gift exchange and ceremonies where prestige was displayed, reputations of families established, and marriages planned (2002:197). A series of four Muslim women ruled the state of Bhopal from 1819 until 1926 (Khan, 2000). There were women landlords and women moneylenders (Kumar, 1989). Some women were patrons, including patrons of Muslim religious institutions and personages (Kozlowski, 2008:330). Across northern India, courtesans - Muslim and Hindu - were business owners, patrons, and the locus of high culture (music, dance, poetry, etiquette and style). In the city of Lucknow, for example, courtesans were in the highest tax bracket, and were powerful members of the royal court of Awadh until the kingdom was annexed to the Raj in 1856 (Oldenburg, 1990).

This is not to say that women lived their lives alongside men. There was a substantial degree of gender segregation, particularly in northern India. The zenana was associated with a largely homosocial world of women. In Bengal, relations among women of different classes were so close that they shared a distinct dialect that was not spoken by men (Banerjee, 1989b:130). Devji (2008:386), Lelyveld (1996:36) and Minault (1994) also remark on this women's dialect or "begamati zaban" in other north Indian contexts, and on efforts by reformers such as Hali and Thanawi to discourage its use. Banerjee emphasizes the particular role that female education came to play in distancing upper caste/class women from the language and culture they had shared with lower caste/class women, and in giving rise to a distinct middle class culture. Women in 
the zenana also had their own religious practice, ceremonies and rituals, many of which were an anathema to reformed religion, not being located clearly in scriptural religion, or even in the religious traditions of their male kin (Lelyveld, 1996:36; Malhotra, 2002).

In addition to allowing the inappropriate mixing of women from different classes, the physical separation of women's and men's worlds was also a barrier to companionate marriage. Women observing purdah would often remain unveiled in front of men to whom they did not need to display respect, such as labourers, servants or shopkeepers. At times, male reformers complained that women were only secluding themselves from their own male kin (Malhotra, 2002:128). ${ }^{8}$ According to reformers, women needed to take greater interest in their husbands, and do more to render themselves attractive to them, in order to keep men from dissolute lives in the company of courtesans (Malhotra, 2002:124; Minault, 1998:48). The zenana was also not geared to modern child rearing. Zenana mothers were seen as lenient, neglectful, uneducated, and unhealthy (Lelyveld, 1996:49; Malhotra, 2002:126-27). The separation of male and female worlds meant that children were often raised by a variety of relatives. Boys were with mothers and female kin for the first few years of their lives, after which they entered the male world. Lelyveld remarks that among the first generation of Aligarh students, and the generation of their parents, "One is hard pressed to find cases of children raised simply by father and mother" (1996:42). The educated housewife, skilled in the administration of the home, would also reduce the dependence of sharif women on menials and servants who could potentially take advantage of the unworldly and uneducated zenana woman.

\footnotetext{
${ }^{8}$ See also comments by Minault with reference to Muslim women in twentieth century colonial India who would not veil among strangers, but among those who mattered in judging the family's reputation (1998:280).
} 
According to Judith Walsh (2004), the denigration of women that was so pervasive in domestic manuals, and seemingly at odds with the simultaneous portrayal of women as the moral centre of their communities, was intended to diminish the authority of older women in the extended family - grandmothers, aunts, and other relatives and neighbours who represent the women's culture of the zenana. It was this older generation of women, who were able to influence young women and to teach them the ceremonies and customs, modes of speaking and acting, and general cultural life of the zenana, that reformers sought to critique in their descriptions of quarreling, gossiping, ill-informed and poorly-behaving women. Domestic manuals and didactic novels were meant to distance younger women from female elders, while schooling would teach standardized dialects, religion as code of conduct, and scientific knowledge rather than the customs and knowledge forms of the zenana, such as herbalism, amulets, and traditional midwifery (Metcalf, 1990:10). The housewife represented in domestic manuals and didactic novels was still centred within the home, but her thoughts were oriented to the public. Unlike the unreformed women of the zenana, if she did converse with other women, it was regarding "useful" topics such as "health and proper child-rearing, or how to bring literacy to the servants" (Minault, 1998:46).

Devji (2008:381-82) points out that in the traditional legal discourse of Islam, it was not women's sexuality or sensuality that needed to be guarded against through their physical separation from men, but rather it was love or undue attachment that was a potential source of chaos and loss of control. In contrast, as they drew men and women into the same moral community, Muslim reformers began to valorize love, to redefine women as asexual mother figures and chaste housewives, and to view sensuality as a 
threat. Reformers also began to advise women in their writings on new styles of dress that would conceal their bodies better than the garments previously worn by north Indian women (Amin, 1996:126-27; Malhotra, 2002:128-130). The British had already recorded their objections to the revealing clothing practices of upper class north Indian women (Cohn, 1996:136-143), as well as deeming the zenana to be a realm of idleness and sensuality - both cardinal offenses against Victorian values. Viewing the zenana as a realm of sensuality was not new. However, viewing women's sensuality in and of itself as a threat to the honour of men was.

As women were made into moral and ethical subjects through a combination of religious instruction and training in modern domesticity, their presence in public was increasingly linked to prostitution. In the latter part of the nineteenth century, Indian women were accused of being prostitutes at almost every turn. This was in part because of alarm over venereal disease among British troops. In the nineteenth century, British concerns over venereal disease, said to be infecting one in four soldiers in India, considerably shaped bifurcated ideas of moral and immoral women and the meaning of Indian women's public presence. In 1864, the British government enacted legislation to register and medically inspect prostitutes both in India and Britain. Other measures of regulation and surveillance were also taken such as quarantining those infected in special hospitals, and retaining select prostitutes in quarters near cantonment areas to serve only British troops (Ballhatchet, 1980; Levine, 1994, Oldenburg, 1984:131-142; Metcalf, 1995:102-104). Concerns about venereal disease were so strong that all Indian women came to be seen as potential prostitutes and carriers of disease, leading to an outright ban on almost all Indian women working or living in cantonment areas. Metcalf writes: 
While 'respectable' British women might openly traverse the city streets, if only in certain times and places, no such secure public arena existed for her Indian counterpart. Almost any Indian woman outside the seclusion of the zenana could thus potentially be suspect as a prostitute, and a bearer of disease (1995:103-4).

The charge of prostitution was leveled more generally at women whose lives did not conform to the emerging norms of middle class domesticity. This included women who migrated to the cities of Calcutta and Bombay to work in jute and textile mills; a 1924 government report declared that they were "mostly degraded women and prostitutes" (Sen, 2004:84). Hindu devadasis were referred to as "temple prostitutes," while zenana women were seen as akin to prostitutes by the British (Metcalf, 1995:102, 107-8). Courtesans, who were part of the cultural and political life of north India, found it increasingly difficult to continue their way of life as the royal courts disappeared and the emerging political order saw the culture they were associated with - "singing and dancing" - as immoral and in need of regulation and control (Kumar, 1993:35-36; Oldenburg, 1990). The more radical reformers offering “women's rights" perspectives, such as Mumtaz Ali and Muhammadi Begum, were also accused of promoting prostitution (Minault, 2008:368).

The most influential defender of purdah was Abul A'La Maududi (Maulana Maududi), the founder of the Islamist party, Jamaat-i-Islami. In 1939, he published a short book entitled, Purdah and the Status of Women in Islam, in which he argued that there were biological differences between the sexes that required women to remain veiled and secluded. This was a central tenet of Islamist ideology, and a break with the previous discursive tradition of legal or scholarly Islam which did not make this biological argument. I discuss Maududi's arguments further below, but when purdah came to be defended in the twentieth century, it was not a call for a return to the zenana of a century 
before. It was not a call for women to return to their private pagan past, nor a call to resurrect the cultural life of the purdah nashin. ${ }^{9}$ The zenana that Maududi envisaged - or harem as he called it - was one whose inhabitants had been Islamized through the social and religious reform movements of the nineteenth century. It was the modern home and family based on companionate marriage, new forms of modest dress, the modern roles of housewife and husband as household head, and a reformed Islam emphasizing individual pious practice.

\section{Shariat}

Shariat refers to the entirety of the teachings on how Muslims are to practice their faith, contained in the texts of Islam as well as the commentaries on them by scholars of the Islamic tradition. This is a huge body of text, with different schools of interpretation (fiqh). However, in colonial India, laws were passed formalizing and limiting the authority of shariat to matters pertaining specifically to marriage, divorce and inheritance. This was similar to developments taking place in many Arabic-speaking countries during the nineteenth century whereby reformed shariat was brought to bear on only one form of law: "Criminal, civil and commercial cases were decided according to European codes and procedures, and the authority of the shari ' $a$ and of the judges who dispensed it, was confined to matters of personal status" (Hourani, 1991:345-46).

On the face of it, the reinterpretation of shariat as family law might appear to support the type of argument put forth by Partha Chatterjee - that the public is reformed, while tradition, symbolized here by shariat, is preserved in the private/family domain. ${ }^{10}$

\footnotetext{
${ }^{9}$ Women who observe purdah.

${ }^{10}$ Though Chatterjee's argument refers to the Hindu respectable classes of Bengal.
} 
In fact, shariat interpreted as a set of rights (to initiate divorce, to be protected from unilateral divorce, to child custody, to receive maintenance or alimony, and to inherit property), and enforced by state law, was a means both of countering local structures of political authority, as well as the authority of the ulama, giving further shape to the companionate family, defining a Muslim collective and administering the lives of its individual members. The issue then is not so much that shariat is limited to family law, but that shariat becomes family law, reflecting the central role of the family in modern political forms, "For the family is not merely a conservative political symbol or a site of gender control. By virtue of being a legal category it is an object of administrative intervention, a part of the management of the modern nation-state" (Asad, 2003:230).

According to shariat law as codified in British India, women were entitled to inherit an amount equal to half that of their male kin, but its application was not consistent. In some cases shariat was strictly enforced even if Muslims did not follow its injunctions and in other cases exemptions were given on the basis of "custom," particularly in areas where British administration was predicated on land ownership and systems of patronage (Kozlowski, 2008:334-35). This was the case in Awadh after it was brought under colonial administration in the mid-nineteenth century, where a landed class was created through the awarding of estates to politically powerful taluqdars, ${ }^{11}$ and women's rights to inherit based on shariat were disallowed in favour of male primogeniture in order to maintain the estates and the power of the taluqdars (Metcalf, 1979). In a similar manner, British officials sought to codify "customary law" in Punjab

${ }^{11}$ An assortment of "Clan chiefs, military adventurers and the former ruler's courtiers" (Kozlowski, 2008:335). 
in order to support what they saw as the "tribal" political structure of Punjab" (Gilmartin, 1981:160). Under the resulting laws, women were not allowed to inherit in favour of agnatic succession to ensure that land titles would not go to those outside the village when daughters married. ${ }^{13}$

The right of women to inherit thus became an issue at the heart of competing political understandings of Muslim society in India. Customary law was based on a notion of Muslims as "tribal" and was part of a legal system that supported colonial rule. Shariat law, with its guarantees of women's rights to inherit, was based on a notion of Muslim solidarity over and above kinship and tribal political authority, and was opposed to colonial rule. Liberal Muslims, more commonly referred to as "Islamic modernists," emerged as champions of shariat law. During the first decades of the twentieth century, Muslim men and women advocated women's inheritance rights in print, and during the 1920s, after the advent of elected provincial assemblies, some Muslim nationalist politicians argued in favour of women's inheritance. However, the landlord-dominated, loyalist Unionist Party controlled provincial assemblies in Punjab and Sindh and prevented any moves toward shariat law. During the 1930s, the issue was discussed in the Central Legislative Assembly. Muslim League leader, Mohammad Ali Jinnah, was in favour of women's inheritance, but he too had to consider the power of the rural elite.

\footnotetext{
12 The vague and varied kinship formations of the Punjab were combined under a concept of "tribe" for purposes of administration under British crown rule, though in present-day Pakistan, the term is used for Pashtun and Baluch kinship groups that have a distinct political leadership that carries out judicial functions, liaises with external political entities on behalf of the group and at times organizes military and policing activities. ${ }^{13}$ Some British officials opposed the codification of customary law, worrying that the courts would lag behind the growing individualism of Punjabi society. As well, some landed families in Punjab complained that the application of the law was disinheriting their daughters in favour of distant male kin (Gilmartin, 1981).
} 
Nevertheless, two shariat-based laws were passed at this time. The Shariat Application Act of 1937 allowed women to inherit some property, though not land. The interpretation of shariat according to Hanafi fiqh, dominant among the ulama in north India, allowed little scope for women to seek divorce. With many women renouncing Islam in order to divorce, the Dissolution of Marriages Act (1939) was passed based on Maliki fiqh, which does allow women to initiate divorce. It was not until after independence that the coalition of nationalists and middle class women succeeded in obtaining the law they wanted: the 1948 West Punjab Muslim Personal Law (Shariat) Application Act specified that shariat would be the basis for deciding succession, including succession of agricultural land. Women's inheritance rights figured prominently in the Muslim League project of advancing a "nation" of Muslims and weakening tribal authority.

Like reformers of the liberal or Aligarh persuasion, the ulama advocated women's rights in Islam, but they opposed the British courts (Kozlowski, 2008:334). Shariat as codified law, and its application by British or British-trained judges in the Indian courts, challenged the authority of the ulama while usurping their role as interpreters of shariat and changing the very meaning of shariat. The conflict between liberal Muslims and the ulama was not one of shariat law versus some other type of law. Rather it was one of whether shariat law would continue to be administered by secular courts, as it was under the colonial state, and refer only to family law, or whether shariat in its entirety would fall under the purview of shariat courts overseen by the ulama.

Nevertheless, Muslim politicians of various persuasions did achieve a fair degree of consensus around efforts to enact shariat as personal law. According to Minault,

[Jinnah's] most successful efforts at coalition-building among Muslims prior to the Pakistan movement were focused on those legal issues that linked women and 
family life to Islamic legal identity, and that further linked the concerns of Muslim urban and small-town professionals and "ulama at the expense of rural landed interests" (1998:306).

The Shariat Application Act of 1937 passed in the Central Legislative Assembly with Muslim politicians of many stripes, including Muslim League and Congress Muslims, ulama and secularists, arguing for the law on the basis of women's betterment and women's rights (Minault, 1998:301-302; Saiyid, 1998:14-15). Though the law itself had little effect on women as a group, enacting shariat was a symbol of women's rights, a challenge to the authority of kinship, tribe and colonizer, a model for centralized government with legal authority over the family, and an underpinning for a horizontal Muslim moral collective. On these issues there was potential to build Muslim unity as long as the laws did not go "too far."

\section{The Moral Woman and Nationalist Politics in Twentieth Century Colonial India}

In the late nineteenth century, Indian demands increased for political representation in the colonial state. The Indian National Congress was formed in 1885 among educated urban Indians initially to advocate for representative institutions and fairer treatment for Indians employed in the Indian Civil Service. The strain of Muslim reform that in the nineteenth century began with efforts by Sayyid Ahmad Khan and the followers of the Aligarh college and others to educate the male Muslim elite for positions in the colonial state gave rise to a focus on legislative representation for Muslims in the twentieth century. The All-India Muslim League was established in 1906. Mohammad Ali Jinnah, a lawyer and activist in the Congress Party joined the Muslim League in 1913, and eventually became its leader. The impetus behind Muslim nationalism, it is generally observed, came from particular groups of Muslims - Alavi (1986) points to the 
Muslim "salariat" - who were concerned that they would be at a disadvantage as a socioeconomic grouping relative to Hindus in an independent India.

While it is common to see the Muslim League as "communal" or "separatist," almost all political organizing in India was denominational. While the Indian National Congress encompassed Muslims as well as Hindus, Muslims were represented within the Congress by Muslim leaders (Ahmad, 2000:11). Muslim leaders within the Congress, like those in the League, also claimed to represent all Muslims, though on the basis of a different type of politics. Apart from a small group of leftists drawn to the leadership of Jawaharlal Nehru, Muslims within the Congress tended to be more religious, including members of the Deoband ulama. The Congress provided a context to participate in anticolonial politics that would allow a role for the ulama as leaders of Muslims both during the anti-colonial struggle and in a future Indian state.

The Muslim League was composed largely of urban professionals, among them a particularly large number of lawyers. The League's approach was exemplified by the Muslim nationalist poet and philosopher, Muhammad Iqbal ${ }^{14}$ (1877-1938), whose interpretation of Islam contained strong support for secular, liberal, national and parliamentary principles. Iqbal emphasized the need for individual autonomy, reasoning and selfhood (khudi); called for an "ethical community," sovereignty of the people over religious figureheads, and the institutionalization of the Islamic principle of ijma (consensus) (Masud, 2009:247-251). Opposing "tribal" authority, Iqbal wrote that Islam "recognizes the worth of the individual...and rejects blood-relationship as a basis of human unity" (Gilmartin, 1981:161). In 1930, Iqbal expressed the desire to see a

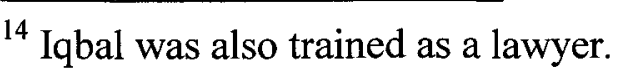


territorial Muslim homeland in India's northwest, though the Muslim League did not articulate a demand for "Pakistan" until 1940.

As nationalism spread during the twentieth century, Muslim women were involved in two main types of nationalist politics, one that was focused on law, political representation and the social; and a second that was associated both with the Gandhian movements of the 1920s and 30s, as well as with anti-British agitation among ulama and religious Muslims, in which religious symbols and piety figured prominently in anticolonial mass protest. These forms of political activism were not mutually exclusive; some women were involved in both, just as the Indian National Congress embodied both types of politics, though their political objectives and modes of operating were distinct in some crucial ways. The first type of political activism, which I will refer to as social feminism, was predominantly secular in its mode of argument, though religion was often referred to as a basis for ethical conduct. It asserted women's inherent right to represent social issues, and was closely aligned with political centralization by promoting ideas of universal citizenship and lobbying politicians for legislation governing relations within the family. The second mode of politics, associated with Gandhi's philosophy and practice of satyagraha (truth force), and which I refer to as piety politics, was suffused with religious symbolism and focused on educating the conduct of participants along lines that emphasized self-sufficiency, sacrifice and pious self-formation. Its politics focused on promoting religious observance, shaping individual moral conduct through embodied practices, and performing personal acts of protest such as spinning and weaving, and wearing only homespun garments. Below I describe each variant and its place in India's political formation as nationalism spread during the first half of the 
twentieth century, with a focus on Muslim women's participation, although Muslim women and Hindu women were often involved in the same organizations, rather than distinct ones. ${ }^{15}$ In each case, male politicians were surprised at the strength of women's activism (Forbes, 1979:11; Sinha, 2000:631).

\section{Social feminism}

Several Muslim women's associations were formed in the early twentieth century. The Anjuman-I-Khavatin-I-Islam (Muslim Ladies' Association), or AKI, was created in 1914 at the inauguration of a girls' school in Aligarh. Their central concerns were to promote women's education through print and publishing and by establishing and securing funding for schools, and to shape the content of curriculum for women's education with a focus on homemaking, health and hygiene, and religious education. Branches were established in cities throughout India. They also took up issues of family reform. The AKI's boldest action was a 1918 resolution against polygamy, which was attacked by the Muslim press who accused the women of copying the west.

The All-India Ladies' Association was formed in 1918 by Sultan Jahan, the ruler of the state of Bhopal, to "promote cheap and accessible classes on hygiene, housekeeping, and religion" as well as to provide "disadvantaged women" with the skills "to protect them from poverty and indigence" (Lambert-Hurley, 2004:48). The latter included basic nursing, midwifery and income-earning skills. Female health practitioners were still few, although women's organizations sought to promote their training, in a context in which male practitioners were not seen as acceptable to care for women in

${ }^{15}$ Research specifically addressing Muslim women's politics in early twentieth century India includes Ali (2000), Amin (1996), Forbes (1996:196-203), Lambert-Hurley (2004), Minault (1981), Saiyid (1998), and Mahua Sarkar (2008). 
purdah, and traditional midwives (dais) were increasingly defined as dirty, evil, and to be avoided at all costs (Amin, 1996:118). Both the AKI and AILA reflect attempts to diffuse homemaking, modern health and hygiene practices, education for girls of middle class families, literacy and vocational training for poorer women, and the advocacy of family law.

The AKI began to wane after a few years, besieged by differences and disagreements among its members and, despite attracting many prominent Indian women to its first meeting, the AILA did not reconvene again. Different perspectives on how to observe purdah protocols at meetings, and whether to call for a loosening of purdah, became a source of disagreement among women from different regional branches of the AKI and within the AILA (Lambert-Hurley, 2004:51; Minault, 1998:296). Also, with the expansion in representative government after the Government of India Act of 1919, and with the growing energy devoted to overt nationalist politics during the 1920 s, neither the AKI, nor the AILA appeared able to accommodate the emergence of varying political perspectives within their ranks the way that new all-India women's organizations could (Lambert-Hurley, 2004:56; Minault, 1998:298).

"All-India" organizations established at this time included the Women's Indian Association founded in 1917 and the All-India Women's Conference established in 1927. These organizations also focused on extending education for girls and women and pursuing domestic reform through legislation to prohibit child marriage, restrict polygamy, and reform inheritance and divorce laws. As described in the previous chapter, they also became involved in discussions surrounding women's franchise and political participation. Muslim women were among the members and leaders of these 
organizations, which prided themselves on representing Muslim and Hindu women together. In fact, there was a great deal of commonality in the objectives of Muslim and Hindu women involved in social feminism. Their emphasis was on social work, medical care for women, and philanthropy and they were able to unite during the 1920 s over the issue of legislating restrictions on child marriage. Debates surrounding separate electorates and the introduction of such electorates for the central Constituent Assembly by the Government of India Act of 1935 created tensions within the all-India women's organizations, as did the tendency for AIWC members to give expression to Hindu nationalist discourse emphasizing a "Golden Age" when women had education and political power before Muslim rule in India (Forbes, 1996:80). Forbes notes that “[AIWC's] leading members belonged to Congress, passed resolutions to support Gandhi's constructive program, and frequently praised Gandhi and Nehru for supporting women's issues" (1996:196), alienating women who may have supported other parties such as the Muslim League or the Communist Party. As a result, some Muslim women formerly active in AIWC joined women's organizations within the Muslim League, but others opposed separate electorates and remained active within AIWC (Forbes, 1996:196-203).

Although they claimed to speak for all women, women's organizations never had a mass base among women, nor did they seek one, always emphasizing the need, discussed in Chapter One, to keep control in the hands of the right kind of women. Some women did benefit from programs and services offered by women's groups to provide skills training or accommodation in hostels for women. Social feminism was in large part responsible for extending girls' education and bringing women and children under the 
ambit of medicine and population health through doctors, nurses, health visitors, modern midwives, maternity centres, and clinics staffed by women (Ali, 2000:90-91; Forbes, 1996:161). However, specific issues of concern to women who worked in factories, mines, agriculture, or domestic service, or women who worked as labourers in cities, were not as evident in their activism. For example, during the Bengal famine of 1943-44, which claimed over three million lives, AIWC was heavily involved in providing services such as relief centres and food kitchens, but it resisted taking part in political action such as marching on rice mills to demand lower prices, and did not encourage mass membership for fear of "communist takeover" (Forbes, 1996:211). Women's organizations attempted to disseminate the model of the middle class home to poorer women and concentrated on teaching women homemaking and vocational skills such as sewing and handicraft production that were premised on the concept of the male breadwinner-housewife dyad.

\section{Piety and mass politics}

A second type of nationalist politics that women became involved in was reflected in the mass agitations against British rule during the Khilafat (1919-1924), NonCooperation (1920-1922) and Civil Disobedience (1930-1932) movements. These movements relied or committees of "volunteers" in localities throughout India who encouraged or enforced strikes and boycotts, propagated the philosophy of the movements, conducted fundraising, and oversaw meetings and local visits of the movement leaders. Tens of thousands of people were involved in volunteer committees throughout India. These movements also mobilized people through oratory and poetry 
readings, communicating a message that was more immediate and comprehensible than that of the constitutional lawyers within the nationalist movement.

The Khilafat movement (1919-1924) drew many Muslims into anti-British agitation over concern for the demise of the Ottoman Caliph, the symbolic seat of the Muslim world community, after World War One. The Khilafat movement was promoted by some Muslim politicians as well as Deobandi and other groups of ulama, and supported and encouraged by Gandhi in particular who formed an alliance with Khilafat movement leaders to join forces with his 1920-22 Non-Cooperation movement. The Muslim League was opposed to the Khilafat movement, with its symbolic defense of the traditional Muslim state, and interpreted Congress support for the movement as an attempt to channel Muslim sentiment away from the League. Though the Ottoman caliph had little bearing on how Muslims lived their lives in India - and in the end it was the Turks that abolished the caliph - the defense of the caliph was symbolic of the defense of Islam against British imperialism and became a basis upon which to pool Hindu and Muslim protest against British rule (Minault, 1982).

The Khilafat movement was one of the first modern political movements in which Indian Muslim women participated in significant numbers. Women's activities in the Khilafat movement melded with the key themes of the Non-Cooperation movement, particularly nonviolent resistance to British rule through tactics such as boycotting foreign goods, and pride in one's own culture expressed through pious religious practice. Activities for women included boycotting foreign goods, economizing in the household, and spending a certain amount of time every day at the spinning wheel. Women who were leaders in the movement tried to inculcate these behaviours in other women, 
collected money and donations of jewelry from women to help fund the campaign, and urged women "to do their duty to God by supporting their men and imbuing their children with religious faith and patriotism" (Minault, 1982:150). Gandhi typically offered women role models derived from Hindu tradition that emphasized chastity, suffering and self-sacrifice (though when speaking to Muslim audiences he compared British rule to the rule of Satan), while emphasizing that spinning was the religious duty of Hindu and Muslim women alike (Forbes, 2005:39). Spinning was not just an assertion of national economic self-sufficiency. Spinning offered a non-denominational embodied practice whose daily performance inculcated self-discipline; India's salvation lay in the individual act of spinning.

From 1930 to 1932, Gandhi launched another mass campaign. The Civil Disobedience campaign relied heavily on women's networks and organizational capacity built during the preceding years for its success (Forbes, 2005:46). The "Salt March" which began the movement was limited to men, but Gandhi specifically chose women to picket cloth shops, liquor stores and salt works, on the premise that it would reduce the likelihood of protests turning violent. Women were again encouraged to spin, and to instruct other women on spinning and on the general philosophy of the movement. Unlike the social work and political lobbying of liberal feminists, women did not meet the same level of opposition within their communities for participation in this type of political protest involving activities that were largely centred in the home. At all-women pickets, women did not engage in direct confrontation but provided a type of moral presence. To play this role, women needed to claim moral authority - to inhabit the role of the pure and suffering goddess Sita. Involvement of women was tightly controlled by local 
organizers; Gandhian movements mobilized women specifically as moral agents who would exemplify, and be able to instruct other women on, the central values of the movement including knowledge of religious tenets, spinning, economizing in the home, and protecting and projecting their sexual purity. While many women wanted to join the protests and boycotts, those who were "undesirable," "low class" or "leftists" were not wanted in the protests (Forbes, 2005:47). Congress discouraged groups of prostitutes who were eager to protest British rule, and women in the movement's leadership complained about their presence. The movement had to be led by women whose class background and behaviour rendered them "respectable," otherwise respectable families would not participate (Forbes, 2005:42). But most importantly, the power of the individual moral example was fundamental to Gandhi's form of protest, satyagraha.

For the ulama involved in the Khilafat movement, the boycott of British goods extended to the boycott of British institutions. Shariat courts and an amir (chief), as opposed to liberal courts and parliaments, were seen by many ulama as an alternative model for a post-independence polity and steps were taken to elect an amir, establish shariat courts, and collect Islamic taxes during the noncooperation movement (Hasan, 1981:908-909; Minault, 1982:153). How such a political model would fit within an independent India was left unspecified, but the ulama did not envision themselves living under a secular state, and this was not the vision of Gandhi either. Leaders of piety movements saw India as composed of religious communities that, within themselves, would be able to identify their own authentic and legitimate leadership. Much to the chagrin of the Muslim League, it appeared that Gandhi saw pious Muslims and the ulama as fitting this leadership role for Muslims. 
While the leadership of both liberal and piety movements came largely from urban educated women, liberal feminism remained limited to a small group of women, often from politically prominent families. A greater diversity of women became involved in the mass mobilizations, boycotts and non- cooperation movements of the 1920s and 30 s, although the leadership and organizers tried to ensure that "respectable women" were positioned to act as role models for other women. The first brand of women's politics was often accused of mimicking the west, whereas the second situated itself specifically and heavily within claims to represent indigenous culture. In fact, many women were involved in both types of politics, despite the fact that their objectives diverged considerably; the former sought legal reforms and citizenship rights from the colonial state, while the latter was focused on "self-rule," not on accommodation with the colonial state. In the closing years of colonial rule, a new variant of Muslim politics, referred to as Islamism, arose that was antagonistic to women's political activism altogether, one that was led by Muslims who were generally not ulama, but sought nevertheless to bring about an "Islamic state."

\section{The Jamaat-i-Islami and the "Islamic State"}

In his 1939 book entitled Purdah and the Status of Woman in Islam, Maulana Abul A'La Maududi (1903-1979), founder of the Jamaat-i-Islami (Islamic Party), complained about "oriental occidentals" who mimic the west by advocating women's entry into "public" life:

They think that the woman's role in national life consists in doing social work, attending municipal councils, participating in conferences and congresses, and devoting her time and abilities to tackle political, cultural and social problems. She should take part in physical exercises and sports, compete in swimming, jumping and race contests, and set new records in 
long distance flights. In short, she should do anything and everything outside the house, and concern herself less with what is inside the house. (Maududi, 1972:74)

To illustrate where this can lead, Maududi provided an extended discussion of sexuality in the west, emphasizing abortion, fornication, adultery, venereal disease, and prostitution, characterizing the latter as a preferred career choice among western women (Maududi, 1972). The "oriental occidentals" about whom Maududi spoke were those who sought to establish parliamentary government in India. His portrayal of immoral women in the west was a cautionary illustration of gender relations in liberal democracies. It also reversed western portrayals of the hypersexuality of the colonized Other. ${ }^{16}$

Maududi was a journalist from a sharif background who joined the Congress when he was young but left the party in the 1930s and founded the Jamaat-i-Islami in 1941. He became a key thinker in the rise of a new variant of Muslim political philosophy in the twentieth century that sought to establish a modern version of an Islamic state. ${ }^{17}$ I refer to this movement as "Islamism," however it is also frequently called Islamic radicalism, Islamic fundamentalism, or political Islam. The Jamaat-iIslami's members came largely from urban professional or entrepreneurial backgrounds, not unlike the members of nationalist political movements that the party opposed. Most members of the Jamaat-i-Islami did not have formal religious training in madrasahs and represented a different type of Islamic politics than that of the parties of the ulama. While the ulama are not highly organized and have many schools of thought and interpretation, the Jamaat-i-Islami was founded as a tightly-knit, highly centralized organization, with a

\footnotetext{
${ }^{16}$ Such a portrayal of Indian hypersexuality was made by Katherine Mayo, an apologist for the British Empire, in her 1927 condemnatory tract, Mother India.

${ }^{17}$ The Egyptian, Sayyid Qutb, perhaps the foremost Islamist thinker of the twentieth century, formed many of his ideas through reading Maududi (Choueiri, 1997).
} 
uniform interpretation of the teachings of Islam. The traditional role of the ulama as advisors to the state on matters of Islamic jurisprudence was also very different from the role the Jamaat-i-Islami conceived for themselves. The latter promoted Islamic revolution, seeking to overthrow existing governments and place in power an educated and pious elite who would rule as God's vice-regents. The ulama and Islamists both emphasize shariat, but for the former, shariat is a body of (mostly uncodified) text that requires their knowledge and training to interpret. Unlike the ulama, but like Islamic modernists, Islamists believed that educated Muslims were capable of interpreting scripture on their own. When Islamists call for the application of shariat, they tend to mean the enforcement of individual behaviours derived from those aspects of Islamic scripture that they take to be akin to codified rules of conduct; particularly prayer, fasting, zakat, and Islamic penal laws or Hudood. Whereas the ulama may be thought of as scholars of Islam, the Jamaat-i-Islami presented itself as an army of Islam, with a paramilitary style organization emphasizing loyalty to a supreme leader, elite recruitment, and secretive and authoritarian structures of power. The Jamaat-i-Islami borrowed concepts from revolutionary philosophies of the time, including the idea of cells or cadres, a pyramid of authority, and a small organization that would act as a vanguard of change.

While the Islamist approach differs from the liberalism of the Muslim nationalist movement, Maududi was also addressing men of the middle class: "those having both the economic power and the social aspirations to emulate the "westernized and westernizing elite"" (Shaheed and Mumtaz, 1990:12-13). He divided Muslims into three categories: 1) those he deemed to be westernized (his opponents); 2) those who were not quite 
westernized but who were involved in modern society (his potential recruits), and 3) the majority of people who had little contact with western cultural influences, and who were of no interest to him. According to Maududi, the latter were "foolish and thoughtless people who cannot think and form independent opinion. These people do not deserve attention and may, therefore, be ignored" (Maududi, 1972:84).

Like other reformers, Maududi states many times that the social order he is creating is "rational" and "scientific". It depends, as the above quotation indicates, on subjects who can "think and form independent opinion." The need for moral conduct and moral order are central to Maududi's philosophy. However, it is not through the social that this moral order is produced. The need for the social to manage risk and create the nation does not arise since popular sovereignty is not acknowledged, representative politics are not envisioned as the basis for an Islamic polity, and a population-based understanding of nation does not exist. Risk and the threat of chaos for Maududi inhere in the mixing of genders. Maududi portrays the control of sexuality as the foundation of an Islamic social order, including strict gender segregation, and extreme punishments to act as a deterrent against "fornication," which is a crime, whether it occurs by "willingness or force" (Ibid:173). Consensual sexual relations outside marriage are a "state" crime, and rape is not a separate crime, but subsumed within the crime of "fornication" for which the victim is culpable. Women are to leave the home only for "genuine needs," and Maududi details a number of restrictions on women's dress, movement and social interactions. Although he concedes that the veiling of women is not mentioned in the Quran, Maududi asserts that it is "Quranic in spirit" (Ibid:198). These components of Maududi's thinking 
were all incorporated into the official policy of General Zia-ul-Haq during the 1980 s, as I describe in Chapter Six.

The meaning of purdah was changed in Maududi's thought, as it was in that of the nineteenth century reformers. The zenana of traditional aristocratic life must not be left as an entirely separate female world. Women must be reformed (Islamized) through religious instruction to become pious Muslims and ethical beings. Maududi wrote that, "in so far as the acquisition of knowledge and cultural training is concerned, Islam does not allow any distinction between man and woman" (1972:156). Women have rights to education, property, and a say in marriage partners. Women's education and the need to ensure domestic harmony remain important. A woman must become a good wife, mother and housekeeper, but must also be trained to "become a good human being, morally as well as culturally" (Maududi, 1972; 156). The similarities here with the earlier discourse of reformist ulama and modernist social reformers are evident. However, unlike reformers before him, Maududi relied on theories derived from medicine, biology and psychology to argue a fundamental difference between women and men: "We now find women as essentially different in kind: They are opposite to men" (Metcalf, 1994:16). Maududi saw sexuality as a weakness in humans that needed to be contained to ensure a moral order (McDonough, 1984:75). This was not unusual in the politics of the time. Gandhi held a similar attitude, although while Maududi emphasized gender segregation and women's seclusion, Gandhi emphasized the practice of celibacy. For both Gandhi and Maududi, women were to practice sexual restraint in order to protect the strength that resides in male bodies. Gyan Prakash writes: "The feminine virtues of chastity and purity were to be used in controlling the virile male bodies, in conserving 
semen and transforming it into a source of power and energy, and in achieving the selfcontrol that Gandhi associated with freedom" (2000:214). Maududi also feared that the exercise of men's sexual energies - assumed to be inevitable if women displayed and moved their bodies in the presence of men - would weaken men.

Markus Daechsel's (2006) research indicates the presence of a wider corporeal politics among the Urdu middle classes during the 1930 s - not unlike middle classes elsewhere at the time - based on the refusal to indulge the body's appetites and desires (for food or sex), or aversions (to exertion or negative sensations). Gandhi too argued that young men must have "bodies of steel" (Alter, 1996:312), a physical hardening to be achieved by exercising restraint with regard to food and sex. Prakash locates Gandhi's corporeal politics in the encounter with colonial governmentality, which seized the colonized body through medicine and public health and which denigrated Indian therapeutics and the Indian body as pathological and unhealthy. The nationalist fought colonialism through "a strategy of self-subjection that colonial governmentality could never deploy effectively" (Prakash, 2000:194). Daechsel stresses a dimension of middle class distinction in the restrained middle class body, which was contrasted to the physicality, differently manifested, of both the working class and the feudal body (Daechsel, 2006:93-113). Daechsel argues, however, that this was a middle class at war with itself since many of the threats to this distinct middle class corporeality were products of middle class culture, such as cafes, cinemas, and various forms of entertainment; free time; and the explosion of print culture. To this list, one might add the threat posed by middle class women engaged in activities such as sports, philanthropy and politics. This middle class culture was shaped by the encounter with colonialism in 
Daechsel's analysis as well: a political and economic system characterized by patronage and colonial tribute made a mockery of the liberal ideal of individual autonomy and channeled the struggle for freedom toward what he refers to as a consumption-based politics of "self-expression." Piety politics placed a strong emphasis on individualized practices of the self as constituting, in and of themselves, forms of resistance to colonialism; as constitutive of a moral self; as indicative of physical health (seen as a necessary component of morality); and as solutions to societal problems. ${ }^{18}$

The Jamaat-i-Islami has always adapted to political circumstances. Though he opposed the creation of Pakistan, Maududi migrated to Pakistan after independence to lead the Pakistan branch of the Jamaat-i-Islami. In practice, by demanding implementation of shariat by the state, the Jamaat-i-Islami over time came close to supporting the notion of the nation-state (Masud, 2009:252). After independence, the Jamaat-i-Islami contested elections in Pakistan, and even endorsed the candidacy of Mohammad Ali Jinnah's sister, Fatima Jinnah, as head of state in 1965, arguing that the pragmatic need to defeat, Ayub Khan, the secular military ruler, warranted supporting a woman as head of state. The Jamaat-i-Islami was part of a mainstream cultural politics that commonly labeled women as westernized or culturally inauthentic if they became too involved in demanding legal rights. Yet, over time, women would become involved in the party, using a language of "rights" and at times engaging in street protests and organizational politics like the liberal women's groups, or "oriental occidentals," Maududi critiqued.

\footnotetext{
${ }^{18}$ For example, Gandhi argued that the solution to famine was greater morality and the practice of celibacy (Alter, 1996:318).
} 


\section{The Demand for Pakistan}

From the beginning, the Muslim nationalist movement encountered difficulties creating a single constituency of Muslims in India. Muslim nationalism was not as strong in Muslim-majority provinces as it was in Muslim minority areas of India and Muslim politics were characterized by diversity rather than unity. Alavi (1986:28), for example, identifies eight different ideological-political positions held among Muslims in India before independence. ${ }^{19}$ In some ways, the Muslim League's trajectory resembled that of the Muslim women's organization, the AKI. The League was also a small organization for most of its history with considerable infighting. It too floundered somewhat in the context of the mass politics of the 1920s when the Khilafat movement met much more success mobilizing Muslims against British rule. The political platform of the Muslim League had much in common with that of Congress, but in its efforts to pursue a joint nationalist cause with Congress it often felt marginalized, much as Muslim women in the all-India women's groups felt "treated, according to their accounts, like younger sisters" (Forbes, 1996:196). Still, urban, educated Muslims and Hindus had more to unite them than to divide them politically. The complex reasons that this joint Congress-Muslim League front did not materialize in the last decade of colonial rule are dealt with elsewhere. Hasan (1993), for example, describes political developments during the period between 1937 when elections were held subsequent to the Government of India Act of 1935, and 1940 when Jinnah first articulated the demand for Pakistan, as a decisive turning point. The influential research of Ayesha Jalal (1985) suggesting that Jinnah

\footnotetext{
${ }^{19}$ For more detailed studies of various movements among Muslims in British India see Hardy (1972), Jones (1989), Lelyveld (1996), Metcalf (1982), Minault (1982), Nasr (1994), and Sanyal (1996).
} 
formulated the Pakistan demand as a bargaining ploy is widely accepted (Ahmad, 2000:6; Hasan, 1993:27; Roy, 1993). According to Jalal, Jinnah's concept of Pakistan was not a territorial entity, but a form of "shared sovereignty" with Hindus. Jinnah referred to Muslim nationalism as "Pakistan Ideology" or "Two Nation Theory," situating Pakistan in the nebulous realm of "theory" or "ideology" rather than territoriality. In fact, those who supported "Pakistan" most strongly lived in parts of India where Muslims were a minority and that would not become part of a territorial Muslim state.

But at the time that the Muslim League began to talk about Pakistan, Congress was focused on achieving self-government and independence as soon as possible. When India was taken into World War Two, Congress launched a "Quit India" movement and the party's leadership subsequently spent much of the war years in jail. After the war was over, the new Labour government in Britain announced its intention to leave India. In this context, Jinnah had little opportunity, leverage, or time to pursue his case for shared sovereignty in constitutional talks. But Jinnah and the Muslim League had time to build a movement, pulling out all the stops to forge coalitions with landowners, ulama, Sufi pirs, and local power holders of various stripes, as well as making direct appeals to "the people," sometimes borrowing "communist phraseology" (Gilmartin, 1988:197). Jinnah adopted the language of communalism, which he had never done in the past, to create a sense of threat to Muslims and Islam. But references to Islam were not only "communal." Islam was offered as the basis of a national, moral collective, and a basis upon which to supercede the "mediatory" politics upon which colonialism had rested. Overt Islamization was in evidence once again, though in a compressed and politically charged climate, in calls to create a Muslim subjectivity through education and through the role of 
the mother. For example, the 1944 Punjab Muslim League manifesto called for Muslims to be trained "in the spirit of Islamic brotherhood and in the traditions of their religion so as to recreate a moral basis for their conduct" and women must be included in this training, for "The moral regeneration of our people must start at the cradle with the spiritual influence of the mother" (Gilmartin, 1988:198). Islam as moral conduct was the basis for horizontal solidarity ("Islamic brotherhood") and a national collective.

In the 1946 elections the Muslim League won all Muslim seats in the central legislature, compared to the 105 of 485 Muslim seats it won in the 1937 elections (Ali, 2000:196), and dislodged the hold of the landlord-dominated Unionist Party from the key Muslim majority provinces of Sindh and, to a lesser extent, Punjab. ${ }^{20}$ Promises of a federation with substantial regional autonomy played a role in convincing many to join the Pakistan cause. In the closing years of British rule, after its relatively unsuccessful history trying to unite Muslims, the Muslim League appeared to broker a unity of Muslim opinion that had not existed in the past and would begin to unravel once Pakistan came into being, when temporary and pragmatic alliances began to disintegrate.

Throughout the 1940s, women were increasingly visible in campaigns for the Muslim League and for the creation of Pakistan (Jalal, 1991). Research on the role of women in the creation of Pakistan often emphasizes their direct involvement with the Muslim League and their mobilization as voters in the 1946 elections. However, women's organizational capacity in the anti-colonial protests of the $1920 \mathrm{~s}$ and $30 \mathrm{~s}$ and their work to create the "social" are perhaps more far-reaching aspects of their role in the political formation of Pakistan (as well as India) than their direct involvement in the

\footnotetext{
${ }^{20}$ For detailed discussions of the Unionist Party's decline see Talbot (1988) and Gilmartin (1988).
} 
Muslim League. Through involvement in the press, modern schools and voluntary organizations, a group of urban educated women that was well-versed and articulate in the national project became strong advocates of the state, investing it as the body with juridical power over the family. They would continue to demand changes to family law after the creation of Pakistan, citing their role in nation-building as having earned them a reciprocal granting of "rights" by the state.

\section{Conclusion}

As the ashraf and ulama sought to position themselves within the colonial state of nineteenth century India, reforming women to fit with emerging understandings of Muslim self and Muslim community emerged as a central concern. Women of the upper class were no longer regarded as sources of chaos and corruption, but as morally equivalent to men. Emphasis was placed on educating women to become practicing Muslims, aware of scripture and careful to avoid non-doctrinal religious practice, as well as mothers and housewives in a refashioned home that was to be the basis for the success of Muslims as a group. Reformers advocated education for women to train them in these new roles. Shariat was to play a greater role in shaping family life, and the practice of purdah was reformed, not through the large scale entry of women into previously male spaces, or through campaigns to abandon the practice of veiling, but through a complete change in domestic culture and women's conduct. How women spoke and what they spoke about, how they dressed, with whom they interacted, their religious observances, their forms of knowledge, and the spatial patterning of their lives all were subject to change so that women could become mothers and housewives whose lives would centre 
on husbands and children, and so that women would be involved in the creation of a Muslim collectivity.

This new moral woman, promoted through a process that may be referred to as Islamization - the creation of a Muslim self in the context of constituting a Muslim collectivity - was central to middle class political movements that emerged in the early twentieth century. Modernist reformers who advocated a secular liberal state, ulama who foresaw a composite Indian nation composed of autonomous religious groups led by learned religious men, and Islamists who formulated the concept of an Islamic state, all promoted the moral woman, and all concerned themselves with what took place within the home. Middle class women engaged in two types of politics, one associated with the social and with concepts of universal citizenship and nation; and another focused on themes of self-sufficiency and concerned with shaping women's practice within the home to promote awareness of religion and embodied pious practice. Maududi and his Islamist movement opposed a public, political role for women, but women were not to be left to their own devices in the home. The home was still a reflection of the polity, based on strict gender segregation and surveillance of gendered conduct and interactions. These various forms of Muslim politics would continue to play out in the post-independence context, manifesting often in debates over "family law," as I describe in the next chapter on state formation in the context of the new state of Pakistan. 


\section{Chapter Three \\ Post-Independence Challenges to Muslim Nationalism and Women's Involvement in Nation-Building and State Formation, 1947-1971}

\section{Introduction}

This chapter examines early attempts to centralize political authority and promote the understanding of Pakistan as a nation, from independence in 1947 until the succession of East Pakistan and creation of Bangladesh in 1971. I begin by discussing the partition of India into the two independent states of India and Pakistan. I then discuss attempts to centralize political authority from 1947 until the imposition of martial law in 1958, drawing attention to multiple challenges to political centralization. The subsequent decade, discussed in the final section of this chapter, was characterized by efforts to entrench the central government by means of a "developmentalist" state. While early state executives demonstrated a preference for colonial models of administration, claiming that Pakistan's inhabitants were not "ready" for democracy, during the 1960 s efforts were made to create citizens with "modern" attitudes by extending the reach of bureaucratic authority over the population and by relying on a model of central planning by "experts" in economic development theory. Distributive, ethnic, and linguistic inequalities during this period led to popular uprisings followed by the re-imposition of martial law in 1969 , and elections in 1970 . In this chapter I also trace the beginnings of a military largely created through tutelage, training and subsidies by international interests - a military that would frequently challenge the sovereignty of parliaments, drain huge sums of money from state budgets and introduce a military rationality into the construction of national interest. When this military refused to transfer power to Pakistan's first democratically elected government, dominated by an East Pakistan-based 
party, civil war ensued resulting in the secession of East Pakistan in 1971.

In this context, women's organizations were among the strongest proponents of nation-building in Pakistan. Throughout the period discussed in this chapter, middle class women's organizations directed their social work efforts toward responsibilizing women and making them aware of the nation. For women to become involved in the nation and to become "free" subjects available for liberal governance, women's organizations considered it necessary for women to be literate, to be healthy, to have fewer children, to be trained in "domestic science," to have skills or aptitudes that would enable economic self-sufficiency, to become moral agents in part through religious instruction, and, perhaps above all else, to be situated in stable monogamous marriages. As I will discuss, among their earliest efforts, women's organizations lobbied state leaders to stabilize and regularize marriage, and worked to ensure that single women who were refugees, or affected by the violence of partition, entered into acceptable marriages. The continuing efforts of women's organizations to secure family law legislation were matched by as strenuous efforts to resist state involvement in the conduct of domestic affairs by opponents of secular nationalism. Family law became a major fault line between the political project of the nation state and religious parties that advocated a differently gendered political order.

\section{Partition}

During the final two years of British rule in India, numerous efforts to negotiate a transfer of power that would avert partition failed, with much blame subsequently being assigned to the central actors including the Congress, the Muslim League, and British 
negotiators, particularly Lord Louis Mountbatten, India's final Viceroy. ${ }^{1}$ In June of 1947, it was announced that power would be transferred to two dominions, India and Pakistan. Part of the plan involved the partition of the provinces of Punjab in northwest India and Bengal in northeast India into Muslim-majority and Hindu-majority sections to be assigned to Pakistan and India respectively. This was not the plan for Pakistan that the Muslim League had wanted, and many alternatives were sought by Jinnah and the League to avoid partitioning Punjab and Bengal, including the postponement of independence, or the transfer of power to autonomous provinces. Some Bengali Congress leaders joined with Bengalis in the Muslim League to propose the creation of a united and independent Bengal (Bose, 1991). Nevertheless, a mere two months later, on August 14th, 1947, India was partitioned and independence from British rule was enacted. Princely states were to accede to one of the two new states and force was used to secure accession where leaders proved reluctant, as was the case with Hyderabad in India, and with the princely states in Baluchistan in Pakistan. The Hindu ruler of the Muslim majority state of Kashmir acceded to India in October of 1947, an outcome that Pakistan's military and political establishment, and various Islamic groups, have never accepted.

The Muslim League's demand for Pakistan contained a contradiction - it was to be both a homeland for Muslims, but also a country that would retain Hindu and Sikh minority communities to ensure the fair treatment of the substantial Muslim minority that would inevitably remain in India (Jalal, 1985:241-42). ${ }^{2}$ Despite the fact that it was the

\footnotetext{
${ }^{1}$ For general accounts of the politics immediately surrounding partition, as well as the human toll of partition, see Gilmartin (1998), Jalal (1985), Khan (2007), Pandey (1997, 2001), Talbot and Singh (2009), Zamindar (2007), as well as edited collections by Hasan (1993, 2000).

${ }^{2}$ After partition, Pakistan contained 60 million Muslims, while 35 million remained in India.
} 
Muslim League that had advanced the claim that Hindus and Muslims were two nations, in the end the strongest support for partition came from the Congress, as well as Sikh leaders, the latter at first supporting and later protesting the partition of Punjab (Pandey, 2001:31-35). ${ }^{3}$ The most important consideration for the Congress was to achieve a strong centralized state - not civil war and not a federation with substantial provincial autonomy, subject to manifold demands for self determination, whether from Muslims, Sikhs, Tamils, or the various leaders of princely states (Pandey, 2001:31-32; Roy, 1993:122; Talbot and Singh, 2009:58). To inherit a strong, centralized state it was better to accept one, and only one, partition.

Massive killing and destruction preceded and followed the creation of the independent states of India and Pakistan. Millions of people were forced to migrate in order to flee the violence of partition, often at a moment's notice, without time to gather belongings or locate other family members. Roughly ten million people migrated across the new borders, while several million more were "internally displaced." The violence occurred in many places in India/Pakistan in 1946 and 1947, reaching its largest scale around the time of the enactment of partition in August of 1947. Among the varied local manifestations and complex causes of the violence, a few key features stand out. Hindus, Muslims and Sikhs were all participants in the violence. The local patterning of "victims" and "aggressors" among religious communities was shaped by the new, or newly emerging, territorial boundaries of the Indian and Pakistani states. There is an understanding that the violence was constitutive of the new territorially defined states (Pandey, 2001). Partition in itself was an event that contributed to the formation of Hindu

\footnotetext{
${ }^{3}$ Gandhi remained opposed to partition but at this time his influence in the Congress was waning.
} 
and Muslim subjectivities. For example, among the Meos of Mewat in present day India, a group whose cultural and religious traditions were both Hindu and Muslim, partition was a watershed event in their twentieth century process of Islamization: targeted as Muslims, "the terror of Partition...made the Meos realize they could no longer "ride two horses' (participate in both Hindu and Muslim worlds) but must follow a single path" (Mayaram, 1997:11). While the violence took place throughout north India, the partition of Punjab and Bengal into Muslim and Hindu sections no doubt contributed to the scale of the violence, dividing people who had been joined by administrative and economic relations, history, culture and language, according to a stark equation of religion and territory.

The character of the violence was not one of frenzy or momentary loss of control, so much as planned, almost military-style, execution (Gilmartin, 1998:1086). While spontaneous participation may have fed the violence, the evidence of organization and planning is present in various reports on the riots that reveal, for example, prior efforts to disarm target populations by police, gathering of volunteers for war parties, collecting of funds for weaponry, command hierarchies, and the organized execution of different phases of the operations (e.g., looting before burning) (Talbot and Singh, 2009:84-85). Another characteristic of the violence was the targeting of women to dishonour entire communities (Butalia, 2000a, 2000b; Das, 1995; Didur, 2006; Menon and Bhasin, 1996, 1998, 2000; Said Khan, 1994). Common forms of sexual and gendered violence evident during partition included the rape, abduction, and sexual mutilation of women. Many women were also murdered by male relatives, or encouraged to commit suicide, so that they would not bring dishonour to their families by being victims of sexual violence. In 
some cases, daughters or young women were traded in exchange for the safe passage of other family members (Said Khan, 1994). Jalal writes that "Crimes against women, generally speaking, had not been a key feature of 'communal violence' until the upheavals of 1946-47" (1996:689). The presence of recently demobilized soldiers is cited as a contributing factor in the different nature of the 1946-47 violence (Bose, 1986:223). However, the instigators and organizers included politicians, police, village leaders, members of militant religious organizations, as well as countless "ordinary" people that, as Pandey emphasizes, seemed to understand partition violence as "simple duty, necessity, the call of the times...that is necessary to secure the life of the community or nation" rather than something extraordinary, or even as violence per se (1997:2045).

This is not to say that various forms of gendered violence followed a singular logic. The use of sexual violence intended to dishonour was associated with the creation of the new nations. A first-hand account from a participant in the partition violence, interviewed by Shail Mayaram, suggests another logic: "We took away the women. That was the system. Women do not have any religion" (1997:191). This statement contradicts the nationalist emphasis on women as repositories of tradition and reproducers of the national collective, and suggests, rather, the opportunistic acquisition of women. Once taken, such women often had children with their abductors and became part of their communities.

For proponents of the new nation-states of India and Pakistan, this was not acceptable. The national dishonour of the sexual violence committed against women was to be hidden or reversed somehow and the new governments of India and Pakistan took it upon themselves to organize, oversee and enforce this task. This included official 
attempts to silence writers who, by documenting aspects of the violence of partition, preserved the memory of this dishonour in their writing. ${ }^{4}$ India and Pakistan also jointly launched a "recovery program" to retrieve "abducted women," legally defined as women who were Muslim immediately prior to partition, but were now living with Hindus, or Hindu women now living with Muslims. The women may have been abducted, they may have married partners of their choice, or they may have been taken in by families of the majority community for safe-keeping during the riots. However, these circumstances were defined in all instances as resulting from the dual crime of abduction and forcible religious conversion and the resulting marriages were nullified by state fiat.

Part of the pressure to retrieve the women did in fact come from their family members. However, there was no similar program to recover Hindu women abducted by Hindu men or Muslim women abducted by Muslim men. The legal category of "abducted women" demonstrated the view of women as the property first and foremost of their religious-national community. The crime was not against the women, but against the community. In fact, many women did not wish to be seized, sent to camps and then deported by agents of the recovery programs. Many had children in their new families and many feared returning to their natal families. Police, together with female social workers, implemented the recovery operation, often taking women by force. Some

\footnotetext{
${ }^{4}$ Sadat Hasan Manto, one of the most famous authors of the Progressive Writers' Movement in Urdu literature, was prosecuted for obscenity by the Pakistan government for depicting the violence of partition in his fiction (Jalal, 1991). The Progressive Writers' Movement in Urdu literature following independence included male and female writers of Urdu novels and short stories. Rape and gang rape and the purchase of young girls by men were commonly depicted. Themes of hypocrisy were common, illustrated, for example, through the ability of men to rationalize rape if the woman belonged to the other religious community, or through portrayals of men who were involved in nationalist or anti-colonial politics yet could not abide autonomy or self-determination among the women of their own families (Haroon, 1994).
} 
women tried to escape and many police convoys carrying "recovered" women were pursued by distraught relatives begging that they be returned. One social worker involved in the program acknowledged that many women feared being killed if sent to their "legitimate" families, although she maintained that the government was acting in the best interests of the women (Das, 1995:72). The claims of state agents to be protecting women's honour superseded women's rights to determine their own interests.

Several interesting features of the recovery operation highlight its importance to the new nations of India and Pakistan. The emphasis was especially put upon retrieving women of child-bearing years, thereby further reproducing the national collective, and acting against the pollution of the collective through intermarriage or other more illicit sexual unions. A major objective, apart from recovering women, was removing those women who signified dishonour and shame. In India, "the task of flushing out Muslim women from Hindu or Sikh homes was constructed as a duty by which Hindu men would regain purity" (Das, 1995:79). The behaviour of the men would no longer be dishonourable if the women - the visible reminders of dishonour - were removed. Recovered women were "rehabilitated" or brought back into the moral order by being taken into camps or shelters, after which some would return to their original kin or enter new marriages sanctioned by the state, while others would remain in the camps for the rest of their lives. Continuing for several years after independence, the recovery programs were a remarkable exercise of the new state powers to intervene within family structures to promote national honour and purity. The governments nullified marriages on the basis of religion; they defined children of such marriages as illegitimate, resulting in a new life for many as wards of the state; and in India, the program arranged abortions for some 
women who were "recovered" while pregnant (Menon and Bhasin, 1998:83). The "abducted" women were a threat to the nation even where they were accepted as members of the communities in which they lived. Das (1995) suggests that the recovery program demonstrated that it was not for communities or kinship groups to sanction marriage, determine the legitimacy of sexual unions, or make decisions about the circumstances of their own reproduction. This power was to be assumed by the state in the interests of the national collective. The family was to reflect the nation, and the government would intervene directly with all of its powers to reorder the lives of women who found themselves in the "wrong" families, forged in the polluting circumstances of national shame and dishonour.

\section{Centralizing State Authority, 1947-1958}

\section{Early Challenges}

Government institutions were reconstituted in Pakistan from the truncated remains of the Indian Civil Service and the military inherited from British rule. Much time was spent on the painstaking process of dividing financial resources, government and military assets, water systems and infrastructure between India and Pakistan, as well as on what was bureaucratically referred to as the "exchange of populations." Many Muslim League leaders, originating from areas now within India, had to resettle in either of the two noncontiguous territories of East and West Pakistan while scrambling to house and staff the new government of Pakistan. Karachi in West Pakistan was chosen as the capital, and was the city with the highest concentration of immigrants from India. A Constituent Assembly, elected in 1946 by provincial assemblies, was to continue sitting until a constitution could be drafted under which elections could be held. In the 
meantime, the 1947 Independence of India Act, together with the 1935 Government of India Act, continued to form the constitutional basis of the government of Pakistan. The All-India Muslim League assumed executive control of the new state with Mohammad Ali Jinnah and Liaquat Ali Khan, both migrants to the new state, as Governor-General and Prime Minister respectively.

The problems of creating a central state authority in Pakistan extended beyond the logistics of planning and coordinating the new government apparatus. In addition to low literacy rates, mass communication links were not highly developed across Pakistan. Few villages had electricity, newspaper circulation and radio reception were limited to cities, administrative officers rarely visited villages, and telephone service was sparse, even for offices connected to state functions. For example, in 1963, less than one third of police stations had telephones in West Pakistan (Von Vorys, 1965:167). Those who were in some way party to the creation of Pakistan - participants in, or supporters of, the nationalist movement - were mostly limited to urban professionals in a country whose population and social structures were predominantly rural and agrarian. Jalal observes that "the British transferred power in India to two centralised high commands instead of the provincial and the local bosses whose support they had so long solicited and used to strengthen their raj" (1990:277). In the case of Pakistan, this centralized command needed to constitute a system of administration to cover territories that had neither been strong supporters of Muslim nationalism, nor part of a unified system of administration under the Raj. Princely states had not been incorporated into the provincial administration at all, and in the major agricultural areas of Pakistan, British rule had buttressed the power of hereditary leaders - large landowners and Sufi leaders - in a system of political 
control based on state patronage of powerful local intermediaries (Ansari, 1992;

Gilmartin, 1988).

Pakistan's population was characterized by linguistic diversity and multiple, salient, ethnic identities, despite its apparent religious homogeneity. ${ }^{5}$ West Pakistan composed of the four provinces of Baluchistan, Punjab, North West Frontier Province (NWFP) ${ }^{6}$, and Sindh - and East Pakistan, roughly corresponded to five major ethnic and linguistic groups: Balochis, Punjabis, Pashtuns (also Pakhtuns or Pathans), Sindhis and Bengalis. A sixth major ethno-linguistic group consisted of Urdu-speaking Muslims from north-central India who migrated to Pakistan at partition. They came to be officially identified as "Muhajirs", a term with strong religious connotations. ${ }^{7}$ There was diversity of Muslim religious practice as well (class, regional, rural and urban), and no consensus with regard to the meaning of Muslim national identity.

The Muslim League was weakened after Independence, when a distinction was drawn between the League as a political party, and the government of Pakistan, and when other parties began to contest the Muslim League's right to control national discourse and central political authority. Just prior to independence, the League had managed to form a loose coalition with politically powerful landowners in Punjab and Sindh who were concerned about the strength of the Congress, its model of political centralization, and its platform of land reforms. Prior to this coalition, Punjab and Sindh had been strongholds

\footnotetext{
${ }^{5}$ The first census in 1951 indicated non-Muslims were only $14.1 \%$ of Pakistan's population.

${ }^{6}$ The province was re-named Khyber-Pakhtunkhwa in 2010 in an effort to move away from the name that signifies how colonial state authorities viewed the province, while also avoiding a name that would hint at a Pashtun nation.

${ }^{7}$ Muhajirs were followers of the Prophet Mohammad who migrated with him from Mecca to Medina to escape persecution and establish a following there. The term thus
} 
of the pro-British Unionist Party. Tribal leaders and ulama in the NWFP tended to support the Congress Party and its pan-Indian, anti-colonial struggle, rather than Muslim nationalism. In Baluchistan, which had been composed of four princely states and a section under British administration, leaders opposed integration with Pakistan, just as they had opposed integration into the Raj in the nineteenth century. Baluchistan has continued to resist central state authority, demanding independence or greater autonomy throughout the country's history, at times mounting insurgencies against the government. Like the Pashtuns, though with a sparser population, the Baluch have a tribal political structure, with small pastoral communities dispersed through mountainous terrain, led by male elders or younger male leaders. ${ }^{8}$ In the first year after independence, until his death in October of 1948, Jinnah continued to tour the regions of Pakistan, much as he had before independence, lobbying with local and regional political leaders to bolster support both for the Muslim League and for a central political administration.

In addition to opposition from Baluch leaders, Pakistan's territorial integrity at independence also was under threat from Afghanistan. The Durand Line, which divides Afghanistan from Pakistan, was imposed by the British in 1893 when they appropriated Pashtun territory between the Khyber Pass and the Indus River, previously part of an Afghan empire. Twentieth century Afghan leaders, up to and including the communist government of the 1980s, consistently questioned the legitimacy of this border and whether the British ever had any right to bequeath this Pashtun territory to Pakistan (Harrison, 1981, 1986). As well, Pakistan continued to fight for control of the Muslim-

evokes connotations of the first community of believers in Islam, migrating so that they could live according to their faith.

${ }^{8}$ They are not identical though. Harrison (1986) describes the Pashtun political structure, with its tribal councils or jirgas, as less hierarchical than the Baluch tribes. 
majority province of Kashmir, resulting in another simmering border conflict that flared into war with India in 1948 and, on a larger scale, in 1965.

The central government could not challenge the political and economic power of landlords in West Pakistan and jeopardize their support for the government and the ability of the government to play a role in food production and distribution. For this reason, an agricultural income tax was out of the question. According to Jalal:

Any attempt to [tax agricultural income] would have sparked off an economic as well as a political crisis. The landlords would refuse to cooperate with the state's procurement efforts and, worse still, there might be a mass exodus of prominent rural notables from the Muslim League, the formation of opposition groups and a serious loss of support for the central government (1990:67).

One 1959 government document estimated that one percent of landowners owned thirty percent of land in West Pakistan, and seven percent owned fifty-one percent of the land (Jalal, 1990:67). East Pakistan, in contrast, was much less dominated by landlords. Three quarters of the land in East Pakistan had been owned by Hindus who mostly fled at partition, and the East Bengal Estates Acquisition and Tenancy Act of 1950 put a ceiling of 33 acres per head on land holdings (Jahan, 1972:18-19). However, the central government proceeded to do more to foment a movement for Bengali autonomy than to cultivate a strong constituency in East Pakistan.

Ethnically and linguistically, East Pakistan was much more homogeneous than West Pakistan, and Bengalis made up the majority of the population of Pakistan. ${ }^{9}$ However, West Pakistanis, particularly Punjabis, predominated both in the military and civil service. In the decade after independence, Bengalis were around thirty percent of those in the Civil Service of Pakistan and the federal bureaucracy, five percent of officers

\footnotetext{
${ }^{9}$ According to the 1951 Census, the population of East Pakistan was 41.9 million, while that of West Pakistan was 33.7 million.
} 
in the armed forces, and ten percent of the "entrepreneurial class" (Jahan, 1972:24-25). ${ }^{10}$ Although Bengali was the first language of fifty-six percent of the population of Pakistan, followed by Punjabi at twenty-nine percent, Urdu — the first language of three percent of the population -was declared the official language, contributing to regional resentment toward the central government. Both Jinnah and Liaquat Ali Khan were adamant that Urdu was vital to the integrity of the new nation. At a post-independence speech in Dacca, the capitol of East Pakistan, Jinnah announced:

...ultimately it is for you, the people of this province, to decide what shall be the language of your province. But let me make it very clear to you that the State Language of Pakistan is going to be URDU and no other language. Anyone who tries to mislead you is really the enemy of Pakistan. Without one State Language, no nation can remain tied up solidly together and function (quoted in Callard, 1968:182).

Urdu as well as English - an important idiom of expression for the political elite of the nationalist movement - were promoted as the official languages of Pakistan and the only languages permitted in official communication. Agitation continued in East Pakistan however, and Bengali politicians insisted that they should be permitted to speak Bengali in the Constituent Assembly.

It remains difficult to apply a uniform system of administration throughout the country. Police are often unwilling to take action against local influentials who in some cases maintain private police, jails or militias, and federal law and the state judicial system exist alongside parallel judicial systems, which at independence included systems in operation in princely states, jirgas or judicial councils, and the Frontier Crimes Regulation (Sardar Ali and Arif, 1994). The Frontier Crimes Regulation of 1901 was a

\footnotetext{
${ }^{10}$ Pakistan continued the racialized military recruitment policies of the British that defined Punjabis and Pashtuns as "martial races" and rarely recruited Bengalis.
} 
means for the colonial state to exercise some degree of control in the northern and western frontiers of British India. In exchange for loyalty to the colonial state, influential figures in local areas were granted widespread powers to police and to punish, powers that included:

'Blockade of hostile or unfriendly tribe', confiscation of the property of all or any of the members of such tribe, prohibition to erect new villages or towers on the frontier, removal of entire villages, demolition of buildings used by robbers and collective responsibility of the entire tribe for the act of an individual tribesman (Sardar Ali and Arif, 1994:19).

This law remained in force after independence. Pakistan's political rulers have occasionally seen it advantageous to use the Frontier Crimes Regulation with its heavy penalties and greater police powers. For example, it was extended to all of West Pakistan for a time in 1962. Throughout Pakistan's post-independence history, the central government has had little legal authority in the tribal areas of NWFP (KhyberPakhtunkhwa) and Baluchistan. Tribal leaders have periodically proclaimed that shariat will be the basis of law in their areas of influence. This apparent expression of Islamism should be contextualized in terms of some of the modern connotations of shariat in the subcontinent as representing an alternative model of political authority - one that localizes rather than centralizes power and one that is more consistent with notions of confederacy than with nation.

\section{Continuation of Vice-regal Rule}

Many administrative arrangements of the British state were retained after independence, including the Frontier Crimes Regulation provisions in the northwest, the pattern of district administration in settled agricultural areas, and the supremacy of the civil bureaucracy over politicians, in a vice-regal system of powerful Governors and 
Governors-General. Assemblies and provincial ministries were regularly dismissed by administrators making liberal use of clauses of the Government of India Act to impose governor's rule or direct rule by the central government, and the Public and Representative Offices (Disqualification) Act (PRODA), to remove individual politicians from power who were deemed unfit to rule. This began shortly after independence when Jinnah dismissed the elected assembly in the NWFP, which had a Congress government. In 1953, Governor General Ghulam Mohammad dismissed the Prime Minister, Khwaja Nazimuddin. In 1954 he dismissed the Constituent Assembly and replaced it with a "Cabinet of Talents" composed largely of senior civil servants. Iskander Mirza, a civil servant and cabinet minister who became Governor General in 1955, gave a speech justifying the government's preference for this model of administration:

Some underdeveloped countries have to learn democracy, and until they do so they have to be controlled. With so many illiterate people, politicians could make a mess of things...There was no point having the fine British administrative system with good traditions that Pakistan had inherited unless it was run in the British way. A district officer or magistrate must be given full powers to deal with any situation. Politicians could make policy, but they must not interfere (quoted in Sayeed, 1960:387).

Mirza became the President of Pakistan after the country's first constitution was enacted in 1956 and appointed another civil servant, Chaudhri Mohammad Ali, as Prime Minister. The British model of district administration prevailed during the Mirza period, emphasizing "autocratic rule with a strong touch of paternalism", as well as the power of the central or provincial government, expressed locally in the "person of the district officer" (Braibanti, 1966:156).

Beginning with Jinnah, political leaders relied heavily on the civil administration and police. The central government was greatly concerned with stemming secessionist 
movements, defending the unstable borders of the new country and maintaining law and order. Three months after independence, a force of National Guards was established to maintain law and order in the country and to allow the military to focus on external threats (Jalal, 1990:73). In 1950 an amendment was made to the Pakistan Penal Code allowing up to ten years in prison for anyone who condemned the creation of Pakistan or suggested changes to its territorial sovereignty (Callard, 1968:54).

In East Pakistan, the strong movement for official recognition of the Bengali language was portrayed as a threat to the integrity of Pakistan, as was any political activity in opposition to the central government. Bengalis were frequently discussed as traitors, communists, or "Indian agents" (Von Vorys, 1965:91,105). Not surprisingly, the Muslim League encountered particular problems maintaining support in East Pakistan and lost badly to a coalition of three other parties in provincial elections there in 1954 . This "United Front" government in East Pakistan was subsequently dismissed by the central government, further fuelling the movement for East Bengali autonomy. The Muslim League did not have a strong support base in West Pakistan either, and by 1956, it had lost parliamentary control in all provinces of Pakistan.

\section{Islamists and Ulama}

Opposition to the state-building project of Muslim nationalism came not only from "local influentials," but also from ulama and Islamists. For the leadership of the Muslim League, the tensions inherent in the suggestion that Muslims were a nation came to a head after the creation of Pakistan when the competing understandings of Islam and state that had been evident before independence continued to play out in shaping the country's constitution. Those political leaders who migrated to Pakistan at partition, and 
who then sought to play a role in shaping the constitution of the new state, included not only members of the Muslim League, but also some ulama and Islamists who had opposed the creation of Pakistan. Most notable among the latter was Maududi who migrated to lead the Pakistan branch of the Jamaat-i-Islami. Thus Islamic Modernist understandings of Muslims as a nation with sovereign elected institutions competed with notions that the ulama should oversee law-making, and with notions that Pakistan should be an "Islamic state" focused on implementing Islamic codes of conduct. Maududi was imprisoned in 1948 for threatening the security of the state with his accusations of the government's un-Islamic nature.

In 1953, several Islamic parties precipitated a crisis by demanding that the government ban members of the Ahmedi sect of Islam from government posts and declare them non-Muslims. ${ }^{11}$ When the government refused, the parties organized widespread riots in Punjab, in which several Ahmedis were killed. Martial law was declared in Lahore, the city most affected by the riots, and a government-appointed Court of Inquiry was established to investigate the "disturbances." The Inquiry report attributed blame to two political organizations, the Majlis-i-Ahrar-i-Islam and the Jamaat-i-Islami for initiating the riots, and the Punjab Muslim League for supporting and encouraging the anti-Ahmedi protests. Maududi was originally sentenced to death for his role in the 1953 anti-Ahmedi riots, but eventually served a two-year prison sentence. ${ }^{12}$ As part of its mandate, the Inquiry also sought to resolve the question of "Who is a Muslim?" The

\footnotetext{
${ }^{11}$ Ahmedi refers to a religious sect within South Asian Islam that believes their founder, Mirza Ghulam Ahmad, was a prophet. They are thus considered heretics by some, since orthodox doctrine specifies that Mohammad was the last prophet of God.

${ }^{12}$ The court-ordered release of Maududi is a notable instance of the judiciary overturning decisions of state executives.
} 
judges concluded that no satisfactory answer could be agreed upon by even two religious scholars - an early official statement that Islam was too diverse to codify.

The Jamaat-i-Islami began in Pakistan with a mostly Urdu-speaking, Muhajir membership. The organization had little appeal among poorer Pakistanis who predominantly spoke regional languages, rather than Urdu, and whose practices, such as saint worship, were abhorrent to the Jamaat-i-Islami (Nasr, 1994). At this time, the party did not seek a popular support base, but focused its organization and recruitment efforts on universities campuses. In 1947, a student wing of the Jamaat-i-Islami, the Islami Jamiat-i Tulaba (IJT), was established to attract the appropriate caliber of membership to pursue Maududi's political objective of "revolution from above." The IJT soon became heavily involved in countering leftist student organizations (Nasr, 1992:61-62). This led to an ideological polarization in the academic context between Islam and Marxism. These clashes between Marxism and Islam began to extend beyond campus politics to larger political battles. The increase in open conflict between the Jamaat-i-Islami and the central government resulting from the anti-Ahmedi crisis shaped the organization further along the lines of a militant "soldiers' brigade," willing to engage in street battles against the government and other political groups in the name of Islam (Nasr, 1992:63).

While the Jamaat-i-Islami focused its efforts on street politics, building a revolutionary movement, and mounting an unrelenting critique of the government, the ulama placed their emphasis on achieving constitutional arrangements that would provide a role for them in the jurisprudence of the new state. Several leading ulama released a statement in 1951 outlining their view that Pakistan's state must be based on the sovereignty of Islam, not on such national identifiers as "geography, race or language" 
(Zaman, 2002:93). It took nine years to draft a constitution, in part because of the difficulties inherent in reconciling the perspectives of the ulama with those of Islamic Modernists and secularists who predominated in the leadership of the Muslim League, the military and the bureaucracy. Key demands of the ulama included that the head of state should be a Muslim, and that there should be a committee of ulama to decide whether government legislation contravened the injunctions of Islam. The contrasting view of the government that legislative authority must be located in an elected assembly and not subject to review by ulama was expressed in the Report of the Court of Inquiry into the 1953 Disturbances:
Absolute restriction on the legislative power of a State is a restriction on the sovereignty of the people of that State and if the origin of this restriction lies elsewhere than in the will of the people, then to the extent of that restriction, the sovereignty of the State and its people is necessarily taken away (cited in Ahmad, 1967:24).

A constitution was finally passed in 1956, naming the country the Islamic Republic of Pakistan. The document contained many references to Islam, but except for a requirement that the President be a Muslim, these references were largely symbolic and non-binding. The government was to enable Muslims to order their lives according to the Quran and Sunnah, and to "promote observance of Islamic Moral Standards." The Constitution specified that no laws were to be enacted that were repugnant to the injunctions of Islam, but it did not specify a body of ulama with the authority to review laws and determine their conformity with Islam and avoided any reference to "shariat." A Commission was to be appointed to study ways of bringing laws into conformity with Islam and an organization for Islamic research was to be established, though neither of these provisions was carried out. There were clauses prohibiting discrimination on the 
basis of religion and guaranteeing freedom to profess and practice any religion. Ahmad (1967:243) and Mehdi (1994) refer to this document as a compromise between the ulama and Islamic modernists, with promises to involve the ulama in law-making, but nothing more specific. The constitution's preamble was disconcerting for some secularists, stating: "Whereas sovereignty over the entire Universe belongs to Allah Almighty alone, and the authority to be exercised by the people of Pakistan within the limits prescribed by him is a sacred trust." For Islamic Modernists, the constitution was sufficient to ensure the supremacy of parliament, while explicitly referencing Islam as the moral basis of the nation. Pakistan's state leadership also believed that strong references to Islam provided a constitutional buffer against communism. This constitution was short-lived, but it became a draft that was modified for two further constitutions in 1962 and 1973.

\section{Women and Nation-Building: Creating "the Social"}

Apart from a few women from high profile families, there were few women in government employment during the period under discussion in this chapter. Women were required to leave the bureaucracy after marriage, and were kept entirely out of departments deemed to be masculine preserves such as the Foreign Service. This is not to say, however, that women played a marginal role in politics. In fact, women's organizations played a central role in nation-building in the post-independence context. Women's groups composed of upper and middle class women from politically active families promoted notions of individual responsibility, citizenship and national subjectivity, not so much through direct involvement in politics as through literacy training, family planning, training women in "domestic science," and other types of social and educational work, and by lobbying the government for legal changes to 
regularize the conduct of affairs within the family through legislation on marriage, child custody, divorce and inheritance (Rouse, 1998).

A number of women's welfare organizations were formed in the years following independence. The largest and best known was the All Pakistan Women's Association (APWA), founded in 1948 out of the Women's Voluntary Services, a relief organization working with the partition refugees. At the time of partition, women's organizations served the new nation by helping in the process of reordering lives around the new borders, providing charity and relief work, and arranging marriages for women in refugee camps so that "no woman left the camp single" (Ansari, 2009:1437). APWA continued as a lobby group for women's legal and constitutional rights, as well as a provider of services to women in and around urban and some rural areas. Women whose families were politically well-connected formed the bulk of the leadership, including Rana Liaquat Ali Khan, the wife of the country's first Prime Minister, while women from other social backgrounds were involved in the organization through its cultural, educational and health and welfare programs and activities.

In a 1953 speech, Rana Liaquat Ali Khan summed up the role of APWA in fostering the social through responsibilizing women and making them aware of the nation:

If I were to choose just one achievement to justify the existence of A.P.W.A. it is that, incontrovertibly, it has been the means of arousing a social consciousness among the women of Pakistan - a social consciousness which has brought thousands of women out of seclusion, idleness and indifference into a life of greater self-reliance and service to the nation" (Khan, n.d., 49).

APWA's activities were geared toward imparting a certain degree of economic selfsufficiency to women in urban contexts, as well as "citizenship education," and education 
on proper domestic practice (Woodsmall, 1960:137). For example, one APWA pamphlet, produced by the Punjab branch, described how adult literacy centres run by APWA in and around Lahore not only served to improve literacy skills, but also:

...become places of hope and enlightenment in the fields of personal hygiene, care of surroundings, nutrition, mother and child care and family welfare...Emphasis is laid on religious instruction so that women can learn to mold their lives accordingly. Women are also enlightened about their duties, responsibilities and rights both social, legal and religious (All Pakistan Women's Association Punjab, 1994:9).

Literacy training, as well as "Mothers' Clubs" run by APWA, provided contexts for making modern subjects through teaching a combination of domestic science and child rearing together with a reformed Islam emphasizing individual rights and responsibilities.

APWA was a strong lobby in official circles. It received government support for social welfare activities, as well as support from international donors. The Ford Foundation, for example, provided funding to establish Home Economics colleges for women in Karachi, Lahore and Dacca. With funds from the Pakistan government and international sources, APWA also set up primary schools, women's hostels, health clinics, and centres for teaching secretarial skills, cooking, sewing, and the production and marketing of handicrafts.

Several other women's organizations appeared at this time whose activities were built around imparting an inter-linked sense of national identity and moral character. These included the Young Women's Christian Association (YWCA) and the Pakistan Girl Guides' Association, both of which existed prior to independence and were reconstituted in 1947 in alignment with the new territorial boundaries. Advice on mothering was also dispensed by the Pakistan Red Cross Society established in 1948, and the Family Planning Association established in 1953. The latter was formed in part with 
the objective of promoting contraceptive use among poorer women. Its stated purpose was:

(a) To encourage families to have children, provided the parents have the health and means to give them reasonable chance in life so that they become an asset to the nation.

(b) To advocate and promote known scientific methods by which people may space their families, thus avoiding the evils of under-feeding, and over-crowding or limit their families where further pregnancies involve risks to the mother. (Woodsmall, 1960:143).

Family planning provided a means of influencing the circumstances of reproduction to the benefit of the nation. Women were to be self-reliant and bear children, but only those children who would not be a burden to the country. Rana Liaquat Ali Khan listed family planning as an key component of women's service to the nation: "No plan for economic development, however grandiose, can succeed in raising the standards of living, if the population is allowed to grow unchecked" (Khan, n.d.:318). An APWA member I interviewed emphasized how activities such as literacy training and family planning help integrate women into society: "We really feel that the more women can be made literate, the more they can reduce the number of childbirths, the better chance they have in life to be good citizens and to influence society" (Interview 14).

In addition to social welfare work APWA joined with another organization, the United Front for Women's Rights, to campaign for women's rights to inherit land in opposition to existing customary practice. ${ }^{13}$ They situated their demands within Islam, asserting that it was custom that denied rights to women, not Islam. The Muslim Personal Law of Shariat eventually passed in 1951, although court rulings based on customary law continued (Jalal, 1991:87).

${ }^{13}$ This type of property was left out of the 1937 Muslim Shariat Application Act. 
APWA also became involved in efforts to regularize marriage and especially to curtail polygamy and regulate divorce, arguing that women could not play their role as citizens if they lived under constant threat of being discarded or displaced from their domestic role through easy, unilateral divorce or through the taking of second wives. In 1954, when the Prime Minister, Mohammad Ali Bogra, married a second wife despite the protest of his first wife (also an APWA member), APWA launched protests in cities throughout the country and demonstrated outside the Prime Minister's house. This was not the example the government was supposed to set if women's rights were to be protected within the family, and was particularly objectionable in that the second wife was not even Pakistani. APWA was at pains to demonstrate that domestic harmony and stability "had to be preserved for the nation to develop and prosper" (Ansari, 2009:1447). Their protest forced the appointment of a Commission on Family Laws in 1956. The report made several recommendations that had been called for by women's groups to restrict polygamy and regulate divorce, but was not implemented, partly because the central government did not have the political strength to overcome strong opposition to the Commission's suggestions (Jalal, 1991:93). The strongest opponents of the recommendations were the ulama and the Jamaat-i-Islami whose defense of polygyny included the claim that it was a way of rehabilitating the "fallen women" of Partition. However, APWA did not see the issue of polygyny as a problem among religious men so much as nationalist men. APWA members accused men in their own social circles of taking second wives at a greater rate since the formation of Pakistan as a quick means to acquire more "modern" wives to match their newfound stature as national leaders (Ansari, 2009:1449). 
The opposition of women's groups to the second marriage of the Prime Minister indicates the close connection they drew between individual conduct and the health of the nation. This is evident as well in the social and educational work that women's organizations did, which attempted to impart an understanding to women that their health was the health of the nation; their economic self-sufficiency was the economic success of the nation; their honour was the honour of the nation; the children they raised were the future of the nation. Women's groups were shaping the social by linking individual conduct and responsibility to the moral collective of the nation. Membership and participation in women's welfare organizations did not exceed a small percentage of the country's population, yet APWA and other organizations achieved a high profile within the public consciousness they played a part in constructing. Social welfare functions were not incorporated into the state at this time and APWA was the locus for much of the social work carried out in the country. APWA maintained close linkages with a succession of governments, obtaining government funding for its activities and government support for further reforms to family law discussed later in this chapter. They thus become a symbol for Islamists of everything that was wrong with the political project of Muslim nationalism.

\section{Geopolitics and State-Building}

The post-war geopolitical context played a major role in creating both the military and bureaucracy in Pakistan. Although efforts were begun to "nationalize" the army, many British officers remained in the army after independence. The Pakistan Army, as a key national institution, had yet to be created, and building the army figured foremost in post-independence institution-building. Within a year of independence, 
Pakistan and India were at war over Kashmir. There was a perception that India won this war because of its greater armament supplies and that: "Given an opportunity to correct this imbalance, the martial Muslims of Pakistan would surely march to victory" (TahirKheli, 1982:12). Every year from 1947 to 1959, defence expenditure was between fiftyone and seventy-three percent of total annual government expenditure (Rizvi, 2000:57). Though a premium was placed on the defence of Pakistan, the martial Muslim was a strictly masculine ideal. This was evident in the response to Rana Liaquat Ali Khan's attempts to involve women in the military defense of Pakistan. She oversaw the formation of the Pakistan Women's National Guard and the Pakistan Women's Naval Reserve in 1949. While hundreds of women joined these wings of the military, strong public opposition resulted in the units being hastily disbanded when Rana Liaquat Ali left the country on a diplomatic posting in 1954. Mumtaz and Shaheed (1987: 51-52) identify several contraventions of prevailing gender norms, including the uniforms the women wore, the public interaction between unrelated women and men, and the fact that the women were paid for this form of national service, unlike the voluntary activities associated with APWA and other women's organizations. Finally, training in weapons use and military communication techniques posed a challenge to the dominant ideal of women as nurturers and threatened to render effeminate the masculine warrior ideal. Male and female ideal national subjects were to remain separate and distinct.

Shortly after independence, Pakistan began to turn to the United States for military support and in the hope of finding an ally to support its interests in relation to India. The projection of Pakistan's national identity in the international arena was beginning to take on a strongly military flavour. Just as the British promoted the warrior 
race theory for their own defence, Tahir-Kheli (1982) suggests that this view took hold within US foreign policy circles as well. The martial Muslims of the Indian subcontinent were not only defending their faith and traditions but were also becoming warriors in the fight against communism:

For many, in both Pakistan and the West, Pakistan has stood as one of the natural bastions of anticommunism. Islam has long been thought to confer a natural immunity to communism, and Pakistan was at once both explicitly Muslim and wedged between the world's two great communist powers (Cohen, 1984:8-9).

That the Pakistan Army saw itself as defending Islam as well as Pakistan was not a problem in the eyes of western funders.

However, there was by no means consensus within Pakistan that an alliance with the US was the proper course to follow. Many early upheavals within Pakistan's top military and political leadership have been attributed to attempts by the US and Britain to protect their interests in Pakistan. These include theories about the 1951 Rawalpindi Conspiracy which resulted in a purge of senior ranks in the Pakistan military for supposedly planning to align Pakistan with the Soviet Union and its allies. Jalal (1990) suggests that the U.S. and Britain were heavily involved in the latter, and this international involvement was partly responsible for creating a political climate in Pakistan in which those critical of the government or of foreign powers were accused of sabotaging the new state or promoting communism.

American and British interests in Pakistan were focused on the Pakistan military and, in the case of Britain, protecting its significant oil interests in neighbouring Iran. A strong Pakistan Army was a major objective, an army that could be sent into Iran if necessary, according to the American State Department, to "fulfill one of the traditional functions of British-Indian troops in past wars" (Jalal, 1990:127). While Pakistan sought 
military aid to fortify its borders and strengthen its position vis-à-vis India and Afghanistan, Britain, with its oil interests in Iran and strategic-military interests in Egypt under threat from nationalist movements in both countries, sought assurances from the Pakistan government in 1951 that it would commit troops to any future war in the Middle East before it would consider granting military assistance to Pakistan.

During the 1950s, Pakistan entered military alliances with the United States, Britain and France, incurring anger from many non-western leaders and resulting in large demonstrations in Pakistan, particularly in 1956 when Pakistan sided with its defence pact allies, Britain and France, during the Suez conflict. Pakistan's military became an important proxy, deploying in contexts such as Saudi Arabia where the United States desired a military presence but did not want an open American presence due to negative public response. Western commitment to a strong military in Pakistan extended to the training of Pakistani military officers, initially in Britain, and then in the United States. Pakistan also permitted the use of its territory as a base for American military operations and entered into numerous military pacts with western governments; strangely given that the United States would never support Pakistan in a conflict with its main military antagonist, India. ${ }^{14}$

Pakistan's strategic importance led not only to military alliances with the U.S. and its allies, but also to heavy involvement of western academics, particularly economists, in government planning and policy in Pakistan. Organizations such as the Ford Foundation

\footnotetext{
${ }^{14}$ The United States made it clear that it would not support Pakistan in any conflict with India and, in fact, stopped all military aid to Pakistan at the time of the 1965 IndoPakistan war. Despite its membership in SEATO and CENTO, Pakistan was left to fight the better-armed Indian military on its own and the United States discouraged more sympathetic defense pact members, such as Iran and Turkey, from providing any assistance to Pakistan.
} 
were established in the United States in the post-war period with mandates to assist new countries to "develop", thus steering them away from communism. South Asia became a crucial laboratory for experimenting with the new knowledge system of development economics, with the American government claiming it did not want to "lose India, as we lost China" (Rosen, 1985:11). The new knowledge system was allied with political centralization, emphasizing the need for the new states to "succeed"; for there to be stability and capacity for self-government allied to western international objectives. The extent of American interest in maintaining the central government in Pakistan was evident in the timing of aid to coincide with the 1954 provincial elections (Jalal, 1990:188-89). In Pakistan the emphasis was on training leaders and experts in new knowledge systems and providing western experts themselves with a forum to develop the theory and practice of development economics.

The Ford Foundation funded an Advisory Group from Harvard University to assist the Government of Pakistan in writing its first Five Year Plan and to set up a Pakistani planning agency. The Pakistan Institute of Development Economics was established with Ford Foundation funding to establish the discipline of economics in Pakistan. The Foundation also funded collaborations between Pakistan's government and various American universities to establish two rural development academies and the Pakistan Administrative Staff College. The latter was to train civil servants in the new role of government administration, the relationship between administrators and citizens, and the place of government administrators in the development and modernization model promoted by international agencies. Braibanti (1966) credited the initiatives of American universities, the Ford Foundation, and the United States Agency for International 
Development (USAID) with creating the government bureaucracy of Pakistan.

Western interests were in perpetuating a militarized Pakistan, with a central role for Islam in political discourse, to further a capitalist development model and forestall communism. There were, however, few linkages between the people of Pakistan and this government concerned with security, weapons and military strength and ruled by an elite of civil servants. The dependence on the United States meant that the central elite wanted to suppress any domestic political developments that could endanger financial and military aid (Jalal, 1990:300-301). Public anger at the country's foreign policy combined with food shortages and a severe economic crisis fueled political conflict. In 1958 violence broke out in the East Pakistan legislature, resulting in the death of the Deputy Speaker. Even among the small proportion of Pakistanis involved in the national political field the legitimacy of central rule in Pakistan was undermined to such an extent that the head of the army, Mohammad Ayub Khan, abrogated the 1956 Constitution and declared marital law in Pakistan in 1958.

\section{The "Decade of Development," 1958-69}

Ayub Khan assumed the office of President and remained head of state until 1969. Arguing that politicians had worked in their own self-interest and had failed to serve the national cause, Ayub banned political parties, abolished the office of Prime Minister, and promulgated his own version of PRODA, the Public Offices (Disqualification) and Elective Bodies (Disqualification) Orders of 1959, to prevent politicians deemed to be corrupt from seeking future office. Although he was head of the military, Ayub did not involve the military strongly in his government. He did not wear a military uniform, emphasize his military background, or have many military officers serving in his 
administration. Instead, he sidelined squabbling politicians so that "experts" could function unimpeded in applying the knowledge systems they believed would foster national consciousness, economic growth and political centralization, including development economics and modernization theory. Ayub sought to create a direct relationship between bureaucrats who were "the group that personified modernity, education and national orientation" (Ziring, 1971:153) and Pakistan's largely rural population who appeared to be particularly unmindful of the nation and the central government. He believed that a disciplined bureaucracy, trained in the national ethos, would teach citizenship and national orientation, and help centralize the country. This administrative approach to state-building would also circumvent the endless constitutional wrangling that had allowed a point of entry for the ulama whose vision for Pakistan's government was not shared by liberal bureaucrats.

Ayub's tenure in power was promoted as the "Decade of Development," which was not only the approach of his government to stimulating the economy, but also to state-building by linking up villages through government-managed development schemes. In order to accomplish this, Ayub restructured political administration in the form of "Basic Democracies." This system, established in 1959, consisted of 80,000 local Union Councils in rural areas and Union Committees in urban areas. Members of these councils were to be elected on the basis of universal adult franchise, although the central government could also appoint members. Several Union Councils were grouped into Tehsil or Thana Councils composed of chairmen of the Union Councils and governmentappointed officers. Above these there were District Councils, again composed of appointed civil servants and chairmen of Tehsil and Thana Councils. Thus, Ayub devised 
a means of linking elected representatives with civil servants, all under the influence of the central government and its bureaucracy. Union Councils and Committees were to oversee development schemes, thereby supposedly creating direct linkages with the population. The Basic Democracies model combined three approaches to local government: 1) government-supervised cooperative societies; 2) "rural uplift" emphasizing self-help, community development and the generation of "enthusiasm and an ideology which would sustain improvement in all aspects of village life"; and 3) local self-government, a bureaucratic-legal approach legitimized by law and formal elections (Braibanti, 1966:156).

This system was intended to "create a new politically conscious class of leaders with administrative skills capable of mobilizing the rural population" (Ziring, 1971:15). Heavily influenced by modernization theory, these measures reflected the assumption that "traditional attitudes" were the major barrier to state-building. Government officers, trained in the United States, or in colleges and programs established under the guidance of western experts, were to change the attitudes of rural inhabitants and make them conscious of their role in national development. Government officers also needed attitudinal training according to modernization theorists to learn to view the public as citizens rather than subjects, and to understand the government as embodying the welfare of the citizen (Inayatullah, 1964). This was intended to circumvent local political structures based on kinship or patronage systems, and to further national cohesion by bringing the entire country under one uniform system of administration for the first time.

\section{Education and Family Law: The Role of the Housewife in Modernization}

Ayub Khan promoted the clearly demarcated, not blurred, gender practices 
associated with modern domesticity - the male breadwinner and the housewife - through educational policy and by strengthening the legal basis for companionate marriage. The 1959 Report of the Commission on National Education, drafted by representatives from business and industry, as well as foreign "experts," outlined what types of workers would be needed for a capitalist economy and how they should be created (Saigol, 1995). It also described the character and attitudes necessary for citizenship and the central role women were to play in their transmission. Women as wives and mothers were to play a crucial role in fostering the nation. First, however, they had to be trained as housewives.

The educational policy set out a gender specific curriculum for girls, emphasizing first aid, needlework, cooking, and the sciences of child psychology, dietetics and household management, beginning in the middle grades and continuing through high school and higher levels of education. The report states that mothers must be educated to create an educated community, that they are crucial in shaping the "character and capability" of children, and are best suited "emotionally and temperamentally" to the task (Government of Pakistan, 1960:187). A section of the report on "The Obligations of Women" states that women must accept the responsibility of creating the ideal citizen:

...it is imperative that she inculcate in him from his earliest days those habits and attitudes which are essential for the development of the country and the well-being of its citizens. She must impress on him the importance of cleanliness, truthfulness, honesty, co-operation, and a desire to learn and improve himself and his community" (Government of Pakistan, 1960:192).

Foreign involvement in drafting the policy is perhaps the reason for the document's statement - strangely out of place - that mothers should become involved in parentteacher associations and school advisory committees. Economic decisions made in consultation with international agencies, entirely disregarded the necessity for women to 
work, as well as their crucial role in agriculture (Rouse, 1992). This policy became the basis for educational policies that never diverged under subsequent administrations from this emphasis on training women as housewives, with its underlying assumption that women exist in middle class households, not families that are themselves productive units in an agrarian economy.

Some of the recommendations of the 1956 Commission on Family Laws were finally enacted under the Muslim Family Law Ordinance of 1961. The MFLO granted women some minimal rights with regard to marriage and divorce. For example, the minimum age of marriage for women was raised from fourteen to sixteen; the law proclaimed that men could not divorce their wives through verbal repudiation; and men were required to obtain a first wife's consent before taking additional wives. In addition to legally supporting notions of companionate marriage, family law reform and its bureaucratic application provided a point of entry into individual lives. Ayub Khan assigned the tasks of licensing and registering marriages and divorces to the Basic Democracies, an important modification to the structure of local administration (Braibanti, 1966:315). In fact, the MFLO was an important component of the Basic Democracies scheme for installing bureaucrats at a local level to administer and arbitrate local affairs. It was passed at the same time as the Conciliation Courts Ordinance (1961), and the two ordinances together granted power to the Basic Democracies to preside over local disputes (Ziring, 1971).

There were many barriers to the implementation and effectiveness of the MFLO provisions. Penalties were minor, second marriages were not legally affected if a first wife complained, and there was no mechanism for awarding compensation or 
maintenance to women after divorce, making it legal but rarely feasible for women to initiate divorce (Jilani et al, 1988). As with earlier legal reforms, there was also no way of ensuring that local judges would actually incorporate the new laws into their rulings. Family law reforms, together with the government's education policy, remained largely symbolic due to an absence of systematic implementation.

Despite its weak provisions and impact, the MFLO was vehemently opposed by religious parties. The ulama saw this as a further instance of the state appropriating their prerogative to adjudicate matters of personal law. Islamist opponents of the Ordinance argued that raising the minimum age of marriage and restricting polygyny would contribute to extra-marital sexual relations. In defense of the Ordinance, women's organizations argued that the MFLO merely granted them their rights according to the Quran and Sunnah, and recognized women's services to the nation (Chipp-Kraushaar, 1981). APWA wrote letters to, and met with, Assembly members as well as their wives, in an effort to protect the laws from being repealed. However, one member of APWA's national executive reported that Ayub Khan was the only real supporter of the Ordinance within the government, and: "In fact, had it not been for his support, the National Assembly would have voted against its passage, and the numerous attempts to repeal the Laws undoubtedly would have succeeded" (Chipp-Kraushaar, 1981: 279-280). Ayub Khan's alliance with APWA was visible in other ways; Patel (1979) reports that thousands of women gathered outside Ayub's house to cheer him when the MFLO was promulgated and he was invited to inaugurate an APWA conference where he was publicly thanked by women. Thus, publicly the state was seen to be the patron of APWA and its agenda, while APWA was seen as allying itself with the political dispensation of 
the time.

APWA remained vigilant in protecting the law, continuing political pressure and demonstrations in 1962 when the law was reviewed by the Council on Islamic Ideology, and in 1965 when a National Assembly bill came forward to amend the MFLO. The MFLO became a major issue during the 1965 election campaign. An APWA resolution exhorted men to consider their female relations and remember that "The welfare of a nation depends on happy homes" (Chipp-Kraushaar, 1981:278). APWA branches set up their own legal aid services for poorer women to help promote knowledge of the Ordinance. However, few women were able to take advantage of APWA's legal aid or the provisions of the ordinance, leading some to suggest that the greatest impact of the law was psychological, promoting the idea that women had rights and that they would be protected by the state. When Basic Democracies were dissolved by Martial Law Orders in 1971, the MFLO remained in effect but an administrative body to enforce it no longer existed (Patel, 1979).

\section{Islam and Government Policy}

For religious leaders, the MFLO was one of several ways the government usurped their authority. Ayub Khan was less willing than preceding political leaders to accommodate the representatives of Islam in formulating state policy. He re-emphasized that Islamic modernism was the "ideology of Pakistan," not the Islam of the ulama or the Jamaat-i-Islami, and requested that Javed Iqbal, a lawyer and son of nationalist poet Mohammad Iqbal, write a book outlining Islamic modernism. Institutions were established to provide official interpretations of Islam, and the ulama were urged to "interpret religion in ways that were more relevant to the country's developmental agenda 
and that would fight communism" (Nasr, 1994:150). Ayub Khan abrogated the 1956 Constitution, which contained many gains religious groups had lobbied hard for, and immediately changed the name of Pakistan from the Islamic Republic of Pakistan to the Republic of Pakistan. The "West Pakistan Waqf Properties Ordinance" of 1959 gave the government direct control over religious properties, such as shrines and mosques. After further angering religious groups with the enactment of the Muslim Family Laws Ordinance in 1961, he repealed martial law and promulgated his own constitution in 1962 without dialogue with religious parties whom he openly opposed. In 1967, the government usurped the power of the ulama to determine when the moon ending Ramadan, the Muslim month of fasting, had been sighted. ${ }^{15}$ Maududi was among several religious leaders jailed for protesting this decision.

Government policies challenged the authority of Sufi pirs as well as the ulama. Pamphlets written and distributed by the government at the shrines of saints attempted to modernize Sufism. Ewing writes: "[The pamphlets] do not give accounts of the miracles performed by the saint. Rather, they stress the saint's pious actions ... actions that do not violate a modern, scientific worldview" (1997:71). The government pamphlets also gave the shrines and saints a universalistic orientation, removing the particularities of "caste, creed, or geographical region", to which the authority of saints is usually confined (Ibid:72). Ayub Khan also tried to attach social welfare and scientific educational functions to the shrines by involving them in hospitals, schools, agricultural fairs, industrial exhibitions, libraries and research centres.

\footnotetext{
${ }^{15}$ It was an embarrassment to the government, and not conducive to a "national holiday," to have this most important date observed differently across the country, and so a government body was established to provide a sole verdict on the sighting (Ziring, 1971:182).
} 
Elections for President were held in 1965. The opposition to Ayub Khan united behind the candidacy of Fatima Jinnah who, while not active in politics, was recruited to oppose Ayub Khan in elections because of her popular appeal as the sister of Mohammad Ali Jinnah. Although she gathered large crowds while campaigning, she lost to Ayub Khan in the electoral college of Basic Democrats. Interestingly, many religious parties joined the Combined Opposition Parties including the Jamaat-i-Islami. Not letting his ideology stand in the way of his hatred of Ayub Khan, Maududi explained that a woman could be head of state in "extraordinary circumstances." Meanwhile, despite his reputation as a champion of women's rights and Islamic modernism, Ayub Khan arranged for a number of ulama to issue fatawas against a woman head of state (Mumtaz and Shaheed, 1987:60).

\section{Class and Ethnic Inequalities}

Both Basic Democracies and the Decade of Development backfired. Rural development programs were generally much more successful in East Pakistan than in West Pakistan where the power of landlords created a bloc of resistance to reconstituting political authority in this way. In fact, landlords came to dominate the Union Councils in much the same way that they had previously dominated provincial assemblies. While seeking to involve people in the nation, it was the elite civil service and military, together with their appointed experts, who were to make decisions and set priorities. Political activists were jailed and newspapers were shut down or brought under government control. Growing economic disparities were produced by the development philosophy pursued at this time, characterized by the well-known statement of a senior Ayub-era economic planner: "The underdeveloped countries must consciously accept a philosophy 
of growth and shelve for the distant future all ideas of equitable distribution and welfare state" (Haq, 1963:30). Gross National Product figures did increase under Ayub Khan, but few saw the benefits of this economic success. The extreme concentration of wealth in the country resulted in the popular unrest that played a major role in forcing Ayub Khan to resign. The heavy reliance on foreign capital and foreign governments to set priorities in Pakistan was resented widely for many reasons, including for discouraging investment in social welfare. Green Revolution agricultural policies promoted by foreign experts caused greater class disparity, large-scale migration to urban areas, unemployment, increased dependency on wage labour, and the erosion of living standards for most of the population. ${ }^{16}$ The government's participation as a Cold War ally of the west had led to the suppression of popular political movements in Pakistan and the allocation of enormous amounts of the country's scarce resources to the military.

Income disparities increased during Ayub's time, not only between rich and poor overall, but also between West and East Pakistan. East Pakistanis continued to be underrepresented in the military and bureaucracy, and lost their major avenue to national level political power - the elected institutions (Jahan, 1972:61-62,180). The suppression of the Bengali language, and racist state policy viewing Bengalis as inferior, continued under Ayub Khan. A Bureau for National Reconstruction was given the task of changing the Bengali language to remove Hindu/Sanskrit influences and to increase the content of the privileged Muslim languages of Arabic, Persian and Urdu. The government also pursued a policy of "assimilation-through-miscegenation," offering financial incentives for

\footnotetext{
${ }^{16}$ For example, mechanical cultivation on large landholdings displaced sharecroppers and tenants. Large landowners saw their incomes rise substantially. As the largest sector of the economy, their increased consumption resulted in inflation which further decreased the living standards of smaller farmers and wage and salary earners (Alavi, 1976).
} 
marriages between East and West Pakistanis (Kabeer, 1991). Displaying his belief in the racial and cultural inferiority of Bengalis, Ayub Khan wrote:

It would be no exaggeration to say that up to the creation of Pakistan, [East Bengalis] had not known any real freedom or sovereignty. They have been in turn ruled either by the caste Hindus, Moghuls, Pathans, or the British. In addition they have been and still are under considerable Hindu cultural and linguistic influence. As such they have all the inhibitions of down-trodden races and have not yet found it possible to adjust psychologically to the requirements of the new-born freedom. Their popular complexes, exclusiveness, suspicion and a sort of defensive aggressiveness probably emerge from this historical background

The population in West Pakistan, on the other hand, is probably the greatest mixture of races found anywhere in the world. Lying on the gateways to the Indian subcontinent, it was inevitable that each successive conquering race should have left its traces here. Consequently, this forced mixture of races has brought about fusion of ideas, outlook and culture, despite the linguistic variety obtained (Ayub Khan, 1967:187).

Ayub's writing reveals the centrality of warrior race mythology in his outlook, a mythology that had a natural home and appeal in Pakistan's military. Also implicit in his remarks on the "forced mixture of races" is a justification for the rape and conquest that were soon to be exercised on a large scale by the Pakistan Army in Bengal.

\section{Elections and Civil War, 1969-71}

In the context of growing challenges to government authority resulting from linguistic, ethnic and socio-economic tensions, foreign development experts began to pull out of Pakistan. Ayub Khan stepped down in 1969, after widespread protest against his regime and the worsening economic situation of the majority of the population. The head of the military, General Yahya Khan, re-established martial law. In December, 1970, national elections were held in which the Awami League of East Pakistan won the majority of seats in the National Assembly, followed by the Pakistan People's Party (PPP). The Awami League demanded a greater political voice for Bengalis and 
recognition of Bengali grievances, while the PPP foregrounded socialist demands infused with talk of Islam and social justice. Both parties were "regional"; that is, the Awami League existed as a party in East Pakistan only, and the PPP only in West Pakistan. The Jamaat-i-Islami also contested the elections, winning four of the 151 National Assembly seats it contested, and four of 331 Provincial Assembly seats, under-performing two smaller religious parties, the Jamaat-Ulama-e-Pakistan and the Jamaat-Ulama-i-Islam.

Winning all but two seats in the more populous East Pakistan, the Awami League was able to obtain an absolute majority in the National Assembly. The prospect of a national government led by East Pakistan was not anticipated by the military leadership and Yahya Khan delayed calling the National Assembly to session. Zulfikar Ali Bhutto, the leader of the PPP, proposed a joint national government led in East Pakistan by the Awami League and in West Pakistan by Bhutto and his party. This was rejected by Awami leader, Mujib-ur-Rehman, and Bhutto announced a PPP boycott of any National Assembly sessions. Yahya Khan rejected the election results and instituted Emergency Rule, adding further fuel to the independence movement in East Pakistan. On March 25, 1971, the Pakistan Army attacked Dacca University, a key site of mobilization for Bengali independence, killing many civilians, and arresting Mujib. The following day Mujib declared East Pakistan's independence and a bloody nine-month war ensued as the Pakistan Army mobilized to suppress the independence movement. The Jamaat-i-Islami joined with the Pakistan Army to fight Bengali nationalism, particularly the East Pakistan wing of the party, which saw a potential decline in its fortunes if Bengali nationalism were to win out over Islamic unity. The Jamaat-i-Islami joined the military government in East Pakistan and, along with the IJT (the party's student wing), formed paramilitary 
organizations to support the Pakistan Army.

Estimates suggest that tens of thousands of women were raped by Pakistan Army troops (Kabeer, 1991). As was the case at partition, rape was used as a means of dishonouring the enemy, subverting their independence by instilling the seeds of the enemy into their bloodlines (Saigol, 1995). The nine-month war came to an end when the Indian army intervened, sending troops into East Pakistan to support the Bengali fighters. The Pakistan military was defeated, surrendering to its arch-rival on its own territory, and the state of Bangladesh (independent Bengal) was created. Pakistan, the purported homeland of South Asian Muslims, now had a smaller Muslim population than either India or Bangladesh. The Jamaat-i-Islami and parts of the Army perceived that a lack of adherence to Islam among the country's leadership, and moral lapses such as drinking alcohol and "womanizing" (Nasr, 1994:171), had led to the defeat in East Pakistan. The Pakistan People's Party was permitted to form a national government in West Pakistan, now Pakistan, on December 20, 1971.

\section{Conclusion}

In this chapter I have discussed the multiple challenges faced by the new state of Pakistan in political centralization and nation-building and the role that middle class women's organizations played in both efforts. Pakistan's borders were insecure at the outset of independence, Muslim nationalism was not a strong movement in the territories that became Pakistan, and the country inherited models of administration from the colonial state that had localized power. Pakistan's early state executives sought to build a strong military to defend the country and, faced with the power of local intermediaries backing demands for regional autonomy, proceeded to rule in a way that mimicked the 
colonial state whose political centre had been characterized by strong administrators seeking to assert their authority over elected parliaments. An additional problem was the continuation of debates among Muslim nationalists, ulama and Islamists over what a Muslim polity meant. Middle class women's organizations played a role in this context in marshalling support for nation-building. Mohammad Ayub Khan, who made political centralization his focus, developed a system of administration that made use of bureaucrats to supervise politicians and pursue a policy of state-building that relied on foreign experts and the application of the knowledge systems of development economics and modernization theory. Family law assumed an important place in this bureaucratic model for extending the reach of the state. Education and social welfare were not priorities. These knowledge systems impoverished many and this period saw the rise of multiple forms of popular protest, Bengali nationalism and socialism key among them. Though the political leadership during most of this period was secular, a relationship between the military and Islam was fostered to put down popular movements and suppress communism, and this relationship was further concretized in the context of the war in Bangladesh. In the next chapter, I discuss the emergence of a more distributive political regime and model of state building, incorporating components of socialism and state feminism. Opposition to this regime would come to organize greatly around concern with the increased visibility of women in an expanding public sector, and to be articulated through Islamist discourse. 


\section{Chapter Four \\ The "People's Government": Populism and State Feminism, 1971-1977}

\section{Introduction}

Pakistan's first democratic national elections held in 1970 demonstrated widespread support for political parties that emphasized regional autonomy and socialism, translating into victories for the Bengali nationalist Awami League in East Pakistan, the socialist Pakistan People's Party (PPP) in Punjab and Sindh, and the leftleaning and pro-regional autonomy National Awami Party (NAP) in Baluchistan, and NWFP. ${ }^{1}$ On December 20, 1971, the PPP formed the government in what remained of Pakistan after the secession of Bangladesh, and the elitism of the Ayub period of planners and bureaucrats gave way to the "populism" of Zulfiqar Ali Bhutto. The PPP proceeded to nationalize major industries and financial institutions, carried out some land reforms, and introduced some components of a welfare state early in its administration. The government also introduced components of "state feminism," a policy program that attempts to further women's integration into production and the labour market, and to "de-privatize" reproduction, through a combination of expanded public sector employment of women and policies such as child care, maternity leave, and access to abortion (Hatem, 1992). The PPP also demonstrated a degree of responsiveness to the continuing demands of women's groups for further legislation to protect women's economic interests within the family.

Yet, Bhutto's rule is often referred to as "dictatorial populism" because of his authoritarianism and use of force to suppress and intimidate protesters and opponents, his

${ }^{1}$ In the NWFP, the NAP won the largest number of seats in the provincial assembly, but federally, more seats went to the Jamaat-ul-Ulama-i-Islam and a faction of the Muslim League (Syed, 1992:80-81). 
attempts to bring major government institutions under his direct control, and his efforts to cultivate broad-based legitimacy and direct loyalty to the government through popular appeals to socialism, Islam, anti-imperialism, and an often jingoistic brand of nationalism. Unlike the liberal state executives that preceded him, Bhutto was more inclined to legislate Islamic conduct, although his version of Islamization did not focus on the conduct of women. By 1974 Bhutto began to cultivate a stronger support base among the rural elite and socialists were marginalized within the government. Yet, because of the first-ever legitimacy of socialism within state policy and discourse, the period of Z.A. Bhutto's PPP government is remembered by many in Pakistan as a period of democracy and expanded class consciousness among poor and working people. In this chapter I describe the contradictions of the Bhutto period, with its heightened credence given to socialism and feminism, as well as increased militarization and Islamization. I also describe how opposition to the PPP's program of creating a strong central state with a large public sector and a "mixed economy" - and the accompanying gender order that blurred distinctions between public and private/domestic, productive and reproductive, and masculine and feminine - coalesced around a discourse that emphasized the need to introduce an "Islamic system," protect private property, and return women to the home.

\section{Emergence of the PPP}

The PPP was formed in 1967 by Zulfikar Ali Bhutto, a lawyer and Sindhi landlord who had been Ayub Khan's foreign minister. Relations between Ayub and Bhutto had been strained since the 1965 war with India - a war that Bhutto had 
encouraged Ayub to pursue (Syed, 1992). ${ }^{2}$ Throughout the decade of Ayub Khan's rule there was growing anger directed against elites in the military, state bureaucracy, industry and finance, as well as western powers. The first grassroots protest movements in Pakistan's history reached a high point around 1968-69 among peasants, workers, and students (Alavi, 1983:86). The 1970 election manifesto of the PPP included much talk of socialism, and the need to transcend capitalism and neocolonialism. It proposed withdrawal from military pacts with Western countries, and an end to the use of Pakistan as a base for military activities by foreign powers. It called for the nationalization of heavy resource and manufacturing industries, of transportation, and of all banks and insurance companies. It included a section on trade union rights and called for a minimum wage, old age pensions, and child care for employed women. The party was strongly associated at the popular level with the election slogan, "roti, kapra, aor makan" (bread, clothing and shelter). The Muslim League joined the Islamic parties in campaigning on a platform of Islam versus socialism (Syed, 1992:69).

The PPP won 81 of 138 seats in West Pakistan in 1970, mostly in the provinces of Punjab and Sindh. This result, and the even more impressive majority obtained by the Awami League in East Pakistan, came as a shock to the military leadership whose locallevel intelligence gathering had led them to expect a fractious, multi-party National Assembly with a better showing for their preferred parties (the religious parties and the Muslim League), enabling the military to continue to oversee the elected government (Nawaz, 2008:258-264). As discussed in the previous chapter, the military could not

\footnotetext{
${ }^{2}$ In September of 1965, when Pakistan launched an incursion across the contested Kashmiri border, India responded not only in Kashmir, but sent tanks across the international border in Punjab and launched an aerial attack on the city of Lahore. The brief war resulted in no gains for Pakistan, but abruptly ended American military aid to both countries.
} 
accept the majority victory of the Awami League. Neither could Bhutto, who proposed that the People's Party form the government in West Pakistan and the Awami League in East Pakistan. After their surrender to the Indian army and the creation of Bangladesh, a divided and demoralized military leadership relinquished control to civilian government. In late December of 1971, the PPP formed Pakistan's first democratically elected national government.

Within four months of assuming power in 1971, the government had nationalized a number of industries and announced labour and land reforms. Bhutto also instituted procedures to remove government office holders deemed to be corrupt; however, this time it was civil servants, not politicians, who were the target. In March of 1972, Bhutto removed over 1300 civil servants from office on charges of corruption or incompetence. He later instituted administrative reforms that weakened the autonomy and power of the civil service and allowed appointments to the bureaucracy of people who were not members of the Civil Service of Pakistan. Bhutto also made changes to the senior ranks of the military, including dismissing some senior officers and reducing the length of tenure in office for senior positions. In 1976, he bypassed several more senior generals in choosing General Zia-ul-Haq as the Chief of Army Staff, apparently believing him to be more compliant (Nawaz, 2008:338). He also created a paramilitary alternative to the Army, the Federal Security Force (FSF), which grew in size to 18,000 recruits by 1976 (Nawaz, 2008:343). ${ }^{3}$

Whether or not these reforms had any impact on the power of the bureaucratic and military elite overall is a subject of debate. Changes to the bureaucracy are suggested by

\footnotetext{
${ }^{3}$ On coming to power, one of Zia-ul-Haq's first actions was to disband the FSF (Talbot, 1998:223).
} 
some to have had no impact on the power of this government institution (Jalal, 1995:82; Syed, 1992), although they are lamented by those who take a more favourable view of modernization theory and of the key role of the bureaucracy in promoting a westernized and secular "ethos" (Kennedy, 1987:4). Jalal (1995) suggests that without simultaneous measures to strengthen the judiciary and parliaments, the measures were merely "cosmetic." Alavi (1983) suggests that the key impact was the removal of due process in the institution that ruled Pakistan from independence, enabling increased political patronage and retribution by dictatorial leaders. With the nationalizations carried out by the PPP, the size and reach of the bureaucracy grew.

Military spending increased under Bhutto compared to the already high levels of previous governments, ranging from 42 to 59 percent of annual government expenditure between 1971 and 1977 (Rizvi, 2000:218-219). Rather than reducing the predominance of the military by pursuing a more peaceful foreign policy—and despite his talk of "Third Worldism"-Bhutto's frequently bellicose political stance and rhetoric did nothing to reduce tensions with two of Pakistan's neighbours, India and Afghanistan. Bhutto continued to pursue a policy that emphasized the centrality of war and a tendency to use the military to suppress popular dissent within the country. The two most striking examples of this include his use of the army to suppress tribal leaders in Baluchistan who demanded greater autonomy, and his efforts to develop nuclear weapons in Pakistan. Bhutto made no peace overtures toward India, after two wars (1965 and 1971) in the promotion of which he had personally played some role. Bhutto, in fact, shared the military's core values (Cohen, 2004:79). These included a hostile stance toward India, a nationalistic foregrounding of Islam, and a preference for military operations to defend 
the territorial boundaries of Pakistan from threats, both internal and external. In the case both of the bureaucracy and the military, Bhutto's reform efforts are widely viewed as having been directed not at democratizing political institutions and arrangements, but at bringing the military and bureaucracy under his direct control.

\section{Economic Policy}

The period during which the PPP was in power was one of severe economic crisis in Pakistan in terms of "foreign exchange, commodity markets, money supply generally, and disruption of production and trade" (Ahmad, 1983:109). East Pakistan had been a major market for manufactured goods from West Pakistan, which were not priced to compete internationally, and East Pakistan's jute and tea had been the country's most lucrative exports. The economic policies of the 1960s, aimed at increasing GNP at all costs, resulted in mass migration of displaced agricultural workers to the cities, and greater inequalities of class and region in Pakistan, which fed into the 1971 war (Rouse, 1997:153). These problems were compounded by the oil crisis during the 1970s and the flight of capital from the country resulting from the nationalizations.

Despite the economic crisis, this was a period during which trade unions proliferated and gains were made in wages, benefits and job security. During the Ayub Khan period, unions had been banned in many industries (Burki, 1980:46). Under Bhutto, trade unions and strikes were often violently suppressed, but the party actively promoted the formation of PPP-affiliated trade unions, and more trade unions registered during the first three years of the PPP government than during the preceding two decades (Ahmad, 1983:106). Among the first reforms announced by the PPP after forming the government were labour policies designed to improve and extend legal protection relating to job 
security and payment of wages, and to set up a compulsory system of shop stewards and grievance procedures (Gustafson, 1973). ${ }^{4}$ Although employment declined in the private sector due to the economic crisis, public sector employment expanded under the PPP and legislated improvements in wage scales and benefits in the public sector had an impact in the private sector as well (Ahmad, 1983:106).

Nationalization was a policy that had never been pursued in Pakistan prior to this time. In January of 1972, a number of domestically-owned firms in ten industries were brought under the management of the government bureaucracy, although shareholders retained ownership. Life insurance companies were nationalized in March of 1972 and banks were nationalized in January of 1974. While Ayub Khan had pursued economic growth through private sector expansion and mechanization, the PPP sought to create a "mixed economy" with greater public control of "heavy" industries such as steel and metal industries, heavy machinery, chemicals, fertilizer and cement. Again, many researchers suggest that the main outcome of these reforms was the creation of "channels for patronage" for the PPP leadership (Alavi, 1983; Gustafson, 1973; Noman, 1988:7579), though they also fostered a sense of empowerment among workers and a concomitant fear and hostility within private capital, particularly among some of the larger industrialists targeted by these reforms.

By 1974, most socialists within the PPP had been removed or resigned from the executive of the party, a development associated with Bhutto's attempts to engineer his

\footnotetext{
${ }^{4}$ The direct involvement of the colonial state bureaucracy in industrial relations was retained and expanded after independence. Alavi states that labour relations in Pakistan are characterized by "an elaborate institutional structure that enables the state bureaucracy to be directly involved at every stage in the management and manipulation of industrial relations" through "industrial tribunals, the Labour Department of the government and various bodies, agencies and courts" (1983:56-57).
} 
government's stability by courting large landowners in Punjab who had not been strong supporters of the party in the 1970 election; by 1975-76, the majority of the party's top leadership came from the landed elite (Noman 1988:103-4). Landowners of Punjab and Sindh, staunch supporters of the colonial state, would continue to be courted by governments in the post-independence period for their ability, through a politics based on patron-client relations, to deliver the largest single vote bank in the country: the rural poor, peasants and tenants. Landowners in Punjab and Sindh were not as threatened by the early land reforms undertaken by the PPP as large industrialists had been by nationalizations. The initial land reforms had reduced ceilings on land holdings and redistributed some land to small farmers, but there were exemptions and landowners had various means of circumventing these laws. ${ }^{5}$ Furthermore, Burki (1980) argues that PPP policy discriminated in favour of large landholders through production incentives, investment credit and price support for crops grown on the largest farms. The most significant impact of the PPP land reform initiatives were reducing the share of produce tenant farmers were required to give to landlords (Said Khan, 1995:15) and stopping evictions of tenants, which had become widespread in the late 1960 s with the push to mechanize and increase production of cash crops under "Green Revolution" policies (Rouse, 1983: 314-17; Rouse, 1997:164). Bhutto proposed further land reforms in 1977 that would have collected revenue from the largest land holders who had previously never paid an agricultural income tax (Ahmad, 1983:107-8).

\footnotetext{
${ }^{5}$ Such as portioning out land titles among several family members or surrendering uncultivable land. Noman suggests that joining the PPP was also a way to avoid loss of land holdings as the land reform program became a means to reward supporters and punish opponents (1988:94).
} 


\section{Liberal Rule and State Feminism}

Women had been largely absent from the Ayub Khan government, apart from a handful of appointees, beholden to their leader. There was no drastic change with the 1970 elections, with only 5 women among the 81 elected PPP MNAs. The Bhutto period saw the continuation of what are seemingly contradictory state policies: on the one had the extension of "women's rights" or liberal citizenship rights; and on the other hand, continued allegiance to the notion of the housewife in state policy. As I have suggested previously, the concept of the housewife is a modernist construct; not an assertion of traditional patriarchy, but in fact a direct challenge to traditional forms of patriarchal authority and their political, economic and social arrangements. "Women's rights" and the concept of the housewife both stem from those changes I have explored so far: modern schooling; the reorganization of gendered social space; changing sartorial practices; family laws designating state control over the regulation of marriage, divorce and inheritance; and the reformation of individual moral behaviour. All are practices and institutions that are central to modern state formation - that gain entry for the state in the daily lives of citizens, that orient individual affinities toward the nation, that reproduce the national collective, and that challenge local structures of political authority - that is, not just authority of men over women, but of men over men, or women over men. "Women's rights" are not merely indicative of the state's benevolence toward women, but are constitutive of liberal rule. They are demanded by modernist upper and middle class urban women as well who also seek a realignment of political authority away from tribe, clan or kinship groupings with their attendant commodification of women. ${ }^{6}$

\footnotetext{
${ }^{6}$ For example, Alavi (2001:66-67) describes how the kinship structure of rural Punjab (biraderi) depends upon the ability of panchayat (local council) leaders to control
} 
Not since the 1946 elections had there been such a necessity to mobilize women as voters as there was during the 1970 elections. One woman I interviewed described the efforts of the PPP to mobilize women's votes as leading to a heightened national consciousness among women, further orienting women toward the state:

I think the biggest mobilization of women, politically, in contemporary time was [Zulfiqar Ali] Bhutto. The Pakistan People's Party really sought the women's vote; mobilized women's committees at the mohalla [neighbourhood] level at least, again, I'm talking about in Lahore, in the Punjab experience. So that was I think a very important major factor in politicization of women. Their vote became something that was theirs in the sense that they were being addressed as potential voters ...even if they did in the end vote for [with] the family, women got a sense of their own identity, political identity, I think at that time. (Interview 9)

In the city of Lahore, women from wealthier backgrounds canvassed for the PPP among poorer neighbourhoods, explaining what socialism could offer women, including crèches and washing machines (Mumtaz and Shaheed, 1987), incorporating the domestic into a discourse of production and labour.

Throughout the 1960's more women had been graduating from colleges and universities and entering formal employment. The proportion of women in professions was expanding and in 1973 a "career women's delegation" met with the Prime Minister to request greater access for women to higher levels of government employment. Habib writes that: "Until then, women had been eligible only for accounts services in various departments of government. Soon after the meeting, all services - including the muchcoveted diplomatic service were opened to women" (1984:537).

There were several other reforms for women. A new Constitution was enacted in 1973, which proclaimed that there was to be "no discrimination on the basis of sex alone"

marriages, thereby not only controlling procreation in order to perpetuate the kinship grouping, but additionally ensuring the power of the biraderi leaders over the entire group. 
and enjoined the state to protect women, children, marriage and the family. It also specified the right of employed women to maternity benefits. As it had in the past, APWA continued to lobby the government to protect women from the vagaries of family control and locally articulated patriarchy, and to pursue the enhancement of the authority of the liberal state over the authority claimed by the ulama and Islamists. A member of APWA recalled negotiations with the government regarding the language to include in the constitution:

APWA itself was instrumental in having those clauses included. Because we went in delegation to Islamabad, I was one of them. We went with other NGOs, and we called on all people drafting the constitution. And it was a progressive democratic government that drew up this constitution. So they said to us, 'Well, this is your chance.' I remember the ministers who said so. One was Dr. Mubashir Hassan. He said 'Here's your chance, put in anything you like about equality and women's rights.' So we did. We put in these sort of blanket clauses that would negate anything that discriminates against women. (Interview 14)

Women who were involved in lobbying the government or who directly participated in drafting the constitution did not get everything they wanted however. In particular, their demand for reserved women's seats in national and provincial assemblies that would be directly elected by the female electorate, rather than indirectly elected by assembly members, was rejected.

In 1974, the government passed the Married Women's Property Act, which legally specified that a woman's income was her own, and the Dowry Prohibition Act (Morgan, 1984). In 1976 a Women's Rights Committee was appointed by the government, with nine women among its thirteen members, to make recommendations for improving the social, legal and economic position of women. Since the demise of Basic Democracies there was no uniform system for applying the 1961 Muslim Family Laws Ordinance (MFLO) across the country. The report recommended establishing 
Family Courts to bring the provisions of the MFLO back into effect in a uniform way. The report also recommended that abortion, previously only allowed to save a woman's life, be allowed in cases of "serious danger to her physical and mental health," and recommended some reforms to benefit women in employment, education, legal status and political participation. The report also called on the government to establish nurseries and day care centres, reflecting an emerging politics that blurred distinctions between public and private by acknowledging women as involved in "production" and the public or the state as involved in "reproduction." The recommendations were never acted upon but, like previous commissions and legislation of its sort, were vehemently opposed by the religious parties (Nasr, 1994:183).

As mentioned above, the Bhutto period also saw a continuation of the modernist emphasis on educating women to become housewives, and the importance of individual knowledge of scripture in fashioning the housewife. The PPP's education policy, for example, specified that continuing education would be provided to rural women who may need assistance learning how to become housewives. In a passage reminiscent of Maulana Thanawi's Bihishti Zewar, the policy document promised to provide assistance to: "...rural women seeking to become better housewives by equipping themselves with the arts of reading the Holy Quran and with skills such as sewing, knitting, embroidery, childcare, nutrition, poultry-keeping, etc." (Saigol, 1995:189). The mention of poultrykeeping provided some acknowledgement of women's role in agricultural production. Nevertheless, the statement was odd, Saigol notes, for a government with socialist tendencies: "Women, who do not even get two meals a day, were expected to learn the luxuries of knitting and embroidery" (1995:189). These skills that distinguished middle 
class women and provided a marker of respectability remained an important part of a discursive construction of women as housewives rather than producers. Bhutto's education policy was geared less toward addressing the needs of the poorest citizens and more toward articulating subject positions that further the prospects of liberal state authority in Pakistan's attenuated power structure.

The overall impact on women of reforms made under the PPP government was mixed. Legal guarantees that women's property was their own did not have an impact on the majority of women who own no property. Further, as Shaheed notes, "In Pakistan...on the ground, the operational law is rarely that of the state, particularly in family and gender matters" (1998:144). Despite the economic crisis, jobs opened up for women in the public sector and formally employed women, like men, had greater rights to join unions than they had in the past. A crucial difference for women workers in Pakistan, however, is that a large proportion work under informal contract arrangements, such as piece work, rather than directly for employers (Kazi, 1989; Shaheed, 1989). Labour migration, which expanded substantially during Bhutto's time, helped mitigate high levels of male unemployment, but often led to greater isolation and familial control over the migrant workers' female kin, as I discuss further below. There were no efforts to improve the economic position of the majority of women, and women continued to be seen as primarily the mothers and wives of workers.

Interviews I conducted with women activists who had experienced both the Ziaul-Haq period and the social and political climate of the 1970s during the PPP government, stressed two things about the gendered dynamic of the Bhutto period, which correspond with feminist writing about the period. The first is that although left political 
discourse and organized activity proliferated during this time, there was an absence of gender from this discourse: "I didn't think in terms of just women at that point. [At] That time it was the awam - the people. And so it was poor against rich, and the oppressed and you know, it was that kind of mind set" (Interview 5). Another woman emphasized that among the left groups that were proliferating among students and urban professionals at that time, women were present but "they were not really decision-makers, they were there, they sat on the committees and they were assigned work to do, but ...it was the class issues that were paramount" (Interview 9).

The second aspect of the Bhutto period stressed in interviews was the growing "visibility" or presence of women in the public sphere. In Pakistan, as well as surrounding countries, public space was becoming feminized with the emergence of many small women's groups, the appearance of women on television, and the visibility of a number of women in high profile positions. Unlike Ayub Khan's wife who observed purdah, Bhutto's wife, Nusrat Bhutto, was prominent in international circles, leading Pakistan's involvement in the1975 United Nations International Women's Year (Jalal, 1991). This period also saw the first women occupying senior government positions, including the Governor of Sindh, and the Deputy Speaker of the National Assembly. Reforms to the civil service allowed women to enter all branches of the civil service, and women began to be hired in service industry jobs that were previously male preserves such as bank tellers and ticket agents. The significance of allowing women to be posted abroad in government service becomes clearer under Zia-ul-Haq who, along with his supporters, reacted strongly against this variant of reform to the norms of purdah. The end result is what many describe as a growing "visibility" of women: "There was more 
liberalism towards women after the 1975 Mexico conference on women. We were all sort of going out into the public sphere, establishing businesses, going into jobs. We were more visible" (Interview 1).

Both the growing public visibility of middle and upper class women and the absence of gender from "progressive" political discourse at the time may be linked to an underlying politics of sameness which began to obscure the boundaries between male and female, along with any discussion of the particular disadvantages faced by women. This can be read in gendered policies of the time permitting the entry of women into formerly exclusively male arenas such as the diplomatic service. Rouse also observes a "far greater equalization of men and women in public spaces and a greater rapprochement of the sexes" reflected in Bhutto's own clothing practices (1997:155). Along with his antiimperialist rhetoric, Bhutto took to wearing regional and local clothing styles, depending on the part of the country he was in, but his politics of clothing was focused on men's dress, not women's. Meanwhile, middle and upper class women were wearing western styles such as jeans in urban areas:

During the Bhutto era, it's true that...you could openly wear jeans. During the hippie era there were many women wearing torn jeans and patched jeans...I used to go to college all the four years in jeans, and in pants, and women were not taking dupatta. ${ }^{7}$ So the Bhutto era was in that sense very liberal at least in the urban cities among classes like ours." (Interview 1)

In stark contrast, during Zia-ul-Haq's rule, the public discourse was very much about gender, as there was a push by an Islamizing military regime to separate and demarcate

\footnotetext{
${ }^{7}$ A long scarf or cloth worn draped over the shoulders. In Pakistan, while men often wear western dress in the cities, women predominantly wear the shalwar kameez, and nearly always with a dupatta.
} 
genders spatially and sartorially. ${ }^{8}$

During the 1970s, women's politics and activism began to take on a different character. The radicalism of the 1960s had shaped a number of activists, who continued to work through trade unions, student groups, and community organizations, spreading organized political activity to a broader class base. A number of new women's organizations were formed during this period, taking up new issues such as women in development, women's labour market status, discriminatory legislation, and women's position in government. For the first time, many women's groups were prepared to criticize the government openly. Women's organizations began to form with research functions as well, such as Shirkat-Gah, which later played a central role in the formation of the Women's Action Forum during Zia-ul-Haq's rule.

Yet, while there were strong challenges to purdah norms, such as unveiled women on television and female civil servants traveling abroad, there were other changes that led to a strengthening of purdah at this time. Migration to cities often led to greater confinement of women: "In urban areas the social organization of the environment is such that all spaces outside the home automatically become public" (Shaheed, 1989:20). In contrast, private space for many village women may extend to fields, communal wells and washing areas. Outside the cities, stricter forms of purdah involving confinement indoors and wearing of the burqa are observed mostly among the relatively small category of the "rural rich." Among poorer families, when there is an increase in a family's income level, there is a greater pressure to increase purdah restrictions on women in the family as a marker of status and respectability. Purdah is practiced most

\footnotetext{
${ }^{8}$ In another blurring of gendered practice, some of the women I interviewed also wore their hair cut short, which suddenly became problematic during Zia-ul-Haq's time when they describe feeling social pressure to account for their hair length.
} 
strongly among the lower middle class who seek to distinguish themselves from the poorest families (Shaheed, 1989). Among families of labour migrants to the Persian Gulf states, there was a heightening of purdah restrictions on women resulting from the increase in family income, greater control by male relatives, and the heightened need for the outward appearance of propriety within families in which the men are absent (Rouse, 1997). Cautionary tales circulated about the changes taking place in gendered space during this period; Jalal writes that "Horror stories of women with meagre resources living outside the protected walls of the traditional Muslim family being forced into prostitution in the oil-rich Gulf states were among the most widely read news items of the time" (1991:100).

\section{The Military and Islam}

Bhutto's period in power saw a growth in the strength of the nexus between the military and Islam. A militarized nationalism emphasizing Islam provided a means of countering the class and regional conflicts that had become so strong under Ayub Khan (Saigol, 1995:176). Bhutto's assertion of an overriding Muslim identity, in conjunction with his emphasis on resolving domestic conflicts militarily, presaged the strong Islamization and militarization of Pakistan under Zia-ul-Haq.

\section{Bhutto's Islamization}

Though not part of the 1970 PPP election manifesto, Bhutto talked about "Islamic Socialism" while campaigning. The phrase "Islamic socialism" was also used by politicians in the past, including Jinnah and Liaquat Ali Khan, to emphasize general values of egalitarianism, opposition to exploitation, and anti-colonialism or antiimperialism (Syed, 1992:67). During the 1970 campaign, the ulama united to condemn 
socialism as the biggest threat to Pakistan and proponents of socialism as enemies of Islam, while supporters of the PPP linked this pronouncement to the cold war rhetoric of imperialist powers, and countercharged that the ulama pronouncement against socialism was an "American fatwa" (Syed, 1992: 71). Nevertheless, once in power, Bhutto himself used Islam to marginalize the left within the People's Party, and incorporated Islam strongly into nationalist discourse.

While Bhutto's Islamization did not have a strongly gendered component, he turned other key demands of the Islamic parties into state policy. The 1973 Constitution proclaimed that sovereignty rests with God, overturning the secular tone of the country's first constitution, and granting constitutional language demanded by the ulama and Jamaat-i-Islami since the formation of the country. The document further stated that Islam was the "state religion," that laws were to be brought into conformity with Islam, and that schools were to teach Islamic studies and the Quran. In 1975, months of antiAhmedi riots took place, again led by the Jamaat-i-Islami and its student wing, the IJT. In another clear change of course from that set by Pakistan's early jurists and legislators, Bhutto led the National Assembly in voting to declare Ahmedis non-Muslims. The education policy of 1972 called for the extension of Islamiyat (Islamic Studies) to higher grade levels and the recitation of the Quran on television "to saturate the air with the message of God and further forge the bond of national cohesion among the Muslims in different parts of the country" (Government of Pakistan, 1972, quoted in Saigol, 1995:176-77). During his last days in power, as he felt a growing threat from the political opposition united under the slogan of Nizam-i-Mustapha (rule of the Prophet), Bhutto banned gambling, night clubs, and public consumption of alcohol, and proclaimed Friday 
to be the weekly holiday instead of Sunday.

Pakistanis were increasingly encouraged to see themselves as belonging to a Muslim or Islamic world, cutting the linkages with their Indian or South Asian heritage (Saigol, 1995:84; Shaheed, 1998:145-46). ${ }^{9}$ Bhutto took several measures that promoted the idea of an international Muslim collectivity. In 1974, Pakistan convened an Islamic Summit of the leaders of Muslim nations - an assertion of commonality that glossed over the atrocities committed among Muslims three years earlier in Bangladesh, not to mention the discord among some of the other leaders. ${ }^{10} \mathrm{He}$ sponsored an international conference on the life of the Prophet Muhammad, and invited the imams of the mosques in Mecca and Medina to visit Pakistan. Bhutto's foreign policy de-emphasized relations with the United States, took Pakistan out of the British Commonwealth, and sought stronger relations with China and oil-rich Muslim countries, particularly Saudi Arabia, Libya and Iran. Pursuing closer linkages with wealthy Muslim countries served military and economic purposes. It facilitated the migration of thousands of Pakistani workers to the Persian Gulf oil kingdoms. The relationship with Saudi Arabia was particularly important. Saudi Arabia provided oil grants and funding for Pakistan's military in return for military training and assistance from Pakistan (Cohen, 2004:122). In 1976, one quarter of total Saudi aid went to Pakistan (Tahir-Kheli, 1982:158).

\section{Bhutto's Militarism}

Bhutto placed great emphasis on refurbishing and strengthening the military. The

\footnotetext{
${ }^{9}$ This reorientation of Pakistan's spatial location in the world was furthered by Zia-ulHaq in myriad ways, but perhaps most blatantly when he closed the Department of South Asian Studies at Punjab University.

${ }^{10}$ Rouse observes: "His invitation to Boumedienne and to the Shah of Iran were taken as a direct insult by the House of Saud" (2004:136).
} 
1971 loss to East Pakistan and India challenged the nationalist ideology of the martial races and the widely held notion that one Punjabi or Pashtun soldier was equivalent to several from the "non-martial races" of the subcontinent (Cohen, 2004:103). It was the military's defeat that was demoralizing, not their conduct of the war. Meanwhile, in West Pakistan there was near universal silence surrounding the violence perpetrated against East Pakistan (Said Khan, 1995).

The realization of Pakistan's insurmountable military weakness in relation to India - despite the enormous state expenditure on, and foreign subsidies to, the military may have led to Bhutto's initiation of a program to build nuclear weapons in 1972, as well as his increase in expenditure on the military notwithstanding the country's economic crisis. However, consistent with Bhutto's other efforts to divert some power away from the military leadership, the nuclear program remained under civilian control until Zia-ul-Haq came to power. The 1972 Education Policy also appears to reflect an emphasis on "redeeming the military's image and creating respect for it among the citizenry" (Saigol, 1995:199). Comparing the curriculum and pedagogical approaches outlined in the Education Policy documents of Ayub Khan, Zulfiqar Ali Bhutto and Ziaul-Haq, Saigol found that Bhutto's policy in particular emphasized military training and weapons training for all students and called for a National Service Corps in which all young men would be expected to serve.

Educational policies emphasizing the citizen soldier appear to have a continuity with strategic thinking within the military itself at the time. As a result of the military alliance struck with the United States during the 1950s, Pakistan's military leadership received training in the United States or from Americans from the mid-1950s until 
relations began to sour in $1965 .{ }^{11}$ Cohen writes that "Influenced by the United States, Pakistan undertook a detailed study of guerrilla warfare and people's war" (2004:104). This included the use of "irregular forces" and/or "low intensity conflict," evident in Pakistan's military strategy in Kashmir for decades, in East Pakistan in 1971, and in Afghanistan since 1980. This was not a policy that was devised by Bhutto; however, he supported these tactics in Kashmir and East Pakistan and his education policy seems to toy with the idea, studied by the military leadership, of "developing a people's army as a second line of defense" (Cohen, 2004:104). ${ }^{12}$ These developments during the 1970s were a harbinger of things to come. Writing in the 1990s, Saigol notes: "The extent of the militarisation of Pakistani education and society can be gauged from the fact that there is a proliferation of arms among the country's youth and thousands of university students own and carry guns" (1995:200).

During the PPP government's tenure, there was much civil unrest, including huge strikes and labour disturbances, anti-Ahmedi riots, language riots and regional uprisings in various parts of the country. Bhutto relied heavily on military solutions to these various conflicts within Pakistan. The army was called upon to put down protests in different locations throughout the country on seven occasions between 1972 and 1977 (Rizvi, 2000:222). This included a full-scale military operation launched in Baluchistan, which lasted from 1973-1977. In 1973, Bhutto dismissed the Governor and the Chief Minister of Baluchistan, charging them with anti-state activities such as maintaining

${ }^{11}$ Cohen (2004) refers to this as the "American generation" in the Pakistan military. Prior generations were trained by the British, and subsequent generations in Pakistan.

${ }^{12}$ Cohen suggests that the United States' interest was primarily in suppressing guerrilla warfare. However, throughout the Cold War, there are also examples of American efforts to foster guerrilla warfare, including its joint efforts with Pakistan in Afghanistan during the 1980s. Today, Pakistan's military is engaged in a confused process of simultaneously promoting and fighting Islamist groups trained in these techniques. 
private militias and sabotaging infrastructure and public works. This led to the resignation of the governments in Baluchistan and NWFP, both of which were led by a coalition of the Jamaat-Ulama-i-Islam (JUI) and the National Awami Party (NAP). The ensuing military action led to the killing of several thousand Baluchis and forced thousands to flee into Afghanistan (Cohen, 2004:220; Siddiqa, 2007:81).

One of the major ways in which Bhutto left a dual legacy of Islamization and militarization in Pakistan was through the increased funding and role given to military intelligence. Bhutto strengthened the intelligence body within the military, the InterServices Intelligence (ISI), which went on to become deeply involved in the training and funding of Islamist groups in Pakistan and neighbouring countries. The ISI had become prominent during the 1971 war when there were concerns about the loyalties of Bengali officers within the civilian Intelligence Bureau, and the ISI began to recruit Islamist groups for "counterinsurgency operations" in East Pakistan (Cohen, 2004:100). Bhutto increased funding to the ISI and continued using it to gather intelligence on domestic threats and on the aspirations of the new Afghan leader, Sardar Daud Khan, for a united Pashtun homeland encompassing Pakistan's NWFP. ${ }^{13}$

Bhutto is often identified as the leader who began the process of state-sponsored Islamization in Pakistan. This is true in that discourse began to change and linkages were formed that would support a more thorough change in Pakistani society in the coming years. Bhutto used Islam as a form of nationalism, and rhetorical anti-imperialism. As such, he did not envisage the Islamization of all spheres of society called for by the Jamaat-i-Islami, yet in helping to shift political discourse toward more explicit references

\footnotetext{
${ }^{13}$ Daud deposed his cousin, King Zahir Shah, in 1973. He was later killed in a coup by the communist People's Democratic Party of Afghanistan in 1978.
} 
to Islamic morality and conduct, he laid some of the groundwork for a more radical Islamization yet to come. He also strengthened the military and the militarization of government. Though there is not space to detail this more fully here, Bhutto's period in power is an interesting staging point in the history of the confluence of militarization and religious authority that has become prevalent in contemporary times in Pakistan and elsewhere, evident in religious, theological, or crusading forms of government and war.

\section{Political Opposition}

\section{The Jamaat-i-Islami}

The Jamaat-i-Islami received less than five percent of the vote in the 1970 elections (Ahmad, 1983:122). During the Bhutto period, those opposed to his nationalization policies, socialist rhetoric or Sindhi linguistic and ethnic identity, often turned to the Jamaat-i-Islami as an anti-socialist force and a defender of the notion of the "true," devout, Urdu-speaking Muslim. Such groups included industrialists, urban middle classes, and the Muhajir community in Karachi and elsewhere in Sindh. They also included wealthy Persian Gulf monarchs who began to fund the Jamaat-i-Islami during the 1970s. Previously the party had relied on voluntary contributions, income from members, and proceeds from the sale of its books and writings. The Jamaat-i-Islami gained much strength internationally, and influence with the Pakistan government, through its links with Saudi Arabia (Nasr, 1994:60).

While the Jamaat-i-Islami did poorly in the 1970 elections, the IJT was doing well in university elections. The PPP's student wing, the People's Student Federation, lost to the IJT in a number of elections in Punjab and in Karachi. Ahmad writes: "During his five-year rule, neither Prime Minister Bhutto nor any of his cabinet ministers could visit 
any major campus in the country because of the IJT's complete control" (1991:493). Though the IJT, like the Jamaat-i-Islami, had a women's wing, little has been written on their activities since they are not "public" and the organization's activities are highly gender segregated. Rather than openly attempting to recruit women as autonomous, individuated subjects, the IJT attempted to gain control over female students by making contacts with their families (Nasr, 1992:70-72).

While the Jamaat-i-Islami had a small following within the general population, its constituency within the military was much larger. No other political party was able to function with cells and proselytizing activities within the military (Ahmad, 1983:123). The 1971 war had forged a close relationship between the Jamaat-i-Islami and the army, leading the former clearly to understand a military coup as its best route to power. In fact it put such a request to the Chief of Army Staff in 1973 (Rizvi, 2000:221). In addition to its position within the armed forces, the strength of the Jamaat-i-Islami came largely by means of its rhetorical power built through control of educational institutions and the vernacular press. The Jamaat-i-Islami operated within the same institutional and organizational structures as liberal political forces: parliaments and other state institutions, trade unions and professional organizations, universities, and the press (Ahmad, 1991:485). Throughout the 1970s, Jamaat-affiliated student, labour, peasant and professional unions and organizations were established to counter left unions. The Jamaat-i-Islami and IJT had traditionally not recruited in mosques and madrasahs, prevented by the ulama from doing so; although during the 1970s the Jamaat-i-Islami began to establish its own madrasahs (Ahmad, 1991:493). Few leaders within the Jamaati-Islami had formal religious training: a 1975 survey of the party's leadership at different 
levels of the organization found that most were owners of small businesses or professionals such as lawyers, doctors, accountants or journalists (Ahmad, 1991:494-95). The party put forth a moral critique of wealthy classes, and elites within the bureaucracy, while dismissing the militancy of the working classes and the threat it posed to private property. While other political parties opposed to the PPP attracted support from a similar base among merchants, traders and the urban middle class, the Jamaat-i-Islami was unique in that it had substantial funding from abroad to promote its message and a privileged place within the military.

\section{The Pakistan National Alliance (PNA)}

National elections were held in March of 1977. Opposition parties united in a coalition to challenge the PPP, called the Pakistan National Alliance (PNA). The PNA included the three main religious parties, the Jamaat-i-Islami, the Jamiat-ul-Ulama-iPakistan (JUP), and the Jamiat-ul-Ulama-i-Islam (JUI)), as well as the conservative Muslim League. It also included secular parties with a variety of political philosophies. Key among these were the National Democratic Party (NDP) and the Tehrik-i-Istaqlal. The former was a reorganized version of the National Awami Party, a party with a leftist base and a strong following in Baluchistan and NWFP, which was banned by Bhutto in 1975. The latter was created in the late 1960s by Asghar Khan, a former military officer. It had a "liberal modernist" outlook and drew support from some components of the Karachi business and merchant class, the armed forces, and some landlords (Ahmad, 1983:140-141).

The PNA drew support from private industrialists, merchants and small traders, 
lower level bureaucrats, landlords in Baluchistan and NWFP, ${ }^{14}$ and sections of the army who were sympathetic to the Nizam-i-Mustapha rallying cry (Talbot, 1998: 244). Noman (1988) details a number of sources of conflict between the PPP government and urban middle classes, including the 1976 nationalization of agro-processing industries which, unlike the earlier nationalizations, affected smaller entrepreneurs; the nationalization of private schools which, in the absence of a concomitant increase in educational funding, resulted in a decline in the quality of education for middle class children; and the inflation-induced decline in real incomes among those who, unlike public servants and factory workers, were not the beneficiaries of government legislated wage increases.

The PNA's platform emphasized reducing the state's role in the regulation of the economy, calling for the return of the agro-processing industries to their owners, and the denationalization of all except "basic industries" (Dawn Review, February 13, 1977). The PNA promised protection for private educational institutions, and called for the imposition of shariat. The PNA Manifesto also promised to close family planning centres and ban "adultery, horse racing, gambling, obscenity, nudity, child trafficking, pornographic books, films and advertisements" (Dawn, February 10, 1977). It also called for separate women's educational institutions, including universities.

While campaigning, Bhutto accused the PNA of representing "agents of capitalism" and claimed that the PPP stood for the rights of women and "the workers, the peasants and the poor classes" (Dawn, March 3, 1977). Politicians in the PPP accused the PNA of seeking to return women to the "four walls of the house," to which the SecretaryGeneral of the PNA, Rafiq Ahmad Bajwa, responded that the PNA "only wanted to

\footnotetext{
${ }^{14}$ Landlords in the NWFP and Baluchistan, who supported parties other than the PPP, were not part of Bhutto's patronage network and were more affected by land reforms than those in Punjab and Sindh (Noman, 1988:94).
} 
convey to women the message of Allah and his Prophet" (Dawn, March 3, 1977)

The PPP's election platform on women can be read as a succinct re-statement of the liberal modernist perspective, emphasizing the need to extend citizenship rights to women, and the need to reform customs, the family, purdah and the gendered organization of social space. The chapter on women in the 1977 PPP manifesto stated:

We have striven in accordance with the dictate of Islam, to give women their rightful place in society, which has been denied them in the past. In pursuit of this policy, the historic Declaration on the Rights of Women was announced in October 1976.

We will implement the provisions of the Declaration, the principle [sic] features which are aimed at-

Taking appropriate measures against discriminatory and prejudicial customs and practices which are contrary to the injunctions of Islam, violate the Constitution and cause enormous hardship to the poor.

Ensuring women their rights according to personal and family laws.

Ensuring women their social, legal, education, health and economic rights. Giving women representation in delegations going abroad, in official bodies and associating them in the Government's policy-making and planning

(Pakistan People's Party, 1977, reprinted in Dawn Review, January 26, 1977).

Once again, the explicit reference to "giving women representation in [government] delegations going abroad" was at the forefront of rights to be accorded to women. Women's representation in foreign delegations was far from the foremost issue facing women in Pakistan. However, the issue of women going abroad became a symbolic one that the PPP promoted as strongly as the PNA opposed. This was in part because other reforms that the PPP had spoken about, such as family courts or child care programs, had not been implemented. In this context, women's participation in foreign delegations became a highly visible action that came to represent a conflict over purdah norms, as well as over a growing, and increasingly feminized, state sector, and over a gender order that diminished distinctions between masculine and feminine.

A renewed criticism of elites emerged, one that alleged they were westernized, 
spoke English, ${ }^{15}$ engaged in decadent behaviours such as drinking alcohol and lavish spending, and dishonoured women by forcing them into public arenas. In the PNA discourse, the worsening economy was linked to immoral behaviour of the country's leaders. The head of the JUP, Maulana Shah Ahmad Noorani, declared that for five years the country had "suffered from obscenity, immorality, corruption, luxury living and price hike" (Dawn Review, February 1, 1977). The PNA promised to return prices to their 1970 level through "introducing simple ways of living and discarding luxuries" (Dawn, March 3, 1977). ${ }^{16}$ The campaign was portrayed repeatedly in politicians' comments as a battle between socialism and Islam (Dawn, March 5, 1977). Despite his Islamization measures, and his nearly constant references to Islam, Bhutto was accused of being against Islam and portrayed as secular and westernized (Nasr, 1994:172).

The PPP won 155 of 200 seats in the national election. Claiming the election was rigged, the PNA immediately announced a nationwide strike and a boycott of provincial elections that were to be held a few days after the national vote. With its support among small traders and merchants, the PNA was effective at closing businesses during strikes, and parties within the PNA - in particular the Jamaat-i-Islami and IJT - were very experienced with urban rioting. In April, martial law was declared in Lahore, Karachi and Hyderabad. In response to street protests, Bhutto announced Islamization measures such as banning alcohol, but such measures could not have been expected to appease the opposition. The Jamaat-i-Islami had been looking for a military coup since the day the

\footnotetext{
${ }^{15}$ While Urdu was the national language, the elites still functioned very much in English and went to private English-medium schools. Middle cases went to government Urdumedium schools, and Urdu-medium education was, and continues to be, looked down upon by wealthier classes as second rate, causing resentments within middle classes that Zia-ul-Haq later capitalized on with his emphasis on Urdu.

${ }^{16}$ The "simple living" discourse became even more prevalent under Zia-ul-Haq.
} 
PPP became the government, and some of the larger parties within the PNA - the NDP and Tehrik-i-Istaqlal - were secular in orientation with demands respectively focused on greater regional autonomy and denationalization of industry. Protests continued for weeks while the government and opposition negotiated what to do about the election results. On July $5^{\text {th }}$, Chief of Army Staff, General Zia-ul-Haq, dismissed the government, dissolved the National Assembly and suspended the constitution of Pakistan. Zia-ul-Haq declared martial law under the pretext of restoring law and order and promised new elections within ninety days - elections that never took place.

While some writers speculate that Zia-ul-Haq originally planned to hold elections until he realized the extent of Bhutto's continued popularity (Talbot, 1998:243), others saw that a very different political project was underway. In March of 1977, Aijaz Ahmad wrote:

...despite Mr. Bhutto's juggling with the command structure and his many rewards to Army and Police, there will still be a coup...it is likely to adopt a populist and puritanical stance....In the name of an 'Islamic way of life', it will impose a medieval labor code in the factories; will weed out all remnants of intellectual life in the universities; and will seek to reverse all the marginal gains the peasantry has made during struggles of the past five years... and terror under such a regime, if it comes about, is likely to reach a scale heretofore unknown and unimagined in our body politic" (reprinted in Ahmad, 1983).

The liberal project of Muslim nationalism was being eclipsed in favour of a very different project of rule in Pakistan, one that was based on the destruction of the left, an attack on the notion of a redistributive state, redemption of the sanctity of private property and a very different gender order.

\section{Conclusion}

When Pakistan's first national elections took place in 1970, those who had 
attempted to shape the nature of the country's polity up until that point - foreign and national experts and bureaucrats, the Muslim League, Islamists and Islamic parties - were uniformly marginalized in favour of parties advocating popular demands for regional autonomy and socialism. During the first three years of the PPP government, a number of measures were taken, including nationalizations, the extension of labour laws, and the indexing of wages to inflation. State policy not only attempted to further family law and respond to the demands of social feminism, but also demonstrated aspects of "state feminism." Islamism came to the fore at this time as an oppositional politics that offered a number of benefits for those opposing the PPP: it critiqued socialism; it offered a strong anti-state stance; and it questioned the moral behaviour of wealthy elites, working classes, and the poor alike - essentially the support base of the PPP. As I argue in the next chapter, Islamist discourse also provided a means to dismantle social government. 


\section{Chanter Five \\ Islamization under Zia-ul-Haq, Part 1: Deconstructing the Nation, 1977-1988}

\section{Introduction}

During his first address to the nation on July 5, 1977, General Zia-ul-Haq proclaimed that his "sole aim" was to hold free and fair elections in October of that year. Tellingly, however, his speech also contained the statement: "I consider the introduction of Islamic System as an essential prerequisite for the country." Zia-ul-Haq spent the next eight years trying to forestall national elections in favour of various arrangements he considered to be more Islamic than parliaments. In 1985, Zia-ul-Haq became President of Pakistan after amending the constitution to greatly expand the powers of the President, and he allowed elections to take place on a strictly non-party basis. Martial law was finally lifted in December of 1985. Zia-ul-Haq maintained control over the National Assembly and dismissed it in May of 1988. In August of 1988 Zia-ul-Haq died in an airplane crash and national elections in November, allowing political parties, saw the PPP return to power led by Zulfiqar Ali Bhutto's daughter, Benazir Bhutto.

Zia-ul-Haq situated his government within the language, demands and social base of the anti-PPP, Pakistan National Alliance (PNA). He transformed the PNA's call for Nizam-e-Mustapha (system or rule of the Prophet) into an announced plan to establish "Nizam-e-Islam" (system or rule of Islam) in Pakistan. He also set about to accomplish the other concrete demand of the PNA to protect private property. He adopted the PNA's discourse critiquing "westernized" Pakistanis, as well as their demands to end a number of vague and disparate social ills (for example, bribery, smuggling, black-marketeering, obscenity, nudity), evoking a sense of a social order plagued by problems resulting from 
individual actions and immorality and in need of what Zia-ul-Haq often referred to as "cleansing" or "purifying."

I argue that Zia-ul-Haq's project of Islamization was not a heightened form of nationalism, or even "religious nationalism" as is sometimes suggested (Verkaaik, 2004:24). Zia-ul-Haq often referred to "the nation" in his Islamization efforts, meaning that "the nation" was founded on the basis of Islam, and therefore, any Muslim living within the administrative unit of Pakistan must embrace the "Ideology of Pakistan" which is (an Islamist version of) Islam. The Jamaat-i-Islami also used the term in this sense, as well as to argue against ever-present "sub-national" demands for regional autonomy (Bengali, Baluchi, Sindhi or Pashtun) with their (secular) claims to unique linguistic, historical, geographical or cultural coherences. However, despite his references to "the nation," Zia-ul-Haq's regime was characterized by attempts to dismantle practices, institutions, techniques, and forms of self that reflect, create, enact or otherwise give life to the nation. I devote the next chapter to addressing how an attack on social feminism and middle class women was an essential component of this project of dismantling the nation. In this chapter I provide a more general discussion of Zia-ul-Haq's approach to deconstructing the nation, pursued through a combination of prohibiting, transforming or undermining certain institutions and forms of practice that create national identifications, while creating or promoting alternate or parallel ones that fostered both local identifications, as well as a form of Muslim subjectivity situated within a global geography. Instead of parliaments, public schools, secular courts, and the arts, for example, Zia-ul-Haq favoured a localized politics of mosque and mohalla 
(neighbourhood), mosque schools ${ }^{1}$ and madrasahs, military courts, shariat courts, and the public performance of piety. The secular concept of the nation, the abstraction of society, and the practice of social government were all undermined in the process.

\section{Nizam-i-Islam versus Parliamentary Politics}

Zia-ul-Haq spoke often against secularism, claiming that "According to Islamic concepts sovereignty vests in God. There is no concept of sovereignty of man."2 In consonance with his view that sovereignty rests in God, Zia-ul-Haq had no use for political parties, political activities such as meetings, demonstrations or speeches, or national representative political institutions. Zia-ul-Haq frequently complained that political parties detract from a focus on performing one's duties under Islam, and instead engage in "political wrangling" and promote "regional feelings and prejudices." 3 He felt that beyond enforcing Islam and overseeing the economy, there were no legitimate issues for national debate; and he particularly despised those groups in Pakistan that were most identified with secularism, and social government, namely those with some elements of socialism in their platforms. The latter included various Marxist groups, the Communist Party, the Baluchistan-based National Democratic Party (NDP), ${ }^{4}$ trade unionists and, above all, the PPP which was brutally dealt with under Zia-ul-Haq.

A clear sign that Zia-ul-Haq intended to contravene fundamental principles of national citizenship was his announced threat of "exemplary punishments" for those engaging in political activities in his first address to the nation. This was followed over the course of the next months and years with floggings and hangings. The main target

\footnotetext{
${ }^{1}$ Primary schools located in mosques.

${ }^{2}$ General Zia-ul-Haq, Address to Federal Council, February 5, 1983.

${ }^{3}$ General Zia-ul-Haq, Address to the Nation, July 27, 1977.

${ }^{4}$ Formerly the ANP or Awami National Party.
} 
was the PPP and tens of thousands of members of the PPP became political prisoners over the next few years. Zulfiqar Ali Bhutto was executed in 1979 and his family members imprisoned, put under house arrest or forced into exile. Trade union activists were similarly targeted. When martial law was declared, political activities were banned and restrictions were placed on trade unions with harsh punishments for those breaking these restrictions. Journalists were also closely monitored and jailed or flogged for questioning the regime. In March of 1978, when an Iranian journalist asked if he intended to suppress leftists before holding elections, Zia-ul-Haq responded "I have no dispute on this. I am a Rightist...the sooner the Leftists wake up and come to the middle of the road, the better it would be for them because I have now started tightening my grip."

In Zia-ul-Haq's particular conception of history, Pakistan was created on the basis of Islam and therefore the polity must be modeled on an Islamic system. When Zia-ulHaq spoke about the "ideology of Pakistan" being Islam, he was closely following Maududi's language and theorization of Islam as an ideological movement. What an Islamic system was, Zia-ul-Haq devised as time progressed. In 1978, Zia-ul-Haq brought remaining members of the PNA, namely the Pakistan Muslim League, the Jamaat-iIslami, and the Jamaat-Ulama-i-Islam (JUI), into a cabinet that was to oversee elections in November of $1979 .{ }^{6}$ The Jamaat-i-Islami played a key role in shaping the early policies of the government:

Not only were Jama'at leaders placed in charge of sensitive cabinet portfolios and invited to serve on such prominent state-sponsored organs as the Council of Islamic Ideology, but a number of pro-Jama'at thinkers, writers and journalists were inducted into the inner circle of Zia's advisors with a view to laying the foundations for a viable machinery for an Islamic state (Nasr, 1993:267).

${ }^{5}$ General Zia-ul-Haq, Interviews to Foreign Media, March 27, 1978.

${ }^{6}$ By 1978, several parties had left the PNA, including the NDP, Tehrik-i-Istaqlal and Jamaat-Ulama-i-Pakistan. 
Zia-ul-Haq frequently suggested that a western-style system of elections was not appropriate for Pakistan, and expressed a preference for an amir (chief) with a council of advisors selected on the basis of moral character rather than party affiliations or competition. He claimed that Muslims were not suited to a parliamentary system of government, and suggested that instead of voting for national representatives people could bring their concerns directly to him.

Local elections were held in September of 1979 and individuals known to be affiliated with the PPP dominated the election results (Jalal, 1990:322). Zia-ul-Haq then cancelled the November national and provincial elections and banned political parties outright. In March of 1981, Zia-ul-Haq set up an Advisory Council (Majlis-i-Shoora), to which he appointed loyal members of local or provincial councils and representatives from powerful families. He fashioned himself as an amir and retained for himself most power to legislate and to amend the constitution. He cautioned appointees against party politics however, suggesting that in representing interests beyond themselves they would not be "speaking their minds" or being honest:

There is no party in this House. By the grace of God I have no party yet. Therefore I and the nation rightly expect that you will speak your mind while addressing the House. If you accept constraints like tribal considerations then you are not discharging your duties in an honest way nor are you assisting me in any manner. $^{7}$

In this formulation members were not to represent constituent, clan or tribe. One cannot claim a purity of intention by locating oneself within the corrupt and illegitimate sphere of the tribal/social.

\footnotetext{
${ }^{7}$ General Zia-ul-Haq, Address to Fifth Session of Federal Council, February 5, 1983.
} 
In 1981, the PPP joined with other parties opposing the dictatorship to form the Movement for the Restoration of Democracy (MRD) in order to apply increased pressure for elections and an end to martial law. It was also at this time that the Women's Action Forum (WAF) came into being to protest various Islamization measures and a growing push toward gender segregation. However, the greater pressure to allow elections and national political activity may have come from landed elites and other local political authorities that were accustomed to collaborating with various administrations to augment their power.

After experimenting with the Advisory Council, Zia-ul-Haq devised a type of Islamic presidential system of government under which elections were permitted at the national level. His first order of business was to hold a referendum on his rule in 1984 . The outcome was officially proclaimed to be a near unanimous endorsement, thereby "electing" Zia-ul-Haq President for the next five years. ${ }^{8}$ Zia-ul-Haq then proceeded to allow elections to take place in 1985 on a strictly non-party basis. During the campaign, public meetings, speeches and processions were not allowed. To increase their profile, candidates spent enormous amounts of money on advertising, and the election was marked by "the lack of national themes coupled with the absence of nationwide political

\footnotetext{
${ }^{8}$ Turn-out was reported at around 30 percent by unofficial sources (Richter, 1985). Political parties in Pakistan are associated with symbols that appear on elections ballots for non-literate voters. The wording of the referendum question, for those able to read or make sense of it, gave a negative vote connotations of treason, blasphemy and antidemocratic sentiment:

"Whether the people of Pakistan endorse the process initiated by General Mohammad Zia-ul-Haq, the President of Pakistan, to bring the laws of Pakistan in conformity with the injunctions of Islam as laid down in the Holy Quran and Sunnah of the Holy Prophet (peace be upon him) and for the preservation of Ideology of Pakistan, for the continuation and consolidation of that process for the smooth and orderly transfer of power to the elected representatives of the people."
} 
alignments" (Rizvi, 1986:1070). In their place, political discourse focused on the candidate's observance of Islam and the promise to provide local services and infrastructure. National and foreign policy issues were replaced, for example, by promises to install street lights and assurances that the candidate prayed five times a day. The 1985 elections were boycotted by all parties on the left. The resulting national and provincial assemblies were composed of a mixture of landed, commercial and industrial elites, tribal leaders and religious politicians. Zia-ul-Haq appointed Mohammad Khan Junejo as Prime Minister and assigned him the task of creating a governing political party within the assembly, to be named the Pakistan Muslim League. Despite the connotations of continuity in the party's designated name, members were attracted to the party not through a shared affinity in policy platforms, but through financial recompense, reflecting an increasing monetization of politics that was also evident in the 1985 partyless elections (Jalal, 1995:105-107). Zia-ul-Haq cautioned National Assembly members that they were not to contradict his authority in any way; in an address to the nation on March 2, 1985 he stated: "To my mind, there is no concept of the treasury benches or the opposition in an Islamic system of government." When the assembly indeed proved too prone to contradicting his authority, Zia-ul-Haq dismissed it in May of 1988.

While over time Zia-ul-Haq was forced to allow some political activity at the national level, his preference was for a dictatorship enforced through local Islamic figures and local committees and institutions. Local elections were allowed during martial law in 1979 and 1983. For Zia-ul-Haq, local political bodies had a legitimate function, which was organizing and carrying out of the duties of Islam and the policing of morality, as 
well as the administration of local infrastructure and services. Central to his model of local governance were the Zakat and Ushr Committees set up to administer the new Islamic taxes he introduced in 1980 . These are discussed further in the next section. The groups Zia-ul-Haq thanked for supporting him during his 1984 referendum provide an indication of his preferred political institutions and actors: Nazeem-e-Salat (prayer monitors), ${ }^{9}$ members of Zakat and Ushr Committees, imams of mosques and other religious figures, and local councillors. ${ }^{10}$ Politics under Zia-ul-Haq became localized, while national level politics were marginalized. Even the Jamaat-i-Islami, as a political party active in the field of national politics, felt itself losing ground in this context as the regime extended patronage to the more sectarian groups of ulama associated predominantly with a localized political field of mosque and madrasah (Nasr, 1993). The Jamaat-i-Islami also found the military's understanding of democratic institutions lacking. When a Senator, Brigadier M. Hayat Khan, complained during Senate proceedings that women from the Jamaat-i-Islami were trying to "blackmail" politicians by demonstrating outside the parliament, fellow Senator and leader of the Jamaat-iIslami, Qazi Hussain Ahmad, responded:

I will point out to the Brigadier that this is not the army, this is the Senate. People will come to democratic institutions to demonstrate and express their views. You should be magnanimous. It is not as though they have sent you here and nobody will bother you for six years. You are representatives and you will have contact with the people. They will object to your wrong deeds and praise you for your good deeds. You will have to bear these things patiently. You are doing public representation and you are retired from the army. ${ }^{11}$

\footnotetext{
${ }^{9}$ The prevalence of these local enforcers of prayers is unknown, but Zia-ul-Haq referred to them often.

${ }^{10}$ Zia-ul-Haq especially thanks these groups for making the referendum a success in an Address to the Nation on December 21, 1984.

${ }^{11}$ Senate of Pakistan Debates, September 28, 1986.
} 
While Zia-ul-Haq banned political parties and disallowed national elections for years, his approach to the state bureaucracy was to use it as a means of patronage (as did Bhutto), and a means further to militarize the state. Bhutto's earlier efforts to weaken the Civil Service of Pakistan through lateral recruitment facilitated Zia-ul-Haq's appointment of military officers throughout the bureaucracy. Military officers were appointed to one quarter of all senior bureaucratic positions, as well as to leadership positions in various planning bodies, public sector corporations and semi-autonomous organizations (Jalal, 1995:104-5; Nawaz, 2008:387). Military officers became governors of provinces and presidents of universities, and civil servants were closely watched as the military "appointed officers to dog and shadow civilians at all levels of the administration" (Nawaz, 2008:387).

\section{Islamic Welfare State}

While attempting to re-orient politics away from the national government, Zia-ulHaq also devised economic policies that were directed away from the central government, and in fact away from government altogether. He repeatedly lectured the country on the need for "simplicity," "austerity" and "self-reliance" as solutions to economic problems. ${ }^{12}$ Zia-ul-Haq saw a minimal role for the government in the economy and promoted the view that economic problems should be approached at the level of individual behaviour. For example, in a 1978 speech, he encouraged women to set up "Consumer Resistance Societies" to reduce their use of commodities such as food:

In history, we come across the instances of many countries whose people made tremendous sacrifices during war and other crises. For years they cut down the consumption of sugar, flour, milk, children's food, butter and other eatables to the

\footnotetext{
${ }^{12}$ Simplicity is a predominant theme in the discourse and practice of some religious groups in Pakistan, including the piety movement, Tablighi Jamaat.
} 
barest minimum. Can't we do the same? I will today request my mothers and sisters, who manage their houses, that if some commodities disappear or become scarce or their prices go up, they should organize resistance in their houses and refuse to run after things which are not likely to be available. ${ }^{13}$

Here a new political subjectivity was offered to Pakistan's overwhelmingly poor population - that of consumers who could exercise the choice not to eat. As a gesture of his willingness to make sacrifices and live "simply," Zia-ul-Haq regularly talked about allowing only "two dishes" to be served at meals in his home and only attending functions where no more than two dishes were served. This of course would only seem like a sacrifice in well-off households - the households that Zia-ul-Haq was implicitly addressing.

Echoes of three fundamental themes in Zia-ul-Haq's political discourse are evident in the preceding quotations. One is that women are dependent on men; they are consumers rather than producers; they are to be identified as mothers, sisters and daughters; and are to be referred to with possessive pronouns such as "my" and "our." A second fundamental theme is a moral critique of the "westernized" wealthy classes who are associated with previous forms of rule, and are prone to parties, feasts, lavish wedding ceremonies, "luxury living" and various other forms of material excess. The "two dish meal" (which later became the "one dish meal"), became a rallying point for the religious right in Pakistan, which called for an end to "extravagance" and "exhibitionism." A third theme is that of war and crisis: although the country was not at war, Zia-ul-Haq's invocation of "countries whose people made tremendous sacrifices during war and other crises" encouraged people to think of themselves as being at war and to accept the need for "drastic" measures and continued military rule.

${ }^{13}$ General Zia-ul-Haq, Address to the Nation, June 25, 1978. 
In place of state welfare policies that were either enacted or extolled in theory under the Bhutto regime, Zia-ul-Haq encouraged notions of private charity and at various points decreed the establishment of special funds for the "weak" (widows, orphans, and the handicapped) and the deserving needy (students of religious seminaries and refugees from the war in Afghanistan). The Islamic taxes of zakat and ushr, introduced by martial law ordinance in 1980, were central to the Islamic welfare system that Zia-ul-Haq sought to create in place of notions of universalist social welfare policy and a redistributive state. In announcing the taxes, Zia-ul-Haq declared that various Middle Eastern kings had made donations to the country's zakat fund, increasing the perception of a move toward private charity ${ }^{14}$ While zakat was collected centrally by a yearly deduction of a fixed percentage from bank accounts, ${ }^{15}$ it was administered locally by thousands of zakat committees staffed with individual volunteers. ${ }^{16}$ Funds were to be given by the central and provincial zakat committees to local zakat committees composed of "pious" individuals selected from among the "God-fearing" adults of the locality. In other words, the determination of need and provision of welfare were to be carried out by a combination of local religious figures and other influential persons rather than the state bureaucracy. Zakat payments were often distributed in the homes of zakat committee chairmen or in neighbourhood mosques (Parveen, 1982:36). The committees set up to collect and administer the taxes, identify recipients and to administer the distribution, restructured local power relations toward the new middle class and local religious figures.

\footnotetext{
${ }^{14}$ General Zia-ul-Haq, Address to the Nation, February 10, 1979.

${ }^{15}$ Provided that people had not emptied their accounts before the tax date.

${ }^{16} \mathrm{Ushr}$ is a proportion of agricultural produce. Most discussion of these taxes focuses on zakat because ushr was more difficult to implement (Gustafson and Richter, 1981) and is often subsumed in the discussion of zakat which is one of the five pillars of Islam (Clark, 1986).
} 


\section{Militarization, Islamism and Economic Liberalization}

While the social welfare function of the state was Islamized, other aspects of the economic and financial system were largely exempted. Islamization involved a reassertion of the primacy of the private sector and the adoption of a neoliberal economic platform. Zia-ul-Haq promised to prevent the state from interfering in the economy and to protect the sanctity of private property. Early initiatives signaled his desire to chart a different course than that of the PPP with regard to the private sector. For example, in his first cabinet, Zia-ul-Haq appointed an industry advisor who owned a nationalized car company, and who had been arrested during the Bhutto government's early actions against the industrial elite. A five year plan was drafted for the1978-1983 period with the main goal being "to bring the private sector back into partnership with the government" (Burki, 1991:100).

In 1979 two events changed Pakistan's relations with western governments and financial agencies: the overthrow of the Shah of Iran and establishment of an Islamic regime, and the entry of the Soviet Army into Afghanistan. On the heels of these events, the IMF, World Bank, United States, Japan and Western Europe "firmly endorsed" the Zia-ul-Haq regime and began to provide it with aid packages worth billions of dollars (Richter, 1982). In return for IMF aid, Pakistan eased restrictions on imported goods and pursued greater deregulation of the economy. In 1985, World Bank economist, Mahbubul-Haq, became Finance Minister in the Junejo government and "produced a program for the liberalization, privatization, deregulation, and globalization of the economy" (Cohen, 2004: 250). Pakistan continued to receive large amounts of aid from Saudi Arabia and the Persian Gulf kingdoms, and remittances from workers in the Middle East constituted a 
huge proportion of the country's GDP. While Zia-ul-Haq preached self-reliance and not begging for money from international sources, the country's economy was staked on foreign assistance and expatriate remittances. By the early 1980s Pakistan had become the third largest recipient of American aid following Israel and Egypt. The military continued to extract a phenomenal proportion of the country's wealth. Some of this appropriation exceeded that recorded in defense budgets as the military increasingly extracted resources from civilian sectors of state and economy for the personal benefit of its members (Siddiqa, 2007), a process facilitated by the appointment of military personnel throughout the bureaucracy.

The confluence of militarism and Islamism functioned to facilitate the suppression of trade unions and to create a favourable investment climate for global corporations. One interview participant described how the American-headquartered pharmaceutical company she worked for hired a retired brigadier from the Pakistan army to manage their strike-besieged Lahore plant. This allowed the company to avail itself of the tactics available to the military state, including control over the media and the use of Islamist groups to quell popular protest. A range of tactics were then used to break the union, including publishing the names of the women who belonged to the union in the newspaper along with charges against them; sending "vulgar letters" to their families; and arranging for Islamist men to fire their rifles at the feet of the women organizing outside the plant and to threaten and intimidate them as they made their way home from work. Cynthia Enloe (2007) has discussed the symbiotic relationship that grew during the 1980s between militarized governments and global corporations looking for compliant workforces. In the case of Pakistan, this relationship was with a military regime pursuing 
a larger program of Islamization, a central component of which was an attack on the morality of working women.

While GDP grew steadily during the 1980s, so did Pakistan's indebtedness. Mahbub-ul-Haq was forced out of his position as Finance Minister in 1986 when he tried to increase government revenue through agricultural and business taxes. Powerful commercial and agricultural groups in Pakistan remained unwilling to accept taxation (Cohen, 2004:250). After the dismissal of the National Assembly in 1988, Mahbub-ulHaq returned as Finance Minister in Zia-ul-Haq's "caretaker government", and reported that the country was facing a "bankruptcy situation" (Burki, 1991:109).

\section{Shariat and Military Justice}

The regime made many efforts to introduce Islamic laws and expand the judicial role of the ulama. Several Islamic laws were introduced by martial law ordinance, the first being the Hudood Ordinance of 1979, which prescribed punishments such as amputation of limbs, flogging and stoning to death for the crimes of alcohol consumption, theft, bearing false witness, and the new crimes of adultery and fornication. Zia-ul-Haq appointed more ulama to the Council of Islamic Ideology, a body set up in 1973 to examine the Islamic content of laws. This body began work drafting proposals

for new Islamic laws. In 1980, the Federal Shariat Court and the Shariat Appellate Bench were established. Members of the ulama were appointed as judges to these bodies in addition to judges with formal legal training. The jurisdiction of these courts excluded personal law, the constitution, financial matters, taxation and banking (Kennedy, 1990). They could rule on the Islamic nature of existing laws outside these areas; however, their role was mainly related to convictions and appeals under the Hudood Ordinance. 
A major impediment to the changes Zia-ul-Haq wanted to institute was the lack of institutions and personnel to support them. In 1979 a Shariat Faculty was opened at Quaid-i-Azam University in Islamabad to train more qualified experts in Shariat. In 1980 it became a separate Islamic University. The government also promoted the expansion of mosque schools and madrasahs, which I discuss below.

The implementation of Islamization was also hindered by resistance from existing judicial and law enforcement institutions. Judges were required to take an oath of loyalty to a martial law ordinance prohibiting them from questioning the authority or actions of the military leadership. Those who refused were dismissed, including several Supreme Court judges. Existing courts were reluctant to assign hudood punishments, leading Ziaul-Haq to complain that they had not been applied in even one case. ${ }^{17}$ (While the punishments of stoning and amputation were never carried out by the judicial system, the Hudood Ordinance did have other significant impacts, which I discuss in Chapter Six.) Military courts provided a parallel judicial system during the period of martial law; however, they also encountered obstacles working alongside the existing judicial system, as described by a member of the Punjab Women Lawyers Association. A group of women charged for participating in a pro-democracy demonstration appeared before a military court and were sentenced "within fifteen minutes" to fourteen years' rigorous imprisonment. However, prison staff were not prepared to carry out the sentence given the number of women and who they were:

There was a real fight going on between the prison authorities and the police on one side, and the military on the other side. [The former] felt we don't know what to do with these women, please take them away, we have absolutely no place, because...there were a lot of political prisoners. We women who were from a

${ }^{17}$ As he did in his opening address to the Eighth Session of the Majlis-e-Shoora on October 22, 1983. 
certain background, we were entitled to a certain class in the prison - our prisons are again class stratified. So they had to give us some space in that prison which they couldn't spare. And so we were very crowded, we were eighteen women in one room. I can't complain because I really had a very good time, but the [prison] authorities were really disturbed. They didn't know what to do, how they were going to keep us there... So the military had to cave in and we were released. (Interview 12)

Zia-ul-Haq frequently spoke of his desire for alternative "qazi" courts that would dispense "speedy justice" along the lines of military courts. This is not surprising given the tendency for appeals in the legal system to slow down the implementation of Islamization and to reverse the rulings of shariat and military courts. Qazi courts never became law. Neither did a Shariat Bill that was moved in the Senate in 1985 by members of the Jamaat-i-Islami, requiring that all laws in the country be in accordance with Hanafi shariat and that there be no appeals of the rulings of shariat courts in the regular courts. Those Islamization laws that were passed during Zia-ul-Haq's tenure were brought in during the period of martial law. Once elected assemblies were functioning again it became much more difficult to legislate Islamization, with the exception of the Eighth Constitutional Amendment passed in the early days of the Junejo government, protecting the laws and ordinances of the martial law period from any future court challenge.

While Zia-ul-Haq was often frustrated by the secular courts, the parallel judicial systems that came into being at this time did weaken the judiciary, as described by one interview participant.

You can see how the structure of the constitution changes, how parallel judiciaries emerge. There's the normal courts, there are the shariat courts. How conflicting jurisdictions have been created where the conflicts in the judicial pronouncements are becoming very apparent. If there are parallel jurisdictions, then you could see that the Federal Shariat Court would give much more conservative judgments than the High Court had given on the same issue. So these are things which have undermined the institutions ...those institutions will weaken because of these conflicts, they'll never be strengthened. (Interview 12) 
In many ways, extrajudicial and paramilitary activities were the more powerful techniques of Islamization, since the courts do not directly impact the lives of most Pakistanis. To enforce a wider program of reform, it was necessary to rely on the Jamaati-Islami, the IJT, or other Islamist groups, and to authorize local agents to police morality when and where they saw fit, creating another tension - touched on above - between local law enforcement institutions on the one had and the alliance of military and Islamists on the other.

\section{"Indigenous" Education}

The National Education Policy of 1979 was heavily influenced by the Jamaat-iIslami and other religious parties in Zia-ul-Haq's cabinet. Two key components of the policy were the Islamization and "indigenization" of education. The former involved introducing Islam into all subjects and disciplines in the school curriculum so that, as stated in the Education Policy, "Islamic ideology permeates the thinking of the younger generation and helps them with the necessary conviction and ability to refashion society according to Islamic tenets" (cited in Saigol, 1995:181). Islamiyat (Islamic studies) was also made a compulsory subject at all levels of the education system, including in civil service and medical school examinations. ${ }^{18}$

The "indigenization" of education entailed both an expansion of traditional religious schools, and an elevation of their standing to be recognized on par with modern schools. This involved projects to establish mosque schools, and the building of many new madrasahs. For example, during a two year period beginning in 1983, 4182 mosque

${ }^{18}$ The policy also sought to end co-education in universities through the establishment of a separate Women's University. (Other levels of education are almost entirely gender segregated.) This was never implemented but was under discussion for years. 
schools were established throughout the country. ${ }^{19}$ The curriculum of the religious schools was modified to include subjects from the general curriculum of schools, colleges and universities, particularly science subjects (Carroll, 1982:74). Madrasah education was declared comparable to university education in competition for government jobs (Haqqani, 2005:152). The proliferation of religious schools under Zia-ul-Haq and the neglect of public schools left the former as the only institutions available to the children of poorer families (Cohen, 2004:173). ${ }^{20}$ Much of the money for the building of new madrasahs came from foreign sources, particularly Saudi Arabia. This increased the influence in Pakistan of Wahabi Islam imported from Saudi Arabia, contradicting the stated purpose of "indigenization."

While the ulama expanded their control over education through a huge growth in the number of madrasahs, the Jamaat-i-Islami expanded its control of universities. Teachers were hired on the basis of their knowledge of the Quran. Universities were purged of liberal and left teachers with the help of the IJT (Nasr, 1993:269). Several of the women I interviewed were forced out of university positions during the early 1980 s. One participant recalls 30 faculty members leaving in the space of one year because it was "the Jamaat that ruled the roost" (interview 4). Another participant, commenting on the closing of the South Asia Institute at Punjab University during the early 1980s, commented: "I think the first indication that things were going to change rather rapidly was that we were told that Pakistan was taken out of South Asia" (Interview 11). While she described the Institute as being largely engaged in development research in the Pakistani context, the military-Islamist alliance assuming control over the universities

\footnotetext{
${ }^{19}$ The Senate of Pakistan Debates, Volume 3, August 20, 1985, p. 149.

${ }^{20}$ For those who are able to afford it, private schools are the preferred option.
} 
could not tolerate any assertion of commonality between Pakistan and India. While the universities were being undermined, separate private institutions were established at this time to train the business elite. Key among these was the Lahore University of Management Sciences (LUMS), affiliated with the Harvard School of Business and financed by endowments from business and industry.

\section{Reform of the Individual}

Zia-ul-Haq purposely sought to change feelings, sentiments, and embodied conduct away from those of secular national subjects. Zia-ul-Haq declared that "The reform of society in fact means the reform of the individual. ${ }^{.21}$ Any problems that the country faced were due to failings at the level of individual behaviour, particularly neglecting the performance of the rites of Islam. The most direct means for seeking to reform individual behaviour were: the educational reforms discussed above; countless directives issued to government offices, state controlled media, and educational institutions; and prescribing and proscribing media content. In this section I review three particular sets of practices that Zia-ul-Haq sought to reform - prayer, dress, and singing and dancing - that relate to the encouragement or discouragement of particular types of emotions, sentiments and embodied conduct.

Prayer

Zia-ul-Haq encouraged people to pray and to urge those around them to pray, claiming that the saying of prayers was vital in the reformation of society. Further, he declared that "every medium of mass communication, every educational institution, every

${ }^{21}$ General Zia-ul-Haq, Inaugural Address to the $4^{\text {th }}$ Session of the Federal Council, October 9, 1982. 
office, every factory will have also to play the role of a religious school., ${ }^{, 22}$ Heads of government departments were thus instructed to lead noon-day prayers in their offices. However, changing prayer from an individual or mosque-based practice into organized public practice was not straightforward. An interview participant from APWA described people telling her of multiple difficulties presented by the task of turning the social and physical environment of a government office into a pedagogical space for religious practice; for example, how could ablutions be performed before prayers if the office had no running water, would men line up for prayers behind a female supervisor, and if staff were sent home to pray would they come back?

In addition to prayer directives, the government sanctioned neighbourhood prayer monitors (Nazim-e-Salaat) who cajoled men into attending prayers in mosques. These measures offended the concept of religious practice held by many. Some women I interviewed offered perspectives on religious practice that emphasized liberal notions of equality, freedom and democracy:

[Islam is a] very simple, very pragmatic religion....And you do not need a priest or you do not need an expert, or an ulama, at any point to tell you anything....So I resent it. And I just feel that this freedom that has been granted to us by the religion should not be taken away. (Interview 5)

For me, Islam is also a religion of democracy in the sense that you're not to have exploiters and exploited...So I think it's just really difficult to bring in those things; the real equality that Islam enjoins, exploitation-free society, the moral life - you can't legislate it. Now tell me, can I legislate that you must only speak the truth and not be a back-biter? Could you legislate the same for me? It's not possible. (Interview 14)

By articulating a view of the moral autonomy on which liberalism depends, and by mapping Islam onto a horizontal social space, the women above indicate why they may

${ }^{22}$ Ibid. 
have been so closely associated by the regime and its supporters (as I suggest further in the next chapter) with a secular and liberal political order.

However, another interview participant who worked in the federal bureaucracy during the Zia-ul-Haq period put forth a reformist critique of Pakistanis whom she asserted tend toward being Muslim "by inheritance" only. She contrasted this to the behaviour of Muslims in other countries and spoke particularly about the need to emulate more religiously observant Muslims in the west. She reported being persuaded by the words of an American convert to Islam who told her: "Once we came to colonize you. I think we have to come back and remind you what is Islam" (Interview 18). This suggests the operation of an extra-national concept of space and community, also noted by Hirschkind (2001) in his research on piety movements in Egypt. Muslim practice in the west impacts that of Muslims in Pakistan, Egypt, and elsewhere. ${ }^{23}$

Zia-ul-Haq's efforts against the secular state are evident not only in his concepts of sovereignty but also in his approach to the practice of religion. Prayer directives in offices, official approval of neighbourhood prayer monitors, broadcasting the call to prayer and vast quantities of religious programming on television and radio, encouraged people to think of Islam before they acted or spoke, and provided constant reinforcement of the notion that religious observance cannot be a private affair. Prayer must be public in order to reform the public.

\section{Dress}

${ }^{23}$ One Egyptian told Hirschkind: "When one hears these things, like that people in the U.S. or in Bosnia are taking up Islam one is stirred. You ask yourself, if they are turning to Islam there, how is it that I as a Muslim am not even committed in my practice? ...So hearing this moves me toward committing to Islam and reforming my practice" (2001:1112). 
Three weeks after declaring martial law, Zia-ul-Haq began to instruct the citizens of Pakistan on their clothing practices. In an address to the nation on July 27, 1977, Ziaul-Haq declared "Henceforth, I expect that none of us will be averse to wearing national dress, i.e., Shalwar, Pajama, Kurta and Sherwani." The sherwani is a long, tailored coat worn by men that signifies respectability and formality. It is often worn on ceremonial occasions such as weddings. Politicians took to wearing it at this time and judges and upper level civil servants were required to wear it. While the sherwani may have served Zia-ul-Haq's purposes as an indigenous alternative to the western suit jacket, it is a relatively expensive piece of clothing, and hence at odds with his simplicity discourse. For men, the issue was that they should wear "national" dress, not "western dress," while for women it was that they should wear "Islamic dress." Multiple directives were issued to girls' schools and colleges requiring female staff to wear a chadar and students after Class IX at minimum a "proper dupatta as head cover." 24 The fact that colleges were not coeducational (apart from some male staff) did not dampen the government's desire to enforce chadar wearing. Over time, staff were pressured into following the directives, although students often flouted them (Mumtaz and Shaheed, 1987:79). Exhortations regarding dress for men were situated in a discourse linking the wearing of western shirts and trousers to westernization, acquisitive behaviour and lack of national pride. I suggest that for both men and women the directives regarding dress, like those regarding prayer, were intended to further inculcate a habituated consciousness of Islam through embodied practice.

\section{Singing and Dancing}

${ }^{24}$ A chadar is a large rectangular cloth worn over the head and around the shoulders. A dupatta is a long thin scarf, usually worn draped over the shoulders. 
Zia-ul-Haq stated repeatedly that singing and dancing were against the "ideology of Pakistan." After national and provincial parliaments resumed, religious parties frequently complained in the National Assembly and Senate about singing and dancing. ${ }^{25}$ Qazi Hussain Ahmad, who became leader of the Jamaat-i-Islami in 1987, complained that "Activities such as music functions divert the attention of the people from important matters" (Senate of Pakistan, July 13, 1986). Maulana Sami-ul-Haq, head of the Jamaat Ulama-i-Islam, complained in the Senate about a "blasphemous" Lahore High Court order instructing police not to interfere with professional musicians and dancers. A discussion ensued in which the Deputy Chairman of the Senate tried to suggest that there is an emotional benefit to music, to which Sami-ul-Haq responded that music is associated with sexual deviance only:

Deputy Chairman: Don't get me wrong but sometimes listening to music softens one's feelings. But of course I am against the kind of dance and music you mentioned- (interruption) Maulana Sami-ul-Haq: I referred to the dancing and singing that take place at brothels.

Deputy Chairman: I just meant how music can be relaxing. Maulana Sami-ul-Haq: For that matter, the shopping malls are filled with audio cassette shops and music centres.

Deputy Chairman: You want to close them down.

Maulana Sami-ul-Haq: In such shameless circumstances, what is the need to go to the brothels? (Senate of Pakistan, February 2, 1987)

Music and dance not only divert thoughts from God, but as collective activities they

foster a public life that is not centred on piety, and that which is not directed toward pious conduct is not virtuous - it is immoral.

Cultural life was increasingly conducted in a circumspect manner at this time. One interview participant said that directives prohibiting dancing were not heeded at the

${ }^{25}$ With a combination of appointed and indirectly elected members, many of the regime's key supporters were in the Senate rather than the National Assembly. 
school where she taught and no one ever came around to check their implementation. However, the effect was an increase in objections to dance among parents who were concerned that it was un-Islamic and/or illegal. Legislation, directives, speeches and media campaigns, together with prohibitions against political activities, constricted public life and led to a "retreat":

The atmosphere was very repressive so it was really as if you were doing things apart. You couldn't really be part of anything larger, you always had to worry about when somebody might come in or where to hold your Parents' Day, because you couldn't hold it in the Al-Hambra ${ }^{26}$ and have dancing and singing, so you had to have it on your premises and you had to be sure that you weren't inviting too much comment. So there was a retreat. (Interview 10)

For some, this period represented a retreat from collective life and into detached, individualized lives as the public became a realm of religious observance and little else. The attempts to discourage music and dance, promote prayer and shape Islamic dress, may also be seen as the attempt to create a new public life, or to create a new moral subject based on new "forms of will, desire, emotion, and reason, conceived of as intellectual and bodily aptitudes or virtues" for correct conduct in a new Muslim polity based not on a liberal and national political order, but on an Islamic "counterpublic" (Hirschkind, 2001:10).

\section{Sectarianism and Ethnic Violence}

The more Zia-ul-Haq emphasized Islam, the more divided Pakistan became. Legislating Islam necessitates the privileging of particular schools of interpretation over others. Sectarian conflict grew in part as a result of a process of extending patronage to a multitude of Islamic groups and individuals, in a context in which national politics were weakened and disallowed and government was being privatized to local agents enforcing

${ }^{26} \mathrm{An}$ arts and culture centre in Lahore. 
their versions of what an Islamic system should be. Other features of the regime that were congenial to the growth of sectarian and ethnic conflict were the proliferation of weapons and the training of Islamic militants related to the war in Afghanistan (discussed in the following section), the strong commitment of the regime to the idea of being at war and in a state of crisis, the proliferation of madrasahs from which the leadership of sectarian organizations emerged, and the encouragement of gun ownership and the youthful male vigilante which I discuss further in Chapter Six.

Zia-ul-Haq patronized a host of Islamic groups and individuals, including various ulama, Sufi pirs and religious leaders, the Islamic political parties, and the Tablighi Jamaat, thereby simultaneously pleasing and antagonizing many and preventing any single group from becoming too powerful, including the Jamaat-i-Islami which over time was at a loss as to whether to continue collaborating with the government or to make overtures to the $\mathrm{MRD} .^{27}$ In addition to inducting members of the religious parties into his government, Zia-ul-Haq allowed the Tablighi Jamaat to conduct missionary work within the army and began holding Mushaikh (religious leaders) conferences and seminars around the country (Haqqani, 2005:139, 150). Prominent among the recipients of zakat were madrasahs, students of madrasahs and various Islamist groups whose influence expanded as a result of their involvement in the administration of zakat (Cohen, 2004: 182; Haqqani, 2005:141; Ziring, 1988:807).

The general empowerment of various Islamic groups and local religious figures made life in Pakistan increasingly difficult for Christians and Ahmedis who began to suffer greater harassment. Shia Muslims also became a target of those who had already

${ }^{27}$ See Nasr (1993) for an account of the increasingly strained relations between the Jamaat-i-Islami and Zia-ul-Haq's government. 
succeeded in attaining state endorsement of the view that Ahmedis were not Muslims.

Shias were also beginning to assert a stronger group identity. The imposition of zakat based on Sunni law led to mass protest among the Shia community in Pakistan, forcing the government to exempt them from payment of the tax. Other factors, including the 1979 success of Shia clerics in Iran, and the ascendance of Sunni Hanafi fiqh via Zia-ulHaq's Islamization platform, fostered increasing political activism among Shia groups in Pakistan, and more clashes between Shia and Sunni groups beginning in the early 1980s (Zaman, 1998:699).

The military government is believed to have played a direct role in patronizing some of the most violent ethnic and religious sectarian groups that first appeared in the mid-1980s. One of these was the Sipah-e-Sahaba, a newly formed Sunni sectarian organization that began a campaign of assassinating prominent Pakistanis of Shia background (Cohen, 2004:186; Jalal, 2008:278). Although Shias are a minority in Pakistan, they are well-represented among urban professionals and the landholding elite. A critique of these elites figures prominently in polemics against the Shia, such as the following extract from a Sipah-e-Sahaba member's biography of the group's founder who hailed from the Punjabi city of Jhang:

Jhang was a backward district dominated by feudal lords (jagirdars)...They found license in Shi'ism for the life of pleasure and libertinism they desired, and so the rural gentry had become Shi' $i$. Under their influence, the peasants and other members of the 'lower castes' also went over to Shi' ism. But even those who didn't had remained neither Shi'i nor Sunni, and had no sense of shame at being devoid of religious identity. Sunk in ignorance, they retained some of their traditional customs in the name of Sunnism (sunniyat), while in other respects they had become assimilated with the Shi'a. They know nothing of their beliefs, nor of their religious orientation (maslak); they did not practice their faith, nor were they bothered about not practicing it. All they had were certain rites of ignorance (rusum-i-jahiliyyat) and nothing else. (Balakoti, cited in Zaman, 700:1998). 
As the above quotation suggests, the Sipaha-e-Sahaba is situated within reformist, not traditional rural Islam; it demonstrates the objection to so-labeled decadent elites and ignorant masses that is a hallmark of reformist tracts seeking to substantiate middle class moral authority. A significant feature of this variant of reformist Islam is the use of increasingly violent means to demarcate the boundary between Sunni and Shia. This violence, originating during the 1980 s, has continued with assassinations and with periodic attacks on Shia and Sunni mosques.

Another organization that emerged at this time fostered ethnic rather than sectarian conflict. In the mid-1980s, Muhajir group identity, which traditionally was articulated largely through the Jamaat-i-Islami, began to coalesce around the newlyestablished Muhajir Qaumi Mahaz (Muhajir National Movement). Formed in 1984, the MQM was a youthful, male organization, like the Jamaat-i-Islami's youth wing, and its tactics were similar, though now channeled into larger scale urban warfare rather than focused on university campuses, and cast as an ethnic struggle between Muhajirs on the one hand and Pashtun migrants to urban Sindh, and sometimes Sindhis, on the other hand. The MQM is widely believed to have been encouraged and armed by the military as a means of countering the ANP, which had widespread support among the large Pashtun community in Karachi, and which was a prominent party within the MRD (Nasr, 1993:275-76). In August of 1986, the MQM appeared suddenly and violently on the scene, clashing with the Pashtun community in Karachi. The resulting violence, described as "the worst communal fighting since 1947," continued for years (Shaheed, 1990; Ziring, 1988:808). 
Though the Sipah-e-Sahaba was sectarian and the MQM was an ethnic organization, both organizations reflect attributes of a new type of political movement. An interesting point to note is that both moved onto recruiting ground traditionally occupied by the Jamaat-i-Islami, or its student branch, and the established parties of the ulama, particularly the Jamaat-Ulama-i-Islam (JUI). Though both organizations would come to participate in electoral politics, ${ }^{28}$ they did not focus on a state-centred agenda; for example, they did not focus on the Islamic content of constitutions or laws, on increasing their power within government, or on articulating a coherent political ideology or program such as "Islamic revolution." Rather, they represented a politics that centred on establishing spaces outside government and existing structures of political authority. Fraternities in arms, they seek to capture territory or establish spaces outside government and existing structures of political authority (compounds, urban enclaves), remove or shame existing authorities often through symbolic acts of leveling, enforce rituals that denote membership and acquiescence to their rule, and display their prowess by, for example, parading with guns or through acts of violence or destruction. In his ethnography of the MQM in one Muhajir neighbourhood in Hyderabad, Sindh's second largest city, Verkaaik describes how the MQM evicted the last vestige of state power - in the form of the Sindh Archeological Department - from their neighbourhood known as Pakka Qila in 1987, after which Pakka Qila became a "symbolic free town of the MQM" for the next three years (2004:131). They did not declare the rule of "shariat," but rather referred to themselves as "qila quam" (people of Pakka Qila), who were answerable to no government or religious authority. They bear similarities to the Jamaat-i-Islami in their valuation of male virility and a martial masculinity, but this is taken to a new extreme.

${ }^{28}$ Though the Sipah-e-Sahaba was banned in 2002. 
The MQM, like religious sectarian organizations proliferating at this time, were characterized by a politics of assassination, cycles of violent retribution, as well as a willingness of individual members to endure physical hardship, martyrdom, and exile.

\section{Jihad}

The jihad (struggle), defined in this context as "holy war," against the Soviet occupation of Afghanistan during the 1980s vastly increased the organizational capacity, military training and funding of Islamist groups in Pakistan. The USSR sent troops into Afghanistan in December of 1979 to support the shaky communist government, beset by factional infighting after its April 1978 coup. During the 1980s Pakistan took in over three million refugees from the ensuing conflict and became a staging ground for a war against the Soviet army and the Democratic Republic of Afghanistan (DRA) regime. ${ }^{29}$ Reminiscent of the PNA movement against Bhutto, Islamist politics were the rallying cry against the statist project of the Afghan communist government. The war against the Soviet occupation was conducted by Pakistan's ISI and the American Central Intelligence Agency (CIA). Saudi Arabia was a major contributor of funds along with the United States. A number of other western countries and China were also involved. Islamist groups in Pakistan were involved in administering the Afghan refugee camps and in the training of resistance fighters who became known as the Mujahideen. ${ }^{30}$

Money, weapons and the supply of men to fight were channeled through seven Islamic parties in Pakistan. The refugee camps in Pakistan were their recruiting ground.

\footnotetext{
${ }^{29}$ Iran also took in up to three million refugees, but the largest group of refugees during the first few years of the conflict went to Pakistan (Khattak, 2003:207).

${ }^{30}$ Mujahideen are those who engage in jihad or struggle, but the term was widely translated at this time as "freedom fighters."
} 
Afghan families would not receive help unless the men agreed to undergo military training and return to Afghanistan to fight the jihad:

Refugee registration, consisting of entitlement to food, shelter and services such as health and education, could take place only after a declaration of allegiance to one of the seven political parties crafted by the ISI. The declaration of allegiance required men to go back and fight in Afghanistan after receiving training in a border camp (Khattak, 2004:219).

Many of the refugees were required to sign up with the Hezb-i-Islami, led by the very brutal Gulbuddin Hekmatyar, which was seen by many refugees as an enemy on par with the USSR (Baitenmann, 1990:66). The United States' government, the largest single funder of the Afghan refugee program in Pakistan, pressured the United Nations High Commission for Refugees (UNHCR) not to interfere with this blurring of the distinction between refugees and resistance fighters (Ibid:67-68).

Pakistan's military and its allies trained 20,000 Mujahideen a year, and members of Islamist parties, students of madrasahs, and volunteer fighters from around the world also received training at the camps (Haqqani, 2005:194). The camps in Pakistan hence provided military training to Islamists in a global context. The prospect of foreign nationals being allowed to enter Pakistan, receive military training, carry weapons and roam freely, suggests that Pakistan's government was working with loose concepts of citizenship and territorial sovereignty. The concept and practice of jihad, in its contemporary articulation, is a key force undermining the nation-state in Pakistan.

The international community donated billions of dollars to assist in the conduct of the war and largely remained silent about what took place in the refugee camps. From the beginning, a central objection of those fleeing the DRA administration was the forced education of women and girls. According to Valentine Moghadam (1993:229), the first 
set of refugees crossing the border into Pakistan in 1978 cited forced literacy training for women as their main reason for leaving. Again, literacy training is a technology of national government, objectionable to many in a tribal society. Employment and education or literacy training for women were largely disallowed in the refugee camps, and women had little option to leave if they experienced abuse. A strict form of seclusion of women was practiced in the camps, although men were free to come and go. The Mujahideen did not have spokeswomen or women's wings. International agencies accepted the strict control of women so as not to cause conflict with the Mujahideen leadership. For example, one UNHCR program that provided 87 million dollars over ten years for income generation among the mostly female refugee population never employed a single woman (Khattak, 2004:231).

In a 1939 lecture, Maududi critiqued the construal of jihad as "holy war" and dated the "by the sword" concept of Islam to the advent of western colonialism and the western encounter with Islam in the process of colonizing Muslim lands (Choueiri, 1997:145-46; Jalal, 2008). Nevertheless, in 1979, the Jamaat-i-Islami leadership, including Maududi, met with Pakistan's military to plan and participate in a "holy war" against the Afghan government (Nasr, 1994:195). The actions of the ISI, the CIA, the Saudi leadership and other agencies and governments during the 1980s furthered this notion of jihad, creating thousands of "jihadis" or militarized young men with a violent and dogmatic understanding of Islam. This was done through the supply of funds, weapons, expertise in guerilla warfare, coordination and organization of groups of Mujahideen, and through the production of school texts emphasizing a militant view of 
Islam. ${ }^{31}$ These trained fighters would come to constitute non-governmental armies that would act sometimes in concert with the objectives of future civilian governments and the Pakistan military - objectives which are not necessarily one and the same - but at other times would act outside the interests and control of Pakistan's state executives.

The Afghan jihad immeasurably increased the militarization of Pakistani society. Vast quantities of weapons for the Mujahideen flooded into the country from many international sources, and many came to be traded in Pakistan rather than used in the war. Possession and use of guns spread throughout the country. The refugee camps became a separate jurisdiction in which Islamist rule prevailed. The military training of Islamist groups, funding for more madrasahs and mosques, and the spread of weapons, also contributed to increased levels of violence and sectarian conflict in Pakistan. The favouritism that the Pakistan military showed to groups of Deobandi ulama in the NWFP and Baluchistan, who shared a similar culture with many of the Pashtun refugees from Afghanistan, led to increased mosque and madrasah building by other sects (Jalal, 2008:276). Finally, the jihad brought international support and funding to the Zia-ul-Haq regime and the Pakistan military, weakening the prospects for a return to civilian rule. While Pakistan's military leadership was heavily invested in determining who would form the government in Afghanistan after the withdrawal of Soviet troops, even politicians who collaborated with military rule could see the heavy toll the war was

\footnotetext{
${ }^{31}$ With funding from the United States International Aid Agency (USAID), textbooks for Afghan children in the refugee camps were produced at the University of Nebraska beginning in 1984. These texts contained violent imagery, glorified militant Islam and promoted the waging of holy war. They also normalized women's seclusion. They continued to be used after the Mujahideen overthrew Afghanistan's communist government in 1992, but eventually had to be changed because Afghan children, having considerable direct experience of war, were terrified and disturbed by them (Canadian Broadcasting Corporation, 2009).
} 
taking on Pakistan. Prime Minister Junejo's opposition to the military's Afghan policy was a key reason for his dismissal by Zia-ul-Haq in 1988 (Rais, 1989).

\section{Conclusion}

In this chapter, I have suggested that Islamization represented an attempt through various means to deconstruct and transform those political forms - whether liberal or socialist - and their accompanying institutions and practices that emphasized nation and society. Instead of the nation there is the need to align oneself with the word of God; instead of society there are individuals. This was done through disallowing elections, amending the constitution to weaken parliaments, banning political parties, localizing the political field, attempting to bludgeon the left, favouring military and shariat courts and paramilitary and extrajudicial enforcement, privatizing the economy and social welfare, trying to Islamize all forms of thought and knowledge, creating an education system led by the ulama, promoting practices of the self that emphasize personal piety, and through a pervasive militarization.

Militarism, Islamism and anti-westernism were evident during the Bhutto period as well. However, Bhutto's militarism was situated in a national rather than Islamist logic, and however populist and ill-defined it may have been, Islamic Socialism was premised on the (secular) idea of society as an entity that must be tended to - as composed of social groups with social needs within a national territory. And though there was a component of dictatorial machismo in his anti-western rhetoric, the political movement Bhutto led employed a critique of imperialism, neo-colonialism and exploitation that was situated within a politics of national sovereignty and national selfdetermination. Zia-ul-Haq's critique of the west, like that of Maududi and of the 
movement behind the PNA, was directed primarily at elites within Pakistan who were labeled as westernized and associated with liberalism or socialism and a secular political order. The cultural critique of elites was about more than their acquisitiveness and western personal habits; it was about undermining cultural forms - institutions, feelings, embodiment, and the spatial and temporal organization of life - that support a national political order. In the next chapter I consider why women were so central in this project of Islamization. 


\section{Chapter Six \\ Islamization under Zia-ul-Haq, Part 2: Remaking Women}

\section{Introduction}

In the preceding chapter I discussed the Zia-ul-Haq government's multifaceted attempts to deconstruct the nation. This chapter also focuses on the process of denationalization, particularly on one key aspect: the political project of Islamizing or reIslamizing women. A vow to maintain the sanctity of the chadar (veil) and chardiwari (four walls of the home) figured prominently in Zia-ul-Haq's speeches. "Chadar aor chardiwari" is a reference to purdah but, as Zia-ul-Haq himself explained, in using the phrase he was not literally referring to the seclusion of women in homes but to something broader: "that the administration was responsible for protecting the life, honour and property of citizens of Pakistan" (Dawn Overseas Weekly, April 15, 1978, quoted in Carroll, 1982). I suggest here that the veil and the four walls was a spatial metaphor counterposed to the spatial metaphor of the nation. Sanctity lies not in the nation, but in chadar and chardiwari, and middle class women constitute a primary fault line in a shifting political landscape.

The regime of Zia-ul-Haq appeared to be "obsessed" with women, with what they do, where they go, what they wear, and how they act. This was expressed in laws, ordinances, state directives, media campaigns and other measures involving women undertaken by the government. In this chapter, I describe actions of the regime equating women's presence in public with immorality and obscenity, reducing women's legal status as equal citizens, criminalizing women through new adultery and fornication laws, and demarcating masculine and feminine dress, behaviour and space. I also examine 
responses of women to the project of Islamization and their accounts of the broader impact of the Zia-ul-Haq period. For this I rely largely on the interview accounts of 20 members of the Women's Action Forum (WAF), an umbrella organization that was formed in 1981 to oppose the actions of the regime related to its Islamization platform. Often accused of representing a small group of elite women, WAF's emergence at a time of martial law when there was little else in the way of opposition to the regime to challenge the government directly, and the fact that this was precisely the group of women targeted by Zia-ul-Haq's policies (though not the only group affected), make its members of particular interest in understanding changes in the gender order accompanying changes in the political order during this period. They did not represent all or even most women in Pakistan. They are reflective of those women who were derisively identified in the project of Islamization with previous structures of state authority - in other words urban working women whose conduct was identified with the nation, the constitution, social welfare and secularism.

\section{Islamizing Women}

The Reorganization of Gendered Space

While the populism of the 1970 s had been characterized by a blurring of gender distinctions (Rouse, 1997), the Islamist-military alliance of 1977-1988 sought clearly to separate and demarcate masculine and feminine, and to re-assert purdah in multiple ways. In contrast to nationalist discourse emphasizing citizenship and social welfare, Islamist discourse conceives of the public sphere as one of sexual deviance, obscenity, nudity, immorality, and prostitution. As Choudry Mahmoud Ahmad, General Secretary of the Jamaat-i-Islami, stated in 1983: "The cornerstone of the Islamic system is the prevention 
of obscenity, nudity and an end to mixed society" (quoted in Fullerton, 1983:35). This necessitates constant vigilance around gender segregation and the devotion of the public sphere to pious performance. Secular nationalism had restricted Islam to private belief and brought it under the control of the juridical powers of the state. The Islamizing military regime of Zia-ul-Haq represented a return of Islam to the public and to public institutions. This was not accomplished solely by elevating the position of mosque, maulvi and madrasah. All public spaces - streets, factories, offices, television and radio broadcasts, schools, market places and government institutions - were envisioned as a terrain of piety and devotion. As such, the presence of women in public space is problematic, particularly if they are unveiled, in the company of unrelated men, and engaging in pursuits other than the care of family members.

Thus, bolstering norms of purdah was a key component of Zia-ul-Haq's agenda, and after seizing executive control of the state he quickly followed through with a number of actions. The government began a media campaign urging people to observe strict Islamic practices and to police their neighbours. This was followed by a number of incidents of men confronting women about the way they were dressed in public spaces, and in some cases women were slapped or physically assaulted by men they did not know (Mumtaz and Shaheed, 1987:71). While formerly physical assaults on women for the way there were dressed were not unheard of in crowded inner city areas, at this time the incidents began occurring in wealthier areas of cities. Couples were also stopped on the street and called upon to explain their relationships. A number of women I interviewed related their own experiences of being stopped during this period by groups of men or by police while out walking or driving with male companions and ordered to produce their 
nikah namas (marriage certificates) on the spot as evidence that they were married. Policing gender interaction was a technique used by the Jamaat-i-Islami's student wing, the IJT, on university campuses as a means of establishing their authority over campus space. This technique was now used in a larger context to establish authority over city neighbourhoods, including wealthier neighbourhoods. It was a means to establish the authority of those doing the policing and to deny the moral respectability of those accosted. Its occurrence in wealthier neighbourhoods suggests a challenge to the moral authority of more powerful sections of Pakistani society. The practice of policing gender interaction in public areas, by police or vigilantes, was supported by the introduction of laws criminalizing adultery in 1979, which I discuss in the following section, and was promoted by many sections of Islamist opinion within the media and elsewhere.

The government issued directives requiring women to wear chadars in government offices, on Pakistan Television and in public schools - areas of direct government control. Zia-ul-Haq also presented chadars as gifts to women he met in the course of official functions. Women were also told they could no longer wear saris to work. Though worn by millions of Muslim women in South Asia, the sari was portrayed by the regime as a Hindu form of dress. One WAF member I interviewed who only wore saris refused to change her wardrobe and recounted frequent discussions and deliberations at her government workplace on what to do about the way she was dressed. The government issued periodic instructions to curtail women's employment and promotion in certain areas, many of which had only just been opened to women under the PPP government. At various times beginning in the early 1980s women found they could no longer obtain Foreign Office postings, scholarships to study abroad, or employment in 
banks (nationalized under Bhutto). Female athletes were barred altogether from traveling abroad to compete. Within Pakistan they could compete only in front of all-female audiences in competitions that could not be broadcast and even then many of their competitions were cancelled without explanation, indicating that the activity itself was one the regime objected to, not merely the possibility of a male audience. To avoid disqualification by international sports associations on the grounds of gender discrimination, the government issued no written policies explicitly barring women from competing, claiming only that the women were simply "not up to standard." The religious parties were the key lobby behind the restrictions on women's sports, monitoring and protesting any breach in the restrictions throughout the 1980s (Mumtaz and Shaheed, 1987:90).

In 1982 the government began a campaign against "obscenity." Directives were issued limiting the appearance of women in television commercials. Women could only appear for a brief portion of time and only endorsing products "of relevance to women." In effect, this meant that unless women were clearly portrayed as mothers and housewives, the advertisement would be deemed obscene. Pictures of female film actors and athletes were banned from the print media. The state-initiated discourse on women and obscenity spilled over into debates within the media and elsewhere in which women's presence in public was equated with obscenity (Mumtaz and Shaheed, 1987:81). There was a plethora of religious programs on state controlled television at this time. One program called " $A l \mathrm{Huda"} \mathrm{was} \mathrm{a} \mathrm{platform} \mathrm{for} \mathrm{Dr.} \mathrm{Israr} \mathrm{Ahmed,} \mathrm{a} \mathrm{member} \mathrm{of}$ the Council of Islamic Ideology and the Majlis-i-Shoora, who argued that women should not be allowed employment outside the home and in fact should not leave their homes at 
all except in emergencies. He also advocated the use of young male vigilantes to intimidate women in public places (Ibid: 84). According to one WAF member, "that's when women started to feel very threatened because his program became very popular. ...There weren't too many T.V. channels, the dish antenna hadn't come, so everybody was hooked onto $\underline{\mathrm{Al} \mathrm{Huda}}$, and it was really upsetting" (Interview 1). ${ }^{1}$

The Council of Islamic Ideology - a body set up under the 1973 constitution to review laws for their accordance with Islam - began to pronounce regularly on what women could or could not do and to formulate laws affecting women which I review in the next section. A range of government commissions and bodies were set up at various points as well, including a Women's Division set up in 1979. These government bodies discussed and proposed such things as restricting women's ability to travel, their ability to participate in political activity, and the type of education and employment that should be available to them. For his part, Zia-ul-Haq stated that he had no intention of preventing women from working, but that "Women must pursue professions in which they are most suited."

While it appeared at times that women were officially seen as the source of "all immorality, corruption and vice" (Said Khan, 1988:11), it was particular women in particular spaces - working women and women in public spaces - who were targeted as potential sources of corruption and immorality:

You were constantly seeing things on the television which suggested that women who were independent, women who were working, women who are mobile,

\footnotetext{
${ }^{1}$ Dish antennas allowing reception of international television stations began to be widely available in the 1990s.

${ }^{2}$ Interview with President General Mohammad Zia-ul-Haq by Panel of National Journalists, Rawalpindi, January 25, 1985.
} 
women who decided things for themselves, were bad and were responsible for disintegrating society and furthermore were un-Islamic. (Interview 11)

Women in the home caring for family members were a source of honour and morality. This message was conveyed repeatedly. Good women were those who were married and remained secluded, taking care of husbands, in-laws and children. A sharp contrast was drawn between the immoral woman-as-prostitute of the public sphere and the chaste or asexual wife/mother of the private sphere.

The association of working women with obscenity was reflected in popular culture during the Zia-ul-Haq era. In a study comparing television dramas aired on Pakistan Television (PTV) in 1985-86 with videotapes of programs produced in earlier decades, Hussain (1996) found that the quintessential "bad woman" in television dramas of the Zia-ul-Haq period was the single working woman. Prior to this period, the only type of female character depicted as operative in the public male world, or the world of economic transactions, was the "vamp" or the prostitute. During the Zia-ul-Haq era, depictions of prostitutes would occur in cinema where the primary audience is adult men, but not on PTV which is assumed to have a "family" audience (Sher, 1996:46). However, the independent working woman portrayed on television in the 1980s shared something in common with the prostitute of film: her "unbridled sexuality" (Hussain, 1996:36). The independent working woman also began to appear in film during the Zia-ul-Haq era, and was "shown as being 'westernised', a term that is more or less synonymous with moral depravity and the absence of emotions associated with motherhood, such as nurturance and self-sacrifice" (Sher, 1996:45). A parallel with the writing of Maududi is evident here: "westernized" women are represented as akin to prostitutes. During the Zia-ul-Haq 
era, this westernization and sexualization is transferred to working women or any woman active in the public economic sphere, which is the preserve of men in Islamist discourse.

Observance of aspects of purdah was directly legislated in a few instances, such as chadar directives to government offices and educational institutions, and a 1986 resolution by the provincial assembly in NWFP prescribing punishment for women who did not observe purdah. For the most part, however, the regime tried to shape practice through cultural output and its preferred technique of male vigilantism. These techniques were much more effective than the often-ignored directives and laws. One interview participant describes how far the government was able to go in curtailing the public lives of women without enacting laws explicitly confining women:

The state was acting through ideology. It was acting through every man on the street. Any man could come up to you and say is this your husband or not? Any man could come up to you and say why are you not at home? Any man could come up to you and say put your dupatta on your head. Every man could say why are you standing at the bus stop? Because you're there and you're not meant to be there. The state is saying the woman who's out is asking for it. (Interview 4)

According to one interview participant, the changing environment was felt most acutely

by precisely that group of women whose behaviour the regime disliked:

I think women who were working, irrespective of their class background, really felt much more of the everyday pressure and the changing atmosphere as they went out to work, as they were walking on the streets, as they were taking buses, et cetera, than women who stayed more secluded from that interaction. (Interview 11)

Dress directives served as a constant reminder to women of the uncontrolled sexuality and immorality of their bodies. It was a difficult pressure even for women who opposed the regime to deflect: 'It's something very difficult to describe unless one has actually lived through it because suddenly you are conscious of your body, you've been told literally what to wear and who to talk to and it changed all of us. It changed all of us 
despite ourselves" (Interview 4). Another participant echoed these comments about a tendency to internalize the regime's point of view even while consciously opposing it:

I remember intellectually saying 'what the hell?' and emotionally being on the defensive and either being evasive or trying to justify what didn't need justification...Like what was she doing outside if somebody was rude to her, or if somebody abused her? And instead of saying well why the hell should anyone abuse anyone anywhere, you said 'no, no, no, but she was only taking the kids to the doctor.' (Interview 3)

These comments reveal the regime's success at simultaneously sexualizing women and leaving women with the feeling that their only legitimate role is motherhood.

The Women's Division formulated programs focused on "feminine skills" such as sewing and secretarial skills. In rural areas there was a focus on income generation projects geared to the production of consumer products such as jams and jellies based on a conception of rural women as peripheral to the agricultural economy. A substantial proportion of agricultural labour, particularly that done close to living areas, is performed by women including post-harvest processing operations and raising animals (Kazi, 1991). However, Women's Division programs minimized women's role as producers. In this respect they were not radically different from previous official policies ignoring women's "mainstream role in the agricultural economy" and instead conceiving of women as primarily concerned with home-based income generation through such tasks as embroidery and jam-making (Said Khan, 1988:19). However, as I touch on again later in this chapter, this approach gained greater ascendance with the decline of the state sector and the emergence of development programs delivered by non-governmental organizations (NGOs) that often shared an approach of ignoring women's role as agricultural producers in favour of home-based income generation in the informal sector (Rouse, 1997:160). 


\section{Islamic Laws}

Islamic laws undermined notions of citizenship, and by criminalizing women's sexuality and making women responsible for community honour, they provided another means of de-feminizing the public sphere. The first set of legal changes under Islamization, and the ones that had the most significant impact on thousands of women, were the Hudood Ordinances of 1979. These laws designated adultery and fornication (zina), rape, prostitution, bearing false testimony of zina (qazf), theft, armed robbery, and alcohol consumption as crimes against the state subject to Islamic punishments including flogging, amputation of hands or feet, and stoning to death. Each of these crimes had two types of sentences, Hadd (maximum) and tazir, with different requirements for proof. Evidence for Hadd convictions is more stringent and sentences more extreme. The law also required the testimony of four adult Muslim male witnesses of good character to prove any of the first three offenses (zina, rape, and prostitution) under Hadd, and the sentence was stoning to death. ${ }^{3}$

It was the lesser conviction of tazir that was by far the most commonly applied, and particularly for zina offenses. While not as extreme as hadd, tazir punishments are harsh nonetheless. Public whipping, which did not exist in Pakistan's penal codes prior to this, became mandatory under tazir for zina, rape and qazf convictions. Jahangir and Jilani write that "Tazir for theft, armed robbery, drinking and use of drugs has not made a substantial difference in the law or its application. The tazir punishments awarded under

\footnotetext{
${ }^{3}$ In 1981, a year after it was created, the Federal Shariat Court ruled that stoning to death was not in fact an Islamic punishment. Zia-ul-Haq then reconstituted the Federal Shariat Court bench to secure a judgment affirming stoning to death as an Islamic punishment (Jahangir and Jilani, 1990:24-29).
} 
the Offence of Zina have been the most operative part of the Hudood Ordinances" $(1990: 84)$.

The Zina Ordinance converted adultery into a criminal offense in Pakistan and created the new crime of fornication. Under this new law, many rape victims faced charges of adultery or fornication. If a woman brought a charge of rape and the man was found not guilty, then the woman could be charged with zina on the basis that she had admitted to sexual relations with the man. Thus the law created a situation in which women who report rape risk prosecution themselves. With the introduction of the new crime of adultery, courts would often convert rape to zina on the assumption that a woman would claim rape to escape a charge of adultery (Zia, 1994:29). In addition, if a woman became pregnant as a result of rape, the pregnancy could be used as evidence that she had committed zina. Pregnancies and rape accusations interpreted by courts as adultery confessions resulted in many convictions of women for zina, but not the "coaccused" men who were acquitted for lack of proof. The Hudood Ordinances also abolished the crime of rape within marriage and statutory rape (sexual intercourse with a person under the age of fourteen).

The Zina Ordinance illustrates two key things about the gender order envisaged by those who created it. First, it encodes into law the notion of woman as vamp. Outside of chadar and chardiwari, the female is a menacing figure who exercises force over men through seduction; hence the legal undermining of the category of rape as distinct from adultery and fornication. Secondly, it privileges the protection of the collective notion of honour over the protection of individual rights and autonomy. There is no word for rape in Urdu: the legal term for rape, zina bil jabr, is not used outside court proceedings (Zia, 
1994:18). In common parlance, rape is referred to as a loss of honour (izzat), which is determined by women and their behaviour but belongs to family or collectivity. The Zina Ordinance codified into state law what was already a norm in many parts of the country where tribal jirgas or powerful local figures mete out punishment without the involvement of courts and police for transgressions such as elopement. The Zina Ordinance elevates izzat or honour that resides in the conduct of women to a basic principle of the state.

Studies of women's prisons indicate that women held in custody or imprisoned under Hudood offenses were overwhelmingly poor women from rural areas (Asia Watch and the Women's Rights Project, 1992), and the large majority of women in Pakistani jails are there for alleged violations of this particular set of laws. Prior to the Hudood Ordinances, fewer than one hundred women were serving sentences in Pakistani jails. By the end of the Zia-ul-Haq period there were 4500 women in prisons, 80 percent of them serving sentences for zina (Shaheed and Mumtaz, 1989). In her study of women imprisoned for zina, Shahnaz Khan (2006) found that those in jail were typically women who had eloped or simply run away from their parents, women whose husbands or former husbands sought to exercise control over them through charges of zina, ${ }^{4}$ or people who had provided shelter or assistance to runaways. Khan writes that the zina law has become a tool for rounding up errant women: "In a sense the zina laws are used to sweep clean the streets of women, particularly those who are poor, unwanted and rebellious" (2006:77).

\footnotetext{
${ }^{4}$ A common scenario is that of a woman who remarries after divorce and is then accused of committing zina with her new husband by her former husband who claims that he never officially registered the divorce.
} 
Surveys undertaken after Zia-ul-Haq's decade in power indicate that roughly onehalf to three quarters of women experienced abuse in custody, usually sexual abuse and rape by police or guards (Asia Watch and the Women's Rights Project, 1992; Jahangir and Jilani, 1990; Mehdi, 1990). Thus, the legal changes of this period made it virtually impossible for women to file complaints of rape with police and courts and increased women's chances of being jailed and subjected to violence by the state through floggings meted out as punishment for zina and through abuse by police while in custody. Women accused of zina often spend years in jail awaiting trial. Their children may be jailed with them or left without appropriate guardians. In some cases women do not know what has happened to their children when they are released from prison and they face enormous difficulties rebuilding their lives (Khan, 2006).

Another legislative attack on women, the Law of Evidence, was proposed in 1982 and became law in 1984. This law set the testimony of two male witnesses, or one man and two women, as requirements for legal proof. This law not only reduced the legal status of women's testimony in relation to that of men but also meant that if only women were witnesses, nothing could be proved. Originally, it was proposed that this would cover all laws outside Hudood. In the end, after protests by women's groups, it was limited to "financial and future obligations." The implication remained that women have a lesser status in the public world of legal contracts and financial transactions.

The Qisas and Diyat laws were proposed in 1980 and adopted by the Majlis-iShoora in 1984. These laws specified provisions for retribution or the payment of blood money in cases of murder or bodily injury. The amount of blood money to be paid for the murder or injury of a woman was to be half that of a man. Again, women were 
considered to be less reliable as witnesses. In cases of qisas (retribution), the testimony of women and non-Muslims was acceptable only in tazir cases. In addition, these laws contained clauses that would have made abortion illegal under any circumstances. Women's groups found the assertion that a woman's life was worth half a man's objectionable, though consistent with the regime's other efforts to displace women from the realm of economic activity. But this was only part of the fundamental transformation of concepts of crime, law and justice presented by the qisas and diyat laws. The laws encouraged a view of crime, including murder, as individuals wronged by other individuals, thus weakening the notion of the state; and they promoted the idea that people have a monetary value that, like their honour, belongs to their kin. As such, qisas and diyat have involved the privatization of crime and monetization of justice (Human Rights Watch, 1999:42). Qisas and diyat also directly encouraged feelings such as retribution and revenge that had a heightened currency in the Islamist regime's affective economy of honour/dishonour. They increased the leeway for discretion within the judicial system in determining whether to prosecute serious offences, and complicated the prosecution of crimes occurring within families, reducing the influence of courts and state law within the family. ${ }^{5}$

The Zia-ul-Haq regime sought to bring in an overarching Shariah Law administered by the ulama as opposed to shariah interpreted as family law by the secular

\footnotetext{
${ }^{5}$ For example, in cases of murder, blood money would be paid to the heir of the victim, resulting in an absurd form of justice in the case of murder within families, the most common form of which is the murder of a woman by a male relative. In a privatized judicial system, victims could also be pressured to abandon legal cases, and those wealthy enough to pay blood money were given a near "license" to commit murder. The many ways that qisas and diyat reduced the legal prosecution of violent crimes are documented in studies by Amnesty International (1999) and Human Rights Watch (1999).
} 
state. After the regime began to introduce Islamic laws in 1979 , there were rumours that the Muslim Family Laws Ordinance would be repealed and the leader of the PNA claimed he had assurances from Zia-ul-Haq that he would change these laws (Carroll, 1982: 61; Mumtaz and Shaheed, 1987:74). As an indication of the importance they gave to family laws, both the Ayub Khan and Bhutto governments had protected the Family Laws Ordinance in their constitutions of 1962 and 1973 respectively. The major constitutional change needed to overturn the family laws required more time to formulate than earlier Islamization measures such as Hudood, the Law of Evidence, Zakat and Ushr and Qisas and Diyat. A Shariat Bill that would require all laws to be in agreement with Hanafi Sunni law, and that would prevent appeals of shariat court judgments to regular courts, was introduced in the Senate by members of the Jamaat-i-Islami shortly after the 1985 elections. This would have paved the way for the repeal of the Muslim Family Laws Ordinance. The Pakistan Muslim League countered with a version of the bill that would grant less power to the ulama than the one proposed by the Jamaat-i-Islami, and that would protect economic and financial matters from the purview of shariat courts (Baxter, 1991:38). While the bill stalled in parliament, Zia-ul-Haq became more frustrated and, after dismissing the government in 1988, he declared Shariat Law by presidential ordinance. With Zia-ul-Haq's death shortly thereafter and the election of a PPP government, the ordinance was not endorsed into law. ${ }^{6}$

In addition to intimidating women in public places, legal reforms were used to dismantle citizenship rights for women. The new laws contributed to creating an

\footnotetext{
${ }^{6}$ This was not the end of the issue, however; Zia-ul-Haq's ideological successor, Nawaz Sharif, made further attempts to introduce shariat law during his two terms as Prime Minister during the 1990s.
} 
increasingly hostile and violent climate for women, and particularly poorer women against whom the laws were applied most often. Legal changes of Islamization questioned women's worth, their intellectual competence and their autonomous control over their bodies and their lives, marking an end to the previously symbiotic relationship between women's groups seeking citizenship rights and a state positioning itself as protector of women.

\section{The Women's Action Forum (WAF)}

While the Movement for the Restoration of Democracy came into being in 1981 to demand elections and an end to martial law, another organization emerged during the same year specifically focused on challenging Islamization. It was an organization of women who saw themselves as the target of Islamic laws and directives and it represented precisely those women Islamists most disliked: urban middle and upper class women who work outside the home, engage in social welfare work, lobby the state for citizenship rights and gender equality, and work to expand the state's involvement in regulating the family and in social policy. Many commentaries on WAF point out that its relevance did not extend beyond urban women; that it was focused on laws that do not impact a large proportion of Pakistani women because the writ of the Pakistani state only extends so far, and because most women are not able to pursue their rights in courts. While there is truth in these assertions, I focus on the significance of WAF for what it reveals about the political order that preceded Zia-ul-Haq, as well as Zia-ul-Haq's political project, and the place of women in both.

The Women's Action Forum was formed in Karachi in 1981 as an umbrella organization of groups and individuals protesting the government's various Islamization 
measures affecting women. WAF originally came together in reaction to the first sentences that were delivered under the Zina Ordinance, helping to arrange legal appeals and paying for space in newspapers to publicize the content and ramifications of the Hudood Ordinances. WAF quickly expanded its activities to campaigning against the potential repeal of the Family Laws Ordinance, as well as against chadar directives, police abuse of women in custody, restrictions on women's participation in sports, plans for a separate women's university, and the ban on cultural activities in educational institutions (Mumtaz and Shaheed, 1987:74, 105). Within a few months, Lahore, Islamabad and Peshawar also had WAF chapters. While the Hudood Ordinances were promulgated before WAF was formed, the organization became involved in protracted debates with various ulama and supporters of the regime in an effort to stop the proposed Law of Evidence and the Qisas and Diyat laws. A 1983 demonstration against the Law of Evidence during which about 300 women protesters were chased by a larger number of police down Lahore's main boulevard, beaten with batons, tear-gassed, and carried off in police vans, helped WAF achieve a high media profile for publicly opposing the regime and defying martial law.

Unlike APWA, WAF was prepared to engage in demonstrations, protests and criticism of the regime. WAF arranged for talks by ulama who disagreed with the government's interpretations of Islamic law, distributed cassettes of these talks, and criticized the actions of the regime through press releases, posters, pamphlets, workshops, seminars, panel discussions, pickets and demonstrations. Even APWA, despite its distaste for political activism, felt the need to respond to the newly emerging gender order. In 1982 Rana Liaquat Ali, APWA's founder, wrote to Zia-ul-Haq requesting a dialogue with 
him about the role and status of women. Observing that women had "become the talk of the day," she stated that although APWA's activities had always been confined to community development and social services, there was a need to re-orient their approach given that "women stand threatened and are being considered as mere chattel, as undignified subordinates in a male dominated society" (Dawn, May 12, 1982).

WAF members describe the movement as a reactive one whose activities were shaped by the actions of the regime. More broadly, however, the 1980s were a period of considerable organizing and activism by women and debate about women. Other women's groups also multiplied during this period, including various NGOs devoted to women's issues and women's wings of political parties, including the Jamaat-i-Islami. In 1982 the Sindhiani Tehrik was formed as a women's wing of the Sindhi nationalist Awami Party, and it became the largest women's organization in the country. It functioned in rural towns and villages of Sindh and addressed gender and class issues along with Sindhi nationalism.

WAF was composed primarily of middle and upper class women in the major metropolitan centres in Pakistan, although it also attracted some women from urban working class backgrounds. The class composition of WAF reflects women who felt most strongly impacted or interpellated by the discourse of Islamization. Most of the women were professionals such as journalists, teachers and professors, lawyers, and community development workers. While it was somewhat homogeneous in class and social background, there was substantial ideological diversity within WAF. For example, among the WAF members I interviewed (Appendix A), there were women from socialist groups (Tehrik-i-Khawateen, Democratic Women's Association), trade unions, liberal 
groups (Punjab Women Lawyers' Association, APWA, Human Rights Commission of Pakistan) and more conservative political parties (Muslim League, Tehrik-i-Istaqlal). One interview participant (\#18) worked as a high level bureaucrat in Zia-ul-Haq's government and was supportive of the project of Islamization in theory, although she opposed aspects of its implementation and the increased platform it provided to "mullahs." Some women were part of NGOs that focused on women's issues, including some that were formed during the 1970s (Shirkat Gah, Aurat) and others that came into being during the Zia-ulHaq period (ASR, Simorgh).

Women's activism had some effect on state action during this period. Some aspects of the program of Islamization were not carried through as a result of public protests led predominantly by women's groups. In the wake of the 1983 demonstration there were numerous additional demonstrations although police exercised more restraint after the negative publicity resulting from their actions and the popular attention the police brutality had drawn to WAF. The government also established a women's working group to advise the government on development policy, a National Commission on the Status of Women, and other measures that Said Khan (1988) argues were largely cosmetic but were in part responses to women's growing activism and the national and international profile WAF was developing. There was considerable direct opposition to WAF by supporters of the regime:

[WAF] was denounced in the pulpit, in the masjid [mosque], Dr. Israr Ahmad spoke against it at great length, when we came out on the streets those of us who were married were told that our nikahs [marriages] had been dissolved because we had come out publicly and then we were consequently living in sin with our husbands. Certainly there were demonstrations against us by name, there were poster campaigns against us (Interview 10). 
WAF meetings were monitored by state and police intelligence (Mumtaz and Shaheed, 1987:140). Like the MRD, WAF called for a boycott of Zia-ul-Haq's 1984 referendum (Mumtaz, 1991:106). WAF members I interviewed felt that they were having an impact on Zia-ul-Haq, observing that PTV was careful to depict "a lot of imagery of women going and voting" (Interview 11) during the referendum, and that, while campaigning for the referendum, “There wasn't a stop that [Zia-ul-Haq] didn't go to and said 'Don't listen to these two hundred women"" (Interview 4).

Zia-ul-Haq appointed 16 women to his Majlis-i-Shoora with nearly 300 members. In addition to being presented with chadars, the Majlis women were provided with instructional material on the difference between the type of womanhood sanctioned by the regime and the type represented by WAF. The interview participant who worked as a bureaucrat involved in implementing the government's policies gave me a copy of a cartoon drawing that she said was given to the Majlis women after they completed a training course to prepare them for their duties. The cartoon depicts the difference between "Enlightened Muslim Women" and proponents of "Women's Lib." In the cartoon, the latter are depicted with angry faces and walking toward the "edge of a precipice." Below is a raging sea upon which two crying children and a panicked man try to keep from drowning in a tiny boat called "Family." The Enlightened Muslim Women in contrast are marching to "the heights of glory" with serene expressions and accompanied by smiling men and children. The Women's Lib Women carry placards demanding their rights within Islam but rejecting their obligations; demanding child care, legal abortion, payment for housework, gender equality and identical roles for men and women in national development. The Enlightened Women carry placards saying the best 
place for a woman is in the home and she should only go out to work if necessary, caring for children is a woman's key role, men are the guardians of women, women should practice hijab or modest dress in public, and women have the right to education, property and to vote. The placards of the Enlightened Women appear to be generally in line with the Jamaat-i-Islami ideology, which endorses women's right to vote, own property and receive education. Most of the Enlightened Women wear long cloaks and headscarves while the Women's Lib Women wear mini skirts and sleeveless shirts (apart from one in a sari), clearly suggesting Islamic versus westernized women, though both portrayals poorly resemble the actual clothing practices of Pakistani women.

Despite the training they received, the Majlis-i-Shoora women were not fully convinced of the stand they were to take against "Women's Lib" women. The day after the 1983 Law of Evidence protest when women were beaten by police, one male and three female members of the Majlis rose to complain about the treatment of the women and to request an inquiry into the police action. Their comments underscore the contradictions of a regime that spoke of honour but in fact treated women with violence. Majlis member Sabiha Shakil said "We have been branding the old governments as wrong doers and calling them names. But in the present regime which is called a gentle regime, women have suffered excesses under this regime to the extreme."7 Another member, Mahmuda Sultana, ignoring instructions from the Chairman not to speak, was inspired to read a verse that appears to be a thinly veiled critique of the government's discourse on the honour of women and the sanctity of chadar and chardiwari:

Oh the wine bearer, ${ }^{8}$ how inhospitable our fate

\footnotetext{
7 The Federal Council (Majlis-i-Shoora) Debates, February 13, 1983.

8 "The wine bearer" is a metaphor for a sympathetic listener or host.
} 
Oh the wine bearer, ours is not the garden, nor the flower, nor the nest

Oh the wine bearer, is there a place of peace and safety for us?

Others spoke against the women protesters, including the appointed Minister of Interior and Muhammad Zafar Ahmad Ansari. ${ }^{9}$ They lamented that the demonstrators did not understand Nizam-e-Islam (the rule of Islam), and claimed that "our women" need to understand what the Quran says.

Saigol (1997) refers to the use of "our women" as a "differentiating factor" that was common in the discourse of nineteenth century Muslim reformers who used it to demarcate a distinct Muslim community in India. Though it never entirely went out of fashion, its reappearance and prominence in the discourse of the PNA, and then in the speech of Zia-ul-Haq and other members of his regime, is significant in the context of a new political project. It is linked to the other discursive refrain of calling women who work, and particularly WAF women, "westernized." One participant who had been active in APWA for decades said she did not remember being called "westernized" before Ziaul-Haq. As "westernized women," they were seen as a threat to "our women" in the process of transitioning from a nation of Muslims to an Islamic state:

The other insult that people like myself suffered was a general blanket kind of condemnation of women who talk and think like us, and who consider ourselves to be believing Muslims...I got one or two nasty letters personally, you know, that I'm a threat to the sort of purity of women and why don't I emigrate. (Interview 14)

\footnotetext{
${ }^{9}$ Ansari is known for his role heading a commission appointed by Zia-ul-Haq to examine recommendations for an Islamic system of government. The commission's report expressed the view that a woman could not be head of state and that, to avoid interfering with their child care duties, only women over 50 could participate in politics provided they had written permission from their husbands.
} 
WAF participants came to represent a type of woman who was a threat to the family. "WAF types" were commonly portrayed as frustrated women, potentially lesbians, who neglect their homes and families, smoke, wear their hair short, and get divorces.

Despite its opposition to particular Islamization policies, in responding to Islamization, WAF itself became part of a larger process of extending scripturalist notions of Islam, of normalizing pious practice and of advancing the notion of an abstract Muslim self. During the 1980s WAF often challenged the regime more for the types of Islamic interpretations employed than for the overall project of Islamizing women. A major approach within WAF was to advocate the view that if interpreted properly Islam gives women rights, and to put forth alternative liberal interpretations of Islam. Several women I interviewed mentioned that during Zia-ul-Haq's rule they read the Quran for the first time. Knowledge of scripture and different interpretations of scripture by different groups of ulama expanded. WAF invited members of the ulama to public meetings where they presented alternative interpretations of women's rights in Islam to those coming from the Council of Islamic Ideology. Some in WAF adopted pious practices as well. One WAF member described returning from a workshop in the countryside during the month of Ramadan, and meeting some WAF friends who were fasting: "I had never known them to be Islamic. I asked them why [they were fasting] and they said they wanted to be one with the people. I had just come from the people and nobody was talking about fasting and few were doing it" (Interview 4).

WAF's engagement in deliberations over scripture resembles the type of public debate that Hirschkind (2001) describes as characteristic of an "Islamic counterpublic." It is based on the popularization of knowledge of the content of Islamic texts through 
"cassette sermons" and other forms of mass media, which leads to debates about proper interpretation. Popular knowledge of Islamic texts does not close debate, but provides a platform for it. Individuals express opposing views using reasoning and argument as in a liberal public, though "lines of argument pivot precisely on the proper interpretation of [religious] sources" (Hirschkind, 2001:9).

Newspapers at the time were full of articles on Islam and women's rights, including various perspectives on what Islam "says" regarding women's rights to give evidence and women's rights to divorce, or debating women's participation in sports. The press also arranged debates between WAF and orthodox or Islamist women. The women I interviewed commented that the two groups were often putting forth essentially the same perspectives on many issues regarding "women's rights" though Islamist women would also emphasize observance of purdah. Some within WAF argued that it was necessary to situate women's politics within a discourse of women's rights as granted within Islam in order not to be perceived as being against Islam and not to allow the government to shape and define an unopposed discourse on Islam. Throughout the 1980s, the issue of whether or not to identify as a secular organization was a contentious one in WAF. It was difficult to use the term "secular" at all during Zia-ul-Haq's rule, particularly in its Urdu translation "la diniyat," which means without religiosity or faith. ${ }^{10}$ Also, the basis within Islam of many of the government's measures was questionable (such as stoning as an Islamic punishment, women's lesser worth, a woman's testimony

\footnotetext{
${ }^{10}$ There is no word in Urdu for the conventional meaning of secular as separation of church and state. "La diniyat" is a controversial translation favoured particularly by opponents of secularism.
} 
being equal to half a man's, and abortion as prohibited), though others were less scripturally ambiguous (such as injunctions prescribing 100 lashes for adultery).

WAF in fact did declare itself to be a secular organization in 1991 after years of debate. However, prior to this, within the "rights in Islam" approach, there was an implied acceptance of scripturalism as the sine qua non of Islam. Some within WAF held a contrasting view that while religion was an important component of many women's lives, the disciplinary piety implicit in the approach of adopting an Islamic framework for activism was not. For example, an older WAF member commented:

I've been working since I was a very young girl. I have never come across peasants, working class women, lower middle class women, who would ever ask me 'have you said your prayers?' or 'why don't you cover your head?' No one's ever asked. ...So this question [of what Islam allows] is raised by those in power to make the people conscious of women who are working, and that they are not working the way Islam allows them to work. (Interview 15)

These comments draw attention to the elite origin of both Islamization and the resistance to it. WAF was often accused of betraying an upper class perspective in protesting restrictions on women's sports, for example, but Islamists reveal a similar concern with elite class and gender formation in their focus on women's sports. As suggested in one letter to the editor, ${ }^{11}$ the religious lobby was not concerned with girls' or women's athleticism if it involved sweeping the streets, walking for miles because there is no adequate public transport, climbing trees to cut firewood, working in the fields, or hauling water or any number of goods long distances on their shoulders and heads. When Zia-ul-Haq announced the Shariah Ordinance after dismissing parliament in 1988, one member of the Senate noted its effectiveness for creating positions within the state for the

11 "Games without women" Muslim, December 5, 1982. 
ulama, but questioned its relevance for the people who were supposed to have demanded it:

The Shariah Ordinance in my view is all up in the air instead of being down on the ground where the reality is...Many sections of it deal with the induction of Muftis, ${ }^{12}$ appointment of Ulamas to the High Courts. High courts are a long way away, Mr. Chairman, $95 \%$ of the people of this country do not have the means the financial means, the social means to be able to afford justice in the High Courts, $95 \%$ of the people are at the mercy of the junior lower courts and if you take $50 \%$ of the population which is women who do not even have the freedom or the courage to step out of their doors in the villages, leave alone walk into the Supreme Court or High Court and talk to the Ulamas and plead their cases for equal rights or the rights given to them by Islam. So, what does the Shariah Ordinance do? ${ }^{13}$

WAF was frequently criticized nevertheless as an elite organization. Several women I interviewed acknowledged the class bias and stressed that, in protesting the actions of the regime, there was a concern not to endanger women from poorer classes who could experience more state violence as a result of challenging martial law. For example, one WAF member said:

It had to be women who were able, because of their background, to withstand that pressure [of a military government], who had their own particular lobbies behind them. For instance, being a lawyer, all the judges were behind me when I went to jail, and they said 'what the hell, how can you put these women in jail?' (Interview 12) ${ }^{14}$

Yet at this time women belonging to the Sindhiani Tehrik, including peasant women, were themselves "courting arrest" on a daily basis as a political strategy (Mumtaz, 1991:107). The women I interviewed who were factory workers stressed different reasons for the lower involvement of working class women in WAF, including concerns about

${ }^{12}$ Interpreters of Shariat.

${ }^{13}$ Mr. Javed Jabbar, Senate of Pakistan, August 4, 1988.

${ }^{14}$ In fact, another WAF member who was not a lawyer told me that the lawyers within WAF played a key role in convincing more reluctant members of the Lahore chapter to do the first 1983 demonstration. 
encountering women who were from the families of factory owners, a tendency within WAF to function in English, insufficient attention to issues of foremost concern to factory women such as sexual harassment in the workplace, and different modalities of political action between working class and upper class women. ${ }^{15}$

In terms of women from poorer backgrounds or rural women, their primary concerns were not those articulated by WAF. This is not to say that the discriminatory laws that WAF focused on did not affect them, but their relationship with the state was not as a protector of their rights. Most women do not have the resources or knowledge of laws to benefit from legal rights, and laws designed to protect women's rights are often not enforced. One WAF participant attributed the group's legalism to the influence of lawyers within the organization: "Most of the time the focus was on discriminatory laws. Partly also as a result of an enormous amount of influence of liberal middle class lawyers on the movement. Early on in the movement the lawyers became dominant and focused on laws" (Interview 1). More broadly, WAF's focus on laws may be seen as a reflection of the affiliation of upper and middle class professional women with a particular political order founded on law.

Some men on the left leveled their own moral critique of WAF, labeling them elitist, bourgeois, and westernized (Ali, 1988). The accusations could be applied to many men on the left as well, but they were directed at women for the sin of abandoning "the people" for women's issues and perhaps also for stepping outside familial roles. Women in WAF spoke about a surprising lack of support from men who opposed Zia-ul-Haq but

\footnotetext{
${ }^{15}$ For example, one of the factory workers interviewed mentioned that participation in WAF's pre-planned demonstrations required cars, telephones and a certain "sense of time." (Interview 16)
} 
did not support the autonomous organization of women against the regime, arguing that women in WAF should concentrate on bringing an end to the martial law and not focus specifically on women's issues. There was a particular concern within WAF though that once legal changes were instituted they would never be reversed. In larger terms, and despite WAF's avoidance of the word "secularism," the battle between state law and shariat law during Zia-ul-Haq's time was fought largely between the groups of women involved in WAF on the one hand, and Zia-ul-Haq and his supporters on the other. Women groups understood that chadar and chardiwari discourse was not merely the inconsequential ramblings of a dictator, but a new motif of rule that symbolized a profound shift in the political order that would outlive the end of martial law.

While a primary focus on women was not seen as legitimate by many men who opposed the regime, the ulama and religious scholars were fully prepared to talk about women. In fact, pointing out the contradictions of liberalism, and the dogmatism of the left, some women found in men of the religious right a debating partner that they had never had among other men in Pakistani politics:

At times we felt almost that we could in fact have a dialogue with educated religious scholars, highly educated men, because they sort of much more understood that you were representing a position and they were representing a position. You could actually debate with them. It was the men of the left, progressive men, that we found the most surprising. Actually the most fundamentalist group were the men of the left and the liberal men. (Interview 1)

Her comments illustrate an interesting feature observed by some authors in the context of earlier stages of Muslim reform. In chapter three, I referred to arguments suggesting that reformist Islam draws no distinction between men and women as moral agents (Metcalf, 1990), or that once they are made moral, women have a platform to challenge orthodoxy (Devji, 2008). Their supposed equal citizenship never granted women such a platform in 
socialist or liberal politics. Piety politics in fact provide a large space for women's involvement, as was the case with the piety movements protesting colonial rule in the 1920s and 30s, which, as I mentioned in Chapter Two, involved many more women than the social reform-oriented women's organizations of the time. In Karachi, however, WAF was able to make more supportive connections with men on the left through the MRD and a broad-based Sindhi nationalist struggle, which is not surprising given the important role of women in nationalist movements.

\section{Impact of the Zia-ul-Haq Era}

The campaign of the regime and its supporters against working women did not actually result in decreased employment for women (Korson and Maskiell, 1985; Rouse, 1998:146-47). Islamization did not result in an enforced seclusion of women either, although women's negotiation of public spaces became more problematic. In interviews conducted several years after the end of Zia-ul-Haq's rule, the women I spoke to emphasized two major consequences of the Zia-ul-Haq period for women: depoliticization and an overall decline in women's activism after a period of intense activity during the 1980s; and an increase in violence and new forms of violence against women. I discuss each of these outcomes below.

\section{Depoliticization}

Prior to the 1980s, the predominant mode of women's activism was social work and social welfare, a politics that was aligned with nation-building. During the $1980 \mathrm{~s}$, it was increasingly replaced by a development framework that sought to align women's lives with the market and the cash economy (Rouse, 1997). Rather than a relationship 
with national government, women's activism became partnered with NGOs and international funding agencies. This was related to the influx of money and funding from international agencies during the 1980 s and the decline of state involvement in social welfare, along with the Islamization of universities which forced many researchers to locate themselves in other institutional settings. With the new interest in Pakistan after 1979, foreign donor agencies began "pouring money into the country" (Interview 1). USAID and other international agencies that had left the country at the end of the Ayub Khan era returned to Pakistan in the context of the Afghanistan war and became involved in numerous development projects within the country more broadly. Money from donor agencies was used by members of WAF to fund existing NGOs or to establish new ones. Those not directly associated with NGOs began to conduct their work or activism in a context dominated by NGOs. This influx of funds provided resources for a considerable amount of basic research on women that had never taken place before. However, many women I interviewed were not entirely at ease with this change and reflected on the negative aspects of the transfer of women's organizing from political activism to NGOs.

One WAF member explained that many women originally hoped that the NGOs would provide research to support activism, but that in practice they drew women away from activism and promoted a culture that was inimical to politics as they knew it:

Instead of activists coming into WAF from the NGOs, the NGOs started taking people from WAF, and turning them into paid activists. So that they became workers, they became functionaries, bureaucrats, in NGOs. I mean, you know, they developed the habits that you develop in work of not having political anger, or not acting out of feeling, emotion, but you know, doing something just as work, as a job. And that really damaged WAF, very, very seriously. (Interview 1)

The emergence of NGOs and their role in dissipating political activism was mentioned by several women I interviewed, and is a point also made by Nighat Said Khan (2000). 
Despite all of the opposition they had mounted to the Islamic military regime, in their descriptions of changes to politics and activism several women mentioned a process of "depoliticization" happening over the course of the 1980s, as if Zia-ul-Haq's exhortations to lead a simple life, doing one's job and staying out of politics, had a lasting effect.

While international funding agencies insisted that all projects have a "women and development" component, they often ignored the gender politics of the Zia-ul-Haq regime or of the Mujahideen leadership. For example, many funding sources mandated "gender sensitivity training" in their projects, backing a regime that portrayed working women as immoral while at the same time educating individual Pakistanis to correct their supposed cultural/Islamic gender biases. The discourse of nationalist women's politics emphasized citizenship rights and women's role in national development. In the new regime, the moral component emphasized "human rights."

Human rights organizations were formed in Pakistan during the 1980s, most importantly the Human Rights Commission of Pakistan. Human rights-based discourse and politics became a prominent feature of NGOs and international aid organizations at this time as well. Human rights activism has done much to document and protest the impact of the exercise of power on individual lives, and it is difficult to contest the value of this work in and of itself. However, despite the fact that human rights discourse and activism typically disclaim affiliation with particular political projects, human rights is a form of politics that shapes moral-political struggles, agendas and landscapes in particular ways (Brown, 2004:453). Human rights discourse posits basic, inalienable rights of the individual that apply universally. To the extent that it takes the place of a politics of citizenship rights or collective rights, a politics of human rights - of freedom 
from rather than rights to - may harmonize with political regimes that place increased responsibility on individuals to manage their own needs without resort to claims on state institutions or engagement in politics (Ibid: 454-457). At the same time, human rights discourse links to international moral regimes in which certain countries are configured as "successful" liberal democracies and assume the moral authority and legitimized pedagogical agency that this claim entails. Human rights discourse focuses on the abuse of rights and less on how rights abuses are organized politically. For example, one WAF member characterized the tendency of human rights discourse to separate "rights" from their political, social and economic context:

We [western countries] can't have your [Pakistan's] goods in our market because you use child labour. No question about why you have to use child labour because your child will die and starve if he doesn't earn because of the terrible, unjust distribution of wealth. (Interview 1)

In the process, human rights discourse tends to lay the blame for human rights abuses at the door of culture, religion, and tradition - a defect in attitudes and customs to be corrected through pedagogical techniques and training. Such discourse coincides with the process of depoliticization described by Wendy Brown, and cited in the introduction to this work, as one of "construing inequality, subordination, marginalization, and social conflict, all of which require political analysis and political solutions, as personal and individual on the one hand, or as natural, religious, or cultural on the other" (2006b:15).

An example of this tendency to depoliticize is evident in a 1999 Human Rights Watch report on violence against women in Pakistan. The report ably documents patterns of violence against women; notes an apparent increasing prevalence - which I discuss further in the next section - in crimes such as the murder of women by family members in the name of "honour"; and accurately notes the role of laws introduced during the Zia- 
ul-Haq era - particularly the zina, qisas and diyat laws - in contributing to the violence and to the lack of legal sanction for crimes such as "honour killing." However, the report also identifies culture, religion and the "structure of the family" as centrally responsible for the violence (Human Rights Watch, 1999:29). I suggest that legal changes, and patterns and forms of violence, cannot simply be situated within the context of religion and culture, but need to be viewed as strands of a larger politics that encouraged the proliferation of guns; encouraged vigilantism; defined justice as retribution; weakened national institutions, thereby also weakening oversight and accountability within institutions such as courts and police; placed a premium on the appearance of propriety by governing through an obsession with right and wrong conduct and the public performance of piety; emphasized the immorality of women; and encouraged the masculinization of public space. An understanding of how these processes relate to an emerging political order provides a crucial context for understanding changing patterns of violence and changing legal concepts and practices.

The general thrust of development projects carried out by NGOs resembled Ziaul-Haq's project of political decentralization, privatization, and an approach that positions women as consumers and housewives, not producers. Rouse writes:

Never was there any question of tackling the more substantive issue of women's participation in productive agriculture or the denial of both wages and tenancy rights for such work. ...the direction taken led to a form of paternalistic consciousness-raising, and reinforcement of the idea of appropriate paid employment as being outside the productive sector, bringing women into the cash economy so as to extend markets and their purchasing power (1997:160).

WAF members from trade unions stressed that factory women's organizations were not able to gain funding from NGOs, participate in large international conferences where knowledge and agendas that are supposedly "by, for and about women" are formulated, 
or network within government and administrative circles where the "ideologies are different" (Interview 16).

Along with the dissipation of women's activism, there was a loss of a language to talk about "the social." One participant described how economistic categories seem to have superceded social ones to the extent that one cannot employ a relational or integrated perspective:

There has been a general tendency to talk more about poor women, poverty, but not the class structures ... Recently I was talking somewhere and I was trying to talk about class and somebody said 'but you're talking out of time' and 'these things no longer exist and now we talk of women working in the formal sector and women working in the informal sector and the factory women.' So this categorization of women by work seems to somehow, I mean it's as if class differences don't exist. ...the economic categories are being given more importance whereas the social class categories are not being given importance. So you're being defined by your work, but you're not being put into an overall framework. And that I find disturbing. (Interview 2)

She attributed these changes to the model of development promoted by international development agencies and the proliferation of NGOs that increasingly set the context in which women's activism occurred.

There was an overall decline in activist politics among men as well. During Ziaul-Haq's rule, the left was considerably weakened. This was in part because of persecution by the regime: left organizations directed efforts toward finding ways for trade unions to survive being banned, as well as helping those facing legal charges, and helping the families of those who were jailed, exiled or in hiding. Beyond this, however, one interview participant who was active in a number of left organizations during the 1970s felt that men did not appear to go "underground" in their activism so much as disperse, unlike women who organized during this period. She observed an increasing tension between women and men on the left, remarked on by others in WAF, and 
observed that many men "went quietly into their own professions and they were much more lost" (Interview 4).

Although WAF was always a small organization of a few hundred women in the major cities in Pakistan that was intended to mobilize a larger network, by the 1990s it had become a much smaller organization with a reduced public presence and ability to attract new members. In addition to the role played by NGOs, WAF members spoke about a broader cultural change characterized by depoliticization, a disaggregation of social life, and a "retreat" from public space that hindered the ability of political movements such as WAF to continue. One participant felt that although women were not "domesticated" in the sense of reduced numbers of women pursuing employment or education, another form of domestication took place - a "conservative trend" of greater emphasis on marriage, consumerism and domestic comfort. Several women observed a greater focus on work, particularly on making money, and either a "pragmatism" or a "cynicism" that stands in contrast to the idealism of former generations. These traits were attributed both to the experience of young people who grew up under dictatorship and martial law, and to the Islamization of education:

[Young people] have become more cynical. Because in the universities, they were not allowed to ask questions. Women were not allowed to smile. Because the Jamaat-i-Islami had taken over the universities. And the effect is that they're different. All they want to do is make money, good money. There's no education in the real sense of the word. (Interview 15)

WAF members involved in teaching had much to say about the literalism and rote learning promoted in schools during the Zia-ul-Haq period (to a greater extent than in the past), themes that are raised by Saigol (1995) as well. In discussing the "depoliticization" they observed during the 1980s and 1990s, WAF members I interviewed consistently 
spoke about a dulling of emotions and an adaptation to tedium. While Zia-ul-Haq explicitly put restrictions on political activity, piety was a technique that was much more effective for depoliticization, including emotional evenness and adopting an inward perspective focused on religious observance and "doing one's job."

One WAF member talked about how the categories with which women had thought about, lived and enacted politics were no longer valid:

Where do you get your activism in the world today? Maybe environmental issues, which until recently a lot of people didn't think they were relevant to the Third World. So there's been tremendous depoliticization of society, much more cynicism among young people, much less feeling that action can bring about transformation. ... Now we're not being able to define it, you know, what are you talking about? I think democracy needs a redefinition, party politics needs redefinition. The global economic system needs redefinition... you cannot take the old sort of almost irrelevant outdated concepts and try and breathe life into them. (Interview 10)

Her comments are indicative of the extent to which the political landscape had changed during the 1980s. The Islamization of education, combined with a shift from a statecentred welfare and community development policy to NGOs and the system of zakat distribution discussed in Chapter Five, contributed to depoliticization. Another contributor was the banning of trade unions; the new culture of NGOs was not accessible to labour leadership or particularly open to the concerns of labour. Piety fostered through media content, government directives to schools and workplaces, the empowerment of local religious leadership, and even public debates that WAF participated in, also shifted the focus away from "politics." Women who had opposed the political project of Islamization were left asking themselves "What does a new politics look like?" 
Many reports indicate that the overall incidence of violence against women increased under Zia-ul-Haq (Rouse, 1992:101; Said Khan, 1988:11), and has continued to increase in the years after Zia-ul-Haq's rule (Amnesty International, 1999:2). The initial incidents of conservative men or maulvis slapping women on the streets for the way they were dressed rapidly progressed into new forms of violence against women. An overall increase in violence was linked to a regime that encouraged vigilantism and gun ownership, and that appeared to relinquish any discursive claim to a state monopoly on the legitimate use of force. During the 1980s guns proliferated throughout Pakistan, related to the Afghan war. Additionally, Zia-ul-Haq encouraged gun ownership, granting gun licenses to members of the National Assembly and allowing them to personally distribute gun licenses in their localities. Prior to the Zia-ul-Haq period, Pakistan had never had such an armed population (Rouse, 1997:157).

The weakening of ideas of citizenship, individuation, and contractual equality, evident in new laws such as Qisas and Diyat and the Law of Evidence, also became apparent in the increase in violence linked to group, family or community honour. Violence against women became linked to political or personal vendettas among groups of men, or by employers or landlords against workers or tenants:

Another iniquitous consequence of locating honour in women's bodies is that women become pawns in the game of revenge. Since a man's honour resides in the bodies of his female relatives...her 'izzat' is irrevocably lost even if she was raped. Rape becomes a very viable form of revenge (Simorgh Collective and Shazreh Hussein, 1990:27).

Retaliation by men against men was increasingly pursued through rape and other forms of sexual violence against the bodies of the men's female relatives, aided by the virtual legal elimination of rape as a crime from Pakistan's penal codes. 
In 1984, an incident occurred that was related to a vendetta but involved a new form of violence against women which shocked Pakistanis. It took place in the town of Nawabpur in Punjab. Men belonging to a landed family were upset about the relationship between a young woman in their family and a man from a poorer household. Men from the woman's family severely beat the man who later died and then seized the man's female relatives and paraded them naked through the streets of the town. This practice then seemed to recur on many subsequent occasions. Rana Liaquat Ali again telegrammed Zia-ul-Haq expressing shock at 3 similar incidents in a one month time span, stating "Such immorality was unheard of even in the early days of Partition" (Dawn, May 5, 1984). Written accounts of partition events and interviews with survivors do, however, contain references to this practice (Menon and Bhasin, 1998:41). To dampen the public outcry, the government moved quickly to pass a law mandating the death penalty for the crime of stripping and parading women. However, this was largely for show. Some of those involved in Nawabpur served short jail terms and the incidents continued. Other reports of parading women nude were frequently raised by MNAs in parliament with information obtained from newspaper reports from various rural localities or small urban centres. In transcripts of assembly debates on these crimes, the Minister of Interior consistently replied that the newspapers were printing sensationalistic and inaccurate reports, a dismissive retort that was virtually unassailable because the survivors of such crimes will not speak. One WAF member recalled asking a civil servant who had also served in the pre-independence ICS (Indian Civil Service) whether this had taken place in the past: "He said it did happen, but it was rare enough to send shock waves through the administration. Nothing like this." 
While Zia-ul-Haq spoke about protecting women's honour continuously, women faced heightened violence in their homes and on the streets. For women there was "no safe place" and "no safe person" (Simorgh collective and Shazreh Hussein, 1990). The women I interviewed spoke repeatedly about a general empowerment of men over women that extended to relationships within families as a result of the erosion of legal rights and increased militarization:

And that atmosphere tends to seep right down to individual level, like husbands in the home start acting differently when the laws are such, more men will accuse their wives of adultery, more fathers accuse their own daughters of adultery, and got them put in zina cases in the jails. (Interview 1)

It kind of encouraged men, these laws encouraged men to vent their anger against women. It probably helped that they can't be taken to task or punished...Men have got guns, and they are free to walk about and a woman's worth is only half by law, thanks to Zia-ul-Haq's law. And the constitution was suspended.

(Interview 14)

Newspapers carried daily reports of women killed by husbands or women killed in supposed gas stove explosions in their homes. Women also faced violence on campuses, including assault, having acid thrown on them at Karachi University, and being prevented from using facilities such as the college canteens ${ }^{16}$ (Dawn, January 25, 1987).

WAF issued statements and press releases expressing the view that rape was becoming increasingly common, and taking place in many state institutions. There were reports of rapes in hospitals, mental institutions and state-run women's shelters. Police stations became especially dangerous places for women. It was virtually impossible for women to approach police with reports of rape; not only could women doing so be charged with adultery, but in many cases women were raped at police stations and often

\footnotetext{
${ }^{16}$ The social atmosphere and the presence of tables and chairs in canteens can occasion the type of "mixed society" so offensive to the IJT.
} 
police would simply refuse to register women's reports of rape ${ }^{17}$ Another crime appearing at this time was the rape of women in their homes during armed robbery (Iqbal, 1990:46). In 1987, WAF started to burn chadars during demonstrations to highlight the contrast between the government's rhetoric about the sanctity and honour of the chadar and the actual experience of women. The first chadar-burning demonstration took place in protest over the abduction, rape, torture and murder of two young women and the murder of their father. In 1989, an organization called WAR (War Against Rape) emerged out of WAF in Karachi to begin documenting incidents of rape and sexual violence, to publicize the problem, to try to change police behaviour and to provide assistance for victims.

Without passing any laws overtly prescribing and proscribing gendered public space, the government was nevertheless able to masculinize public space, leading to "the virtual disappearance of women from urban public spaces except for a few privileged venues which were largely only available to women from the upper and upper middle class" (Rouse, 1997:157). Violence proliferated in the context of a militarized state, with an armed population, and with an investment in the moral horizon of chadar and chardiwari emphasizing male honour and a heightened bifurcation of womanhood into the categories of prostitute and chaste wife/mother. People came to feel increasingly helpless at the extent of the brutality, and often ashamed and therefore silenced by the dishonour, encouraging further retreat and isolation. A political order that places a premium on honour/dishonour encourages another type of emotion in addition to shame:

${ }^{17}$ WAF Lahore newsletter, September 14, 1989. 
a desire for vengeance, which when acted upon often appears incommensurate or lacking specific context and motive.

The reasons for increasing levels of violence at this time are multifaceted. They relate to media campaigns promoting the de-feminization of the public sphere and encouraging vigilantism. They relate in part to laws that promoted retribution and vengeance. Citizenship rights were also undermined by the placing of the constitution in abeyance, the requirement that judges swear allegiance to martial law, and the introduction of parallel judicial systems including military and shariat courts. Judicial pronouncements began to reflect confusion regarding whether women's status in law was that of citizens or of daughters who should obey their parents (Jamal, 2006); as well as confusion regarding whether to base their rulings on constitutional provisions or their own interpretations of custom or shariat. The devolution of administration, described in Chapter Five, that directed affiliations to neighbourhood, family, and local religious leadership, may have contributed to an increased salience of gender regimes emphasizing the equation of women with community or family honour. However, violence related to community honour should not simply be seen as linked to "traditional" practices of localized political regimes, whether tribal, feudal or otherwise. Women's sexual virtue had been the bedrock of nation and community since the nineteenth century. A sobering corollary, as Devji (2008:386) points out, is that women's bodies become sites of desecration during periods of radical political and national revisioning. Three such periods have been discussed here, including the partition of India and Pakistan in 1947, the Pakistan army's attempt to suppress the independence movement in East Pakistan in 1971, and Zia-ul-Haq's attempt to “Islamize" Pakistan from 1977-1988. 


\section{Conclusion}

In this chapter I have attempted to demonstrate how, within the process of deconstructing the nation that I talked about more generally in the previous chapter, there was also a process of deconstructing the form of womanhood most closely associated with a national political order. An attack on middle class professional women, who advocated legal rights and equal citizenship, was central to an attack on the moral and spatial organization of life and forms of self associated with the nation. When Zia-ul-Haq asserted the sanctity of chadar and chardiwari as a central platform, this called into question the relatively feminized state of the Bhutto era and the nation that had integrated women into the public. In response, the political project of Islamization met what was arguably its strongest opposition from women; particularly those women it was trying to deconstruct, disaggregate and depoliticize.

The conflict between WAF and the Zia-ul-Haq regime was not merely over a few laws that don't affect most women and a slight erosion of the secular ethos of the state. It was about cultural forms that accompany political arrangements of rule. The women I interviewed vividly expressed what was also evident in secondary accounts and in much of the archival material on the period: the experience of Islamization during the 1980s was a profoundly embodied experience, characterized by a re-patterning of how they spatially interact with their worlds, how they think and speak, what emotions they can experience, how they view their bodies and what they do with them. This is not to say that this was not an enabling moment for some groups of women whose modes of identification and forms of embodiment are less aligned with the public of the nation state and more aligned with emerging political and cultural forms. The investigation of gender 
formation and state formation since the time of Zia-ul-Haq is a topic beyond the scope of the current project. However, based on the current research, I would suggest that such a project would need to bear in mind that Islamization was not a return to a traditional or "authentic" Islam. It was a project of rule that, along with its cultural forms (pietism, militarism, and consumerism among them), was closely associated with an emerging international political, economic and moral order of globalization and neoliberalism. 


\section{Conclusion}

The place of middle class women in government shifted abruptly and drastically in Pakistan soon after the military coup of General Zia-ul-Haq in 1977. As I stated at the outset of this thesis, this is not an original observation, but I have treated it here as an occurrence that is enfolded in practices and processes that are not well taken up in other writing and that is situated at a historical juncture that is profoundly significant. In this thesis, I have located Islamization as a process that is related to state formation, in contrast to more prevalent approaches that treat Islamization as related to the ideological use of Islam, or Islam as a self-contained cultural system. I have attempted to demonstrate that processes of moral reform positing an abstract Muslim subjectivity were characteristic both of the period of social and religious reform among Muslims during the latter half of the nineteenth century in British India, and of the beginnings of processes of state formation in Pakistan during the 1970s and 80s when national political forms and practices were under assault. I have also attempted to demonstrate that intensive and explicit efforts to reform women were characteristic of both periods. I have contextualized the gender content of Islamization in relation to the connection between gender formation and state formation. Throughout the thesis, I have tried to demonstrate the central role of middle class women in advancing processes of political centralization, in promoting national subjectivities, and in extending the reach of government through their involvement in the social. Finally, I have linked the Zia-ul-Haq government's policies, including the attack on middle class women and the project of Islamization, to processes of reforming and responsibilizing the individual, to denationalization, and to a dismantling of social government accompanying neoliberalism. 
Writing on gender and liberal modalities of power has emphasized the political exclusion of women through their relegation to an extra-legal private domain under liberal government. I have suggested that insufficient attention is given to the importance of nineteenth century debates on domesticity in the formative period of liberal government, and, borrowing from the work of Corrigan and Sayer (1985), I suggest that such debates be situated in the context of cultural revolution accompanying state formation. I locate the nineteenth century "woman question" within attempts to remake the culture of women and to constitute a moral subjectivity for women in the process of reshaping domesticity and creating responsible individuals, available to forms of rule based on notions of a moral collective. Reformed religion, with its emphasis on the moral equivalence of rational, ethical subjects, underpinned a changing political order that made women moral and reformed domestic practice, linking home and polity. Following Devji (2008), I refer to this process of making moral and making Muslim as a process of Islamization.

This research also has contributed to an expanding field of research that has questioned whether it is possible to approach the analysis of gender and nation as "discrete domains" (Sinha, 2004:229). Social and political theorizing on gender and nation has attended to issues of what nations do to women and with women (such as deploying women as repositories of culture, symbols of nations, reproducers of the national collective, or constituencies to be mobilized) more than it has attended to the direct political role that middle class women assumed in creating the nation. Among the possible reasons for this is that liberal or social feminism was a different type of politics than "male politics" and one that appeared accommodationist when seen through a 
progressivist lens. In the case of colonial India, middle class women's politics eschewed the competition and partisanship of "male politics"; presented women as an undifferentiated group superseding divisions of caste, class, ethnicity and language; and preferred to shape the social by supporting juridical norms and state regulation of the family, and by shaping national and liberal subjectivity through techniques and practices such as modern education, modern domesticity, health, hygiene, and "family planning."

My objective here has not been to redeem this brand of politics, but to point out that social government was regarded by many as politically powerful, and as linked to an interventionist state and to national sovereignty. Middle class women's social politics, and the overall patterning of gendered practice and gendered space with which they were associated, positioned them at the heart of conflicts over state forms. As Valverde states, the social is a sphere of intervention: "in modern societies there is no invisible social hand" (1991:20), or, as Newton states, "in a nice revision of Adam Smith, the [competitive market] system corrects itself through the 'invisible hand' of woman" (1994:131). Some middle class political movements have asserted, however, that the system should properly correct itself through the eminently "moral" conduct of its members, such as that afforded by pious religious practice, and by strict adherence to "the family" as a site of morality, along with its demarcations of masculine and feminine, public and private, male virility and female honour/chastity. Women's involvement in public life through social government, or through forms of feminist practice and politics, is not seen as a steadying influence, but as a source of corruption and a threat to the family. Many middle class political movements that organize around religion, Islamism among them, mount a defense not of a traditional model of family life - though this may 
be what they claim - but of a family organized around discourses of self-sufficiency, individual responsibility, and modern domestic practice that draw upon variants of reformed religion that foreground the modern, rational, ethical subject.

In colonial India, religious-political movements led by reformist ulama and the Jamaat-i-Islami, opposed Muslim nationalism as a political movement that advanced and strived to organize a social body. Adapting to the changed political context after the creation of Pakistan, their opposition continued through attempts to introduce theological components into state institutions and jurisprudence, through opposition to family law, and through opposition to the All Pakistan Women's Association and its attempts to create national and liberal subjects through social work. Their opposition strengthened during the People's Party government of Zulfiqar Ali Bhutto in the 1970s, which introduced components of state feminism that began to blur gender distinctions, increase the public visibility of women, introduce understandings of the home as a site of production, and support women's participation in the formal economy. Islamist discourse, with its emphasis on the corruption of political leaders, demands for the privatization of economy and polity, and emphasis on restoring honour to women by returning them to the home, managed to draw in a range of political groups and actors opposed to the People's Party government. Islamism as a strongly critical and moralizing discourse was a fulcrum for a coincidence of interests opposed to social government, or to other aspects of Bhutto's rule.

After seizing power, Zia-ul-Haq translated this oppositional politics into rule predicated on chadar and chardiwari (the veil and the four walls), taking a metaphor for the practice of women's seclusion and turning it into a metaphor for a political horizon 
that focused on family and home. This was a politics of domestication intended to depoliticize: to bring into being a different type of political subject rather than the national subject or the citizen. I have discussed the techniques and practices associated with this type of cultural formation that entailed a process of Islamization or reIslamization. Domestication and depoliticization proceeded through consumerism, pietism, and a focus on work and individual responsibility. Vigilantism was an effective technique not only to attack elites and enforce piety, but to render public space generally unsafe and encourage retreat into the home or private life. Parliamentary politics and juridical principles were eroded through militarism and the promotion of war; the promotion of gun ownership; the introduction of shariat courts to enforce Islamic punishments; and the introduction of laws that encouraged a privatized notion of justice as retribution and compensation. "Islamic studies" were foregrounded in education, and forms of collective life and subjectivity articulated through the arts were deemed immoral. Though the government made some efforts to mandate or restrict women's movements or dress in spheres under its direct control, other means of situating the moral woman in the home included eliminating rape as a crime, outlawing abortion, encouraging the public harassment of women, and portraying working women as immoral. Middle class women were at the forefront of protests against Zia-ul-Haq's Islamization, even while they experienced the effects of the government's attempts to reconstitute moral subjectivity: effects they described in interviews as disaggregation, depoliticization, a "shackling" of thought, a loss of a political language, and an embodied sense of shame and dishonour. 
The laws that were introduced by Zia-ul-Haq as part of his efforts to create an Islamic system of government are still in effect. A 1985 constitutional amendment validated all laws introduced during Zia-ul-Haq's pre-1985 martial law administration so that they could not be challenged in court in the future. Overturning this amendment required the support of two-thirds of the members of the National Assembly and the Senate, something that two subsequent governments led by Benazir Bhutto were never able to accomplish. Zia-ul-Haq's constitutional changes, allowing easy dismissal of parliaments by the President, together with the military leadership's insistence on maintaining its political and economic power, resulted in a pattern throughout the 1990s of weak and short-lived civilian administrations. ${ }^{1}$ The Pakistan People's Party led by Benazir Bhutto won the most seats in the national assembly, though not a majority, in the November 1988 party-based elections. The PPP government was dismissed by the President in 1990. The next elections brought a coalition of the Pakistan Muslim League, the Jamaat-i-Islami, and smaller religious parties to power led by Nawaz Sharif, a close political ally of Zia-ul-Haq. Nawaz Sharif's government was dismissed in 1993 followed by another PPP administration that was dismissed in 1996. After the next set of elections, Nawaz Sharif became Prime Minister once again and was ousted by a military coup in 1999, marking the beginning of a ten year period of military rule under General Pervez Musharraf.

The Nawaz Sharif governments were ideologically committed to Zia-ul-Haq's program of Islamization and continued to pursue legal changes that were initiated under Zia-ul-Haq. The Qisas and Diyat laws, which had been kept alive from the Zia-ul-Haq era

\footnotetext{
${ }^{1}$ The power of the President to dismiss elected governments was finally abolished in April 2010.
} 
through continuously renewed presidential ordinances, finally became law in 1997 . A Shariat Act, passed in May of 1991, did not expand the jurisdiction of the Federal Shariat Court or impact standards of interpretation used by higher courts (Kennedy, 1992:77980). With a large parliamentary majority during his second government, Nawaz Sharif attempted to enact stronger shariat legislation in the form of a constitutional amendment, but his government was toppled before it could achieve this objective. General Musharraf as President had less enthusiasm than Zia-ul-Haq for Islamic law, though the military continues to use Islamist militias for its own purposes. In 2006, the Hudood laws were amended to permit rape cases to be prosecuted in civil courts rather than shariat courts, a minor amendment that continues to be legally challenged by the ulama and criticized by those demanding the Hudood laws be repealed altogether.

As discussed here, Zia-ul-Haq used various means to undermine a deliberative political sphere, and to promote the view that beyond a concern with local issues, there was no meaning or purpose to political activity. An emptying out of the content of parliamentary politics was indeed evident subsequent to Zia-ul-Haq's rule. While they differed on matters of Islamic law, the PPP and the Muslim League-led coalition did not differ considerably in other respects. Both governments pursued economic liberalization. Policies such as nationalization, land reform, or anything involving socialism, were gone from the PPP platform, and the ability to enact any social legislation was constrained by the scarcity of government revenue in comparison to crippling defense expenditures. The first PPP government led by Benazir Bhutto produced a dearth of legislation and appeared to focus instead on the task of dispersing patronage and purchasing loyalty (Jalal, 1995:110-111). Post-Zia-ul-Haq governments prioritized their ability to enrich 
supporters, while policy platforms and popular mobilization were secondary issues. During the 1990s elected members of the PPP and the Pakistan Muslim League switched allegiances frequently for financial reward.

The Saudi-funded madrasahs and the military training camps set up to wage "jihad" provided one of the most lasting legacies of the 1980s. The growth in armed sectarian groups has continued since the 1980s and Pakistan's military intelligence has used such groups for its purposes in Kashmir and Afghanistan. As discussed in Chapter Five, new forms of Islamic activism emerged at this time that were not focused on achieving state power, on jurisprudence, or on building the institutional structure of an Islamic state. The Taliban is one such organization that emerged from the madrasahs and military training camps of northwest Pakistan during the 1990s. They emphasize capturing territory through military conquest, removing all existing structures of government, attacking existing authority figures, and violently enforcing select codes of behaviour. Organizations such as the Taliban reflect processes evident during Zia-ulHaq's rule, including individualization; denationalization; what Roy (2004) refers to as a "deterritorialized" politics; the militarization of Islam and the emphasis on war; the elevation of the young, usually armed, male vigilante as an agent of change; and the decline of the social and the political.

In April of 2009, all political parties in Pakistan's National Assembly, with the exception of the MQM, voted in favour of a "peace" agreement that would relinquish federal and provincial control of the Swat valley in the province of NWFP to the Taliban. The Taliban had been waging an assassination campaign against provincial politicians and the Assembly vote was undoubtedly shaped by fear of further killings. But that the 
parliament would sanction the extra-constitutional rule of the Taliban, with the attendant closing of schools, shutting down of the judicial system, suspension of health and social services, and violence against the population in a province that had only just elected a government led by the secular Awami National Party, clearly demonstrated the erosion of national sovereignty. It also revealed the distance between parliament and the military and the inability of the former to command the latter, although subsequent domestic and international pressure forced a military campaign to oust the Taliban from Swat.

Parliamentary sovereignty is further diminished through Pakistan's involvement in the American "war on terror." This is not simply the case because Pakistan's military, to the extent that it answers to any authority external to itself, appears to be more responsive to international powers than the country's own civilian administration. It is also because, as the history I have traced here shows, the military is a key institution in emerging political forms where it is conjoined with religious political movements to create a politics that some have likened to fascism, though as yet there is not an adequate language to describe this new, complex and varied political landscape. In this thesis I have given attention to the history of the military in Pakistan alongside processes of liberal state formation and the emergence of Islamism because, to borrow from Foucault, it is part of the "history of the present" (1979:31). As they contend with the terrible legacy of the 1980s, Pakistan's inhabitants, and indeed those that are impacted elsewhere as well, are being offered further war and militarism to protect them from jihadist Islam. In Pakistan the military is widely regarded as an institution that is not tainted by the political and is therefore somehow truly "national." Still others question whether this discourse of political corruption versus military strength and virtue can offer anything of 
value - anything that it has not been able to deliver for decades now. Any answer to this question should not only bear in mind the military's part in bringing the Taliban into being, but also that the military is an institution with almost no women in it, an institution that regularly oversteps constitutional norms, an institution that drains the resources of a poor country, and an institution with a rationality that is antagonistic to democratic governance. Zia-ul-Haq placed military personnel in all government and public institutions to facilitate a process of destroying what he considered to be the illegitimate sphere of the political.

Despite the sobering political conjuncture of the present, this thesis has focused on practices and contingent and temporal components of rule, as well as on political projects that have multiple, often contradictory, effects. Islamization is not coterminous with "Islam." Islamization itself has been associated with liberal state formation as well as Islamism and militarism. Although Islamism has linked up with military rule, some Islamists critique military rule, as well as jihadism. Liberalism has had a history of egalitarianism, as well as racism, classism and imperialism. Despite its history of authoritarianism and militarism, Pakistan has women's groups; trade unions; multiple political parties; peasant groups; tribal leaders opposed to jihadism; popular Islamic traditions that offer alternatives to a fixation on moral codes; a judiciary that appears increasingly willing to challenge the military; and a strong and critical media. In this thesis, I have not intended to tell a story of over-arching domination, but to render many concepts and categories including Islam, liberalism, and modernity, less stable, more contingent, and more open to the possibility of a range of political projects. 


\section{Glossary}

Ahmadi - A follower of the Muslim religious movement founded by Mirza Ghulam Ahmad (1835-1908), who claimed to be a prophet.

Amir-Chief or leader.

Aligarh - A city in Uttar Pradesh, India. The name of the city is associated with "Islamic Modernism," the intellectual tradition promoted by Sayyid Ahmad Khan and the Mohammadan Anglo-Oriental College (later Aligarh Muslim University) that he established in the city in 1875 .

Ashraf-Nobility, aristocracy, or "respectable" people.

Awami - "People's." Of or belonging to the people (awam).

Bihishti Zewar - "Heavenly Ornaments." The title of Maulana Ashraf Ali Thanawi's famous guidebook for women first published in 1905.

Biraderi - "Brotherhood." Patrilineal kinship structure.

Burqa - A garment worn over the head that covers the entire body.

Chadar - A large cloth or shawl worn over the head and around the shoulders.

Chadar aor Chardiwari: "The veil and the four walls." A reference to purdah.

Deobandi - A follower of the teachings of the Dar al-Ulum Madrasah founded in 1867 in the city of Deoband in Uttar Pradesh, India, or a reformist Islamic orientation associated with the religious movement that originated in the Deoband Madrasah.

Diyat - "Blood money" or money to be paid by the perpetrator of a crime to the victim of the crime or the victim's heir.

Dupatta - A long scarf usually worn over the shoulders.

Fatwa-A religious decree or ruling given by a member of the ulama. 
Fiqh - Islamic law or jurisprudence.

Hadith (singular hadis) - Sayings and traditions attributed to the Prophet Mohammad.

Hudood - Punishments specified in Islamic scripture.

Imam - Prayer leader. Leader or head of a mosque. In Shia Islam it also refers to infallible spiritual guides descended from Ali, the Prophet Mohammad's son-inlaw.

Islami Jamiat-i Tulaba (IJT) - Islamic Society of Students. (The student wing of the Jamaat-i-Islami.)

Islamiyat - Islamic Studies.

Izzat - Honour.

Jirga - Tribal council.

Jamaat-i-Islami - Party of Islam.

Jamaat-Ulama-i-Islam - Party of the Ulama of Islam. Associated with the Deobandi movement.

Jamiat-ul-Ulama-i-Pakistan - Party of the Ulama of Pakistan. Associated with the Barelwi movement and orientation in South Asian Islam, which is rooted in a rural, popular, Sufi-influenced Islamic practice.

Jihad - Struggle. It can mean to struggle or strive on a religious path, but recently has often been equated with "holy war."

Khilafat-Caliphate.

Madrasah - Islamic school.

Majlis-i-shoora - Advisory Council. 
Mardana - Physical and cultural space inhabited by men under the gendered spatial arrangements of purdah.

Maulvi - Muslim religious leader or religious instructor.

Mohalla - Neighbourhood.

Muhajir - Refugee or migrant. Muhajirs were migrants who followed the Prophet Mohammad from Mecca to Medina. In Pakistan the term is specifically used for Muslims who migrated to Pakistan from India around the time of the 1947 partition of India, and for their descendants.

Muhajir Qaumi Movement (MQM) - Muhajir National Movement.

Mujahideen - Those who engage in jihad. The term was used for resistance fighters who opposed the communist government and Soviet army in Afghanistan during the 1980 s.

Mullah - Islamic authority figure or leader, particularly one without extensive formal religious training or higher theological education.

Mushaikh - Religious leaders, particularly Sufi religious leaders.

Nizam-e-Islam - System or rule of Islam.

Nizam-e-Mustapha-System or rule of the Prophet.

Nazim-e-Salaat - Prayer monitors or enforcers.

Pir - Sufi spiritual guide or saint.

Panchayat - Village council or assembly.

Pandit - Hindu religious scholar.

Purdah - "Curtain." The practice of women's veiling and seclusion.

Qisas - Retribution. 
Qazi-Islamic judge.

Satyagraha - Truth force. Mohandas K. Gandhi's philosophy and practice of non-violent political resistance.

Shariat - Islamic law and ethics.

Sharif-Noble or respectable. Singular form of Ashraf.

Sipah-e-Sahaba-Soldiers or Army of the Companions of the Prophet Mohammad. A violent Sunni sectarian organization that emerged in Pakistan during the 1980s. Sunnah - The teachings of the Prophet Mohammad.

Tablighi Jamaat - An Islamic proselytizing movement.

Taliban - "Students." A puritanical political movement that emerged among militarilytrained students of madrasahs in north-west Pakistan during the 1990s.

Tehrik-i-Istaqlal - Party of Stability. A nationalist party founded by retired military officer, Mohammad Asghar Khan, during the 1970s.

Ulama - Formally-trained scholars in Islamic texts and jurisprudence.

Zakat - Alms required to be paid to the poor as a religious duty in Islam.

Zina-Adultery and fornication.

Zenana - Physical and cultural space inhabited by women practicing purdah. 


\section{Sources}

\section{Newspaper Articles}

Dawn, "Text of PNA manifesto." February 10, 1977.

Dawn, "Bhutto promises many more reforms." March 3, 1977.

Dawn, "PPP not competent to enforce Islamic system." March 3, 1977.

Dawn, "Fight between socialism and Islam says Ghafoor." March 5, 1977.

Dawn, "Begum Liaquat seeks dialogue with Zia." May 12, 1982.

Dawn, "Begum Liaquat shocked over humiliation of women." May 5, 1984.

Dawn, "WAF's call to combat violence on campuses." January 25, 1987.

Dawn Review, “PPP Manifesto: text of 3rd Chapter." January 26, 1977.

Dawn Review, "People want change says Noorani." February 1, 1977.

Dawn Review, "All except basic industries to be denationalised - Mufti Mahmud." February 13, 1977.

Muslim, "Games Without Women." December 5, 1982.

\section{Political Speeches}

Zia-ul-Haq, General Mohammad. Address to the Nation. July 5, 1977. Islamabad: Government of Pakistan.

Zia-ul-Haq, General Mohammad. Address to the Nation. July 27, 1977. Islamabad. Government of Pakistan.

Zia-ul-Haq, General Mohammad. "Interview to an Iranian Journalist." March 27, 1978, In Interviews to Foreign Media, Vol.I, March-December, 1978. (pp. 18-27). Islamabad: Government of Pakistan.

Zia-ul-Haq, General Mohammad. Address to the Nation. June 25, 1978. Islamabad: Government of Pakistan.

Zia-ul-Haq, General Mohammad. Introduction of Islamic Laws: Address to the Nation. February 10, 1979. Islamabad: Government of Pakistan. 
Zia-ul-Haq, General Mohammad. Every Challenge of anti-Islam Forces will be Defeated; All Realms of National Life to be Reformed; Terrorists to be given Exemplary

Punishment: Fourth Session of Federal Council, Inaugural Address. October 9, 1982.

Islamabad: Government of Pakistan.

Zia-ul-Haq, General Mohammad. Fifth Session of Federal Council: Address. February 5, 1983. Islamabad: Government of Pakistan.

Zia-ul-Haq, General Mohammad. Islam Stands for Unity and Brotherhood: Eighth

Session of Federal Council, Inaugural Address. October 22, 1983. Islamabad:

Government of Pakistan.

Zia-ul-Haq, General Mohammad. Referendum, People's Historic Decision in Favour of Nizam-i-Islam: Address to the Nation. December 21, 1984. Islamabad: Government of Pakistan.

Zia-ul-Haq, General Mohammad. Constitutional Amendments Announced: Address to the Nation. March 2, 1985. Islamabad: Government of Pakistan.

\section{Secondary and Other Works Cited}

Abu-Lughod, Lila (1998a). "Feminist Longings and Postcolonial Conditions." In Lila Abu-Lughod (Ed.), Remaking Women: Feminism and Modernity in the Middle East. (pp. 3-31). Princeton: Princeton University Press.

Abu-Lughod, Lila (1998b). "The Marriage of Feminism and Islamism in Egypt: Selective Repudiation as a Dynamic of Postcolonial Cultural Politics." In Lila Abu-Lughod (Ed.), Remaking Women: Feminism and Modernity in the Middle East. (pp. 243269). Princeton: Princeton University Press.

Aftab, Tahera (2005). "Negotiating with Patriarchy: South Asian Muslim Women and the Appeal to Sir Syed Ahmed Khan." Women's History Review, 14(1), 75-97.

Ahmad, Aijaz (1983). "Democracy and Dictatorship." In Hassan Gardezi and Jamil Rashid (Eds.) Pakistan: The Roots of Dictatorship. (pp. 94-147). London: Zed Press.

Ahmad, Aijaz (2000). Lineages of the Present: Ideology and Politics in Contemporary South Asia. London: Verso.

Ahmad, Aziz (1967). Islamic Modernism in India and Pakistan, 1857-1964. London: Oxford University Press. 
Ahmad, Mumtaz (1991). "Islamic Fundamentalism in South Asia: The Jamaat-i-Islami and the Tablighi Jamaat." In Martin E. Marty and R. Scott Appleby (Eds.), Fundamentalisms Observed. (pp. 457-530). Chicago: University of Chicago Press.

Ahmed, Leila (1992). Women and Gender in Islam. New Haven: Yale University Press.

Alavi, Hamza (1976). "The Rural Elite and Agricultural Development in Pakistan." In Robert D. Stevens, Hamza Alavi, and Peter J. Bertoccio (Eds.), Rural Development in Bangladesh and Pakistan. (pp. 317-353). Honolulu: The University Press of Hawaii.

Alavi, Hamza (1983). "Class and State." In Hassan Gardezi and Jamil Rashid (Eds.), Pakistan: The Roots of Dictatorship. (pp. 40-93). London: Zed Press.

Alavi, Hamza (1986). "Ethnicity, Muslim Society and the Pakistan Ideology." InAnita M. Weiss (Ed.), Islamic Reassertion in Pakistan: The Application of Islamic Laws in a Modern State. (pp.21-48). Syracuse: Syracuse University Press.

Alavi, Hamza (2001). "The Two Biraderis: Kinship in Rural West Punjab." In T.N. Madan (Ed.), Culture, Society and Power. (pp. 25-75). Delhi: Manohar.

Ali, Azra Asghar (2000). The Emergence of Feminism among Indian Muslim Women, 1920-1947. Oxford: Oxford University Press.

Ali, Babar (1988). "Elitist View of Women's Struggle in Pakistan." Economic and Political Weekly, 23(20), 1034-1036.

All Pakistan Women's Association Punjab (1994). "Education, Health, Employment, Women's Rights." (unpublished booklet), Lahore: APWA Punjab.

Alter, Joseph S. (1996). "Gandhi's Body, Gandhi's Truth: Nonviolence and the Biomoral Imperative of Public Health." Journal of Asian Studies, 55(2), 301-322.

Amin, Sonia Nishat (1996). The World of Muslim Women in Colonial Bengal, 18761939. Leiden: E.J.Brill.

Amnesty International (1999). Pakistan: Honour Killings of Girls and Women. Retrieved on November 15, 2010 from http://www.amnesty.org/en/library/asset/ASA33/018/1999/en/9fe83c27-e0f111dd-be39-2d4003be4450/asa330181999en.pdf.

Anagol, Padma (2005). The Emergence of Feminism in India, 1850-1920. Aldershot: Ashgate. 
Anderson, Benedict (1991). Imagined Communities: Reflections on the Origin and Spread of Nationalism. Revised Edition. London: Verso.

Anderson, Michael R. (1990). "Islamic Law and the Colonial Encounter in British India." In Chibli Mallat and Jane Connors (Eds.), Islamic Family Law. (pp. 205-223). London: Graham and Trotman.

Ansari, Sarah (1992). Sufi Saints and State Power: The Pirs of Sind, 1843-1947. Cambridge: Cambridge University Press.

Ansari, Sarah (2009). "Polygamy, Purdah and Political Representation: Engendering Citizenship in 1950s Pakistan." Modern Asian Studies, 43(6), 1421-1461.

Arnold, David (2000). Science, Technology and Medicine in Colonial India. Cambridge: Cambridge University Press.

Asad, Talal (1993). Genealogies of Religion: Discipline and Reasons of Power in Christianity and Islam. Baltimore: The Johns Hopkins University Press.

Asad, Talal (2003). Formations of the Secular: Christianity, Islam, Modernity. Stanford: Stanford University Press.

Asia Watch and the Women's Rights Project (1992). Double Jeopardy: Police Abuse of Women in Pakistan. New York: Human Rights Watch.

Ayub Khan, Mohammad (1967). Friends Not Masters: A Political Autobiography. Lahore: Oxford University Press.

Baitenmann, Helga (1990). "NGOs and the Afghan War: The Politicisation of Humanitarian Aid." Third World Quarterly, 12(1), 62-85.

Ballhatchet, Kenneth (1980). Race, Sex, and Class under the Raj: Imperial Attitudes and Policies and their Critics, 1793-1905. London: Weidenfeld and Nicolson.

Banerjee, Nirmala (1989). "Working Women in Colonial Bengal: Modernization and Marginalization." In Kumkum Sangari and Sudesh Vaid (Eds.), Recasting Women: Essays in Colonial History. (pp. 269-301). New Delhi: Kali for Women.

Banerjee, Sumanta (1989a). The Parlour and the Streets: Elite and Popular Culture in Nineteenth Century Calcutta. Calcutta: Seagull Books.

Banerjee, Sumanta (1989b). "Marginalization of Women's Popular Culture in Nineteenth Century Bengal." In Kumkum Sangari and Sudesh Vaid (Eds.), Recasting Women: Essays in Colonial History. (pp. 127-179). New Delhi: Kali for Women. 
Bannerji, Himani (2000). "Projects of Hegemony: Towards a Critique of Subaltern Studies' 'Resolution of the Women's Question'." Economic and Political Weekly, 35(11), 902-920.

Baxter, Craig (1991). "Restructuring the Pakistan Political System" In Shahid Javed Burki and Craig Baxter (Eds.), Pakistan Under the Military: Eleven Years of Zia ul-Haq. (pp. 27-48). Boulder: Westview Press.

Bayly, C.A. (1983). Rulers, Townsmen, and Bazaars: North Indian Society in the Age of British Expansion, 1770-1870. New York: Cambridge University Press.

Bose, Sugata (1986). Agrarian Bengal: Economy, Social Structure and Politics, 19191947. Cambridge: Cambridge University Press.

Braibanti, Ralph (1966). Research on the Bureaucracy of Pakistan. Durham, N.C.: Duke University Press.

Brown, Nathan J. (1997). "Shari'a and State in the Modern Middle East." International Journal of Middle East Studies, 29(3), 359-376.

Brown, Wendy (1992). "Finding the Man in the State." Feminist Studies, 18(1), 7-34.

Brown, Wendy (2004). “"The Most We Can Hope For...': Human Rights and the Politics of Fatalism." The South Atlantic Quarterly, 103(2/3), 451-463.

Brown, Wendy (2006a). "American Nightmare: Neoliberalism, Neoconservatism, and De-Democratization." Political Theory, 34(6), 690-714.

Brown, Wendy (2006b). Regulating Aversion: Tolerance in the Age of Identity and Empire. Princeton: Princeton University Press.

Burki, Shahid Javed (1980). Pakistan Under Bhutto, 1971-1977. London: Macmillan.

Burki, Shahid Javed (1991). "Pakistan's Economy Under Zia." In Shahid Javed Burki and Craig Baxter (Eds.), Pakistan Under the Military: Eleven Years of Zia ulHaq. (pp. 87-114). Boulder: Westview Press.

Burton, Antoinette (1994). Burdens of History: British Feminists, Indian Women, and Imperial Culture, 1865-1915. Chapel Hill: University of North Carolina Press.

Butalia, Urvashi (2000a). The Other Side of Silence: Voices from the Partition of India. Durham, N.C.: Duke University Press.

Butalia, Urvashi (2000b). "Community, State, and Gender: Some Reflections on the Partition of India." In Mushirul Hasan (Ed.), Inventing Boundaries: Gender, 
Politics and the Partition of India. (pp. 178-207). New Delhi: Oxford University Press.

Callard, Keith (1968). Pakistan: A Political Study. Karachi: Oxford University Press.

Canadian Broadcasting Corporation. "Back to School in Afghanistan." Retrieved on November 15, 2010 from http://www.cbc.ca/news/background/afghanistan/ schools.html.

Carroll, Lucy (1982). "Nizam-I-Islam: Processes and Conflicts in Pakistan's Programme of Islamisation, with Special Reference to the Position of Women." Journal of Commonwealth and Comparative Politics, 20, 57-95.

Carroll, Lucy (2008). "Law, Custom and Statutory Social Reform: The Hindu Widows' Remarriage Act of 1856." In Sumit Sarkar and Tanika Sarkar (Eds.), Women and Social Reform in Modern India: A Reader. (pp. 78-99). Bloomington: Indiana University Press.

Chakrabarty, Dipesh (1993). "The Difference—Deferral of (A) Colonial Modernity: Public Debates on Domesticity in British Bengal." History Workshop, 36(Autumn), 1-34.

Chakravarti, Uma (1989). "Whatever Happened to the Vedic Dasi? Orientalism, Nationalism and a Script for the Past." In KumKum Sangari and Sudesh Vaid (Eds.), Recasting Women: Essays in Colonial History. (pp. 27-87). New Delhi: Kali for Women.

Chatterjee, Partha (1989). "The Nationalist Resolution of the Women's Question" In Kumkum Sangari and Sudesh Vaid (Eds.), Recasting Women: Essays in Colonial History. (pp. 233-253). New Delhi: Kali for Women.

Chatterjee, Partha (1993). The Nation and Its Fragments: Colonial and Postcolonial Histories. Delhi: Oxford University Press.

Chatterjee, Partha (1997). "The Nation and Its Women" In Ranajit Guha (Ed.), $A$ Subaltern Studies Reader, 1986-1995. (pp. 240-262). Minneapolis: University of Minnesota Press.

Chipp-Kraushaar, Sylvia (1981). "The All Pakistan Women's Association and the 1961 Muslim Family Laws Ordinance.” In Gail Minault (Ed.), The Extended Family: Women and Political Participation in India and Pakistan. (pp. 263-285). Delhi: Chanakya Publications.

Choueiri, Youssef M. (1997). Islamic Fundamentalism. London: Continuum. 
Clark, Grace (1986). "Pakistan's Zakat and 'Ushr as a Welfare System." In Anita M. Weiss (Ed.), Islamic Reassertion in Pakistan. (pp. 79-95). Syracuse: Syracuse University Press.

Cohen, Stephen P. (1984). The Pakistan Army. Berkeley: University of California Press.

Cohen, Stephen P. (2004). The Idea of Pakistan. Washington, D.C.: Brookings Institution Press.

Cohn, Bernard S. (1983). "Representing Authority in Victorian India." In Eric J.

Hobsbawm and Terence Ranger (Eds.), The Invention of Tradition. (pp. 165-209). Cambridge: Cambridge University Press.

Cohn, Bernard S. (1996). Colonialism and its Forms of Knowledge. Princeton: Princeton University Press.

Connell, R.W. (1990). "The State, Gender and Sexual Politics." Theory and Society, 19, 507-544.

Copland, Ian (1991). "The Princely States, the Muslim League, and the Partition of India in 1947." International History Review, 13(1), 38-69.

Corrigan, Philip and Sayer, Derek (1985). The Great Arch: English State Formation as Cultural Revolution. Oxford: Basil Blackwell.

Daechsel, Markus (2006). The Politics of Self-Expression: The Urdu Middle-Class Milieu in Mid-Twentieth Century India and Pakistan. London: Routledge.

Das, Veena (1995). Critical Events: An Anthropological Perspective on Contemporary India. Delhi: Oxford University Press.

Datta, V.N. (1988). Sati: A Historical, Social and Philosophical Enquiry into the Hindu Rite of Widow Burning. Delhi: Manohar.

Davidoff, Leonore and Hall, Catherine (1987). Family Fortunes: Men and Women of the English Middle Class, 1780-1850. London: Hutchison.

Dean, Mitchell (1991). The Constitution of Poverty: Toward a Genealogy of Liberal Governance. London: Routledge.

Dean, Mitchell (1999). Governmentality: Power and Rule in Modern Society. London: Sage.

Dean, Mitchell (2003). “Cultural Governance and Individualisation.” In Henrik P. Bang (Ed.), Governance as Social and Political Communication. (pp. 117-139). Manchester: Manchester University Press. 
Devji, Faisal Fatehali (2005). Landscapes of the Jihad: Militancy, Morality, Modernity. Ithaca: Cornell University Press.

Devji, Faisal Fatehali (2008). "Gender and the Politics of Space: The Movement for Women's Reform, 1857-1900." In Sumit Sarkar and Tanika Sarkar (Eds.), Women and Social Reform in Modern India. (pp. 378-388). Bloomington: Indiana University Press.

Didur, Jill (2006). Unsettling Partition: Literature, Gender, Memory. Toronto: University of Toronto Press.

Donzelot, Jacques (1979). The Policing of Families. New York: Pantheon Books.

Donzelot, Jacques (1988). "The Promotion of the Social." Economy and Society, 17(3), 395-427.

Eickelman, Dale F. and James Piscatori (1996). Muslim Politics. Princeton: Princeton University Press.

Enloe, Cynthia (2007). Globalization and Militarism: Feminists Make the Link. Lanham, Maryland: Rowman \& Littlefield.

Esposito, John (1998). Islam and Politics. 4th Edition. Syracuse: Syracuse University Press.

Ewing, Katherine Pratt (1997). Arguing Sainthood: Modernity, Psychoanalysis and Islam. Durham, N.C.: Duke University Press.

Forbes, Geraldine (1979). "Votes for Women: The Demand for Women's Franchise in India 1917-1937." In Vina Mazumdar (Ed.), Symbols of Power: Studies on the Political Status of Women in India. (pp. 3-23). Bombay: Allied Publishers.

Forbes, Geraldine (1996). Women in Modern India. Cambridge: Cambridge University Press.

Forbes, Geraldine (2005). Women in Colonial India: Essays on Politics, Medicine, and Historiography. New Delhi: Chronicle Books.

Forbes, Geraldine (2008). "Education for Women." In Sumit Sarkar and Tanika Sarkar (Eds.), Women and Social Reform in Modern India: A Reader. (pp. 58-77). Bloomington: Indiana University Press.

Foucault, Michel (1979). Discipline and Punish: The Birth of the Prison. trans. Alan Sheridan. New York: Vintage Books. 
Foucault, Michel (1984). "Nietzsche, Genealogy, History." In Paul Rabinow (Ed.), The Foucault Reader. (pp. 76-100). New York: Pantheon Books.

Foucault, Michel (1991). "Questions of Method.” In Graham Burchell, Colin Gordon, and Peter Miller (Eds.), The Foucault Effect: Studies in Governmentality. (pp. 7386). Chicago: University of Chicago Press.

Freitag, Sandria B. (1989). Collective Action and Community: Public Arenas and the Emergence of Communalism in North India. Berkeley: University of California Press.

Fullerton, Romey (1983). "Problems Beneath the Veil." Far Eastern Economic Review, June 30,35 .

Gilmartin, David (1981). "Kinship, Women, and Politics in Twentieth Century Punjab." In Gail Minault (Ed.), The Extended Family: Women and Political Participation in India and Pakistan. (pp. 151-173). Columbia, Missouri: South Asia Books.

Gilmartin, David (1988). Empire and Islam: Punjab in the Making of Pakistan. Berkeley: University of California Press.

Gilmartin, David (1998). "Partition, Pakistan, and South Asian History: In Search of a Narrative." Journal of Asian Studies, 57(4), 1068-1095.

Government of Pakistan (1960). Report of the Commission on National Education. Karachi: Ministry of Education.

Guha, Sumit (2003). "The Politics of Identity and Enumeration in India c. 1600-1990." Comparative Studies in Society and History, 45(1), 148-167.

Gustafson, W. Eric (1973). "Economic Reforms under the Bhutto Regime." Journal of Asian and African Studies, 8(3-4), 241-258.

Gustafson, W. Eric and Richter, William L. (1981). "Pakistan in 1980: Weathering the Storm." Asian Survey, 21(2), 162-171.

Habib, Miriam (1984). "Pakistan: Women—A Fractured Profile.” In Robin Morgan (Ed.), Sisterhood is Global: The International Women's Movement Anthology. (pp. 533-538). Middlesex, England: Penguin

Haq, Mahbub ul (1963). The Strategy of Economic Planning: A Case Study of Pakistan. Karachi: Oxford University Press.

Haqqani, Husain (2005). Pakistan: Between Mosque and Military. Washington, D.C.: Carnegie Endowment for International Peace. 
Hardy, Peter (1972). The Muslims of British India. Cambridge: Cambridge University Press.

Haroon, Anis (1994). "Women and Urdu Literature: The Dilemma of the sub-Continent." In Nighat Said Khan, Rubina Saigol, and Afiya Shehrbano Zia (Eds.), Locating the Self: Perspectives on Women and Multiple Identities. (pp. 172-178). Lahore: ASR Publications.

Harrison, Selig S. (1981). In Afghanistan's Shadow: Baluch Nationalism and Soviet Temptations. Washington, D.C.: Carnegie Endowment for International Peace.

Harrison, Selig S. (1986). "Ethnicity and the Political Stalemate in Pakistan." In Ali Banuazizi and Myron Weiner (Eds.), The State, Religion, and Ethnic Politics: Afghanistan, Iran, and Pakistan. (pp. 267-298). Syracuse: Syracuse University Press.

Harrison, Selig S. (2009). Pakistan: The State of the Union. Washington, D.C.: Center for International Policy.

Hasan, Mushirul (1981). "Religion and Politics: The Ulama and the Khilafat Movement." Economic and Political Weekly, 16(20), 903-905, 907-912.

Hasan, Mushirul (1993). "Introduction." In Mushirul Hasan (Ed.), India's Partition: Process, Strategy and Mobilization. (pp. 1-43). Oxford: Oxford University Press.

Hasan, Mushirul (1998). “Aligarh's 'Notre Eminent Contemporain': Assessing Syed Ahmad Khan's Reformist Agenda." Economic and Political Weekly, 33(19), 1077-1081.

Hasan, Mushirul (2000). "Prologue: India's Partition Revisited." In Mushirul Hasan (Ed.), Inventing Boundaries: Gender, Politics and the Partition of India. (pp. 125). New Delhi: Oxford University Press.

Hasan, Zoya (Ed.), (2004). Forging Identities: Gender, Communities and the State in India. Bouder: Westview.

Hatem, Mervat F. (1992). "Economic and Political Liberation in Egypt and the Demise of State Feminism." International Journal of Middle East Studies. 24, 231-252.

Hatem, Mervat (1994). "Egyptian Discourses on Gender and Political Liberalization: Do Secularist and Islamist Views Really Differ?" Middle East Journal, 48(4), 661676.

Hirschkind, Charles (1997). "What is Political Islam?" Middle East Report, 205, 12-14. 
Hirschkind, Charles (2001). "Civic Virtue and Religious Reason: An Islamic Counterpublic." Cultural Anthropology, 16(1), 3-34.

Hirschkind, Charles and Mahmood, Saba (2002). "Feminism, the Taliban, and Politics of Counter-Insurgency." Anthropological Quarterly, 75(2), 339-354.

Hossain, Rokeya Sakhawat (1988). "Selections from The Secluded Ones." In Roushan Jahan (Ed.), Sultana's_Dream and Selections from The Secluded Ones. (pp. 2436). New York: The Feminist Press at the City University of New York.

Hourani, Albert (1991). A History of the Arab Peoples. New York: Warner Books.

Human Rights Watch (1999). Crime or Custom? Violence Against Women in Pakistan. New York: Human Rights Watch.

Huntington, Samuel P. (1996). The Clash of Civilizations and the Remaking of World Order. New York: Simon \& Schuster.

Hussain, Neelam (1996). "Television Drama." In Maha Malik and Neelam Hussain (Eds.), Re-inventing Women: Representation of Women in the Media during the Zia Years. (pp. 22-42). Lahore: Simorgh Women's Resource and Publication Centre.

Inayatullah (1964). Administrator and the Citizen. Lahore: National Institute of Public Administration.

Iqbal, Javid (1990). "Crimes Against Women in Pakistan." Journal of South Asian and Middle Eastern Studies, 13(3), 37-48.

Ismail, Salwa (2003). Rethinking Islamist Politics: Culture, the State and Islamism. London: I.B.Tauris.

Ismail, Salwa (2006). Political Life in Cairo's New Quarters: Encountering the Everyday State. Minneapolis: University of Minnesota Press.

Jahan, Rounaq (1972). Pakistan: Failure in National Integration. New York: Columbia University Press.

Jahan, Roushan (1988). "The Secluded Ones: Purdah Observed." In Roushan Jahan (Ed.), Sultana's Dream: A Feminist Utopia and Selections from The Secluded Ones. By Rokeya Sakhawat Hossain, edited and translated by Roushan Jahan. (pp.19-23). New York: The Feminist Press at The City University of New York.

Jahangir, Asma and Jilani, Hina (1990). The Hudood Ordinances: A Divine Sanction? Lahore: Rhotas Books. 
Jalal, Ayesha (1985). The Sole Spokesman: Jinnah, the Muslim League and the Demand for Pakistan. Cambridge: Cambridge University Press.

Jalal, Ayesha (1990). The State of Martial Rule: The Origins of Pakistan's Political Economy of Defense. Cambridge: Cambridge University Press.

Jalal, Ayesha (1991). "The Convenience of Subservience: Women and the State in Pakistan" In Deniz Kandiyoti (Ed.), Women, Islam and the State. (pp. 77-114). Philadelphia: Temple University Press.

Jalal, Ayesha (1995). Democracy and Authoritarianism in South Asia. Cambridge: Cambridge University Press.

Jalal, Ayesha (1996). "Secularists, Subalterns and the Stigma of 'Communalism': Partition Historiography Revisited." Modern Asian Studies, 30(3), 681-689.

Jalal, Ayesha (2008). Partisans of Allah. Cambridge, MA: Harvard University Press.

Jamal, Amina (2006). "Gender, Citizenship, and the Nation-State in Pakistan: Willful Daughters or Free Citizens." Signs, 31(2), 283-304.

Jilani, Hina; Jahangir, Asma; and Zia, Shahla (1988). Muslim Family Laws and Their Implementation in Pakistan. Islamabad: Government of Pakistan, Ministry of Women Development.

John, Mary E. (2000). “Alternate Modernities? Reservations and Women's Movement in $20^{\text {th }}$ Century India." Economic and Political Weekly, 35(43/44), 3822-3829.

Jones, Kenneth W. (1989). Socio-Religious Reform Movements in British India. Cambridge: Cambridge University Press.

Kabeer, Naila (1991). "The Quest for National Identity: Women, Islam and the State of Bangladesh." In Deniz Kandiyoti (Ed.), Women, Islam and the State. (pp. 115143). Philadelphia: Temple University Press.

Kandiyoti, Deniz (1988). "Bargaining with Patriarchy." Gender and Society, 2(3), 274290.

Kandiyoti, Deniz (1991). "Introduction." In Deniz Kandiyoti (Ed.), Women, Islam and the State. (pp. 1-21). Philadelphia: Temple University Press.

Kazi, Shahnaz (1989). "Some Measures of the Status of Women in the Course of Development in South Asia" In V. Kanesalingam (Ed.), Women in Development in South Asia. (pp.19-52). New Delhi: Macmillan. 
Kazi, Shahnaz (1991). "Women's Employment and Related Issues." In Fareeha Zafar (Ed.), Finding Our Way: Readings on Women in Pakistan. (pp. 111-124). Lahore: ASR.

Kennedy, Charles H. (1987). Bureaucracy in Pakistan. Karachi: Oxford University Press.

Kennedy, Charles H. (1990). “Islamization and Legal Reform in Pakistan, 1979-1989." Pacific Affairs, 63(1), 62-77.

Kennedy, Charles H. (1992). "Repugnancy to Islam - Who Decides?" International and Comparative Law Quarterly, 41(4), 769-788.

Khan, Ra'ana Liaquat Ali (n.d.). Challenge and Change: Speeches by Begum Ra'ana Liaquat Ali Khan. F.D. Douglas (Ed.), Karachi: All Pakistan Women's Association.

Khan, Shaharyar M. (2000). The Begums of Bhopal: A Dynasty of Women Rulers in Raj India. New York: St. Martin Press.

Khan, Shahnaz (2006). Zina, Transnational Feminism, and the Moral Regulation of Pakistani Women. Vancouver: UBC Press.

Khan, Yasmin (2007).The Great Partition: The Making of India and Pakistan. New Haven: Yale University Press.

Khattak, Saba Gul (2003). "In/Security: Afghan Refugees and Politics in Pakistan." Critical Asian Studies, 35(2), 195-208.

Khattak, Saba Gul (2004). "Adversarial Discourses, Analogous Objectives: Afghan Women's Control." Cultural Dynamics, 16(23), 213-236.

Korson, J. Henry and Maskiell, Michelle (1985). "Islamization and Social Policy in Pakistan: The Constitutional Crisis and the Status of Women." Asian Survey, 25(6), 589-612.

Koven, Seth and Michel, Sonya (1993). "Introduction: 'Mother Worlds'." In Seth Koven and Sonya Michel (Eds.), Mothers of a New World: Maternalist Politics and the Origins of Welfare States. (pp. 1-42). New York: Routledge.

Kozlowski, Gregory C. (2008). "Muslim Women and the Control of Property in North India." In Sumit Sarkar and Tanika Sarkar (Eds.), Women and Social Reform in Modern India: A Reader. (pp. 326-341). Bloomington: Indiana University Press.

Kumar, Kapil (1989). "Rural Women in Oudh 1917-47: Baba Ramchandra and the Women's Question." In Kumkum Sangari and Sudesh Vaid (Eds.), Recasting Women: Essays in Colonial History. (pp. 337-369). New Delhi: Kali for Women. 
Kumar, Radha (1993). The History of Doing: An Illustrated Account of Movements for Women's Rights and Feminism in India, 1800-1990. New Delhi: Kali for Women.

Lambert-Hurley, Siobhan (2004). "Fostering Sisterhood: Muslim Women and the AllIndia Ladies' Association." Journal of Women's History, 16(2), 40-65.

Lelyveld, David (1996). Aligarh's First Generation: Muslim Solidarity in British India. New Delhi: Oxford University Press.

Levine, Philippa (1994). "Venereal Disease, Prostitution, and the Politics of Empire: the Case of British India." Journal of the History of Sexuality, 4(4), 579-602.

Lewis, Bernard (1990). "The Roots of Muslim Rage." Atlantic, September, 47-60.

Liddle, Joanna and Joshi, Rama (1986). Daughters of Independence: Gender, Caste and Class in India. London: Zed.

MacKinnon, Catherine A. (1989). Toward a Feminist Theory of the State. Cambridge, MA: Harvard University Press.

Malhotra, Anshu (2002). Gender, Caste, and Religious Identities: Restructuring Class in Colonial Punjab. New Delhi: Oxford University Press.

Malik, Jamal (1996). Colonization of Islam: Dissolution of Traditional Institutions in Pakistan. Delhi: Manohar.

Mani, Lata (1989). "Contentious Traditions: The Debate on Sati in Colonial India." In Kumkum Sangari and Sudesh Vaid (Eds.), Recasting Women: Essays in Colonial History. (pp. 88-126). New Delhi: Kali for Women.

Mani, Lata (1998). Contentious Traditions: The Debate on Sati in Colonial India. Berkeley: University of California Press.

Masud, Muhammad Khalid (2009). "Islamic Modernism" In Muhammad Khalid Masud, Armando Salvatore, and Martin van Bruinessen (Eds.), Islam and Modernity: Key Issues and Debates. (pp. 237-260). Edinburgh: Edinburgh University Press.

Maududi, Abul A'La (1972). Purdah and the Status of Women in Islam. Lahore: Islamic Publications Limited.

Mayaram, Shail (1997). Resisting Regimes: Myth, Memory, and the Shaping of a Muslim Identity. Delhi: Oxford University Press.

Mayo, Katherine (1927). Mother India. London: Cape. 
McDonough, Sheila (1984). Muslim Ethics and Modernity: A Comparative Study of the Ethical Thought of Sayyid Ahmad Khan and Mawlana Mawdudi. Waterloo, ON: Wilfrid Laurier University Press.

Mehdi, Rubya (1990). "The Offence of Rape in the Islamic Law of Pakistan." International Journal of the Sociology of Law, 18, 19-29.

Mehdi, Rubya (1994). The Islamization of the Law in Pakistan. Richmond, Surrey: Curzon Press.

Mehta, Uday Singh (1999). Liberalism and Empire: A Study in Nineteenth-Century British Liberal Thought. Chicago: University of Chicago Press.

Menon, Ritu and Bhasin, Kamla (1996). "Abducted Women, the State and Questions of Honour: Three Perspectives on the Recovery Operation in Post-Partition India." In Kumari Jayawardena and Malathi de Alwis (Eds.), Embodied Violence: Communalising Women's Sexuality in South Asia. (pp. 1-31). London: Zed Books.

Menon, Ritu and Bhasin, Kamla (1998). Borders and Boundaries: Women in India's Partition. New Delhi: Kali for Women.

Menon, Ritu and Bhasin, Kamla (2000). "Recovery, Rupture, Resistance: The Indian State and the Abduction of Women during Partition." In Mushirul Hasan (Ed.), Inventing Boundaries: Gender, Politics and the Partition of India. (pp. 208-235). New Delhi: Oxford University Press.

Messick, Brinkley (1993). The Calligraphic State: Textual Domination and History in a Muslim Society. Berkeley: University of California Press.

Metcalf, Barbara Daly (1982). Islamic Revival in British India: Deoband, 1860-1900. Princeton: Princeton University Press.

Metcalf, Barbara Daly (1984). "Iqbal: Ideology in Search of an Audience." In C.M. Naim, Fazlur Rehman, Saleem M.M. Qureshi, Manvoor ud din Ahmed, Anwar Syed, Sheila McDonough, Barbara Metcalf, and Lawrence Ziring (Eds.), Iqbal, Jinnah and Pakistan: The Vision and the Reality. (pp. 122-132). Lahore: Vanguard Books.

Metcalf, Barbara Daly (1990). Perfecting Women: Maulana Ashraf 'Ali Thanawi's Bihishti Zewar: A Partial Translation with Commentary. Berkeley: University of California Press.

Metcalf, Barbara Daly (1994). "Reading and Writing about Muslim Women in British India." In Zoya Hasan (Ed.), Forging Identities: Gender, Communities and the State in India. (pp. 1-21). Boulder: Westview Press. 
Metcalf, Barbara Daly (2009). Husain Ahmad Madani: The Jihad for Islam and India's Freedom. Oxford: Oneworld.

Metcalf, Thomas R. (1979). Land, Landlords, and the British Raj: Northern India in the Nineteenth Century. Berkeley: University of California Press.

Metcalf, Thomas R. (1995). Ideologies of the Raj. Cambridge: Cambridge University Press.

Miller, Pavla (1998). Transformations of Patriarchy in the West, 1500-1900. Bloomington: Indiana University Press.

Miller, Ruth (2007). "Rights, Reproduction, Sexuality, and Citizenship in the Ottoman Empire and Turkey." Signs, 32(2), 347-373.

Minault, Gail (1981). "Introduction: The Extended Family as Metaphor and the Expansion of Women's Realm." In Gail Minault (Ed.), The Extended Family: Women and Political Participation in India and Pakistan. (pp. 3-18). Delhi: Chanakya Publications.

Minault, Gail (1982). The Khilafat Movement: Religious Symbolism and Political Mobilization in India. New York: Columbia University Press.

Minault, Gail (1986). Voices of Silence: English translation of Khwaja Altaf Hussain Hali's Majalis un-nissa and Chup ki dad. New Delhi: Chanakya Publications.

Minault, Gail (1994). "Other Voices, Other Rooms: The View from the Zenana." In Nita Kumar (Ed.), Women as Subjects: South Asian Histories. (pp. 108-124). Charlottesville: University Press of Virginia.

Minault, Gail (1998). Secluded Scholars: Women's Education and Muslim Social Reform in Colonial India. New Delhi: Oxford University Press.

Minault, Gail (2008). "Sayyid Mumtaz 'Ali and Tahzib un-Niswan: Women's Rights in Islam and Women's Journalism in Urdu." In Sumit Sarkar and Tanika Sarkar (Eds.), Women and Social Reform in Modern India: A Reader. (pp. 359-377). Bloomington: Indiana University Press.

Mitchell, Timothy (1991). Colonising Egypt. Berkeley: University of California Press.

Moaddel, Mansoor (2005). Islamic Modernism, Nationalism, and Fundamentalism: Episode and Discourse. Chicago: University of Chicago Press.

Moghadam, Valentine M. (1993). Modernizing Women: Gender and Social Change in the Middle East. Boulder: Lynne Rienner. 
Morgan, Robin (1984). "Pakistan." In Robin Morgan (Ed.), Sisterhood is Global: The International Women's Movement Anthology. (pp. 528-533). Middlesex, England: Penguin.

Mumtaz, Khawar (1991). "Khawateen Mahaz-e-Amal and Sindhiani Tehrik: Two Responses to Political Development in Pakistan." South Asia Bulletin, XI(1\&2), 101-109.

Mumtaz, Khawar and Shaheed, Farida (1987). Women of Pakistan: One Step Forward, Two Steps Back. London: Zed Books.

Naim, C.M. (2004). Urdu Texts and Contexts: The Selected Essays of C.M. Naim. Delhi: Permanent Black.

Nasr, Seyyed Vali Reza (1992). "Students, Islam, and Politics: Islami Jami'at-I Tulaba in Pakistan." Middle East Journal, 46(1), 59-76.

Nasr, Seyyed Vali Reza (1993). "Islamic Opposition to the Islamic State." International Journal of Middle East Studies, 25(2), 261-283.

Nasr, Seyyed Vali Reza (1994). The Vanguard of the Islamic Revolution: The Jama 'at-i Islami of Pakistan. Berkeley: University of California Press.

Nasr, Seyyed Vali Reza (1997). "Islamic Opposition in the Political Process: Lessons from Pakistan." In John L. Esposito (Ed.), Political Islam: Revolution, Radicalism, or Reform? (pp. 135-156). Boulder: Lynne Rienner.

Nasr, Seyyed Vali Reza (2001). Islamic Leviathan: Islam and the Making of State Power. Oxford: Oxford University Press.

Nawaz, Shuja (2008). Pakistan, its Army, and the Wars Within. Oxford: Oxford University Press.

Newburg, Paula (1995). Judging the State: Courts and Constitutional Politics in Pakistan. Cambridge: Cambridge University Press.

Newton, Judith (1994). Starting Over: Feminism and the Politics of Cultural Critique. Ann Arbor: University of Michigan Press.

Noman, Omar (1988). The Political Economy of Pakistan: 1947-85. London: KPI.

O’Connor, Julia S., Orloff, Ann Shola, and Shaver, Sheila (1999). States, Markets, Families: Gender, Liberalism and Social Policy in Australia, Canada, Great Britain and the United States. Cambridge: Cambridge University Press. 
O'Hanlon, Rosalind (1988). "Recovering the Subject: Subaltern Studies and Histories of Resistance in Colonial South Asia." Modern Asian Studies, 22(1), 189-224.

Okin, Susan Moller (1982). "Women and the Making of the Sentimental Family." Philosophy and Public Affairs, 11(1), 65-88.

Oldenburg, Veena Talwar (1984). The Making of Colonial Lucknow: 1856-1877. Princeton: Princeton University Press.

Oldenburg, Veena Talwar (1990). "Lifestyle as Resistance: The Case of the Courtesans of Lucknow, India." Feminist Studies, 16(2), 259-287.

Page, David (1982). Prelude to Partition: The Indian Muslims and the Imperial System of Control, 1920-1932. Delhi: Oxford University Press.

Pandey, Gyanendra (1997). "Community and Violence: Recalling Partition." Economic and Political Weekly, 32(32), 2037-2039, 2041-2045.

Pandey, Gyanendra (2001). Remembering Partition. Cambridge: Cambridge University Press.

Parveen, Tallat (1982). Impact of Zakat on the Rehabilitation of Widows. M.A. Thesis. Department of Social Work, Punjab University, Lahore.

Patel, Rashida (1979). Women and Law in Pakistan. Karachi: Faiza Publishers.

Pateman, Carole (1988). The Sexual Contract. Stanford: Stanford University Press.

Patterson, Steven (2009). The Cult of Imperial Honor in British India. New York: Palgrave Macmillan.

Poovey, Mary (1995). Making a Social Body: British Cultural Formation, 1830-1864. Chicago: University of Chicago Press.

Prakash, Gyan (2000). "Body Politic in Colonial India." In Timothy Mitchell (Ed.), Questions of Modernity. (pp. 189-222). Minneapolis: University of Minnesota Press.

Procacci, Giovanna (1991). "Social Economy and the Government of Poverty." In Graham Burchell, Colin Gordon, and Peter Miller (Eds.), The Foucault Effect: Studies in Governmentality. (pp. 151-168). Chicago: University of Chicago Press.

Rahman, Fazlur (1982). Islam and Modernity: Transformation of an Intellectual Tradition. Chicago: University of Chicago Press. 
Rais, Rasul B. (1989). "Pakistan in 1988: From Command to Conciliation Politics." Asian Survey, 29(2), 199-206.

Richter, William L. (1979). "The Political Dynamics of Islamic Resurgence in Pakistan." Asian Survey, 19(6), 547-557.

Richter, William L. (1982). "Pakistan: a new 'Frontline' State? - I" Muslim, June 5, 1982.

Richter, William L. (1985). "Pakistan in 1985: Testing Time for the New Order." Asian Survey, 26(2), 207-218.

Rizvi, Hasan-Askari (1986). "The Civilianization of Military Rule in Pakistan." Asian Survey, 26(10), 1067-1081.

Rizvi, Hasan-Askari (2000). The Military and Politics in Pakistan, 1947-1997. Lahore: Sang-e-Meel.

Robinson, Francis (1974). Separatism Among Indian Muslims: The Politics of the United Provinces' Muslims, 1860-1923. London: Cambridge University Press.

Rosen, George (1985). Western Economists in Eastern Societies. Baltimore: John Hopkins University Press.

Rouse, Shahnaz (1983). "Systematic Injustices and Inequalities: Maliki and Raiya in a Punjab Village." In Hassan Gardezi and Jamil Rashid (Eds.), Pakistan: The Roots of Dictatorship. (pp. 311-327). London: Zed Press.

Rouse, Shahnaz (1992). "Discourses on Gender in Pakistan: Convergence and Contradiction." In Douglas Allen (Ed.), Religion and Political Conflict in South Asia: India, Pakistan and Sri Lanka. (pp. 87-112). Westport, CT: Greenwood Press.

Rouse, Shahnaz (1997). "(Re)Framing Women and Social Development in Pakistan." In Jacqueline S. Ismael and Enid Hill (Eds.), Social Welfare and Social Development: Asian Experiences. (pp. 151-167). Calgary: Detselig Enterprises Ltd.

Rouse, Shahnaz (1998). "The Outsider(s) Within: Sovereignty and Citizenship in Pakistan." In Patricia Jeffery and Amrita Basu (Eds.), Appropriating Gender: Women's Activism and Politicized Religion in South Asia. (pp. 53-70). New York: Routledge.

Rouse, Shahnaz (2004). Shifting Body Politics: Gender, Nation, State in Pakistan. New Delhi: Women Unlimited. 
Roy, Asim (1993). "The High Politics of India's Partition: The Revisionist Perspective." In Mushirul Hasan (Ed.), India's Partition: Process, Strategy and Mobilization. (pp. 101-131). Delhi: Oxford University Press.

Roy, Olivier (2004). Globalised Islam: the Search for a New Ummah. London: Hurst and Company.

Said Khan, Nighat (1988). Women in Pakistan: A New Era? Lahore: ASR.

Said Khan, Nighat (1994). "Identity, Violence and Women: A Reflection on the Partition of India 1947." In Nighat Said Khan, Rubina Saigol and Afiya Shehrbano Zia (Eds.), Locating the Self: Perspectives on Women and Multiple Identities. (pp. 157-171). Lahore: ASR.

Said Khan, Nighat (1995). "The Political Economy of Pakistan." In Nighat Said Khan and Afiya Shehrbano Zia (Eds.), Unveiling the Issues: Pakistani women's Perspectives on Social, Political and Ideological Issues. (pp. 3-16). Lahore: ASR.

Said Khan, Nighat (2000). "The Women's Movement Revisited: Areas of Concern for the Future." In Suki Ali, Kelly Coate, and Wangui wa Goro (Eds.), Global Feminist Politics: Identities in a Changing World. London: Routledge.

Saigol, Rubina (1993). Education: Critical Perspectives. Lahore: Progressive Publishers.

Saigol, Rubina (1995). Knowledge and Identity: Articulation of Gender in Educational Discourse in Pakistan. Lahore: ASR.

Saigol, Rubina (1997). "The Gendering of Modernity: Nineteenth Century Educational Discourse." In Neelam Hussain, Samiya Mumtaz and Rubina Saigol (Eds.), Engendering the Nation-State. Volume 1. (pp. 155-186). Lahore: Simorgh Women's Resource and Publication Centre.

Saiyid, Dushka (1998). Muslim Women of the British Punjab: From Seclusion to Politics. New York: St. Martin's Press.

Sangari, Kumkum and Vaid, Sudesh (1989). "Recasting Women: An Introduction." In Kumkum Sangari and Sudesh Vaid (Eds.), Recasting Women: Essays in Colonial History. (pp. 1-26). New Delhi: Kali for Women.

Sanyal, Usha (1996). Devotional Islam and Politics in British India: Ahmad Riza Khan Barelwi and his Movement, 1870-1920. Delhi: Oxford University Press.

Sardar Ali, Shaheen, and Arif, Kamran (1994). Blind justice for all? Parallel judicial systems in Pakistan: implications and consequences for human rights._Grabels, France: Women Living Under Muslim Laws. Special Bulletin, October. 
Sarkar, Mahua (2008). Visible Histories, Disappearing Women: Producing Muslim Womanhood in Late Colonial Bengal. Durham, N.C.: Duke University Press.

Sarkar, Sumit (1997). Writing Social History. Delhi: Oxford University Press.

Sarkar, Sumit and Sarkar, Tanika (Eds.), (2008). Women and Social Reform in Modern India: A Reader. Bloomington: Indiana University Press.

Sarkar, Tanika (2001). Hindu Wife, Hindu Nation: Community, Religion and Cultural Nationalism. New Delhi: Permanent Black.

Sassen, Saskia (2003). "Globalization or Denationalization?" Review of International Political Economy, 10(1), 1-22.

Sayeed, Khalid Bin (1960). Pakistan: The Formative Phase. Karachi: Pakistan Publishing House.

Scott, Joan Wallach (2007). The Politics of the Veil. Princeton: Princeton University Press.

Sen, Samita (2004). “'Without his Consent?': Marriage and Women's Migration in Colonial India." International Labor and Working Class History, 65, 77-104.

Shaheed, Farida (1989). "Purdah and Poverty in Pakistan." In Haleh Afshar and Bina Agarwal (Eds.), Women, Poverty and Ideology in Asia. (pp. 17-42). London: Macmillan.

Shaheed, Farida (1990). "The Pathan-Muhajir Conflicts, 1985-6: A National Perspective." In Veena Das (Ed.), Communities, Riots and Survivors in South Asia. (pp. 194-214). Delhi: Oxford University Press.

Shaheed, Farida (1998). "The Other Side of the Discourse: Women's Experiences of Identity, Religion, and Activism in Pakistan." In Patricia Jeffery and Amrita Basu (Eds.), Appropriating Gender: Women's Activism and Politicized Religion in South Asia. (pp. 143-164). New York: Routledge.

Shaheed, Farida and Mumtaz, Khawar (1989). "Veils of Tears." Far Eastern Economic Review, 145(39), 128-29.

Shaheed, Farida and Mumtaz, Khawar (1990). "The Rise of the Religious Right and its Impact on Women." South Asia Bulletin, 10(2), 9-17.

Shaikh, Farzana (1989). Community and Consensus in Islam: Muslim Representation in Colonial India, 1860-1947. Cambridge: Cambridge University Press. 
Sher, Ferida (1996). "Film." In Maha Malik and Neelam Hussain (Eds.), Re-inventing

Women: Representation of Women in the Media during the Zia Years. (pp. 43-65).

Lahore: Simorgh Women's Resource and Publication Centre.

Siddiqa, Ayesha (2007). Military Inc.: Inside Pakistan's Military Economy. Karachi, Oxford University Press.

The Simorgh Collective and Shazreh Hussein (1990). Rape in Pakistan. Lahore: Simorgh Women's Resource and Publication Centre.

Sinha, Mrinalini (2000). "Refashioning Mother India: Feminism and Nationalism in LateColonial India." Feminist Studies, 26(3), 623-644.

Sinha, Mrinalini (2004). "Gender and Nation." In Bonnie G. Smith (Ed.), Women's History in Global Perspective. Volume 1. (pp. 229-274). Urbana: University of Illinois Press.

Steinmetz, George (1993). Regulating the Social: The Welfare State and Local Politics in Imperial Germany. Princeton: Princeton University Press.

Stoler, Ann Laura (1995). Race and the Education of Desire: Foucault's History of Sexuality and the Colonial Order of Things. Durham, N.C.: Duke University Press.

Stoler, Ann Laura and Frederick Cooper (1997). "Between Metropole and Colony: Rethinking a Research Agenda." In Frederick Cooper and Ann Laura Stoler (Eds.), Tensions of Empire: Colonial Cultures in a Bourgeois World. (pp. 1-56). Berkeley: University of California Press.

Sullivan, Zohreh T. (1998). "Eluding the Feminist, Overthrowing the Modern?

Transformations in Twentieth Century Iran." In Lila Abu-Lughod (Ed.), Remaking Women: Feminism and Modernity in the Middle East. (pp. 215-242). Princeton: Princeton University Press.

Syed, Anwar H. (1992). The Discourse and Politics of Zulfikar Ali Bhutto. London: Macmillan.

Tahir-Kheli (1982). The United States and Pakistan: The Evolution of an Influence Relationship. New York: Praeger.

Talbot, Ian (1988). Punjab and the Raj, 1849-1947. New Delhi: Manohar.

Talbot, Ian (1998). Pakistan: A Modern History. New York: St. Martin's Press.

Talbot, Ian and Singh, Gurharpal (2009). The Partition of India. Cambridge: Cambridge University Press. 
Valverde, Mariana (1991). The Age of Light, Soap, and Water: Moral Reform in English Canada, 1885-1925. Toronto: McClelland and Stewart.

Verkaaik, Oskar (2004). Migrants and Militants: Fun and Urban Violence in Pakistan. Princeton: Princeton University Press.

Viswanathan, Gauri (1989). Masks of Conquest: Literary Study and British Rule in India. New York: Columbia University Press.

Voll, John Obert (1994). Islam, Continuity and Change in the Modern World. 2nd ed. Syracuse: Syracuse University Press.

Von Vorys (1965). Political Development in Pakistan. Princeton: Princeton University Press.

Walsh, Judith (2004). Domesticity in Colonial India: What Women Learned when Men Gave them Advice. Lanham, MD: Rowman and Littlefield.

Washbrook, D.A. (1981). "Law, State and Agrarian Society in Colonial India." Modern Asian Studies, 15(3), 649-721.

Woodsmall, Ruth Francis (1960). Women and the New East. Washington, D.C.: Middle East Institute.

Zaman, Muhammad, Qasim (1998). "Sectarianism in Pakistan: the Radicalization of Shi'i and Sunni Identities." Modern Asian Studies, 32(3), 689-716.

Zaman, Muhammad, Qasim (2002). The Ulama in Contemporary Islam: Custodians of Change. Princeton: Princeton University Press.

Zamindar, Vazira Fazila-Yacoobali (2007). The Long Partition and the Making of Modern South Asia: Refugees, Boundaries, Histories. New York: Columbia University Press.

Zia, Afiya Shehrbano (1994). Sex Crime in the Islamic Context. Lahore: ASR.

Ziring, Lawrence (1971). The Ayub Khan Era: Politics in Pakistan, 1985-1969. Syracuse: Syracuse University Press.

Ziring, Lawrence (1988). "Public Policy Dilemmas and Pakistan's Nationality Problem: The Legacy of Zia ul-Haq." Asian Survey, 28(8), 795-812. 
$\underline{\text { Appendix A }}$

Interview Participants' Main Activist or Professional Affiliations in Addition to the Women's Action Forum (WAF)

\begin{tabular}{|l|l|}
\hline Interview 1 & Simorgh, Lahore \\
\hline Interview 2 & Tehrik-i-Khawateen, Lahore \\
\hline Interview 3 & Simorgh, Lahore \\
\hline Interview 4 & ASR, Lahore \\
\hline Interview 5 & Simorgh, Lahore \\
\hline Interview 6 & Human Rights Commission of Pakistan, Aurat Foundation, Islamabad \\
\hline Interview 7 & Human Rights Commission of Pakistan, ASR, Karachi \\
\hline Interview 8 & Punjab Women Lawyers Association, Lahore \\
\hline Interview 9 & Shirkat Gah, Lahore \\
\hline Interview 10 & Educator, Lahore \\
\hline Interview 11 & Shirkat Gah, Karachi \\
\hline Interview 12 & Punjab Women Lawyers' Association, Lahore \\
\hline Interview 13 & Tehrik-e-Istaqlal at time, now Muslim League, Lahore \\
\hline Interview 14 & All Pakistan Women's Association (APWA), Lahore \\
\hline Interview 15 & Democratic Women's Association (DWA), Lahore \\
\hline Interview 16 & Working Women's Association, Lahore \\
\hline Interview 17 & Trade union organizer, Lahore \\
\hline Interview 18 & $\begin{array}{l}\text { Business and Professional Women's Club, Pakistan Anjuman Khawateen } \\
\text { Islam, Islamabad }\end{array}$ \\
\hline Interview 19 & Muslim League, Lahore \\
\hline Interview20 & Tehrik-i-Khawateen, Lahore \\
\hline
\end{tabular}

